Journal of the Scientific Agricultural Society of Finland

Vol. 45: $325-4601973$

Maataloustieteellinen Aikakauskirja

\title{
KAINUULAISEN UUDISTILAN EDULLISIN SUURUUS JA TUOTANTOSUUNTA
}

Summary: On the optimum size and combination of agricultural and forestal activities of a typical North-East Finland pioneer farm

K. U. PIHKALA ja TAPANI LASOLA

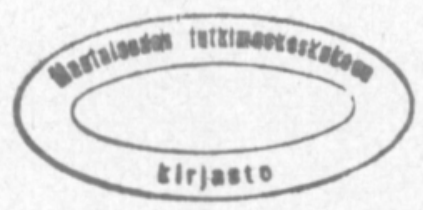




\section{Esipuhe}

Tämä tutkimus muodostaa osan laajemmasta tutkimusohjelmasta, jonka tarkoitus on ollut selvitellä maan maa- ja metsätaloudellisen käytön suhteellista edullisuutta vastikään raivausten kohteena olleilla mailla eräissä Suomen osissa. Arvosteltaessa maan käytön edullisuutta meillä yleisimmän talousyksikön, perheviljelmän puitteissa, erilaisten maa- ja metsätaloudellisten tuotantomuotojen toisiaan täydentävä vaikutus osoittautuu tärkeäksi huomioonotetțavaksi tekijäksi. Sekä maa- että metsätaloudellisesta käytöstä saadaan edullisin tulos vain mahdollisten tuotantomuotojen edullisimman yhdistelyn tapahtuessa. Tämänvuoksi on yhden osatutkimuksen aiheeksi valittu erään päätutkimuksen piiriin kuuluneen tyypillisiä pohjois-suomalaisia olosuhteita edustavan tutkimusalueen uudistilan edullisimman suuruuden ja tuotantosuunnan määrittäminen.

Päätutkimuksen suunnittelusta ja järjestämisestä vastasi tutkijaryhmä, johon allekirjoittaneiden lisäksi kuuluivat professori Viljo Holopainen, MTT Matti Keltikangas ja MMK, varatuom. Paavo Väisänen. Viimeksimainittu on organisoinut tietojen hankinnan tutkimusalueella. Asutushallitus, Kajaanin metsänhoitolautakunta ja Kajaanin osuusmeijeri ovat antaneet tutkimusta varten varsin hyödyllisiä tietoja. Erityisesti on syytä kiittää myöskin tutkimustilojen viljelijöitä, jotka usean vuoden aikana ovat uhranneet aikaansa ei aivan helposti saatavissa olevien tietojen antamiseksi.

Tutkimuksen metodin kehittämisessä, laskelmissa ja tietokonekäsittelyssä ovat arvokasta apua antaneet nyk. apulaisprofessori Lauri Kettunen, FK Jorma Pihkala ja FM Harri Wetterstrand. Tutkimuksen painokuntoon saattamisessa on avustanut agronomi Marja-Terttu Fäldén.

Tutkimuksen rahoittamisessa on Yhdysvaltain markkatilirahastosta (PL 480) ja Yrjö Jahnssonin säätiöltä saaduilla apurahoilla ollut merkittävä osuus. Esitämme parhaat kiitoksemme siitä, samoinkuin Maataloustieteelliselle Seuralle siitä, että se on ottanut tämän tutkimuksen julkaisusarjaansa.

Haluamme tällä tutkimuksella, jonka valmistuminen valitettavasti on monista syistä kovin paljon viivästynyt, omalta osaltamme osoittaa kunnioitustamme niille tuhansille kylmien uudistilojen raivaajille, jotka sodan jälkeen ovat antaneet panoksensa maan jälleenrakentamiseen. 


\section{SISÄLLYSLUETTELO}

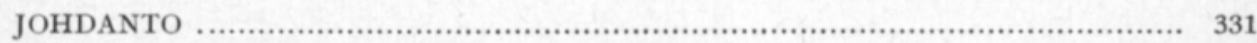

TUTKIMUKSEN ONGELMAKENTTÅ JA TEHTÅVÅ ……........................... 334

LP-MENETELMÅ MAATILATALOUDELLISESSA SUUNNITTELUSSA …............ 338

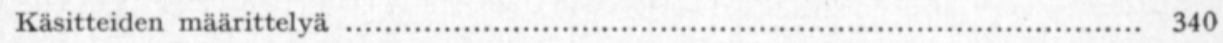

YLEISIÅ TIETOJA TUTKIMUSALUEESTA …............................................... 343

Eri viljelykasvien viljely ....................................................................... 345

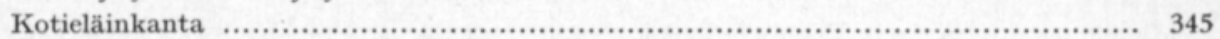

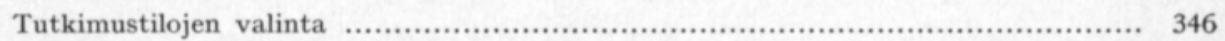

Tutkimustilojen pellot ja viljelyskelpoinen maa …..................................... 354

Tutkimustilojen hehtaarisadot vv. 1959-64 sekä väkilannoitteiden ja maatalouskalkin

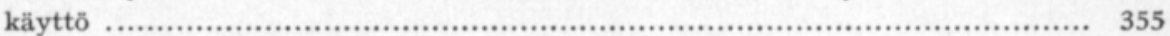

TUTKIMUSTILOJEN RAKENTEELLISTA TARKASTELUA …..................... 357

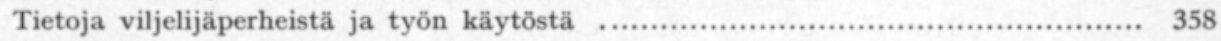

Hevos- ja traktorityo̊ tutkimustiloilla ........................................................ 359

Maidontuotantoa koskevat tiedot …....................................................... 359

Metsätaloussuunnitelmat ja niiden perusteet …............................................ 361

Aikaisempia laskelmia tutkimustilojen taloudellisista tuloksista .......................... 363

MAATILATALOUDEN TUOTANTOSUUNNAN PERUSTEITA …...................... 366

Maan lannoitustarve ja sadot ............................................................... 366

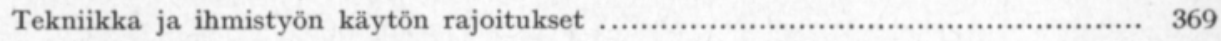

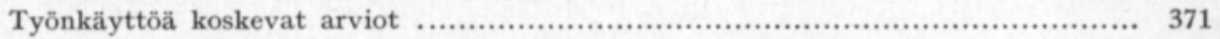

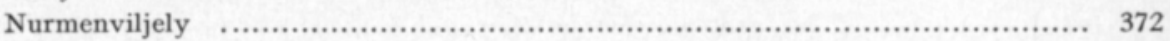

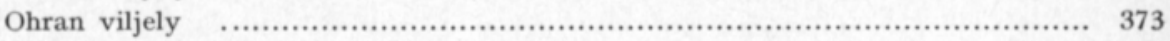

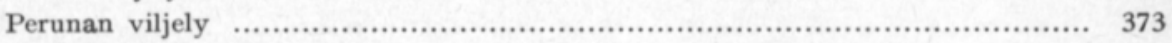

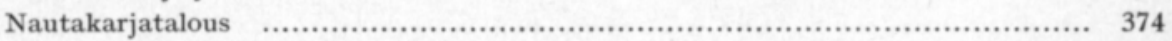

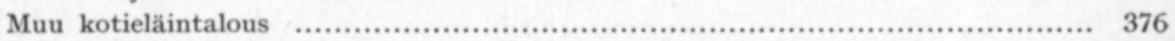

Karjanlannan kuljetus ja levitys ........................................................ 376

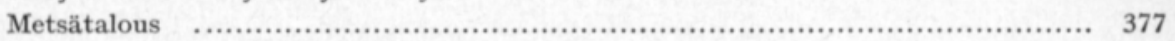

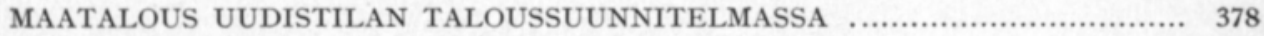

Hevos- ja traktorityön kustannukset ......................................................... 378

Erinäisten laitteiden ja koneiden kustannuksista ......................................... 379

Uudisraivauskustannukset ..................................................................... 380

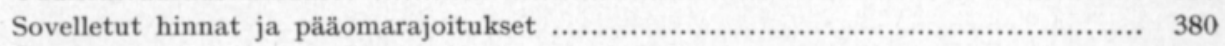

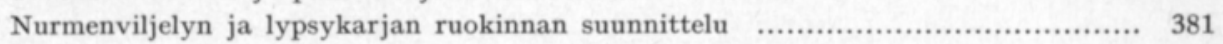

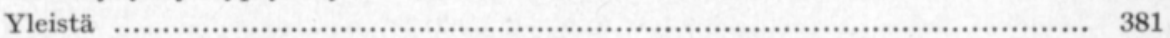

Laskelmien perustana olevat lannoituskokeet ........................................... 382

Kokeissa saavutetut rehusadot ja niiden laatu ........................................ 384

Nurmenviljelyn vaihtoehtoisten tuotantoprosessien vertailu ........................ 386

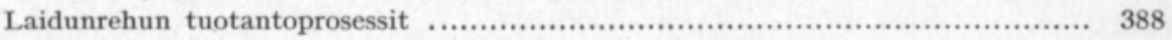

Lypsykarjan ruokintaa koskevat laskelmat …....................................... 390 


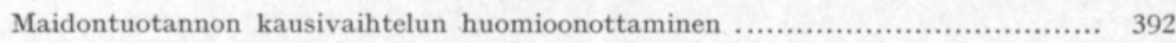

Ensimmäinen LP-laskelma. Koelaskelma (A) ..................................... 393

Kuukausittaisiin keskilypsyihin perustuva ruokintasuunnitelma ................... 396

Tietokoneella suoritetut koelaskelmat ............................................... 397

Koelaskelma (B). Säilörehun täyttävyysluvun vaikutus ruokintasuunnitelmaan . 398

Koelaskelma (C). Maidontuotantokäyrän muodon ja laidunkauden ajankohdan

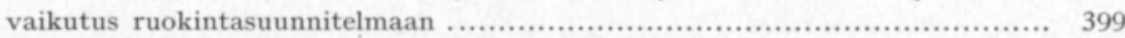

Uudistilan tuotantosuunnitelmassa sovellettavat luvut f........................... 400

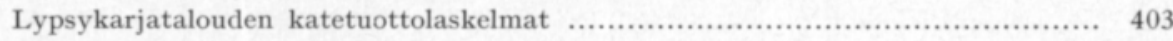

Tuotantoprosessit naudanlihan tuotannossa . ........................................... 404

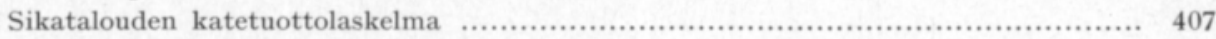

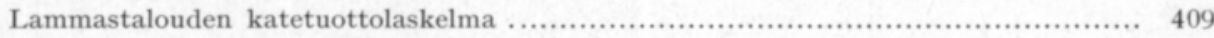

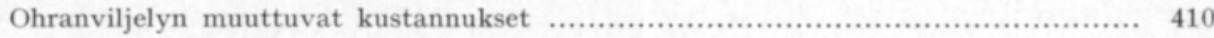

Perunanviljelyn katetuotto ja muuttuvat kustannukset .............................. 413

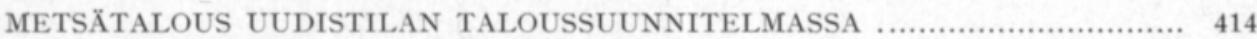

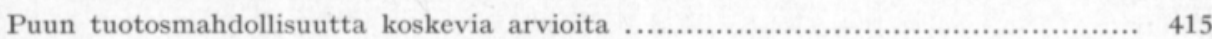

Kasvatushakkuiden tuotos ja tulovaikutus ............................................... 417

Puutavarasta maksetut hinnat ja hankintatulot ...................................... 419

Puutavaran kantohinnat ja hankintapalkat ........................................ 421

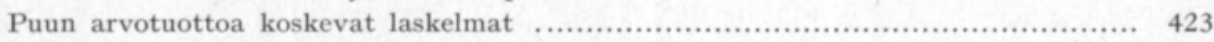

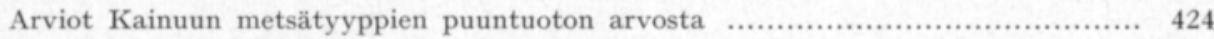

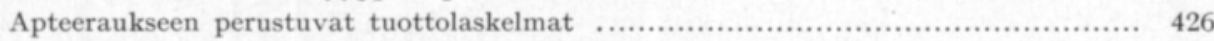

Harvennushakkuiden tulovaikutusta koskevia arvioita ............................... 428

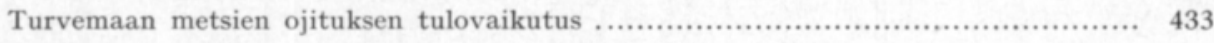

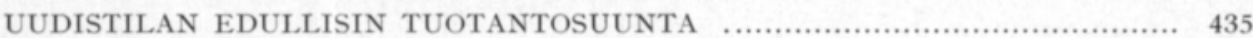

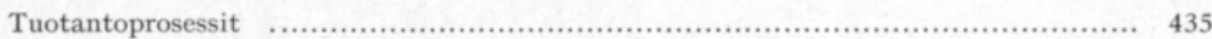

Ensimmäiset aggregoiduilla malleilla tehdyt tuotantosuunnitelmat ...................... 438

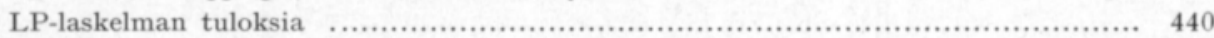

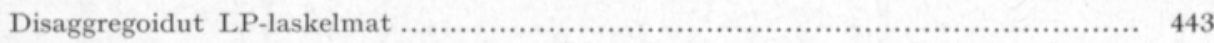

Muuttuvia lypsykarjan työnmenekkilukuja soveltaen tehdyt laskelmat ................. 445

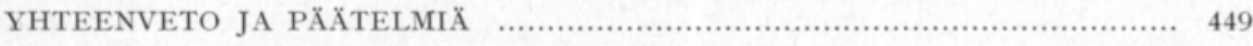

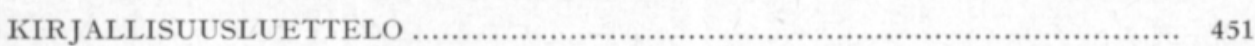

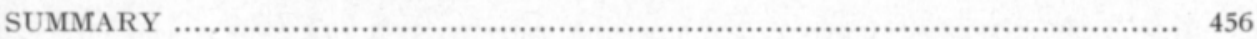

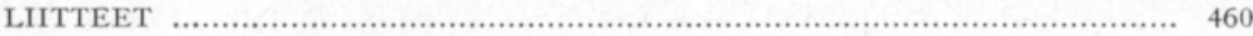


Pihkala, K. U. and Lasola, T. 1973. On the optimum size and combination of agricultural and forestal activities of a typical North-East Finland pioneer farm. J. Scient. Agric. Soc. Finl. 45: 325-460.

\begin{abstract}
In this study an attempt is made to develop an optimum production plan for a family farm representing actual conditions of post-war settlement in NorthEast Finland. The proportional use of land and other rescources for farming and forestry is determined in the planning process in which the Linear Programming method is applied. The cultivation of timothy grass has been regarded as the main basis for farming, and a combined fertilizing and feeding plan is made, using available technical and economic information relating to the region. Two levels of techniques and different alternatives in the intensity level have been taken as a basis for calculations both in agriculture and in forestry; the economics of scale is taken into account in some alternatives of milk production. The optimum plan was regarded as the one giving a maximum gross margin to family labour and capital, but an interesting problem arises from the fact that some activities, especially in forestry, yield an income only in the distant future.

According to the results of the study, a gross margin of 11700 FM may be obtained using 11 ha land for agriculture and 80 ha mineral soil as forest, with horse driven techniques and 10 cows, while the corresponding figures could be $16100,22,80$ and 17 with tractor driven techniques. Limitations in the use of forest land and capital have some influence on the results, which also are influenced by the price level of the period of study (1959-63).
\end{abstract}

\title{
Johdanto
}

Sodanjälkeisen laajan asutusohjelman yhteydessä perustettiin, etenkin lähinnä rintamamiesten asuttamista silmälläpitäen, suuri joukko uudistiloja, joiden viljelykset oli kokonaan raivattava luonnontilassa oleville puuta tuottaville metsämaille tai osittain myös joutomaihin luettaville puuttomille soille. Tällaisten uudistilojen viljelijöiksi halukkaat saivat erikoisetunaan muihin asutettaviin verrattuna ns, uudistilojen perustamispalkkion, jonka määrä vaihteli maan eri osissa ollen kuitenkin suurin Pohjois-Suomessa. Asutettavien piirissä näitä tiloja alettiin nimittää »kylmiksi» tiloiksi, ja ilmeisesti vaadittiinkin näiden tilojen vastaanottajilta tavallista suurempaa rohkeutta ja itseluottamusta, heidän ryhtyessään rakentamaan asuntojaan ja karjasuojiaan sekä levittämään viljelyksiään synkkään korpeen aikana, jona jo jossain määrin oli totuttu helpompaan elintapaan. He ehkä tiesivät, että Suo- 
men asuttaminen on vanhastaan edennyt samoja latuja, ja että valtion tuki avustusten ja lainojen muodossa tällä kertaa oli suurempi kuin koskaan aikaisemmin, mutta myöskin sen, että maanviljelijän ansiomahdollisuudet ovat vaatimattomia siihen verrattuna mitä voidaan ansaita työpalkkoina teollisuudessa ja yleisissä töissä. Ehkäpä se kuitenkin monelle oli ainoa näköpiirissà oleva vaihtoehto oman ja vastaperustetun kodin toimeentulon turvaamiseksi.

Asutettavien kuin myös kansantalouden kannalta on niillä suunnitelmilla, joita asuttamisen yleistä toteuttamista ja myöskin kutakin yksityistä tapausta varten aikanaan laadittiin, tietenkin ollut varsin tärkeä merkitys. Nämä suunnitelmat oli niitä tehtäessä vallinneissa olosuhteissa laadittava kiireellisesti ja vailla sellaisia perustietoja, joita yksityistaloudellisissa suunnitelmissa yleensä tarvitaan. Käytännölliseen kokemukseen perustuva harkinta on saanut korvata sitä, mitä olisi voitu saavuttaa kirjanpitotuloksiin perustuvien kustannuslaskelmien kautta. Asutuslakien suunnitteluun ja toteuttamiseen eri portaissa osallistuneiden toimikuntien maanviljelijäjäsenten panos on saattanut olla erityisen tarpeellinen. Mitään perusteellista kriittistä arviointia asutussuunnitelmista ei kuitenkaan edes jälkeenpäin ole suoritettu. Maatilataloudessa asutussuunnitelmien laatimisen jälkeen tapahtunut voimakas tekninen kehitys on sitä paitsi muuttanut taloudellisia edellytyksiä, joten aikanaan hyvätkään suunnitelmat eivät ehkä enää vastaa nykyisen talouselämän vaatimuksia.

Nykyisin on verrațen yleisesti levinnyt se käsitys, etțä Pohjois-Suomen uudistilojen perustamiseen tehdyt investoinnit ovat olleet kansantaloudelliselta kannalta virheellisiä, koska maatalousțuotannon kannattavuusedellytykset pohjoisessa ovat heikkoja ja siellä saatu tuotannonlisäys on vain epäedullisesti markkinoitavissa. Mikäli on kysymys virheinvestoinneista - joita kansantaloudessamme on runsaasti tapahtunut muillakin suunnilla - niistä olisi tietenkin otettava oppia vastaisuudessa. Jo tehtyjä investointeja olisi kuitenkin tarpeellisten poistojen jälkeen käytettävä niin edullisesti kuin olevissa oloissa on mahdollista, muistaen että monet tuotantolaitoksistamme ovat voineet jatkuvasti toimia ja kehittää tuotantoaan, vaikka ensimmäiset varainsijoittajat ovatkin menettäneet varansa ja toiset ovat jatkaneet toimintaa tuntuvien pääoman poistojen jälkeen.

Pohjois-Suomen luonnonvaroista ovat metsät tärkeimpiä, ja metsätalouden tuotteiden markkinointimahdollisuuksia pidetään nykyisin taattuina. Suomalaisessa maatilataloudessa täydentävät maatalous ja metsätalous perinteellisesti toisiaan. Yhteistä työvoimaa, vetoeläimiä ja koneita voidaan edullisesti käyttää, koska metsätyöt eivät ole samalla tavalla sidottuja vuodenaikoihin ja säihin kuin huomattava osa maatalouden töistä, nim. peltoviljelytyöt. Maatalous voi puolestaan käyttää hyväksi metsätaloudesta saatavia, vähäarvoisia tai arvottomia sivutuotteita, kuten pienpuuta ja harvennusjätteitä. Ovatko nämä edut niin suuria, että uudistilojen perustaminen alueen metsävarojen hyväksikäytön kannalta olisi toivottavaa siinäkin tapauksessa, että niiden maataloutta ei voitaisi harjoittaa kannattavalla tavalla, on kysymys, jota on syytä tutkia. Tämä on tarpeellista senkin takia, että viime aikoina on ehdotettu toisenlaisiakin ratkaisuja, nim. metsätyöhön erikoistuneiden työntekijäin muodostamia asuntokyliä. 
Uudistiloilla suoritetut pellonraivaukset vähentävät monissa tapauksissa kasvullisen metsän alaa. Vaikka Pohjois-Suomessa raivaukset ensisijassa suuntautuvatkin huonokasvuisille tai kokonaan tuottamattomille soille, ei tätäkään tosiasiaa voida kokonaan sivuuttaa tarkasteltaessa uudistilojen perustamisen taloudellisia vaikutuksia.

Liittyen laajempaan tutkimusohjelmaan, jonka tarkoituksena on tutkia maan maataloudellisen ja metsätaloudellisen käytön suhteellista edullisuutta, tässä osatutkimuksessa koetetaan selvittää, millaisia yksityistaloudellisia tuloksia Kainuun uudistiloilla saavutetaan tai tarkoituksenmukaisella järjestelyllä todennäköisesti voitaisiin saavuttaa maataloudellisen ja metsätaloudellisen tuotannon sopivalla yhdistelyllä perheviljelmän puitteissa. 


\section{Tutkimuksen ongelmakenttä ja tehtävä}

Täydellä omistusoikeudella hoidettu perheviljelmä on näihin saakka osoittanut elinvoimaisuutensa sellaisissakin olosuhteissa, joissa maavarat ovat olleet verraten rajoitettuja ja tilojen suuruus siten pienempi kuin yleisesti katsotaan edullisimmaksi. Maareformit, joissa maa on annettu viljelijöiden omistukseen, ovat alkuvaikeuksien jälkeen yleensä johtaneet kansantaloudellisen kasvun kannalta suotuisaan kehitykseen. RAUP (1967, p. 272-278) on eräässä kirjoituksessaan analysoinut syitä siihen, että tälle pohjalle rakennetut suhteellisen pienetkin perheyritykset ovat pystyneet käyttämään tehokkaasti tärkeintä tuotantovaraansa, omaa työvoimaansa ja muodostamaan uutta pääomaa. Maatalouden investoinnit kypsyvät pitkien aikaperiodien kuluessa; ne tapahtuvat usein hitaiden biologisten kasvuilmiöiden muodossa. Yrittäjät, jotka tuntevat varmuutta omistuksen jatkumisesta myöskin tulevan sukupolven aikana, ovat valmiita käyttämään liian harvoista tarjona olevista tuotantomahdollisuuksista johtuvaa pakollista vapaa-aikaa tai maataloustuotannon biologisesta luonteesta johtuvaa kausiluontoista vapaa-aikaa suorittaakseen usein vähäpätöiseltäkin tuntuvia tehtäviä, joilla jatkuvasti uusiutuvina yrityksen tulevaisuudelle voi olla suuri merkitys.

Suomalaisessa asutustoiminnassa on rakennus- ja raivausinvestoinnit perinteellisesti suurimmalta osalta jätetty asutettavien omatoimisuuden varaan, joskin lainoja ja avustuksia myönnettäessä on edellytetty tiettyjen suunnitelmien ja normien noudattamista. Uudistilojen perustajat ovat siis käyttäneet omaa ja perheensä työvoimaa aluksi lähinnä tuotantopohjan luomiseen, myöhemmin sen laajentamiseen ja varsinaiseen tuotantoon. Viljelijäperheen käytettävissä oleva työvoima, joka vaihtelee ikä- ja perhesuhteiden mukaan, asettaa rajoituksia sekä tuotantosuuntaan että investointeihin, mutta edellämainitut biologiset tosiasiat vaativat tämän ohella huomioonottamista.

1930-luvulta lähtien on virallisessa asutustoiminnassamme tapahtunut muutos, joka koskee asutustilojen mitoitusperiaatetta. Kun vuosisadan alkupuolella asutustiloille pyrittiin varaamaan metsämaata lähinnä kotitarvepuun tarpeen tyydyttämiseksi, on myöhemmin omaksuttu ns. tukimetsäperiaate, jonka mukaan metsää on annettava niin paljon, että siitä »kotitarvepuun ohella voidaan saada kohtuullinen määrä myyntikelpoista puuta». Tätä periaatetta on voitu perustella kansantaloudellisilla näkökohdilla. Jos asutustilan koko puuntuotos käytetään oman talouden tarpeisiin, saattaa tuotoksen arvokkain osa joutua tuhlaavan käytön esineeksi. Periaatteen soveltaminen 
edellyttää talouden erilaisten puutavaralajien tarpeen määrittämistä ja käytettävissä olevan metsän puuntuotoksen rakenteen tuntemista.

1960-luvulta lähtien asutustoiminnan painopiste on asetettu lähinnä metsämaan muodossa annettavan lisämaan jakamiseen entisille asutustiloille. Metsätaloudesta saatavan rahatulon tarpeellisuus maataloudesta saatavan tulon täydentämiseksi on tässä yhteydessä tullut yhä enemmän etualalle. Metsävarojen niukkuus asettaa kuitenkin kaikkialla katon tämänluontoiselle asutustoiminnalle. Toisaalta on syytä myöskin selvitellä, miten laajaa metsätaloutta viljelijät pystyvät maataloustoimintansa ohella harjoittamaan suorittaessaan sekä hoito- että hankintatyöt omalla ja perheensä työvoimalla.

Tässä tutkimuksessa on vuosina 1959-64 tutkittavalta alueelta kerättyyn havaintoaineistoon nojautuen pyritty laatimaan mahdollisimman tarkoituksenmukainen taloussuunnitelma uudismaalle perustettavalle perheviljelmälle, jolle maata ajatellaan annettavaksi niin paljon, että viljelmällä oleva työvoima voidaan mahdollisimman tehokkaasti käyttää hyväksi. Perheviljelmä käsitetään tässä ahtaamman vaihtoehdon mukaan, jolloin sen katsotaan antavan työtä ja toimeentulon yhdelle työkykyiselle avioparille ja heidän alaikäisille lapsilleen. Laajemman käsitteen mukainen perheviljelmä, jolla kaksi peräkkäisiin sukupolviin kuuluvaa perhettä hankkii itselleen toimeentulon, on tässä tarkastelussa sivuutettu.

Tutkimuksessa pyritään aluksi antamaan kuva niistä olosuhteista, joissa maatilataloutta harjoitetaan eräällä Kainuun metsäseudulla olevalla uudisraivausalueella. Tätä seuraavissa laskelmissa pyritään mitoittamaan ja suunnittelemaan uudistilan talous sițen, että perheen työlle ja kiinteistöön sijoitetulle pääomalle saadaan mahdollisimman korkea katetuotto. Kun maavarat ovat tutkimusalueella suhteellisen niukat, on uudistilan kokonaispintaalalle asetettu yläraja. Tämä on laskettu jakamalla alueen kokonaisala, josta joutomaa on vähennetty, maatalousväestöön kuuluvien perheiden luvulla. Rajoituksia on täytynyt asettaa myös erikseen kivennäis- ja erikseen turvemaan alan osalta. Edellisessä on katto asetettu 80 ha:n, jälkimmäisessä 125 ha:n kohdalle.

Tutkittaessa Pohjois-Suomen maataloudellisia mahdollisuuksia on erityisesti kiinnitettävä huomiota turvemaiden hyväksikäyttöön. Näillä mailla ovat timoteivaltaisista nurmista korjattu heinä ja säilörehu ainoat luotettavat satotuotteet, ja laskelmissa on syytä tutkia, miten niiden varaan voidaan rakentaa mahdollisimman kannattava mataloustuotanto. Turvemailla voi rehuksi viljeltävä naattinauris tulla kysymykseen heinän ohella, ja kivennåismailla voidaan viljellä perunaa ja ohraa, molempia osaksi suoranaiseen kulutukseen, osaksi rehuksi, jolloin kuitenkin on laskelmissa otettava huomioon verraten tiheään sattuvista katovuosista johtuva riski.

Kun timoteinurmien sadon hyväksikäyttö voi perustua lähinnä maidon ja naudan- tai lampaanlihan tuotantoon, on tässä tutkimuksessa tärkeä sija näitä tuotannonhaaroja koskevilla laskelmilla. Myös sikataloutta koskevat laskelmat ovat sikäli tärkeitä, että tämä tuotannonala on eräs merkittävä vaihtoehto maidosta saatavien sivutuotteiden jalostamisessa. Tässä tutkimuksessa edellytetään, että sikatalouden enimmäislaajuus määräytyy tilan maidontuotannon perusteella. 
Viljan viljelyn luonnolliset edellytykset ovat Pohjois-Suomessa suhteellisesti epäedulliset. Vain ohra antaa useimpina vuosina tyydyttävästi tuleentuneen sadon. Jos sen epävarmuus otetaan laskelmissa huomioon, voidaan tämä lähinnä rehuviljana käytettävä tuote sisällyttää tuotantosuunnitelmiin. Myös kauraa ja ruista on tässä tutkimuksessa tarkastellulla alueella pienessä määrin viljelty, mutta etenkin edellisen viljely on yhä vähentynyt. Niitä ei tässä tutkimuksessa oteta tuotantosuunnitelmaan.

Perunan viljely on Pohjois-Suomessa aina Lapin perukoille yleistä, mutta yleensä vain pienillä aloilla, jotka esim. vaaramaiden kivennäismaille sijoitettuina antavat jopa valtakunnan korkeimpia hehtaarisatoja. Tunnetusti ovat näiden alueiden perunanviljelykset säilyneet suhteellisesti vapaina virus- ja muiltakin kasvitaudeilta, joten on toisinaan puhuttu myös markkinoita varten suunnattavasta siemenperunan tuotannosta. Hallaisina vuosina ja erityisesti alavilla mailla perunasato kuitenkin usein täysin epäonnistuu. Kun viljelijäperheet voivat hinnoitella kotitarpeeksi käyttämänsä perunan vähittäishintaan, voidaan katsoa, että perunanviljely omaa tarvetta varten kannattaa aina sisällyttää tuotantosuunnitelmaan. Perunanviljelyssä on varauduttava siihen, että osa sadosta joko heikon laadun tai vuosittaisten suurten satovaihtelujen takia joudutaan käyttämään rehuksi. Perunan mahdollinen viljely yksinomaan rehuksi otetaan mahdollisena vaihtoehtona tuotantosuunnitelmaan.

Naattinauris on toistaiseksi verrattain vähän viljelty rehukasvi, jonka rehuyksikkösato on samaa suuruusluokkaa kuin perunan ja viljelyvarmuus pohjoisessa ehkä parempi. Sen valkuaispitoisuus on korkeampi, mutta täyttävyys epäedullisempi kuin perunan. Kun tietoja sen viljelystä on niukalti tutkimusalueelta, ja kun perunan viljely rehuksi edellytyksiltään lienee saman laatuinen, ei naattinaurista oteta lukuun erillisenä vaihtoehtona.

Kanataloutta ei tuotantosuunnitelmissa oteta lukuun, koska se vain hyvin vähäisessä määrässä voisi perustua alueen luonnollisiin edellytyksiin ja sen maavarojen käyttöön.

Hevosten kasvatuksella ja pidolla olisi sitävastoin alueen olosuhteissa luonnon suomat edellytykset. Timoteiheinä on hyvin sopiva hevosten perusrehu, ja joskaan alueella ei juuri viljellä kauraa, lienee välttämätön väkirehuruokinta osaksi alueenkin tuotteilla suhteellisen helposti järjestettävissä. Hevonen on perinteellisesti metsätyömiehen tehokas apulainen, ja monien mielestä jatkuvasti metsässä tarpeellinen. Jo tutkimusvuosina traktoritekniikka oli tosin ihmisen työn tehokkuutta peltoviljelyssä ja ehkä osaksi metsässäkin lisäävänä, mutta myöskin muotivirtauksena valtaamassa alaa hevostekniikalta, jolla ei ollut tukenaan samanlaisia subventioita kuin muulla kotieläintuotannolla. Kuitenkin on vaihtoehto hevonen otettu mukaan senkin vuoksi, että traktori- ja hevostekniikan perusteella saatujen tulosten vertailu on sellaisenaan mielenkiintoinen. Hevoskasvatusta ei sensijaan ole otettu vaihtoehdoksi, koska siitä pientilalla voidaan saada korkeintaan satunnaisia lisätuloja.

Laskelmissa on siis edellytetty vaihtoehtoina joko hevosen tai traktorin käyttöön perustuva tekniikka. Molemmissa tapauksissa edellytetään hankituiksi tärkeimmät tarpeelliset työkoneet. Traktorin oletetaan olevan diesel- 
käyttöinen, vähintään 35 hv:n moottorilla varustettu. Eräitä harvemmin tarvittavia koneita, kuten niittosilppureita, leikkuupuimureita ja vasaramyllyjä on edellytetty, sikäli kuin niitä tuotannossa tarvitaan, käytettäviksi yhteisinä.

Metsätalouden liittyminen maatalouden tuotantosuunnitelmaan aiheuttaa kokonaistalouden optimointiin pyrittäessä monia ongelmia. Eräs niistä on siinä, että hakkuiden määrillä ja suorittamistavoilla on vaikutuksensa tulevaan metsän tuottoon. Hakkuusuunnitteiden määrittäminen vaatii puustojen ja niiden kasvuedellytysten tarkkaa tuntemusta ja metsätaloudellisen teorian hallintaa. Kun puun tuotantokausi on erityisesti Pohjois-Suomessa tavattoman pitkä, on parhaimmillakin edellytyksillä suoritetussa suunnittelussa suuri epäonnistumisen vaara, sikäli kuin suunnittelun perusteella toteutettujen toimenpiteiden tuloksia arvostellaan jälkeenpäin. Hintasuhteiden ja tekniikan muutokset saattavat tehdä tyhjäksi tai kokonaan muuttaa kunkin ajankohdan olosuhteiden perusteella tehtyjen laskelmien tulokset.

Samankin metsäalan metsätaloussuunnitelma saattaa edellyttää erilaisia hakkuita ja hakkuutuloja riippuen puustojen laadusta ja ikäluokkarakenteesta. Kun nämä tarkoituksenmukaisesti järjestetyssä metsätaloudessa saattavat muuttua, on metsätaloutta harjoittavan maatilatalouden edullisin taloussuunnitelma ajan kuluessa yleensä muuttuva jopa silloinkin kun hintasuhteet pysyvät ennallaan. Eri asia on tietysti, että myös hintasuhteiden ja tekniikan muutokset vaikuttavat taloussuunnitelmaan kaikilta osiltaan.

Maatilan taloussunnitelma olisi pyrittävä tavalla tai toisella kehittämään pitkän ajan taloussuunnitelmaksi. Mutta toisaalta pitäisi kunakin ajankohtana pystyä ennakoimaan eri toimenpiteistä johtuvia tulevia tuloja. Tämä koskee mm. monia metsätaloudellisia toimenpiteitä. 


\section{LP-menetelmä maatilataloudellisessa suunnittelussa}

Lineaarinen suunnittelu (Linear Programming), jota tässä tutkimuksessa kutsumme LP-menetelmäksi, kuuluu matemaattisiin optimointimenetelmiin, joilla pyritään määrittämään edullisin menettelytapa tietyillä edeltäpäin, asetetuilla edellytyksillä, jotka ovat määrällisesti ilmaistuja. LP-menetelmään kuuluva tekniikka käsittää suhteellisesti yksinkertaista laatua olevien lineaaristen eli suoraviivaisten funktioiden maksimointia tai minimointia, rajoituksin, jotka myös ovat suoraviivaisia. Menetelmässä edellytetään vielä, että relevantit muuttujat eivät voi saada negatiivisia arvoja (DANø, 1957, p. 1, Heady ja Candler 1960, p. 7).

Tässä ei puututa menetelmän matemaattisiin perusteisiin, joita koskevaa kirjallisuutta on runsaasti. Hyvä tiivistetty esitys, jossa käsitellään myös yleisesti sovelletun Simplex-metodin teoriaa sisältyy BECKMANnin saksaksi julkaistuun kirjaseen (1959, p. 101-113). BескмANn mainitsee Нгтснсоск'in (1941), Koopmans'in (1947) ja Dantzigin (1949) perustavaa laatua olevista kirjoituksista, kun taas VARGAn mukaan (ref. ZAPF 1965, p. 12-13) venäläinen KANTOROvich itsenäisesti sovelsi samaa menetelmää, jo v. 1939 ilmestyneessä julkaisussaan. Tyypillisiä ongelmia, joita LP-menetelmällä on pyritty ratkaisemaan on ns. kuljetusongelma (kuljetusten järjestäminen eri pisteiden välillä pienimmin kustannuksin), kokoonpano-ongelma (esim. ihmisen ruokavalion suunnittelu ravintofysiologisten tarpeiden mukaisesti alimmin kustannuksin) sekä tuotantovarojen yhdistelyongelma suurimman mahdollisen voiton tai alhaisimpien yksikkökustannusten saavuttamiseksi tuotannollisessa toiminnassa.

LP-menetelmää sovellettaessa joudutaan tietyt rajoitukset määräämään edeltäpäin joko olemassa olevien tietojen tai harkinnan perusteella. Näillä rajoituksilla on tavallisesti lopputuloksiin ratkaiseva vaikutus. Suunnittelijan henkilökohtaiset käsitykset saattavat näin ollen olla kohtalokkaan määrääviä, etenkin jos rajoitukset asetetaan ahtaiksi. On sanottu: "Sinä voit maksimoida mitä tahdot, kun vain minä saan asettaa rajat». Tässä ilmenee, miten tavoitteen saavuttaminen voi riippua rajoituksista (LINDGREN ja NäsLUND 1968, p. 13).

Yritystaloudellisessa suunnittelussa LP-menetelmä soveltuu parhaiten silloin kun tuotantoprosessit ovat standardoituja ja tuotteiden tuottamiseen käytettävien tuotantovarojen suhde on vallitsevassa tekniikassa yksikäsitteisesti määrätty. SchneIder (1934, p. 3) nimittää välttämättömiä ja kiinteässä suh- 
teessa tuotokseen olevia tuotannontekijöitä rajoittaviksi (limitational) tekijöiksi. Lineaariset funktiot ovat tällaisten tekijäin kohdalla luonnollisia. Monet teollisuudessa esiintyvät kemialliset prosessit; samoinkuin koneiden jatkuvasti samanlaisissa oloissa toistamat mekaaniset toiminnat ovat luonteeltaan tällaisia, ja voidaan helposti soveltaa LP-menetelmällä optimoitaviksi. Edullisimman tuotantosuunnan määrittäminen tämänluontoisia tuotantoprosesseja käsittävissä monituoteyrityksissä onkin nopeasti yleistynyt.

Erityisesti maataloustuotannossa on kuitenkin tavallista toisiaan korvaavien (substitutional) tuotannontekijöiden esiintyminen. Tuotantovarojen suhteen muuttaminen, esim. kohottamalla joidenkin panosta toisiin verrattuna, näiden korvaaminen toisillaan ja eri tuotantoprosessien tuotosten riippuvuus toisistaan monimutkaistaa optimointiongelmia. On jopa sanottu, että on välttämätöntä yksinkertaistaa perusolettamuksia - ja erityisesti luopua rajattoman substituutiomahdollisuuden hypoteesistä - jotta monituoteyritysten suunnittelussa voidaan päästä empiirisesti saavutettaviin tuloksiin (URFF, 1964, p. 149).

Mm. näistä syistä lienee monilla ollut vakavia epäilyjä LP-menetelmän soveltumisesta maatilataloudelliseen suunnitteluun. Mutta äsken mainitut ongelmat kuuluvat kaikkiin muihinkin suunnittelumenetelmiin, joissa optimaalista ratkaisua tavallisesti joudutaan hakemaan hyvin monia mahdollisuuksia kokeilemalla. LP-menetelmän maatilataloudelliset sovellutukset ovat 1950-luvun loppupuolelta lähtien varsin merkittävästi kehittyneet. Tämän tutkimuksen kannalta on eniten vaikutteita saatu URFF'in (1964) ja ZAPFin (1965) tutkimuksista. Menetelmän selkiytymisessä ovat HEADY'n ja CANDLERin esityksen lisäksi RENBorgin (1957), Borganin (1956), Elstrandin (1965) ja HJortshøj-Nielsenin (1964) julkaisut olleet avuksi.

Tässä tutkimuksessa on LP-menetelmää käytetty ensiksikin tutkimusalueen olosuhteihin soveltuvan lypsykarjan ruokintasuunnitelman laatimiseen. ${ }^{1}$ ) Nurmenviljelyn ja maidontuotannon tuotantoprosessit on tämän jälkeen yhdistetty muiden mahdollisten maa- ja metsätaloudellisten tuotantoprosessien kanssa, jälleen LP-menetelmällä, korkeimman mahdollisen katetuoton antavaksi kokonaisuudeksi.

Uudistilalla tapahtuva tuotanto on luonteeltaan muuttuvaa. Se voi tavallisissa oloissa kehittyä edullisimpaan laajuuteensa vasta pitkän ajanjakson kuluessa. Mm. tuottamattomien maiden tuottaviksi saaminen saattaa, etenkin metsätaloudessa, olla jopa monien vuosikymmenien kysymys. Eräs uusi matemaattinen optimointimenetelmä, dynaaminen ohjelmointi (Dynamic Programming) olisi käytettävissä pitkäaikaisen suunnittelutehtävän ratkaisemiseksi (esim. ElsNer, 1964). Menetelmää ovat soveltaneet maa- ja metsätaloudellisiin laskelmiin Ruotsissa MaLmborg (1963) ja LedJE (1963) ja meillä KILKKI ja VÄISÄNEN (1969).

1) Tutkimuksen aikana ei vielä ollut käytettävissä OECD:n julkaisua Cooperative Research on input/output relationships in cow milk production. Paris 1969. 


\section{Käsitteiden määrittelyä}

Sovellettaessa LP-menetelmää maatilataloudelliseen suunnitteluun osoittautuu ensiksikin k a t e t u ot o n käsite tarpeelliseksi ja käyttökelpoiseksi (vrt. URFF 1964, p. 192). Yksityisen tuotannonhaaran tai tuotantoprosessin katetuottoa käytetään kriteerinä pyrittäessä kokonaistuloksen maksimointiin.

$\mathrm{K}$ a t e t u o t t o määritellään erotukseksi suoritteiden arvon eli kokonaistuoton ja muuttuvien kustannusten välillä. M u ut t uvilla kusta n $\mathrm{n} \mathrm{u} \mathrm{ksilla} \mathrm{taas} \mathrm{tarkoitetaan} \mathrm{tuotannon} \mathrm{lisäysten} \mathrm{aikaansaamiseen} \mathrm{tähtää-}$ viä välttämättömiä kustannuksia; tässä mielessä katetuotto on lähellä marginaalituoton vaikeatajuiselta tuntuvaa käsitettä.

Muuttuvat kustannukset on myös määritelty sanomalla, että niihin kuuluvat kaikki muut tuotannosta aiheutuvat kustannukset paitsi niille tuotantovälineille maksettavat korvaukset, jotka ovat käytettävissä kiintein määrin ja joille korvaus syntyy koron luontoisena tulona muuttuvien kustannusten ensin tultua peitetyiksi. Näille tavallisesti useille tuotannonhaaroille yhteisille tuotantovälineille on ominaista, että ne toisinaan voivat muodostaa rajoituksen tuotannon kohottamiselle, toisinaan eivät sitä tee.

Katetuotto on siten tarkoitettu paitsi voitoksi myöskin kiinteiden kustannusten peittämistä varten.

$\mathrm{K}$ i i n t e i h i n k u s t a n n u k i i n ei lueta esim. pelkästään pääomasta aiheutuvia tai yhteiskunnan asettamista velvoitteista johtuvia kustannuksia. Niihin voidaan esim. perheviljelmillä lukea perheen työvoiman ylläpito. Tässä tutkimuksessa on menetelty näin. ${ }^{1}$ )

Kiinteät kustannukset tulevat LP-laskelmaan, sikäli kuin tulevat, rajoitusten muodossa. Siten esimerkiksi yrittäjän käytettävissä oleva maa-ala, useampivuotista sijoittamista varten tarpeellinen rahapääoma, olemassaolevien rakennusten tilavuus sekä perheen työkapasiteetti tulevat kuvaan tässä muodossa.

LP-laskelmassa joudutaan edelleen selvițtämään kunkin tuotannonhaaran tai tuotantoprosessin osalta kunkin rajallisesti käytettävissä olevan tuotannontekijän t a rve. Kysymyksessä on sama asia, josta käytetään nimitystä panos-tuotos-kerroin tai jokapäiväisessä kielenkäytössä usein normiluku.

T u o t a n t o p r os e s silla tarkoitetaan Wittmann'in (ref. URFF 1964, p. 188) mukaan "tuotantotaloudellista perusyksikköä, jolla ilmaistaan tuotantovälineiden määrällisten ja laadullisten panosten ja niillä saatujen tuotosten kiinteä yhteenkytkeminen». ${ }^{2}$ )

Tuotantoprosessin käsitteeseen kuuluu "teknologinen pysyvyys»; sen puitteissa ei tule kysymykseen jonkin tuotantovälineen käytön muuttaminen eikä siis yhden tuotannontekijän korvaaminen toisella.

1) Tutkimuksessamme on edelleen uudisviljelmän maa- ja rakennusomaisuus, samoinkuin hevosen tai traktorin käyttöön kuuluva perusomaisuus, katsottu kiinteitä kustannuksia aiheuttavaksi tuotannontekijäksi. Tutkimuksen tavoitteesta johtuen on esim. uudisraivauskustannus sitävastoin katsottu muuttuvaksi.

2) Tuotantoprosessi on lähellä yleisesti tunnettuja käsitteitä tuotannonhaara tai toiminto, joilla on kuitenkin vähemmän tarkoin määritetty sisältö. 
LP-menetelmässä tulee faktorisubstituution eli tuotannontekijäin toisillaan korvaamisen tilalle tuotantoprosessien korvaaminen toisillaan. Niinpä esim. lannoitteiden käytön lisääminen otetaan huomioon uuden tuotantoprosessin muodossa. Vähenevän tuoton laki tulee näkyviin portaittain muutettavien tuotantoprosessien katetuotoissa.

ZAPF (1965, p. 51-52) korostaa, että selvissä tapauksissa ei laskelmaan ole syytä tuoda monia voimaperäisyysvaihtoehtoja, jos esim. lannoituksen ja väkirehujen käytön lisäykset kohottavat katetuottoja, vaan on syytä ottaa mukaan vain korkeimman katetuoton antava. Hänen mielestään on kuitenkin tällöin edellytettävä, että intensiteetin muutos tuotantoprosessissa ei vaikuta rajoitetussa määrässä esiintyvien tuotannontekijöiden huomioonottoon, riippumatta siitä, onko viimeksimainittujen kapasiteetti talouden ulkoisten vai sen sisäisten tekijäin määräämä. Esim. sikäli kuin väkirehujen käytön lisäys aiheuttaa muutoksia työn määrässä tai perusrehun tarpeessa, tulee jo tarpeelliseksi uuden tuotantoprosessin muodostaminen.

Tuotantoprosessin määritelmä huomioonottaen syntyy tuotantosuunnitelmassa vaikeuksia myöskin tuotannontekijän marginaalituoton suurentuessa esim. tuotannon laajuuden kasvaessa. ZAPF (1965, p. 60-63) on silmälläpitäen esim. sitä työnmenekin suhteellista vähenemistä, joka on havaittavissa karjan koon suurentuessa, kehittänyt menetelmän, jossa tuotantoprosessi määritellään niin, että "säilyttämällä laskumallin lineaarisuus saavutetaan eilineaarinen vaikutus». Menetelmää voitaneen yksinkertaisesti luonnehtia sanomalla, että siinä määritetään ennalta asetetun vaihtelualueen puitteissa ääriarvoja edustavat "osaprosessit», jotka edustavat vaihtelualueen pienintä ja suurinta laajuutta.

Yhdistämällä ne luodaan uusi "keinotekoinen» osaprosessi, jonka marginaalikustannus mainitulla vaihtelualueella on pienempi kuin molempien edellisten. Edullisin tulos löydetään tämän osaprosessin avulla.

Tuotantoprosessit voivat olla suhteellisesti yksinkertaisia, mutta esim. maataloudessa lopullisen tuotteen tuottaminen voi vaatia eriluontoisia tuotantovaiheita ja välituotteiden pitemmälle jalostamista. Tällaisessa tapauksessa tulee esiin kysymys, onko nämä peräkkäisvaiheet jo etukäteen yhdistettävä yhdeksi tuotantoprosessiksi (aggregoitu tuotantoprosessi), vai muodostetaanko niistä eri prosesseja, jotka vasta LP-laskelmassa yhdistetään (disaggregoidut prosessit). Edellinen tapa yksinkertaistaa tietokonekäsittelyä, mutta tekee suunnitelman sidotummaksi kuin jälkimmäinen. ZAPFin (1965, p. 44) mukaan edellinen menettelytapa on käyttökelpoinen vain, jos yhdistettävistä tuotantoprosesseista vain yksi tai korkeintaan kaksi tuotantomenetelmää on mahdollista tai taloudellisesti mielekästä. Jos vaihtoehtoja on enemmän lisääntyy yhdistelmäprosessien luku kohtuuttomasti, eikä tietokonekäsittelyssä enää saavuteta säästöä. Disaggregoitu tekniikka on siten enemmän mahdollisuuksia tarjoava.

Disaggregoidussa tekniikassa välituotteita luovuttavien tuotantoprosessien muuttuvat kustannukset katsotaan negatiivisiksi katetuotoiksi. Esim. rehutuotannon tuloksia voidaan tosin ajatella myytäväksi myöskin markkinoille. Tällöin on muodostettava toinen, markkinoita varten tuottava tuotantoprosessi, jolla on myyntitulojen vuoksi positiivinen katetuotto. Tämä tuotanto- 
prosessi voidaan panna kilpailemaan kotoista jalostustuotantoa palvelevan tuotantoprosessin kanssa.

LP-menetelmän käsitteistöön kuuluu lopuksi o h jel ma (Program). Heady'n ja CANdlerin (1960, p. 16-17) mukaan ohjelma on toimintojen (siis myös tuotantoprosessien) yhdistelmä. Ohjelma on $\mathrm{m}$ a h dolli n e n, jos se on asetettujen rajoitusten puitteissa. Se on siis mikä tahansa yhdistelmä, missä ei käytetä enemmän tuotantovaroja kuin mitä on saatavissa ja missä ei esiinny toimintoja, joissa tuotteita tuotetaan negatiivisia määriä. E d u llis in mahdollin en ohjelma on sellainen, joka voidaan toteuttaa käytettävissä olevien tuotantovarojen puitteissa ja johon ei näissä puitteissa suoritetuilla muutoksilla enää voida saada parannusta. 


\section{Yleisiä tietoja tutkimusalueesta}

Suomussalmen kunnan alasta, joka on 543000 hehtaaria, oli vuoden 1959 maatalouslaskennan mukaan 364205 ha kasvullista ja huonokasvuista metsämaata, josta n. 2/3 kuuluu valtiolle ja erilaisille yhtiöille ja vain 104675 ha yksityisille henkilöille. Maatalouslaskennan piiriin kuuluvilla maatalousviljelmillä, joilla edellytettiin olevan joko vähintään 0.25 ha peltoa tai 0.50 ha yhteensä maatalousmaata, oli kunnassa peltoa 6726 ha, luonnonniittyä 297 ha, raivattua laidunta 267 ha, metsää 110553 ha, josta huonokasvuista 27456 ha, sekä joutomaata 52642 ha. Kun viljelmiä oli kaikkiaan 1901, viljelmän keskimääräinen ala oli 3.53 ha peltoa tai 3.83 ha yhteensä maatalousmaata, 43.71 ha kasvullista ja 14.44 ha huonokasvuista metsämaata sekä 27.64 ha joutomaata eli kaikkiaan 89.62 ha maata. Suomussalmella oli v. 1959 vain 2 maatalousviljelmää, joilla oli yli 15 ha peltoa, kun taas peltoalaltaan alle 2 ha:n viljelmiä oli 436 , niillä keskimäärin 0.84 ha maatalousmaata ja 30.82 ha metsämaata (SVT III: 54).

Alueen metsävaltaisuus kuvastuu selvästi näistä luvuista, samoinkuin maatalousviljelmien viljeltyjen alojen yleinen pienuus. Alueen väestötiheys on myös hyvin vähäinen, 2.9 asukasta $\mathrm{km}^{2}$ :llä. Ammatissa toimivan maatalous- ja metsätalousväestön luku on vuoden 1960 väestölaskennan mukaan 4318, josta 1740 avustavaa perheenjäsentä, yleensä perheenemäntiä, jotka huolehtivat karjasta. Maan tarjoamien tuotantovarojen määrä on kunnan alueella yhtä täysi-ikäistä ammatissa toimivaa miestä kohden n. 2.6 ha jo viljelyksessä olevaa maata, n. 140 ha metsää, josta n. 30 ha heikkotuottoista korpea tai rämettä sekä ehkä saman verran aukeata, tähän mennessä täysin tuottamatonta suomaata.

Suomussalmen kunnan alueelta ei ole edellä esitettyä tarkempia tietoja maan ja metsien laadusta. Verraten yksityiskohtaisia tietoja on sitävastoin Kainuun metsänhoitolautakunnan alueesta, josta Suomussalmen pinta-ala on $23.2 \%$ ja jonka luonto tuskin missään huomattavasti poikkeaa tämän osan yleistyypistä. Niinpä valtakunnan metsien linja-arvioinnin tuloksiin sisältyy mm. tietoja metsien jakaantumisesta metsätyyppeihin, metsän jako kasvulliseen ja huonokasvuiseen sekä huonokasvuisen metsän ja joutomaan tarkempi jaoittelu (Ilvessalo 1957, p. 16). Edelleen esitetään kasvun jakaantuminen eri läpimittaryhmiin, kasvu ikäluokittain, keskikuutio metsätyypeittäin, kuitenkin niin, että eräitä tyyppejä on yhdistetty, sekä pääpuulajien kuutiomäärät eräissä tyyppiryhmissä ikäluokittain eriteltynä (p. 46, 48, 
78). Tutkimuksemme kannalta tärkeimmät tiedot esitetään alempana rinnan tutkimustiloja koskevien tietojen kanssa.

Suomussalmen valtionmetsistä, joiden ala on yhteensä 136100 ha eli n. $25 \%$ kunnan kokonaisalasta, on valtakunnan metsien inventoinnissa 1951 53 ja metsähallituksen siihen liittyvässä valtion metsiin kohdistamassa täydennystutkimuksessa saatu varsin monipuolisia tietoja (Linnamies 1959). Lisäksi on Metsähallituksen tilastossa jatkuvia vuosittaisia tietoja Suomussalmen hoitoalueesta. Näitä lukuja on vertailuja silmälläpitäen niinikään otettu tutkimustilojen metsätaloutta kuvaaviin taulukoihin.

Metsän tuottoarvioiden kannalta ovat erittäin mielenkiintoisia ILvEssALon (1967) vasta äskettäin julkaisemat tiedot luonnonnormaalien metsälöiden kehityksestä Kainuussa ja sen lähiympäristössä. Lähinnä niiden pohjalle on rakennettu tämän tutkimuksen kivennäismaiden metsiä koskevat arviolaskelmat.

Tutkimuksemme kannalta ovat mielenkiintoisia myös HeIKuraIsen (1959, p. 86-95) maan eri osissa olevilla koealoilla suoritettuihin havaintoihin perustuvat arviot ojitetuilla soilla saavutettavasta kuutiokasvusta, kuutiomäärän funktioina esitettyinä. Tutkimusaluettamme vastaavalta leveysasteelta on tosin vain aniharvoja havaintoja (lähinnä ns. huonommalta sararämeeltä), mutta Heikurainen (p. 97-100) on ilmeisesti melkoisella todennäköisyydellä voinut arvioida samanlaisten suotyyppien suhteellisten tuottojen muutokset etelästä pohjoiseen ja lännestä itään siirryttäessä. Niiden nojalla on mahdollista tehdä arvioita myös tutkimusalueella ojitettavien, erilaista puustoa käsittävien soiden kuutiokasvusta. Mainittakoon, että kuutiokasvun suhdeluku Suomussalmen seuduilla on n. 70, kun Tampereen-Savonlinnan korkeudella esiintyvää suhteellista kasvua merkitään 100:1la.

Niin metsätalouden kuin peltoviljelyksenkin edellytyksiin on alueen ilmastollisilla suhteilla huomattava merkitys. KORHOSEN (1958 b, p. 344-348) esittämien kartakkeiden mukaan Suomussalmi kuuluu vyöhykkeisiin, joissa vuoden keskilämpötila on $n .+1^{\circ}$, heinäkuun keskilämpötila $n .+15^{\circ}$ ja helmikuun keskilämpötila n. $-12^{\circ}$. Vuotuinen sademäärä on n. $600 \mathrm{~mm}$ ja haihtuminen $200-250 \mathrm{~mm}$. CAJANDERin $(1927$, p. 130, 147, 152) mukaan alkaa maataloudellinen muokkauskausi alueella keskimäärin 17.5. ja päättyy 25. 10., laidunkausi vastaavasti 1.6. ja 25.9. ja todellinen laiduntamisaika 12.6. ja 17.9. Kasvukauden tehoisa lämpösumma on KERÄsEN (1942) mukaan $700^{\circ}-800^{\circ}$.

Maa- ja metsätaloudessa suoritettavien töiden kannalta on merkitystä myöskin pysyvän lumipeitteen tulo- ja lähtöajalla sekä sadepäivien luvulla kasvukauden eri kuukausina. Simojoen (ref. Korhonen 1958 a, p. 135-142) mukaan syntyi pysyvä lumipeite alueelle 1892-1941 keskim. 5. 11.-10. 11 . välillä ja hävisi aukeilla 15.5. vaiheilla, metsissä 25.5. Lumipeitteen paksuudesta kertovat tilastot talvikausilta, ilmoittaen päivien luvun, joina lunta on ollut sopivasti, liiaksi tai liian vähän.

\begin{tabular}{|c|c|c|c|c|}
\hline Lumipeitteen esiintyminen - Snow cover & XII & I & II & III \\
\hline Lunta sopivasti $(11-50 \mathrm{~cm})$. & 24.8 & 14.9 & 4.5 & 1.2 \\
\hline Lunta liiaksi (yli $51 \mathrm{~cm}$ ) ............. & 4.3 & 16.1 & 23.5 & 29.8 \\
\hline 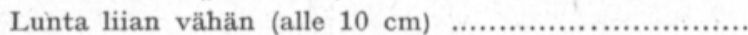 & 1.9 & 0.0 & 0.0 & 0.0 \\
\hline
\end{tabular}


Kesäpuoliskolla on päiviä, joina sademäärä on ollut yli $1 \mathrm{~mm}$ tai yli 0.1 mm ollut eri kuukausina keskimäärin seuraavasti.

\begin{tabular}{|c|c|c|c|c|c|}
\hline Sademäärä - Rainfall & $\mathrm{v}$ & VI & VII & VIII & IX \\
\hline \multicolumn{6}{|l|}{ Suomussalmen kirkonkylä } \\
\hline yli $1 \mathrm{~mm}$ & 7.4 & 10.4 & 11.1 & 10.6 & 11.2 \\
\hline yli $0.1 \mathrm{~mm}$ & 11.3 & 14.7 & 14.1 & 15.2 & 17.6 \\
\hline \multicolumn{6}{|l|}{ Ylivuokki } \\
\hline yli $0.1 \mathrm{~mm}$ & 9.8 & 12.5 & 12.5 & 12.7 & 13.2 \\
\hline
\end{tabular}

\section{Eri viljelykasvien viljely}

Maatalouslaskentojen perusteella voidaan selvittää $\mathrm{mm}$. eri viljelykasvien alat sekä v. 1959 myös niiden viljelyn yleisyys kunnan alueella. Seuraava asetelma antaa tästä yleiskuvan (vuoden 1950 luvut eivät tosin ole aivan tarkkoja viljojen osalta). Mukaan on otettu myös painatusvaiheessa tiedossa olevat vuoden 1969 laskennasta saadut luvut.

\begin{tabular}{|c|c|c|c|c|c|}
\hline & \multicolumn{3}{|c|}{$\begin{array}{l}\text { Koko viljelyala, ha } \\
\text { Area under cultivation }\end{array}$} & \multicolumn{2}{|c|}{$\begin{array}{c}\text { Keskim. ala tiloilla, } \\
\text { joilla viljelty } \\
\text { Average on farms } \\
\text { cultivating, ha }\end{array}$} \\
\hline & 1950 & 1959 & 1969 & 1959 & 1969 \\
\hline Kevätvehnä - Spring wheat ................. & 6 & 1 & - & 0.25 & - \\
\hline 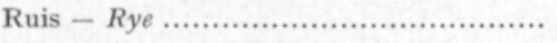 & 60 & 12 & 55 & 0.18 & 0.24 \\
\hline Ohra - Barley ................................. & 430 & 516 & 656 & 0.52 & 0.85 \\
\hline Kaura - Oats ................................. & 378 & 148 & 74 & 0.32 & 0.36 \\
\hline Peruna - Potato ................................ & 189 & 198 & 198 & 0.15 & 0.13 \\
\hline Juurikasvit - Roots .......................... & 15 & 16 & 48 & 0.14 & 0.09 \\
\hline Peltoheinä, kuiv. - Grassland for hay ..... & 2293 & 4972 & 5356 & 2.73 & 3.44 \\
\hline Peltoheinä, AIV - Grassl. for silage ......... & 40 & 84 & 119 & 1.68 & 1.09 \\
\hline Heinänsiemen - Grassl. for seed ............. & 16 & 16 & 3 & 0.41 & 0.38 \\
\hline Peltolaidun - Pasture ........................ & 3 & 631 & 1551 & 1.05 & 1.34 \\
\hline Muut kasvit - Other crops .................. & 252 & 88 & 522 & 0.37 & 1.17 \\
\hline Kesanto - Fallow .............................. & 46 & 31 & 43 & 0.65 & 0.98 \\
\hline
\end{tabular}

Peltoalasta on valtaosa, v. $195985 \%$, ollut heinänurmilla. Yhä laajenevaa osaa niistä on käytetty laiduntamiseen. Vain $10 \%$ peltoalasta on ollut viljalla, josta $3 / 4$ ohralla. Kauraa on viljelty n. $1 / 5$ vilja-alasta. Sen samoin kuin rukiin viljely on vuoden 1950 jälkeen huomattavasti supistunut. Kevätvehnää on viljelty vain muutamalla tilalla.

\section{Kotieläinkanta}

Kunnan kotieläinkanta vv. 1950, 1959 ja 1969 selviää seuraavasta asetelmasta. 


\begin{tabular}{|c|c|c|c|c|c|}
\hline & \multicolumn{3}{|c|}{ Lukumäärä - Number } & \multicolumn{2}{|c|}{$\begin{array}{l}\text { Tila a kohden } \\
\text { Per farm }\end{array}$} \\
\hline & 1950 & 1959 & 1969 & 1959 & 1969 \\
\hline Täysikasv. hevosia - Adult horses ........................ & 1059 & 991 & 420 & 0.52 & 0.29 \\
\hline Nuoria hev. ja varsoja - Young horses and foals .... & 44 & 13 & 7 & 0.01 & 0.00 \\
\hline 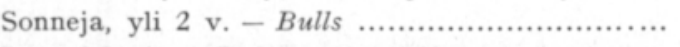 & 62 & 34 & 6 & 0.02 & 0.00 \\
\hline Lypsylehmiä - Dairy cows ............................... & 4203 & 5393 & 5350 & 2.84 & 3.69 \\
\hline Hiehoja ja nuoria sonneja - Heifers and young bulls & 838 & 929 & 940 & 0.49 & 0.65 \\
\hline Vasikoita, alle 1 v. - Calves …........................... & 1269 & 2727 & 3548 & 1.43 & 2.45 \\
\hline 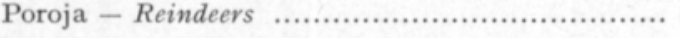 & 235 & 546 & . & 0.29 & . \\
\hline 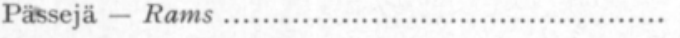 & 389 & 206 & $\left.395^{1}\right)$ & 0.11 & $\left.0.27^{1}\right)$ \\
\hline 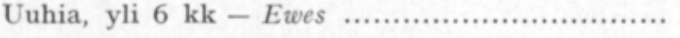 & 3626 & 1365 & & 0.72 & \\
\hline 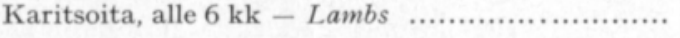 & 3893 & 1748 & 512 & 0.92 & 0.35 \\
\hline 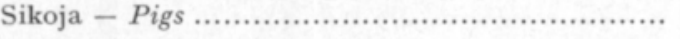 & 279 & 464 & 353 & 0.24 & 0.24 \\
\hline 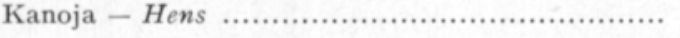 & 1378 & 1770 & 2133 & 0.93 & 1.47 \\
\hline
\end{tabular}

1) Pässejä ja uuhia yhteensä.

\section{Tutkimustilojen valinta}

Tutkimustilat piti tutkimusohjelman mukaan valita niistä asutustiloista, jotka vuoden 1945 maanhankintalain mukaan oli muodostettu uudistilan perustamispalkkioihin oikeutettuina ns. kylminä tiloina. Näille tiloille oli, kuten tunnettua, käytännöllisesti katsoen kaikki tarvittava viljelysmaa hankittava raivaamalla, samalla kun myös rakentaminen oli aloitettava aivan alusta. Suomussalmen tutkimustilat valittiin Jumaliskylän ja Tenhusensuon ryhmäasutuksista (n. 20 km Suomussalmen kirkolta etelään, Kerälän ja Moisiovaaran välillä olevien asutusteiden varsilla). Alueen leveysaste on $64^{\circ} 45$,' pituusaste n. $29^{\circ} 10^{\prime}$ ja korkeus merenpinnasta n. 200 m. Asutustilat luovutettiin asukkaiden hallintaan yleensä 1950-luvun alussa. Tilat valittiin arpomalla siten, että $\mathbf{5 0 \%}$ asutusalueiden tiloista tuli otokseen. Oheinen kartta antaa kuvan tilojen asemasta sekä niiden viljelysten sijainnista ja laajuudesta vuoden 1963 lopulla (kuva 1). Kuvista $2 \mathrm{~A}-\mathrm{D}$ voi nähdä $\mathrm{mm}$; minkä luontoista viljelty ja viljelykelpoinen maa on tutkimusalueella.

Otokseen sisältyville asutustiloille oli annettu niitä muodostettaessa yhteensä 2944 ha maata, eli keskim. 142 ha tilaa kohden. Tämän alan jakaantuminen kasvulliseen ja huonokasvuiseen metsämaahan sekä joutomaahan näkyy taulukosta 1 , johon vertailun vuoksi on otettu vastaavat prosenttiluvut Kainuun metsänhoitolautakunnan koko alueesta sekä Suomussalmen valtion metsistä.

Suomussalmen asutustilojen metsistä on Kainuun metsänhoitolautakunnan arkistoista voitu saada verraten tarkkoja tietoja. Metsätaloussuunnitelmia oli v. 196516 tilalla. Peltomaita koskevia viljavuuskarttoja oli laadittu 5 tilalle. Kun Suomussalmen tutkimustilat lisäksi muodostavat ryhmän, jossa luonnonsuhteet ovat yhdenmukaisia, niiden käsitteleminen omana ryhmänään tuntuu oikeutetulta siitäkin huolimatta, että niiden luku on vain 20 .

Tässä tutkimuksessa tutkimustiloja käsitellään kahtena ryhmänä pelloilta hehtaaria kohden saadun rehuyksikkösadon perusteella. Tutkimustilojen keski- 
arvoa korkeampia satotuloksia saaneet on luokiteltu ryhmään $\mathrm{A}$, sitä alempia saaneet ryhmään B. Tällä luokittelulla ei ole osoittautunut olevan kovin suurta merkitystä, koska satotulosten riippuvuutta mitattavista tekijöistä on ollut vaikea todeta.

Taulukko 1. Tutkimustilojen kokonaispinta-alan jakaantuminen prosentteina kasvulliseen ja huonokasvuiseen metsämaahan sekä joutomaahan tilojen perustamisajankohtana.

Table 1. Repartition of the total area of the study farms into productive and unproductive forest land and waste land when establishing the farms.

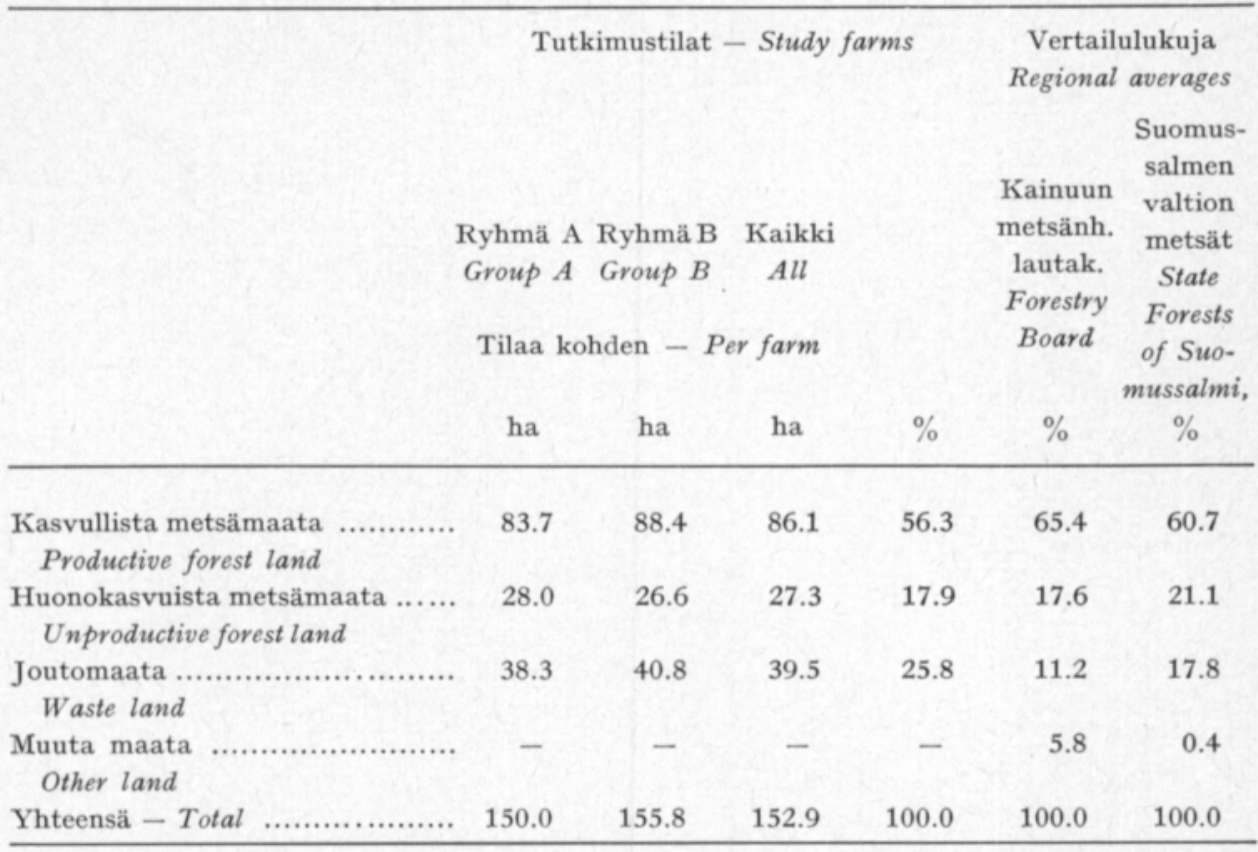

Taulukosta 1 selviää, että tutkimustiloilla on perustettaessa ollut runsaasti puolet (n. $56 \%$ ) alasta kasvullista, vajaa viidennes (n. $18 \%$ ) huonokasvuista metsämaata ja vähän yli neljäsosa (n. $26 \%$ ) joutomaata. Huonokasvuiset metsät ovat lähinnä korpia ja rämeitä (edellisiä oli Kainuun metsänhoitolautakunnan alueella $8.7 \%$ ja jälkimmäisiä $86.9 \%$ tästä ryhmästä). Myös joutomaat, joita tutkimustiloilla on ollut suhteellisesti enemmän kuin alueen valtion metsissä, ovat näillä alueilla miltei yksinomaan soita (metsänhoitolautakunnan alueella oli niissä korpia $0.7 \%$, rämeitä $5.4 \%$, nevoja $86.6 \%$ ja lettoja $5.6 \%$, lopun alan ollessa lähinnä ojitettuja soita). Avosoita olisi tämän mukaan $23 \%$ koko maa-alasta ja enemmän tai vähemmän kitukasvuista metsää kasvavaa suota n. $17 \%$ koko maa-alasta.

Tutkimustilojen maaperäsuhteista oli perustamisvaiheessa merkitty tiluskarttoihin tietoja, joiden pohjalla on mahdollisuus luokitella tutkimusajankohtaan mennessä raivatut pellot sekä viljelykelpoiseksi ilmoitettu maa verraten yksityiskohtaisesti maalajin mukaisiin luokkiin. Taulukossa 2 on tällainen luokittelu suoritettu maaperän mukaan, kun taas taulukossa 3 on esitetty luokittelu metsä- ja suotyypeittäin tutkimusajankohtana jäljellä olevan 


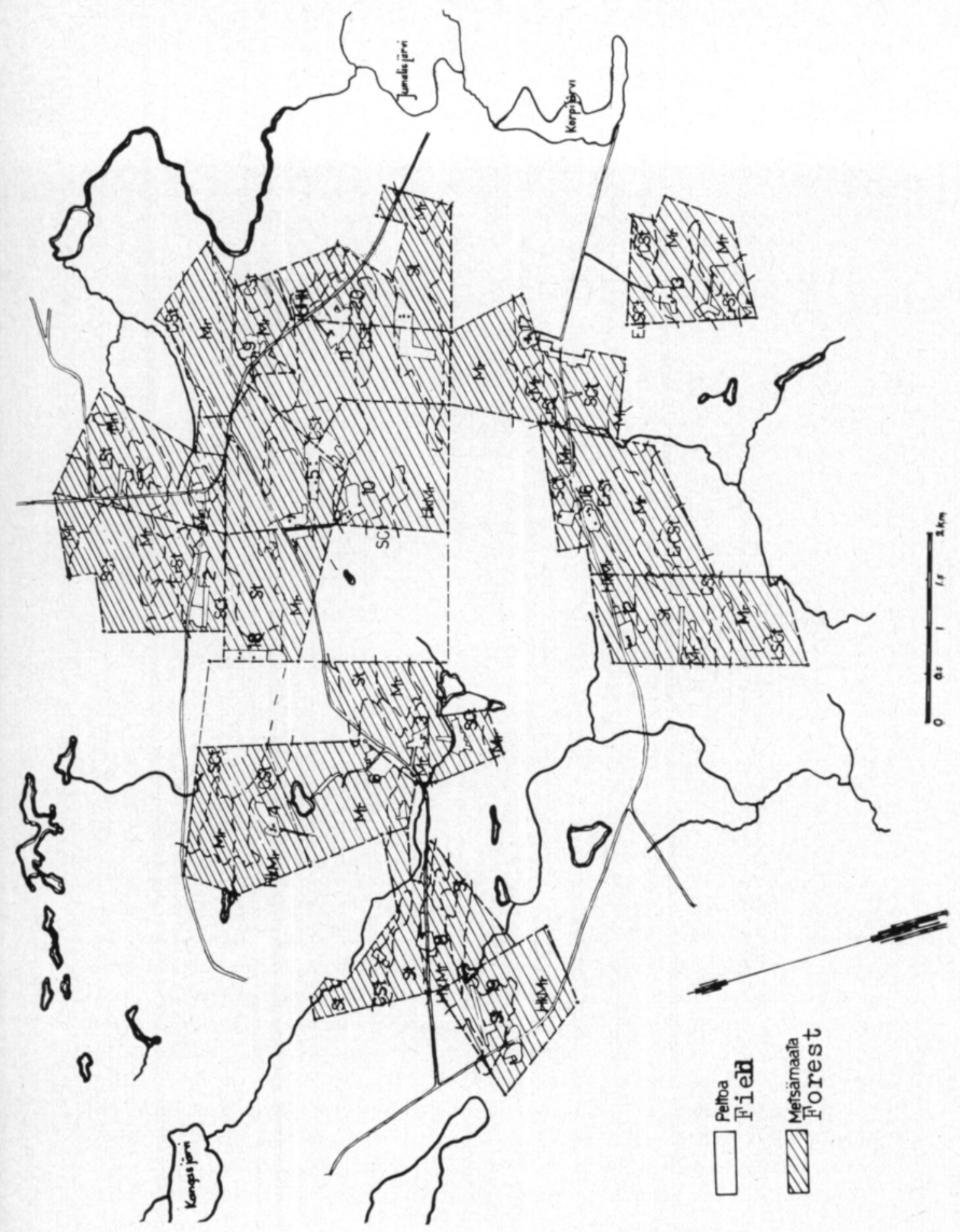

Kuva 1. Suomussalmen tutkimustilat. (Maalajit, ks. p. 350-351).

Figure 1. Study farms of Suomussalmi. (For soil types, see Appendix 3). 


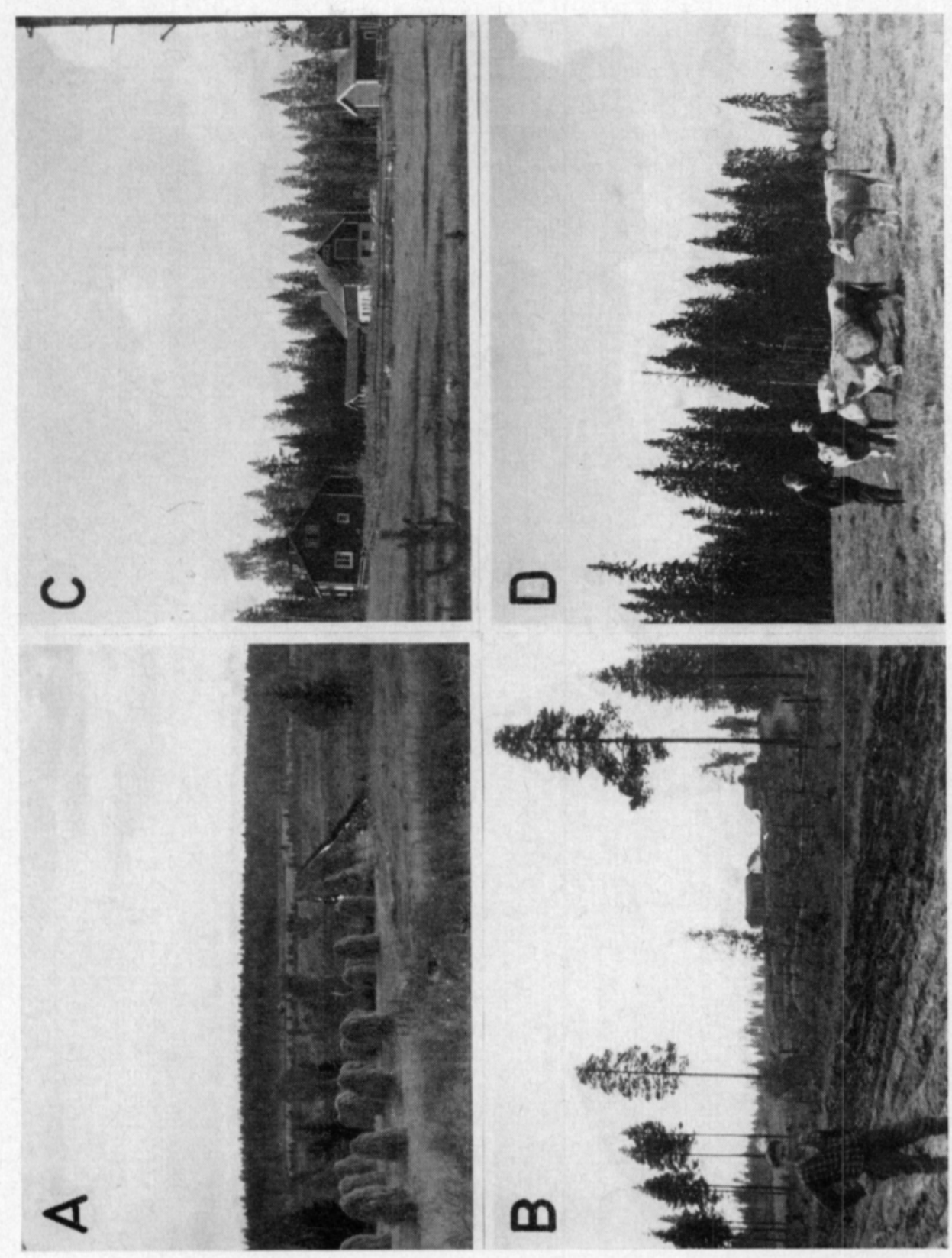

हิ ฮึ ฐ

त)

क ल

ㅎํำ

\%

ษิ

ํํㄹ $>$

놇 녕 땡

욜

1 르

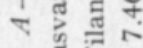

$\checkmark$ च

ڤำ 홀

记焉

कू

| है 일 >

ذِ

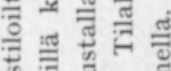

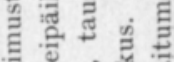

है

E

뜰 을 흘

纯

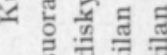

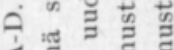

<药

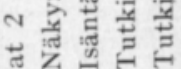

ப் $\dot{1} \dot{0}$ 
viljelykelpoisen maan osalta. Viimeksi mainittu luokittelu on tarkoitettu valaisemaan erityisesti turvemaiden maa- ja metsätaloudellisia tuotantomahdollisuuksia, käytettäessä hyväksi aikaisempia tutkimustuloksia tästä osasta maata.

Taulukosta 2 selviää, että alueen kivennäismaat ovat pääasiassa erilaisia moreenimaita. Tämä on sopusoinnussa myös kunnassa suoritettujen viljavuustutkimusten jakautuman kanssa (KURKI 1963, p. 75). Viimeksimainituissa esiintyy tosin pienehkö määrä $(5 \%)$ multamaita ja myös n. $9 \%$ liejumaita, jotka ilmeisesti on tavattu jo vanhastaan viljellyiltä alueilta. Viljavuustutkimuksen mukaan on $25.6 \%$ viljelykelpoisesta maasta ollut hietamoreenia (HtMr). On mahdollista, että moreeni-nimitys on tutkimusalueiden luokittelussa vastannut lähinnä tätä käsitettä.

Taulukko 2. Pellon ja viljelykelpoisen maan luokittelu maalajin perusteella.

Table 2. Classification of the present arable land and cultivable land according to the soil type.

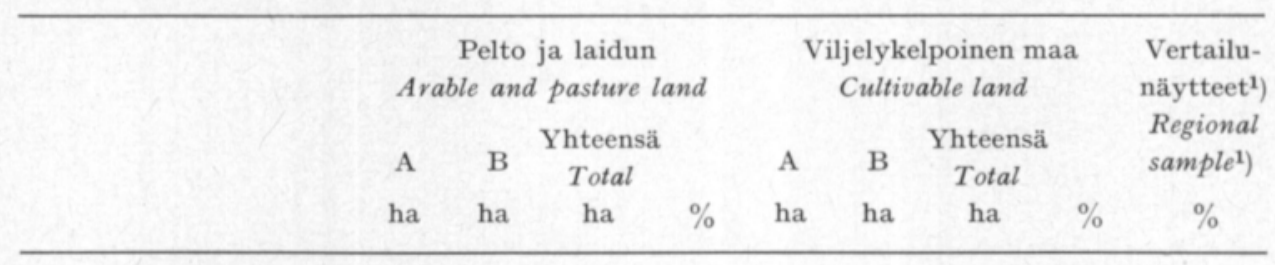

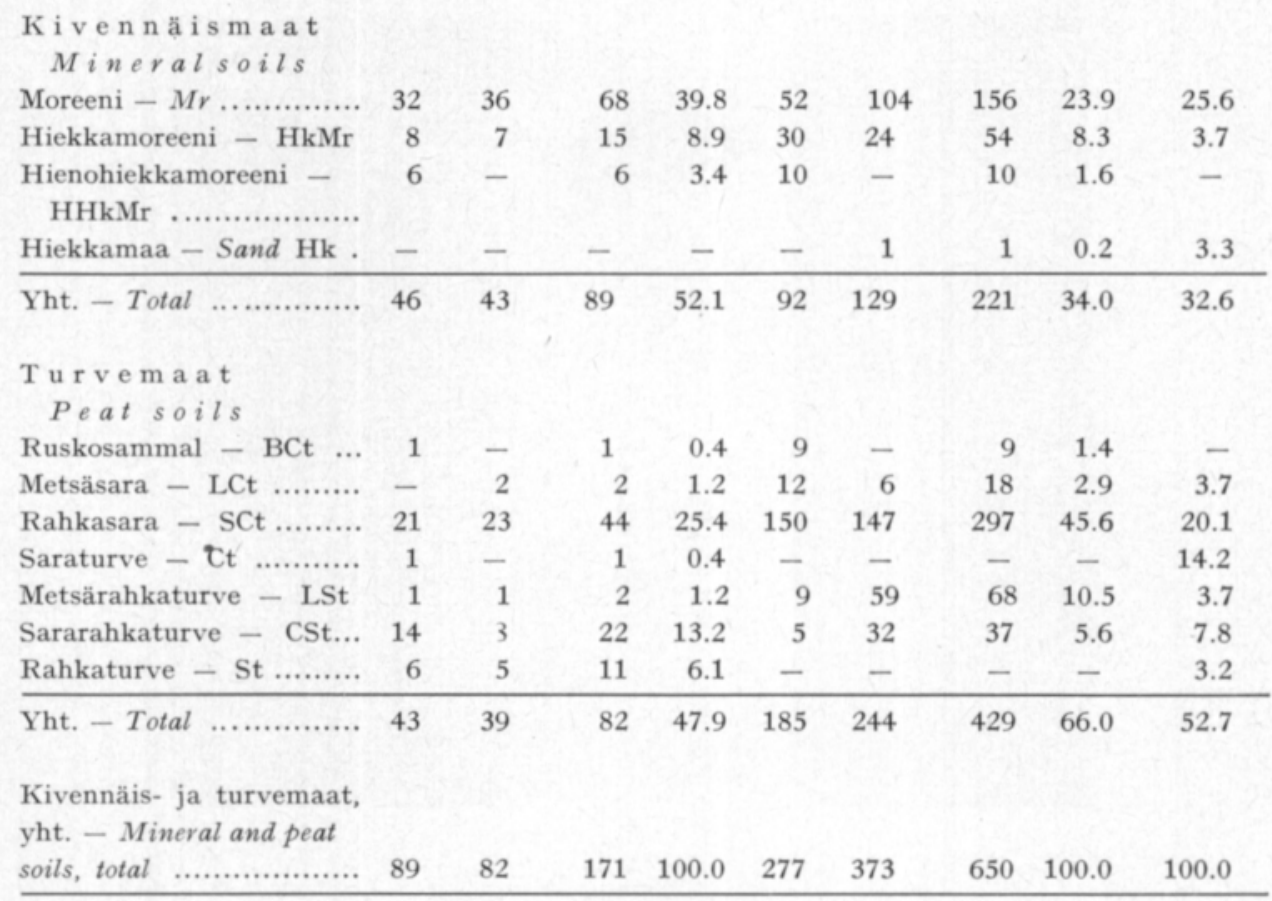

1) Keskimäärät Viljavuuspalvelu Oy:n 218 maanäytteestä kunnan alueella vertailun vuoksi.

1) Averages of 218 soil samples from Suomussalmi commune analyzed by Soil Fertility Service Soil types: see Appendix 3. 
Taulukkoon 3 on suotyyppien kohdalla merkitty niiden koko aluetta vastaava metsäojitusboniteetti Herkuraisen (1961 ja 1964) tutkimusten ja hänen käyttämänsä asteikon mukaan. Myöskin on esitetty hänen puuston volyymiä ja vuotuista kasvua $\left(\mathrm{k}-\mathrm{m}^{3}\right)$ koskevat arviolukunsa. Kivennäismaiden kohdalta esitetään maalajinimitysten ohella niitä vastaavat metsätyypit ja ne keskimääräiset puustovolyymit ja kasvukuutiot, jotka Kainuun metsänhoitolautakunnan alueella on todettu vuosien 1951-53 linja-arvioinnissa.

Viljelykelpoiset moreenimaat kuuluvat yleensä kasvullisiin metsämaihin, kun taas turvemaat ovat suurimmalta osalta huonokasvuisiin metsämaihin tai joutomaihin kuuluvia. Noin $13 \%$ turvemaista on täysin aukeita soita

Taulukko 3. Jäljellä olevien viljelykelpoisten maiden jakaantuminen metsä- ja suotyyppeihinvastaavanlaisten metsämaiden keskimääräinen kuutiomäärä ja kasvu seka suomaiden metsä, ojitusboniteetti ${ }^{\mathbf{1}}$.

Table 3. Classification of still existing cultivable land into the forest and peat site quality types, the timber stand and growth, and average site quality in case of forest drainage ${ }^{1}$ )

\begin{tabular}{|c|c|c|c|c|c|c|}
\hline $\begin{array}{l}\text { Maaperä-, metsä- ja suotyyppi } \\
\text { Soil-, forest- or peat site quality type }\end{array}$ & A & B & $\begin{array}{l}\text { Yht. } \\
\text { Total } \\
\text { ha }\end{array}$ & $\begin{array}{c}\text { Metsäoj. } \\
\text { boniteetti } \\
\text { Site } \\
\text { quality }\end{array}$ & $\begin{array}{l}\text { Kuutio- } \\
\text { määrä } \\
\text { k-m³/ha } \\
\text { Volume }\end{array}$ & $\begin{array}{l}\text { Kuutio- } \\
\text { kasvu } \\
\text { k-m } \mathrm{m}^{3} / \mathrm{ha} \\
\text { Growth }\end{array}$ \\
\hline Moreeni, Mr ....................... MT & 41 & 60 & 101 & & & \\
\hline Hiekkamoreeni $\mathrm{HkMr} . . . . . \ldots \ldots \ldots . . .$. MT & 30 & 18 & 48 & & & \\
\hline Moreeni, Mr ........................ VMT & - & 31 & 31 & & & 2.3 \\
\hline Hiekkamoreeni, HkMr .............. VMT & - & 4 & 4 & & & 2.3 \\
\hline Hienohiekkamoreeni, HHkMr $\ldots$ VMT & 10 & - & 10 & & & 2.3 \\
\hline 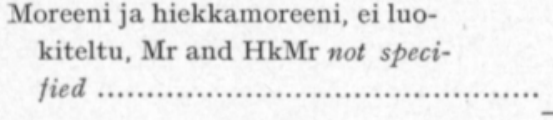 & 11 & 10 & 21 & & & \\
\hline $\begin{array}{l}\text { Yhteensä kivennäismaita } \ldots . . . \ldots \ldots \ldots \ldots . . . . . . \\
\text { Mineral soils, Total }\end{array}$ & 92 & 123 & 215 & & & \\
\hline Kangaskorpi, KgK . ........................... & - & 37 & 37 & $5-4$ & 65 & 1.4 \\
\hline 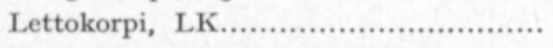 & 5 & 1 & 6 & $6-5$ & & \\
\hline Ruohoinen nevakorpi, RhNK .............. & - & 2 & 2 & $6-5$ & & \\
\hline Ruohoinen sararäme, RhSR ................ & 7 & 46 & 53 & 5 & 15 & 0.5 \\
\hline Varsin. sararäme, VSR ...................... & 30 & 50 & 80 & 4 & 15 & 0.5 \\
\hline Varsin. lettoräme, VLR....................... & 44 & 42 & 86 & $6-5$ & 15 & 0.5 \\
\hline Rämeletto, RL .............................. & 46 & 31 & 77 & 2 & 15 & 0.5 \\
\hline Ruoh. saraneva, RhSN........................ & 17 & 0 & 17 & $6-5$ & 0 & 0 \\
\hline Kalvakkaneva, KN ........................... & - & 3 & 3 & 1 & 0 & 0 \\
\hline Vars. rimpineva, VRiN...................... & 2 & 9 & 11 & 1 & 0 & 0 \\
\hline Subsecundum rimpineva, SubRiN .......... & 9 & - & 9 & 1 & 0 & 0 \\
\hline Turvemaita - Peat soils & 160 & 221 & 381 & & & \\
\hline
\end{tabular}

1) Turvemaiden metsäojitusboniteetti ja eri suotyyppien keskikuutiomäärä ja kasvu hehtaaria kohden Kainuun olosuhteissa (vrt. HeIKURAINen 1961, p. 10-11; ibid. 1964, p. 30-31) esitetty ohella.

1) Average site quality in case of forest drainage, as well as the average volume and growth of timber stand of undrained peats of the region (Comp. HeIKURAINEN 1961, p. 10-11; ibid. 1564, p. 30-31). 
ja n. $80 \%$ on sellaisia, joilla Kainuussa vallitsevissa olosuhteissa puuston kuutiomäärä on vain $15 \mathrm{k}-\mathrm{m}^{3} / \mathrm{ha}$ ja vuotuinen kasvu $0.5 \mathrm{k}-\mathrm{m}^{3} / \mathrm{ha}$. Noin $3 / 4$ turvemaista kuuluu suotyyppeihin, joiden metsäojitusboniteetti on yli 3 ja joiden ojittaminen metsänkasvatusta varten saattaisi alueen ilmastollisissa oloissa Heikuraisen (1964, p. 29) mukaan olla suositeltavaa.

Kasvullisen metsän jakaantumisesta metsätyyppeihin antaa kuvan taulukko 4, jossa on myös vastaavat jakautumat Kainuun metsänhoitolautakunnan alueesta sekä Suomussalmen valtion metsistä. Kuitenkin on huomattava, että tutkimustilojen metsätyypit on esitetty vanhan luokituksen mukaan, kun taas vertailuluvut on laskettu uuden luokituksen mukaisista metsätyypeistä.

Taulukosta selviää, että mustikkatyypin ryhmä on pinta-alan suhteen tutkimustiloilla heikommin edustettu kuin Suomussalmen valtion metsissä ja Kainuun metsänhoitolautakunnan koko alueella keskimäärin. Noin puolet kasvullisesta metsäalasta kuuluu tutkimustiloilla puolukkatyypin ryhmään, joka on runsaammin edustettuna kuin vertailualueilla. Suoperäiset tyypit käsittävät n. kolmanneksen kasvullisesta metsäalasta ja kasvullinen räme yksin neljänneksen.

Taulukko 4. Kasvullisen metsämaan jakautuminen metsätyyppeihin prosentteina.

Table 4. Distribution of productive forest land into site quality types, per cent ${ }^{1}$ )

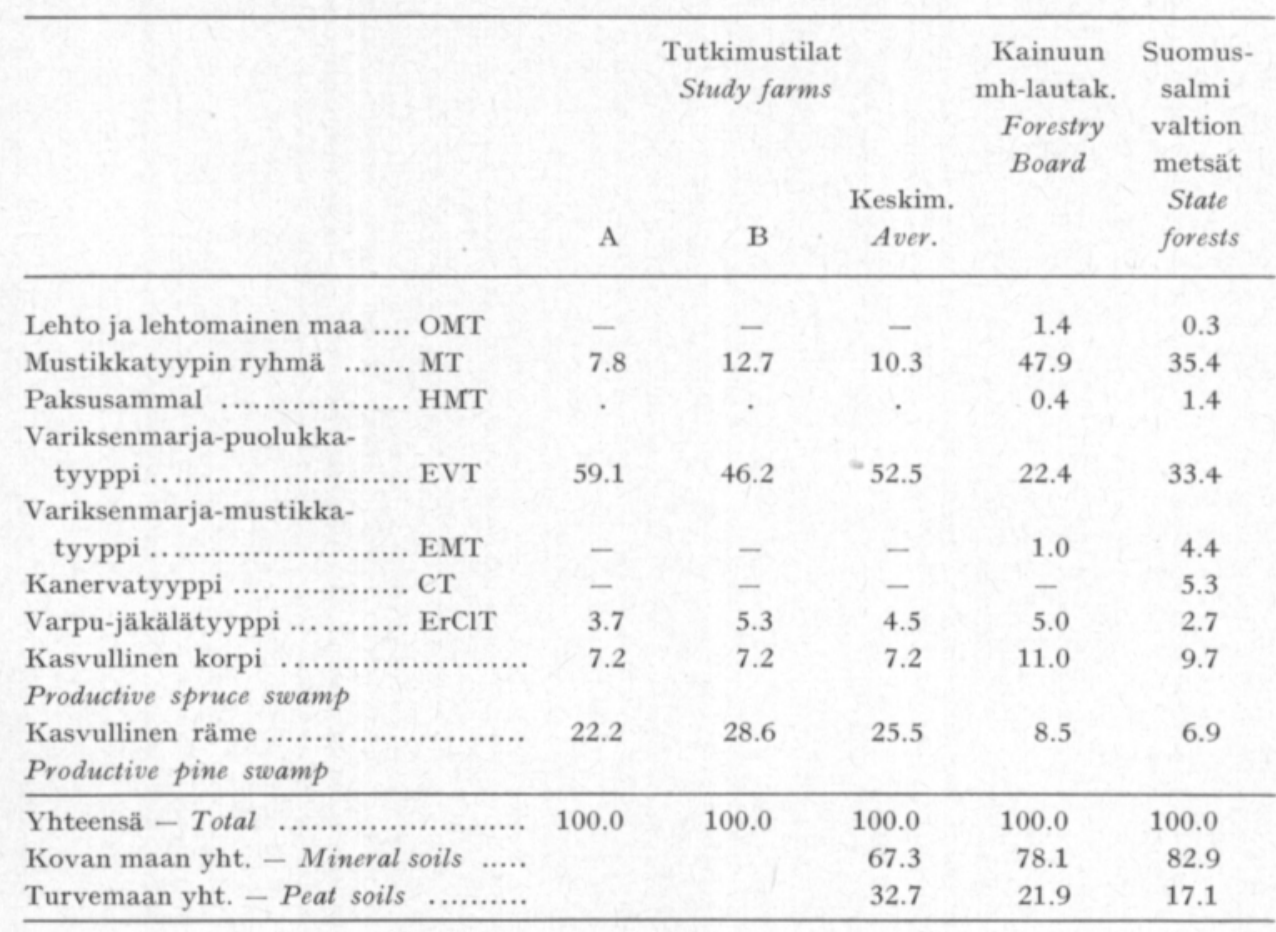

1) Forest site quality types: OMT

MT

HMT

EVT

EMT

CT

ErClT
Oxalis-Myrtillus

Myrtillus

Hylocomium-Myrtillus

Empetrum-Vaccinium

Empetrum-Myrtillus

Calluna

Ericaceae-Cladina type

,

,

,

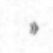

,


Taulukosta 5 nähdään tutkimustilojen kasvullisen metsän jakaantuminen veroluokkiin. Veroluokat muodostetaan metsäverotuksessa, kuten tunnettua, metsätyyppijakautuman mukaan. Vertailu valtion hoitoalueen jakautumaan osoittaa, että ensimmäisen veroluokan maata on tutkimustiloilla suhteellisesti vähemmän kuin valtion metsässä. Verokuutio on tutkimustiloilla keskimäärin 1.83, valtionmetsässä 1.87. - Verokuutiometrin hinta oli 3. vyöhykkeessä, joka vastannee tutkimustilojen olosuhteita, v. 1961 1: 60 (2. vyöhykkeessä se oli 2: 40 ja 3 . vyöhykkeessä 3:40). - Alueella ei huonokasvuiselle metsälle aseteta verolukuja.

Taulukko 5. Kasvullisen metsämaan jakaantuminen eri veroluokkiin ja verokuutioluku $\mathrm{k}$ - $\mathrm{m}^{\mathbf{3}} / \mathrm{ha}$ Table 5. Distribution of productive forest land into taxation classes and taxed volume increment.

\begin{tabular}{|c|c|c|c|c|c|}
\hline $\begin{array}{l}\text { Veroluokat } \\
\text { Tax classification }\end{array}$ & $\begin{array}{l}\text { Metsätyyppi } \\
\text { Site quality }\end{array}$ & Tutkimustilat & $\begin{array}{l}\text { - Study farms } \\
\text { B Keskim. } \\
\text { Aver. }\end{array}$ & $\begin{array}{c}\text { Kainuun } \\
\text { mh-lautak. } \\
\text { Forestry } \\
\text { board }\end{array}$ & $\begin{array}{l}\text { Suomus- } \\
\text { salmen } \\
\text { valtion } \\
\text { metsä } \\
\text { State } \\
\text { Forests }\end{array}$ \\
\hline
\end{tabular}

\begin{tabular}{|c|c|c|c|c|c|}
\hline I A & - & - & - & 0.3 & · \\
\hline 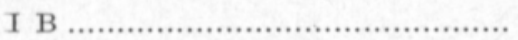 & 8.0 & 12.7 & 10.3 & 30.0 & 75.75 \\
\hline VT, EVT ........... & 70.8 & 60.3 & 65.7 & 32.6 & 61.94 \\
\hline III & 17.0 & 20.7 & 18.8 & 26.9 & 40.35 \\
\hline \multirow{2}{*}{ 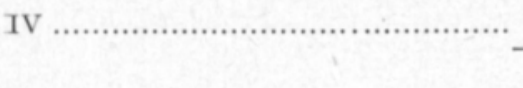 } & 4.2 & 6.3 & 5.2 & 10.2 & 9.18 \\
\hline & 100.0 & 100.0 & 100.0 & 100.0 & 187.22 \\
\hline
\end{tabular}

$\begin{array}{lllll}\text { Verokuutio - Taxed volume increment } & 1.84 & 1.83 & 1.83 & 1.87\end{array}$

Taulukosta 6 selviää tutkimustilojen puuston keskikuutio ja keskimääräinen kasvu asutustilojen perustamisvaiheessa tehtyjen arvioiden mukaan. Keskimäärät on saatu todennäköisesti koko metsäalan vastaavista tiedoista. Käyttämällä huonokasvuisen metsän kohdalla valtion hoitoalueen keskiarvoja on arvioitu suluissa esitetyt luvut kasvullisen metsämaan osalta.

Taulukko 6. Keskikuutio ja keskimääräinen kasvu k-m³/ha asutustilojen perustamisvaiheessa. Table 6. Average volume and average increment, $k-m^{3} / h a$.

\begin{tabular}{|c|c|c|c|c|c|}
\hline , & Tutkimustilat & $\begin{array}{l}t-S t \\
\text { B }\end{array}$ & $\begin{array}{c}\text { Keskim. } \\
\text { Aver. }\end{array}$ & $\begin{array}{l}\text { Kainuun } \\
\text { MHL } \\
\text { Forestry } \\
\text { Board }\end{array}$ & $\begin{array}{c}\text { Suomus- } \\
\text { salmen } \\
\text { valtion } \\
\text { metsä } \\
\text { State } \\
\text { Forest }\end{array}$ \\
\hline Keskikuutio - Av. volume .............. & 99.2 & 81.1 & 90.0 & 69 & 87 \\
\hline kasvullista - productive .............. & $(126)$ & (108) & (116) & 86 & 111 \\
\hline huonokasv. - unproductive ............ & $(18)$ & $(18)$ & (18) & 17 & 18 \\
\hline Keskim. kasvu $-A v$. increment ........ & 1.39 & 1.37 & 1.38 & $(1.67)$ & 1.70 \\
\hline kasvullisella ............................. & $(1.68)$ & $(1.63)$ & $(1.66)$ & 2.1 & 2.20 \\
\hline huonokasv. ................................ & $(0.5)$ & $(0.5)$ & $(0.5)$ & 0.6 & 0.50 \\
\hline
\end{tabular}




\section{Tutkimustilojen pellot ja viljelykelpoinen maa}

Tutkimustiloilla oli vuoteen 1963 mennessä raivattu peltoa kaikkiaan 167 ha ja laidunta 5 ha. Niillä oli tämän lisäksi vielä viljelykelpoiseksi arvosteltua maata 650 ha. Kivennäismaata on näissä ryhmissä yhteensä 310 ha ja turve maata 512 ha.

Aluetta varten laaditusta viljelykelpoisuuskartasta on voitu selvittää, että nyt olemassa olevat pellot ja jäljellä oleva viljelykelpoinen maa on viljelyarvonsa puolesta sijoitettu eri luokkiin seuraavan taulukon mukaisesti.

Taulukko 7. Pellon ja viljelykelpoisen maan luokittelu viljelyarvon puolesta, ha.

Table 7. The classification of the present arable land and cultivable land according to site quality, ha.

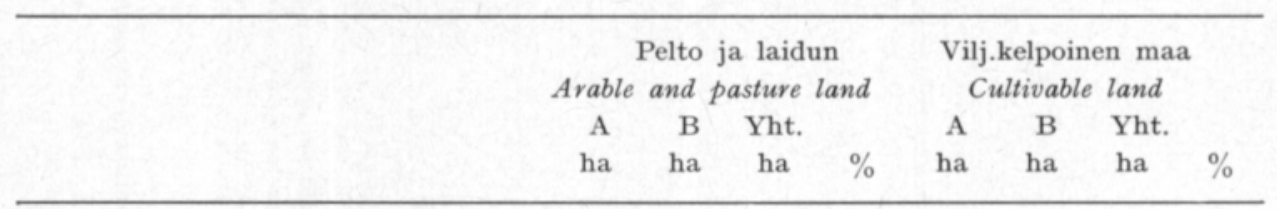

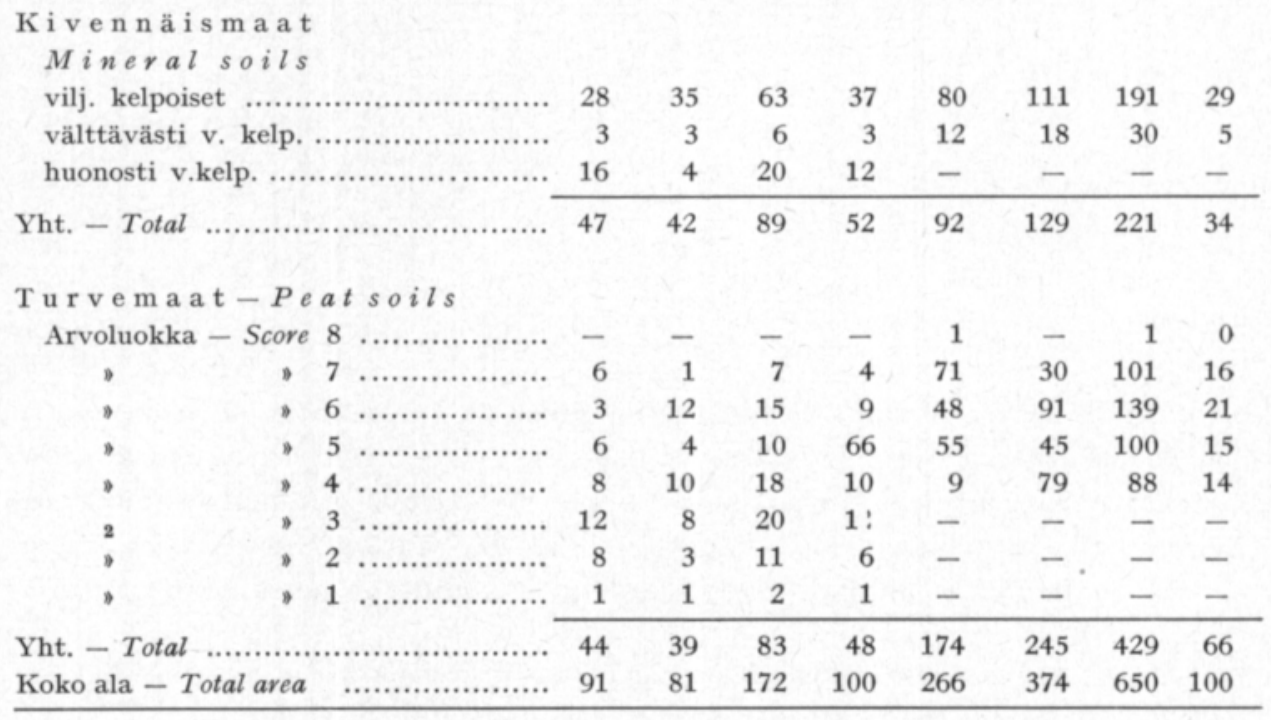

Taulukon 7 perusteella on pääteltävissä, että viljelysmaiden raivauksessa ei kovin paljon ole kiinnitetty huomiota viljelykelpoisuustutkimuksen tuloksiin. Niinpä kivennäismailla yli neljännes peltoalasta on raivattu välttävästi tai huonosti viljelykelpoiselle maalle. Turvemaille raivatusta pellosta n. $40 \%$ on tullut alalle, jolla viljelykelpoisuusarvo on arvosteltu boniteettiluvulla 3 tai sitä pienemmällä. Jäljellä oleva viljelykelpoinen maa näyttää keskimäärin kuuluvan parempiin luokkiin kuin tähän mennessä raivattu.

Aikaisemmin esitetystä taulukosta 2 selviää tutkimusajankohdan peltojen ja jäljellä olevan viljelykelpoisen maan jakautuminen maalajin mukaan.

Taulukkoa tarkasteltaessa selviää, että tiloille tähän mennessä raivattu pelto ja pysyvä laidun on sijoittunut hieman yli puoliksi kivennäismaille, 
joiden viljelyyn ottaminen nähtävästi on katsottu kiireellisemmäksi kuin turvemaiden. Jäljellä olevasta viljelykelpoisesta maasta on n. 1/3 kivennäisja $2 / 3$ turvemailla.

\section{Tutkimustilojen hehtaarisadot vv. 1959-64 sekä väkilannoitteiden ja maa- talouskalkin käyttö}

Tutkimustilojen hehtaarisatojen sekä väkilannoitteiden ja maatalouskalkin käyttömäärien selvittäminen katsottiin eräiksi v. 1959 alullepannun päätutkimuksen tärkeimmistä perustehtävistä. Tarkoitusta varten järjestettiin neljällä eri puolella Suomea olevalla pääalueella sadontarkkailu, jossa erityisesti palkattujen asiamiesten ja viljelijäin yhteistyöllä pyrittiin saamaan mahdollisimman luotettavat tiedot tärkeimpien viljelykasvien pinta-aloista ja sadoista viiden peräkkäisen vuoden aikana (1959-1963). Tehtävän suoritusta on yksityiskohtaisesti selostettu LAsolan v. 1965 julkaisemassa tutkimuksessa (LASola 1965, mm. p. 41-49, 119-124, 131-138, 145).

Mainitussa tutkimusjulkaisussa on esitetty eräitä tietoja, mm. keskimääräisestä rehuyksikkösadosta myös asutusalueittain (esim. LAsolA, 1965, p. 98). Suomussalmen tutkimustilaț esiintyvät tässä kahdella asutusalueella, jotka itse asiassa ovat välittömästi toisiinsa liittyviä.

Kun v. 1959 Pohjois-Suomen tutkimusalueella ei yleensä saatu tietoja kaikilta tutkimustiloilta, suoritettiin Suomussalmenkin tutkimusalueella v. 1965 tehdyn matkan yhteydessä täydentäviä tiedusteluja, joissa selviteltiin lähinnä vuoden 1964 satotuloksia. Näin on kaikkiaan 6 tilalta käytettävänä 6 vuoden, 10 tilalta 5 vuoden, 3 tilalta 4 vuoden ja kahdelta vain 2 vuoden sato- ja lannoitustiedot. Näiden täydennysten johdosta eivät esillä olevan tutkimuksen luvut kaikissa suhteissa täsmää LAsolan mainitun julkaisun lukujen kanssa. Tämä koskee myös viljelmittäisiä keskipeltoaloja, jotka puheenaolevana jaksona ovat nopeasti kasvaneet uudisraivauksien johdosta. Vuotuinen lisäys on keskimäärin 0.51 ha tilaa kohden.

Tutkimusalueen sato- ja lannoitustiedot esitetään vuosittain ja kuuden vuoden keskiarvoina taulukossa (8). Keskiarvot on tässä julkaisussa omaksuttua tapaa noudattaen esitetty, paitsi kaikkien tilojen, myös keskitasoa korkeampia satoja saaneesta A-ryhmästä ja keskitasoa alempia satoja saaneesta B-ryhmästä.

Todettakoon vielä, että rehuyksikkösadot hehtaarilta vaihtelivat tutkimuksessa yksityisillä tiloilla 1501 ja 2122 rehuyksikön välillä. Hehtaarisatojen riippuvuutta maan boniteetista ja lannoituksesta tarkastelemme alempana. 
Taulukko 8. Tutkimustilojen keskimäåräiset hehtaarisadot, kg ja ry, sekä lannoitteiden ja maatalouskalkin käyttö (ravinteina), kg/ha.

Table 8. Average crop yields in $\mathrm{kg}$ per ha and the use of fertilizers and lime (plant nutrients) on the study farms.

\begin{tabular}{llllllll}
\hline 1959 & 1960 & 1961 & 1962 & 1963 & 1964 & Keskim. \\
\hline
\end{tabular}

Rehuvilja - Barley and oats

$\begin{array}{llllllll}\text { A } \ldots \ldots \ldots \ldots \ldots \ldots \ldots \ldots \ldots & 1040 & 1680 & 1910 & 300 & 1790 & 1740 & 1+10 \\ \text { B } \ldots \ldots \ldots \ldots \ldots \ldots \ldots \ldots \ldots \ldots \ldots \ldots \ldots \ldots & 1160 & 1740 & 1710 & 300 & 2210 & 1780 & 1480 \\ \text { Kesk. } \ldots \ldots \ldots \ldots \ldots \ldots \ldots \ldots & 1100 & 1710 & 1810 & 300 & 2000 & 1760 & 1450\end{array}$

Heinä - Hay

\begin{tabular}{|c|c|c|c|c|c|c|c|}
\hline 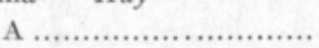 & 4420 & 4520 & 4800 & 4900 & 4090 & 4060 & 4470 \\
\hline 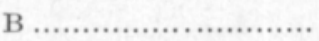 & 4600 & 4180 & 3700 & 3620 & 3690 & 3780 & 3930 \\
\hline Kesk. ..................... & 4590 & 4350 & 4250 & 4260 & 3890 & 3920 & 4200 \\
\hline
\end{tabular}

Peruna - Potato

\begin{tabular}{|c|c|c|c|c|c|c|}
\hline 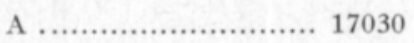 & 23040 & 16580 & 10250 & 23170 & 8890 & 16490 \\
\hline 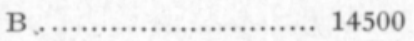 & 21920 & 12230 & 7150 & 18000 & 12600 & 14400 \\
\hline ... 15770 & 22480 & 14410 & 8700 & 20590 & 10750 & 15450 \\
\hline
\end{tabular}

Rehuyksiköitä - Fodder units per ha

\begin{tabular}{|c|c|c|c|c|c|c|c|}
\hline A. . & 1820 & 2130 & 2180 & 1610 & 1860 & 1910 & 1920 \\
\hline 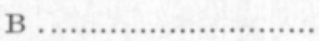 & 1850 & 2010 & 1790 & 1260 & 1650 & 1840 & 1730 \\
\hline Kesk. ....................... & 1830 & 2070 & 1990 & 1440 & 1760 & 1880 & 1830 \\
\hline
\end{tabular}

Lannoitteissa annettu kasvinravinteita, $\mathrm{kg} / \mathrm{ha}-$ Plant nutrients

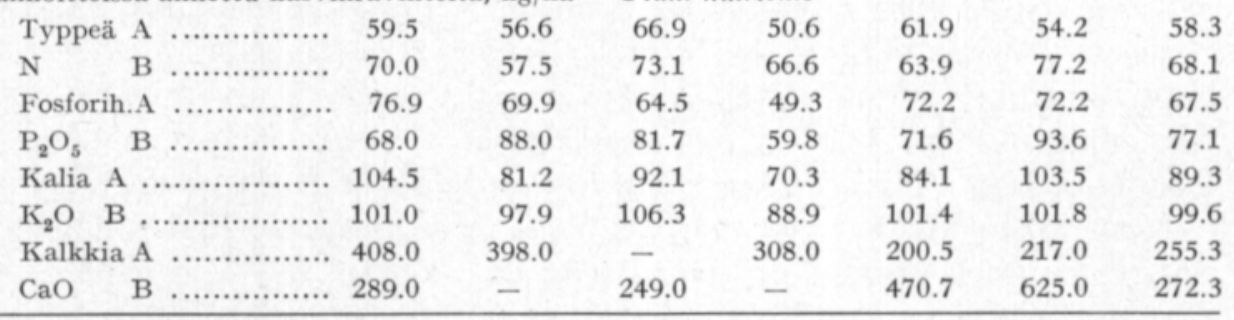




\section{Tutkimustilojen rakenteellista tarkastelua}

Edellisen perusteella voidaan laskea, että tutkimustilojen tilusalat olivat tutkimusajankohtana keskimäärin molemmissa ryhmissä seuraavat:

\begin{tabular}{|c|c|c|c|}
\hline & Tutl & tilat - & dy farms \\
\hline & A & B & Keskim \\
\hline & ha & ha & ha \\
\hline Peltoa ja laidunta - Field and pasture... & 9.1 & 8.1 & 8.6 \\
\hline Kasvullista metsää - Productive fores ........................ & 79.1 & 84.1 & 81.6 \\
\hline Huonokasvuista metsää - Unproductive forest ................ & 25.8 & 24.3 & 25.0 \\
\hline 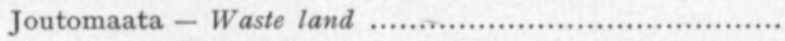 & 36.0 & 39.3 & 37.7 \\
\hline 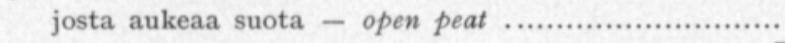 & 3.3 & 1.2 & 2.0 \\
\hline & 150.0 & 155.8 & 152.9 \\
\hline
\end{tabular}

Eri tilojen peltoalat vaihtelivat 4.6 ja 14.3 ha:n välillä

Tilusten jakaantumisesta ja sijainnista antavat kuvan seuraavat keskiarvot.

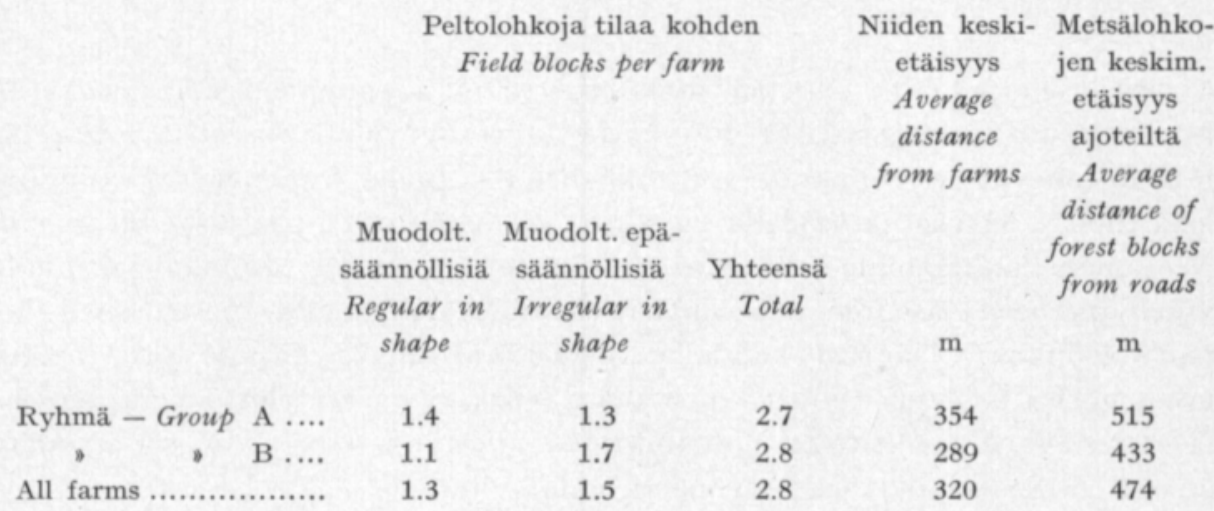

Kuten sodan jälkeen perustetuilla asutustiloilla yleensä, tilussuhteet tutkimustiloilla ovat verraten tyydyttäviä. Peltojen keskietäisyyksissä on kuitenkin melkoista tilakohtaista vaihtelua. Lyhimmät peltojen keskietäisyydet ovat $150 \mathrm{~m}$, pisimmät n. $530 \mathrm{~m}$. Metsälohkojen etäisyydet ajoteiltä vaihtelevat $250 \mathrm{~m}$ ja $800 \mathrm{~m}$ välillä. 
Tutkimustilojen sijainti asutustaajamiin nähden on huomattavan epäedullinen. Lähimmät varsinaiset kaupankäyntikeskukset ovat Ämmänsaari $(20 \mathrm{~km})$ ja Suomussalmen kirkonkylä $(25 \mathrm{~km})$. Rautatieasema on Ämmänsaaressa, mutta meijerikuljetukset suoritetaan aina Kajaaniin saakka (110 $\mathrm{km})$.

Tutkimustiloilla on asutushallituksen piirustusten mukaan rakennetut asuinja kotieläinrakennukset. Viimeksimainitut ovat useimmissa tapauksissa tyyppiä, jossa on varattu tila 9 lypsylehmälle ja yhteensä 16 nautayksikölle. Tällaisen rakennuksen rakentamiskustannus on v. 1961 hintojen mukaan arvioitu 23000 nykymarkaksi (Finnish Study Group 1969, p. 69). Vain harvassa tapauksessa on navetan yhteyteen rakennettu säilörehutorni. Sähköverkostoa ei tutkimusajankohtana ollut rakennettu alueelle.

\section{Tietoja viljelijäperheistä ja työn käytöstä}

V. 1963 saatiin seuraavia tietoja tutkimustilojen viljelijäperheistä ja niiden ikärakenteesta. Haastattelussa tavoitettiin 7 A-ryhmään ja 9 B-ryhmään kuuluvaa viljelijäperhettä.

\begin{tabular}{|c|c|c|c|}
\hline $\begin{array}{l}\text { Viljelmällä asuvat viljelijäperheen jäsenet ja sukulaiset } \\
\text { The members of farmer family living on the farm }\end{array}$ & $\begin{array}{c}\text { Ryhmä } \\
\text { Group } \\
\text { A }\end{array}$ & $\begin{array}{c}\text { Ryhmä } \\
\text { Group } \\
\text { B }\end{array}$ & $\begin{array}{l}\text { Keskim. } \\
\text { Aver. }\end{array}$ \\
\hline Miehiä - Men ............................................ & 2.4 & 1.6 & 1.9 \\
\hline niistä nuorukaisia (16 v.) - Youths ........... & $(1.4)$ & $(0.6)$ & $(0.9)$ \\
\hline Naisia - Women (mukana 16 v.) ........................ & 1.1 & 1.7 & 1.4 \\
\hline Lapsia - Children (alle 16 v.) .......................... & 2.3 & 2.3 & 2.3 \\
\hline Isännän keski--ikä - Aver. age of the farmer ................ & 47.8 & 50.3 & 49.3 \\
\hline Emännän $\quad-\quad, \quad$ the housewife ................ & 47.7 & 49.3 & 48.5 \\
\hline 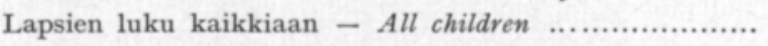 & 5.4 & 4.6 & 4.9 \\
\hline Näistä asuu todennäk. muualla - Living elsewhere .......... & 1.6 & 1.6 & 1.3 \\
\hline
\end{tabular}

Edellisen pohjalta näyttää siltä, että isännän apuna on noin yhdeksällä kymmenestä tutkimustilasta 16 vuotta täyttänyt poika ja että tyttäretkin muodostanevat työvoimareserviä ehkä neljällä tilalla kymmenestä. Yli puolella tiloista on yksi ja vajaalla puolella kaksi varttuneempaa lasta maailmalla.

Saman haastattelun yhteydessä tiedusteltiin tiloilta isännän ja muiden viljelijäperheen jäsenten sekä myös vieraiden viljelmällä suorittamien työpäivien lukua. Isännän kohdalla tiedusteltiin myös ansiotöissä viljelmän ulkopuolella tehtyjen työpäivien lukua. Seuraavassa asetelmassa on perheenjäsenten työpäivät esitetty muunnettuina miestyöpäivinä (1 naisen työpäivä on $0.8 \mathrm{mmp}$ ja alaikäisen työpäivä $=0.5 \mathrm{mmp}$ ).

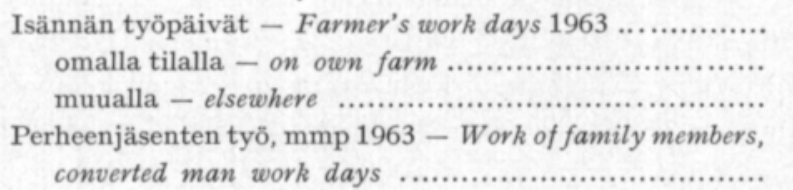

A B Kaikkitilat

$\begin{array}{rrr}231 & 264 & 253 \\ 51 & 36 & 43 \\ 599 & 485 & 535\end{array}$


Isäntien maatilalla suorittama työ jakaantuu vallitsevan tavan mukaan enimmäkseen pellonviljelyn ja metsätalouden kesken. Perheenjäsenten työstä lienee melkoinen osa kotitalouden työtä, mikä tavan mukaan on laskettu viljelmän työksi, mutta kotieläinten hoito ja osallistuminen kiirekausien peltotöihin käsittänee enemmän kuin puolet lukujen osoittamasta työmäärästä. Kun 16 vuotta täyttäneet nuorukaiset usein osallistuvat myös metsätöihin, sisältyy lukuihin myös metsätalouden hyväksi tehtyä työtä.

\section{Hevos- ja traktorityö tutkimustiloilla}

Tutkimustiloilla oli tiedustelun ajankohtana omia hevosia ja traktoreita (keskim. tilaa kohden kpl):

\begin{tabular}{|c|c|c|c|}
\hline & A & B & $\begin{array}{c}\text { Keskim. } \\
\text { Aver. }\end{array}$ \\
\hline ysikasv. hevosia - Adult horses & 0.6 & 0.4 & 0.5 \\
\hline aktoreita - Tractors & 0.6 & 0.6 & 0.6 \\
\hline
\end{tabular}

Hevosten ja traktorien käyttö viljelmällä ja ansiotyössä viljelmän ulkopuolella on tiedusteluun saatujen vastausten mukaan tiedusteluajankohtana päättyneen vuoden kuluessa ollut seuraava (laskettu kussakin tapauksessa vain tiloilta, joilla on oma hevonen tai traktori):

\begin{tabular}{|c|c|c|c|}
\hline & A & B & $\begin{array}{c}\text { Keskim. } \\
\text { Aver. }\end{array}$ \\
\hline \multicolumn{4}{|l|}{ Oman hevosen tyōpäiviä - Horse days } \\
\hline 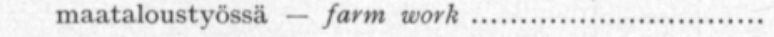 & 28 & 28 & 28 \\
\hline metsätyössä - forest work …….......................... & 41 & 22 & 32 \\
\hline ansiotyössä - outside work .................................. & 8 & 8 & 8 \\
\hline \multicolumn{4}{|l|}{ Oman traktorin työtä tuntia - Tractor hours } \\
\hline omalka viljelmällä - on own farm ......................... & 271 & 164 & 207 \\
\hline 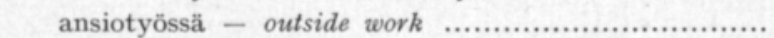 & 85 & 48 & 63 \\
\hline
\end{tabular}

Esitetystä selviää, että viljelmien hevosia ja traktoreita on vain suhteellisen vähän käytetty ulkopuolisessa ansiotyössä.

\section{Maidontuotantoa koskevat tiedot}

Tutkimustilojen maidontuotannosta antavat kuvan osaksi toimitukset meijeriin (Kajaanin osuusmeijeri), osaksi karjantarkkailun tulokset, joita on noin puolelta tiloista. Meijeriltä saatujen kuukausitietojen perusteella lasketut tilottaiset keskiarvot talousvuosilta $1959 / 60-1963 / 64$, ja tuotannon kausiluontoisuuden selvittämiseksi myös kesäkauden tuotannot (kesä-elokuu) on tutkituista tilaryhmistä esitetty erikseen taulukossa 9. 
Taulukko 9. Tutkimustilojen maidon toimitukset Kajaanin osuusmeijeriin talousvuosittain ja vastaavina kesäkausina, $\mathrm{kg}$.

Table 9. Average milk deliveries of the study farms to provincial dairy, by economic years and by respective summer seasons, $\mathrm{kg}$.

\begin{tabular}{lrrrrrr}
\hline & $1959 / 60$ & $1960 / 61$ & $1961 / 62$ & $1962 / 63$ & $1963 / 64$ & $\begin{array}{c}\text { Keskim. } \\
\text { Aver. }\end{array}$ \\
\hline & & & & & & \\
Ryhmä A & & & & & & \\
Vuosittain - Annually & 8158 & 9709 & 11479 & 11777 & 15356 & 11296 \\
VI-VIII & 2453 & 2914 & 3768 & 4099 & 5013 & 3649 \\
& & & & & & 10205 \\
Ryhmä B & & & & & & \\
Vuosittain - Annually & 7568 & 10462 & 10236 & 11823 & 10934 & 1020 \\
VI-VIII .................. & 2332 & 2717 & 3273 & 3738 & 3440 & 3100 \\
\hline
\end{tabular}

Keskiarvoissa on otettu lukuun vain maitoa lähettäneet tilat (yhteensä 19),

Toimitukset meijeriin eivät anna kuvaa koko maidontuotannosta, sillä maitoa on tuotettu myös kotitalouksien käyttöä ja suoraa myyntiä varten ja jokin määrä on juotettu vasikoille. Kotikäyttö on alueella arvioitu n. 2100 kiloksi ja suora myynti n. 400 kiloksi tilaa kohden (Finnish Study Group, p. 59).

Karjantarkkailutoimintaan osallistuneiden tilojen maidontuotanto sekä rehunkäyttö selviävät taulukosta 10 , johon on vertailua varten otettu myös kolmen maan pohjoisosan maatalouskeskuksen tarkkailukarjojen keskitulokset. Niiden ohella myös nähdään tuotosmääriltään yli ja alle keskiarvon olevien tarkkailukarjojen keskiarvot. 
Taulukko 10. Suomussalmen tutkimustilojen karjantarkkailuyhdistykseen kuuluvien karjojen tuotos- ja rehunkäyttöluvut keskim. 1959-63 sekä vastaavat tiedot kolmen pohjoisen maatalouskeskuksen alueelta, myōs jaoteltuna yli ja alle keskitason menevien karjojen kesken. Table 10. Average use of milk and fodder on the study farms being members of Milk Recording Societies 1959-63, and respective records of three northern Agricultural Societies, with reference to groups above $(A)$ and below $(B)$ average.

\begin{tabular}{|c|c|c|c|c|c|c|}
\hline & \multicolumn{3}{|c|}{$\begin{array}{l}\text { Kolmen pohj. seuran tarkkailu- } \\
\text { karjat - Milk recording herds } \\
\text { Kaikki Karjat - Herds } \\
\text { karjat yli keski- alle keski- } \\
\text { All arvon arvon } \\
\text { herds with prod. with prod. } \\
\text { over aver. under aver. }\end{array}$} & $\begin{array}{l}\text { Suomussa } \\
\qquad S \\
\text { Keskim. } \\
\text { Average }\end{array}$ & $\begin{array}{c}+ \text { tilat } \\
\text { Group } \\
\text { A }\end{array}$ & $\begin{array}{c}\text {-tilat } \\
\text { Group } \\
\text { B }\end{array}$ \\
\hline Maitoa - Milk, kg .............. & 3263 & 3655 & 2843 & 3501 & 3508 & 3491 \\
\hline Rasvaa - Fat, kg .............. & $\cdot$ & . & $\cdot$ & 170 & 172 & 167 \\
\hline \multicolumn{7}{|c|}{ Rehunkäyttō, ry - Use of fodder f.u. } \\
\hline Öljyväkirehu - Oil cakes ..... & 138 & 166 & 113 & 167 & 158 & 179 \\
\hline Viljaväkirehu - Grain ......... & 426 & 490 & 354 & 501 & 454 & 566 \\
\hline Heinää - Hay .................. & 1057 & 1048 & 1057 & 1054 & 1015 & 1110 \\
\hline Olkia - Straw ................... & 12 & 11 & 16 & 10 & 16 & 2 \\
\hline Väkevä tuorerehu - Roots etc. & 96 & 116 & 85 & 116 & 118 & 113 \\
\hline Täyttãvä tuorerehu - Silage & 64 & 80 & 47 & 114 & 122 & 102 \\
\hline Laidunta - Pasture ............ & 644 & 684 & 595 & 667 & 729 & 628 \\
\hline Yht. ry - Total, f.u. ........... & 2437 & 2595 & 2267 & 2629 & 2612 & 2700 \\
\hline $\begin{array}{l}\text { Lehmien elopaino, } \mathrm{kg}-\ldots . . . . \\
\text { Live weight, } \mathrm{kg}\end{array}$ & 376 & . & . & 393 & 385 & 404 \\
\hline
\end{tabular}

\section{Metsätaloussuunnitelmat ja niiden perusteet}

Taulukossa 6 (p. 353) esitettiin tutkimustilojen metsämaan puuston keskikuutio sekä keskimääräinen kasvu hehtaaria kohden perustamisvaiheessa suoritetun arvioinnin mukaan. Vertauskohdaksi on otettu Kainuun metsänhoitolautakunnan ja Suomussalmen valtionmetsien vastaavat luvut. - Kuten taulukosta nähdään, on keskikuutio tutkimustiloilla ollut suurempi kuin metsänhoitolautakunnan alueella ja Suomussalmen hoitoalueessa keskimäärin. Arvioitu keskikasvu on sitävastoin ollut pienempi.

Perustamisvaiheen puuston laadusta ei asiakirjoissa ole tarkkoja tietoja. Kuitenkin selviää niistä puuston jakaantuminen sahapuun ja ainespuun sekä polttopuun kesken seuraavasti (ha kohden ja \%):

\begin{tabular}{|c|c|c|c|c|}
\hline & $\begin{array}{c}\text { A-tilat } \\
\text { Group } A \\
\text { k-m }{ }^{3}\end{array}$ & $\begin{array}{c}\text { B-tilat } \\
\text { Group } B \\
\text { k-m } \text { m }^{3}\end{array}$ & $\begin{array}{c}\text { Keskim. } \\
\text { Aver. } \\
\text { k-m } \text { m }^{3}\end{array}$ & $\%$ \\
\hline Sahapuuta - Saw logs ................. & 26.47 & 17.38 & 21.86 & 24.3 \\
\hline Kuusipaperipuuta - Spruce pulp .... & 13.99 & 15.30 & 14.65 & 16.3 \\
\hline Mäntypaperipuuta - Pine pulp ...... & 20.43 & 19.07 & 19.74 & 21.9 \\
\hline Polttopuuta - Firewood ................. & 17.09 & 14.81 & 15.89 & 17.7 \\
\hline Vailla käyttömahd. - Waste ........... & 21.15 & 14.53 & 17.87 & 19.8 \\
\hline Yht. - Total ............................... & 99.15 & 81.09 & 90.01 & 100.0 \\
\hline
\end{tabular}


Suomussalmen valtionmetsissä on metsän puuston kuutiomäärästä ollut mäntyä $52.7 \%$, kuusta $33.0 \%$, koivua $12.9 \%$ ja muita puulajeja $1.4 \%$ (Linnamies 1959 , p. 185). Paperipuun määrän perusteella päädyttäisiin siihen, että tutkimustiloilla on mäntypuuta noin kolmannes enemmän kuin kuusta. Koska sahapuu saattaa olla enemmän mäntyvaltaista, voi valtionmetsissä esiintyvä suhde hyvinkin vastata olosuhteita myös tutkimustiloilla.

Tutkimustilojen puutavaran myynneistä on tietoja vuosilta $1950-1958$, jona aikana tilat ovat suurimmalta osalta olleet viljelijänsä käytössä ns. hallintasopimusten nojalla. Tilojen siirtyessä viljelijäin omistukseen on useimmille niistä laadittu Kainuun metsänhoitolautakunnan toimesta metsätaloussuunnitelma ja metsän myynnit ovat tämän jälkeen tapahtuneet metsänhoitolautakunnan suunnitelmaan perustuvien myyntileimausten perusteella. Tiedot suoritetuista leimauksista, jotka ovat käytettävissä vuosilta 1959-63, antavat todennäköisesti oikean kuvan myynteihin sisältyvistä puutavaramääristä näinä vuosina. Sitävastoin myyntitulot eivät tätä tietä tule kaikilta tiloilta selvitetyiksi, vaan ne on osaksi arvioitava hintatasosta käytettävissä olevia tietoja apuna käyttäen.

Puutavaran myynnit ja myyntileimaukset ovat käsittäneet mainittuina jaksoina vuotta ja perustamisajankohdan koko metsäalan hehtaaria kohden seuraavat määrät eri tavaralajeja $\left(\mathrm{j}^{3}\right.$ tai $\left.\mathrm{k}-\mathrm{m}^{3}\right)$ :

\begin{tabular}{cccccc} 
Ennen & \multicolumn{2}{c}{$1959-$ Before } & \multicolumn{3}{c}{$1959-63$} \\
A-tilat & B-tilat & Keskim. & A-tilat & B-tilat & Keskim. \\
Group A & Group B & Aver. & Group A & Group B & Aver. \\
31.1 & 25.3 & 28.2 & 36.5 & 25.3 & 30.8 \\
0.51 & 0.53 & 0.52 & 0.872 & 0.719 & 0.794 \\
0.40 & 0.28 & 0.34 & 0.594 & 0.521 & 0.557 \\
0.22 & 0.11 & 0.16 & 0.141 & 0.124 & 0.133 \\
\hline 2.07 & 1.69 & 1.97 & 2.64 & 1.83 & 2.33
\end{tabular}

Metsätaloussuunnitelmista käy mm. ilmi vuoden 1959 vaiheilla arvioitu puuston keskikuutio jäljellä olevalla metsäalalla, keskimääräinen vuotuinen kasvu ja hakkuusuunnite lähintä 10-vuotiskautta varten, jotka alempana olevassa asetelmassa on esitetty koko metsäalan hehtaaria kohden laskettuina.

\begin{tabular}{|c|c|c|c|}
\hline \multicolumn{3}{|c|}{ Tutkimustilat - Study farms } & $\begin{array}{l}\text { Suomussalm } \\
\text { hoitoalue }\end{array}$ \\
\hline $\begin{array}{c}\text { A-tilat } \\
\text { Group } A\end{array}$ & $\begin{array}{c}\text { B-tilat } \\
\text { Group B }\end{array}$ & $\begin{array}{c}\text { Keskim. } \\
\text { Aver. }\end{array}$ & $\begin{array}{r}\text { Forestry } \\
\text { district }\end{array}$ \\
\hline 89.5 & 84.8 & 87.2 & \\
\hline 106.6 & 98.7 & 100.7 & 87 \\
\hline 1.39 & 1.37 & 1.38 & 1.70 \\
\hline 2.70 & 2.82 & 2.76 & 2.59 \\
\hline
\end{tabular}

Kasvull. metsäala, ha $-\ldots \ldots \ldots \ldots$......

Productive forest area

Puuston keskikuutio, k-m ${ }^{3} / \mathrm{ha} . \ldots \ldots$....

Aver. timber stand

Keskim. kasvu. k-m $\mathrm{m}^{3} /$ ha

Aver. growth

Hakkuusuunnite, k- $\mathrm{m}^{3} / \mathrm{ha}$

2.70

Planned cuttings

Kehitysluokkajakaantuman mukainen arvio

Estimate based on development classes

Puuston keskikuutio - Aver. timber st.

Keskim. kasvu - Aver. growth 
Metsätaloussuunnitelmia laadittaessa selvitettiin $\mathrm{mm}$. raivausten jälkeisen metsäalan jakaantuminen kehitysluokkiin OsARAn (1948) ehdottamalla tavalla. Tämä jakaantuma kummassakin tutkimustilojen ryhmässä on esitetty Taulukossa 4 (p. 352). Taulukkoon on otettu Linnamienen (1959, p. 195) vastaavat luvut Suomussalmen hoitoalueesta. Linnamienen tutkimuksesta on saatu myös valtionmetsän puuston keskikuutiot ja keskikasvut, joilla saattaa olla mielenkiintoa tuotosarvioita laadittaessa. Niiden perusteella on laskettavissa, että tutkimustilojen kasvullisen metsän keskikuutio ja kasvu olisivat ylläolevan asetelman kahdella alimmalla rivillä olevien lukujen mukaisia, jos lukuja sovelletaan niiden jakautumaan. Asetelmassa on vertailun vuoksi esitetty myös Suomussalmen hoitoalueen puusto- ja kasvuarviot sekä hakkuusuunnite alkavaa kymmenvuotiskautta varten (Linnamies, 1959, p. 216). Kiertoaika on tässä suunnitelmassa edellytetty 120 vuotiseksi ja seuraavan 10-vuotiskauden hakkuu $247 \mathrm{k}-\mathrm{m}^{3}$ : ksi vuotta kohden.

Kuten huomataan, metsätaloussuunnitelmissa hakkuusuunnitteet oli asetettu vuotuisia kasvumääriä korkeammiksi. Tämä johtuu tietenkin vanhempien ikäluokkien suhteellisesti suuresta laajuudesta kasvullisella metsämaalla. Nuorempien ikäluokkien pinta-alat (erityisesti harvennusmetsiköt, kehitysluokka 2) ovat siinä määrin pieniä, että hakkuusuunnitteita on muutamien vuosikymmenien kuluttua voimakkaasti supistettava.

Puutavaran myyntiarvot tilaa ja kasvullisen metsämaan hehtaaria kohden vv. 1953-58 selviävät allaolevan asetelman ensimmäiseltä riviltä. Vuosien 1959-63 myyntiarvot on laskettu leimauksessa selvitettyjen puutavaramäärien ja Kainuun keskihintojen mukaan, hakkuusuunnitteen myyntiarvot 1959-63 keskihintoja käyttäen, edellyttäen puukuutiometrin rakenne samaksi kuin leimauksissa $1959-63$.

\begin{tabular}{|c|c|c|c|c|c|}
\hline \multirow[b]{2}{*}{ Myynnit - Sales ........................... } & Tilaa & len - & er farm & \multicolumn{2}{|c|}{$\begin{array}{l}\text { Kasvull.metsäalan } \\
\text { ha kohden } \\
\text { Per ha of prod. } \\
\text { forest land } \\
\text { mk }\end{array}$} \\
\hline & A & & $\begin{array}{l}\text { Kesk. } \\
\text { Aver. }\end{array}$ & A : & \\
\hline $1953-58$ (vallinnein hinnoin) ........... & 2787 & 2231 & 2509 & $33: 28$ & $25: 24$ \\
\hline 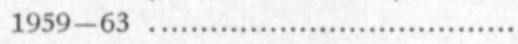 & 3485 & 2389 & 2937 & $38: 94$ & 28:17 \\
\hline Hakkuusuunnite - Cutting plan ....... & 3564 & 3683 & 3589 & $39: 82$ & $43: 43$ \\
\hline
\end{tabular}

\section{Aikaisempia laskelmia tutkimustilojen taloudellisista tuloksista}

Alueen tutkimustilojen todennäköisistä taloudellisista tuloksista vv. 195963 on esitetty arvioita tutkijaryhmän toistaiseksi vain englanninkielisenä monisteena julkaistussa pääraportissa (Finnish Study Group, 1969). Tilojen 
maidontuotos on arvioitu lisäämällä meijeriin toimitettuun maitomäärään kulutustutkimusten mukainen kotikulutus. Maito on hinnoiteltu meijerin maksaman tilityshinnan mukaan. Tiloilla on oletettu tuotetun naudanlihaa määrä, joka normaalisti on voitu tuottaa rehusadosta lypsylehmien ja hevosen tarpeen ylittävällä markkinattoman rehun määrällä. Metsätaloudessa käytettyjen hevospäivien arvo ja valtion maksama lehmäavustus on edelleen otettu huomioon kotieläintulona; kasvinviljelytuotteista on laskettu olevan tuloja vain perunasta. Kustannuksista on väkilannoitemenot selvitetty tiloilta saadun informaation perusteella; väkirehun hankinnat on arvioitu lasketun tarpeen perusteella, kun taas useimmat muut kustannuserät on arvioitu vastaavan suuruusluokan kirjanpitotilojen hehtaaria kohden laskettujen vastaavien kustannussummien nojalla.

Metsätalouden tuotto on mainitussa selvityksessä arvioitu metsätyypeittäin käyttäen hyväksi päämetsätyypeistä alueittain laadittuja kasvu- ja tuottotaulukoita. Kainuun osalta on ollut käytettävissä ILvessalon (1967) luonnonnormaalien metsiköiden kehitystä koskeva uusi tutkimus. Koska tutkimuksen koealat edustavat tuottoisampaa tasoa kuin mikä alueella esiintyy valtakunnan metsien linja-arvioinnin mukaan, on keskimääräistä kestävää hakkuutuloa arvioitaessa tehty $30 \%$ :n vähennys ILvEsSALon tutkimuksen perusteella arvioituihin lukuihin (vrt. Finnish Study Group 1969, p. 91, alav., p. 92). Hintoina on sovellettu alueella vv. 1959-63 maksettuja tukki- ja paperipuun kantohintoja, hakkuuansioina alueella voimassa olevien työehtosopimusten mukaisia palkkoja; työsaavutukset on arvioitu samoin kun alempana tässä tutkimuksessa.

Tutkimustilojen edellämainitulla tavalla arvioidut tuotot ja kustannukset ovat seuraavat. Palautettakoon tässä mieleen, että tiloilla on keskimäärin peltoa 7.9 ha, kasvullista metsää 86.1 ha ja lypsylehmiä 4.4.

\begin{tabular}{|c|c|c|}
\hline \multicolumn{3}{|l|}{ Kokonaistuotto - Gross return } \\
\hline 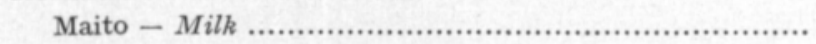 & 609 & 4799 \\
\hline Hevostyō metsätaloudessa - Horse days ..................... & 67 & 530 \\
\hline Naudanliha - Beef .............................................. & 209 & 1646 \\
\hline 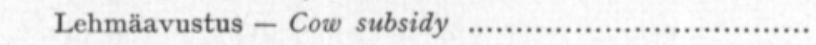 & 26 & 205 \\
\hline \multirow[t]{2}{*}{ 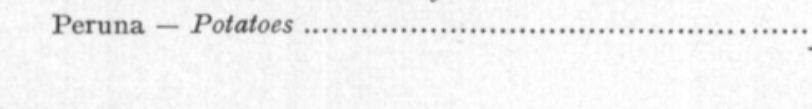 } & 30 & 236 \\
\hline & 941 & 7416 \\
\hline \multicolumn{3}{|l|}{ Liikekustannukset - Operating costs } \\
\hline 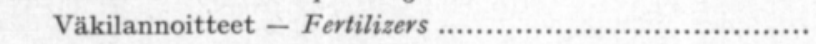 & 135 & 1064 \\
\hline 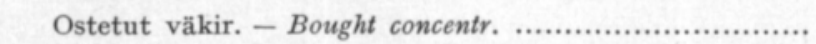 & 67 & 527 \\
\hline 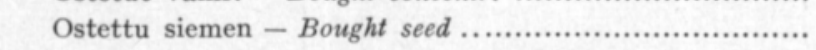 & 7 & 55 \\
\hline Koneet ja vetov. - Machines \& tract. power ................. & 72 & 567 \\
\hline 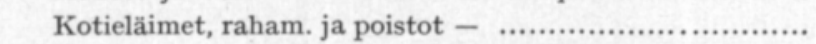 & 64 & 504 \\
\hline \multicolumn{3}{|l|}{ Livestock, money expenses \& depreciation } \\
\hline 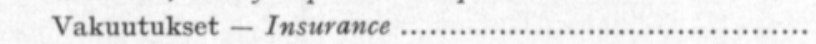 & 11 & 87 \\
\hline 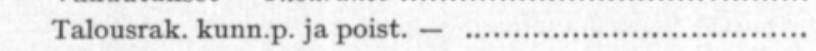 & 66 & 520 \\
\hline \multicolumn{3}{|l|}{ Repairs \& deprec. of economy build. } \\
\hline & 422 & 3324 \\
\hline
\end{tabular}




$\begin{array}{cc}\text { mk } & \text { mk } \\ \text { ha kohden } & \text { tilaa kohden } \\ \text { par ha } & \text { per farm }\end{array}$

Katetuotto (korv. työlle ja kiint. pääomalle) .................... 587

4628

Gross margin to work and capital

Työtunteja - Working hours

Katetuotto työtunt. kohti - mk

Gross margin per working hour

M e t s a t a 10 us - Forestry (per ha prod. forest)

Kantorahatuloja - Stumpage income

Hankintatyöansio - Earning of logging and hauling

Todelliset hakkuutulot ovat tutkimustiloilla selvityksen kohteena olleen 5-vuotiskauden aikana olleet suurempia kuin taulukossamme esitetty kestävä hakkuutulo. Kuten sivulla 363 olevasta asetelmasta käy ilmi, kantorahatulot on myyntileimausten ja alueella saatujen keskihintojen mukaan laskettuna olleet 33: 39 kasvullisen metsämaan hehtaaria kohden. Hakkuusuunnitteiden perusteella päästään vielä korkeampaan arvoon 41: 68. Näitä lukuja soveltaen ja edellyttäen että hankintatyöansio on samassa suhteessa kantohintatuloon kuin edellä, tullaan seuraaviin tilakohtaisiin lukuihin.

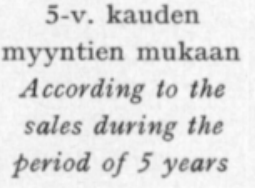

Kantorahatulo tilaa kohden - Stumpage income ....... Työtulo $\quad$ - $\quad$ Labour income ........... Kokonaistulo (maatalouden katetuotto) ................. Total gross margin
Hakkuusuunnitteen mukaan According to the cutting plan

3588

2812

11028

Näiden tulojen saaminen on vastaavalla tavalla arvioiden edellyttänyt todellisten myyntien perusteella laskettuna 1225 työtunnin, hakkuusuunnitteen mukaisten myyntien mukaan 1529 työtunnin suoritukset. Tilan koko työnkäyttö olisi ollut vastaavasti 3312 tai 3616 työtuntia. Tämä ei vielä ylitä avioparin muodostaman työkykyisen perheen omaa kapasiteettia.

Kun otetaan huomioon, että uudistamisiässä olevat puustot käsittävät noin kolmanneksen ja vajaatuottoiset ja siis tästä syystä uudistettavat $n$. viidenneksen koko kasvullisen metsän alasta, on luonnollista, että tutkimusajan suunnitelman mukaiset hakkuut ylittävät kestävän hakkuun määrät. Jotta viljelijät voisivat tulevaisuudessa ylläpitää sen tulotason, johon ovat metsänmyyntitulojen perusteella tottuneet, on heille välttämätöntä pyrkiä lisäämään maataloustuotannosta saatavaa tuloa. Vilkas uudisraivaustoiminta ja karjan lisääminen olivat siten täysin ymmärrettäviä, etenkin kun valtiovalta oli luonut lisäkiihokkeita $\mathrm{mm}$. raivauspalkkioiden muodossa. 


\section{Maatalouden tuotantosuunnan perusteita}

\section{Maan lannoitustarve ja sadot}

Maataloustuotannon suunnittelussa on eri viljelykasveista erilaisella lannoituksella saatavien satojen arviointi eräs eniten tuloksiin vaikuttavista, mutta samalla käytännössä vaikeimmista tehtävistä. Maaperän ja mikroilmaston vaihtelut ovat maamme olosuhteissa verraten pienilläkin alueilla huomattavia ja kun lisäksi maa jakaantuu monille viljelijöille, joilla erilaisten tottumustensa ja taloudellisten edellytystensä vuoksi on erilaisia viljelytapoja, hehtaarisadot samanlaisina vuosinakin ovat usein suuresti toisistaan poikkeavia. Sääsuhteista riippuvat vuotuiset satovaihtelut ovat myöskin suuria, ja myöskin lannoitteiden vaikutus on erilainen erilaisina vuosina.

Kannattavan pellonviljelyn edellytyksenä pidetään maassamme yleensä lannoitusta. Sekä karjanlannan että erilaisen väkilannoituksen käytöllä saatavia sadonlisäyksiä on kenttäkokeilla jo varsin laajasti tutkittu (vrt. esim. Väkilannoitteet maataloutemme kohottajina 1955 p. $119-125$, PEssi 1965 , p. 48-68). Viime vuosina on entistä enemmän kiinnitetty huomiota myöskin taloussuunnittelun kannalta erittäin tärkeään kysymykseen nousevien lannoitemäärien vaikutuksesta (SALONEN ja TAINio 1957, 1961, SALONEN et al. 1962). Äskettäin on myös julkaistu regressioanalyysiin perustuva tutkimus erilaisten maaperällisten, ilmastollisten ym. tekijäin erillisistä vaikutuksista heinänurmien satotuloksiin (SoINI 1966).

Erilaisten turvemaiden satoja ja niiden riippuvuutta lannoituksesta ovat mm. VALMARI (1956 ja 1957) ja PUUSTJÄRvi $(1959,1960)$ valaisseet varteen otettavilla tutkimuksilla. Isotalon - (Maatal. Tutk.keskus1962-64) suorittamat kenttäkokeet Perä-Pohjolan koeasemalla Rovaniemellä täydentävät näistä saatua kuvaa, erityisesti nousevien lannoitemäärien käytön kokonaisvaikutuksen selvittämisessä.

Myöskin uudismailla suoritetun lannoituksen vaikutuksia on tutkittu, tosin suhteellisesti harvojen kenttäkokeiden perusteella (РонJAKallio 1933, SALONEN 1963, vrt. myös äskenmainitut SALOSEN ym. julkaisut).

Esillä olevan tutkimuksen kannalta olisi tärkeintä selvittää, millaisia satoja Kainuussa olevalla tutkimusalueellamme keskimäärin saavutetaan viljelykseen otetuilla ja otettavaksi aiotuilla maaperätyypeillä erilaisilla lannoitemäärillä. Tutkimuksemme tässä suhteessa voi nojautua osaksi edellämainittuihin koetuloksiin, osaksi tutkimustiloilta vv. 1959-64 suoritettuun sato- ja lannoitemäärien tarkkailuun. 
Kuitenkin on alueen moreenimailla suoritetuista lannoituskokeista niin vähän tuloksia käytettävissä, että näiden maiden satotuloksista ei tätä tietä voida saada mitään selvää käsitystä. Oma tutkimusaineistomme viittaa siihen suuntaan, että alueella yleisimmin viljelty kevätvilja (ohra) pääasiassa tuotetaan kivennäismailla, ja milloin sitä on turvemaalla viljelty, keskimääräiset sadot jäävät, todennäköisesti lähinnä mikroilmastollisista syistä ehkä n. 1/3 pienemmiksi kuin kivennäismailla. Peruna viljellään myös säännöllisesti kivennäismailla ja se antaa maan keskisatoon verrattuna melko korkeita satoja. Suotuisissa oloissa - jotka ehkä kuitenkin pohjoisessa ovat harvinaisia - peruna saattaa antaa hyviä satoja turvemaillakin.

Tutkimusalueemme pelloista on, kuten mainittu, n. puolet kivennäismailla, toinen puoli turvemailla, ja mikäli peltoalan laajentaminen tulee kysymykseen, n. 2/3 laajennuksista, jos pysytään viljelykelpoiseksi arvostellulla alueella, tulisi turvemaille.

Uudisviljelyyn otetut kivennäismaat antavat kohtalaisia satoja ilman lannoitustakin, mutta etenkin alempiin boniteettiluokkiin kuuluvilta turvemailta ei ilman täyslannoitusta saada juuri mitään satoa. Täyslannoituksella, jossa typpimäärä on ollut n. $46 \mathrm{~kg}$, on Pohjois-Suomessa $66^{\circ}-69^{\circ}$ leveysasteilla suoritetuissa lannoituskokeissa juuri viljelykseen otetulla maalla saatu timoteiheinästä satoja, jotka $4-7$ vuoden keskiarvoina vaihtelevat $740-5470$ kg:n (286 - 2188 ry:n rajoissa) ha:Ita keskiarvon kaikista näistä kokeista ollessa $3080 \mathrm{~kg}$ eli 1233 ry (Valmari, 1956, p. 18-33). Puustuärven (1959, p. 88-90) mukaan vaihtelevat paikallisissa kenttäkokeissa maan keski- ja pohjoisosissa turvemailta eri vuosina saadut heinäsadot kussakin turvemaan boniteettiluokassa jopa moninkertaisesti, ei vain lannoittamattomilla, vaan myös täyslannoituksen saaneilla ruuduilla. Saman kirjoittajan mukaan (1960, p. 29) ovat pohjoissuomalaisten kokeiden eri boniteettiluokkien keskiarvot vaihdelleet rajoissa $4600-6970 \mathrm{~kg}(1840-2788 \mathrm{ry})$. Heinäsadon keskiarvoksi muodostuu 60 kokeen aineistosta $5740 \mathrm{~kg}$ (2300 ry). Kysymyksessä ovat tässä tapauksessa todennäköisesti PKN-lannoituksen saaneet ruudut (vrt. PUUsTJÄRvi 1960, p. 90). SAlosen ym. julkaisussa (1962, p. 137) esitettyjen lukujen perusteella voidaan esittää seuraava sarja turvemaiden nousevalla typpilannoituksella saatavista heinäsadoista (keskim. koko maa). Näitä lukuja voidaan myös verrata samassa tutkimuksessa esitettyihin keskimääräislukuihin kaikista heinänurmilla suoritetuista kokeista (p. 154-155).

\begin{tabular}{|c|c|}
\hline \multicolumn{2}{|c|}{ Kokeet kalkkisalpietarilla } \\
\hline Lannoitus & Sato - Yield \\
\hline \multicolumn{2}{|l|}{ Fertilization } \\
\hline $\mathrm{PK}+$ & ry/ha \\
\hline $15.5 \mathrm{~N}$ & 1880 \\
\hline 31 & 2130 \\
\hline 46.5 & 2320 \\
\hline 62 & $(2410)$ \\
\hline 124 & $(2830)$ \\
\hline
\end{tabular}

Kokeet oulunsalpietarilla

Trials with ammonium nitrate

Lannoitus

Fertilization

$\mathrm{PK}+$

$25 \mathrm{~N}$

50

100

150

200
Sato - Yield

ry/ha

1940

2110

2370

2420 
Näissä, kuten edellisissäkin kokeissa on selvitetty vain ensimmäisen, heinäksi korjatun sadon määrä, jolloin nousevien typpimäärien kokonaisvaikutus, joka suureksi osaksi ilmenee jälkisatojen kasvussa, ei tule näkyviin. Niissä turvemaan kokeissa, joita Perä-Pohjolan koeasemalla on Isotalon johdolla suoritettu, on säilörehuksi tai laiduntamalla korjatun jälkisadon määrä otettu huomioon. Kun myöhemmin esitettävät nurmiviljelyä koskevat laskelmamme perustuvat näiden kokeiden tuloksiin, on syytä verrata näitä toisaalta edellä mainittuihin muihin tutkimuksiin, toisaalta omilta tutkimustiloiltamme saatuihin satotuloksiin.

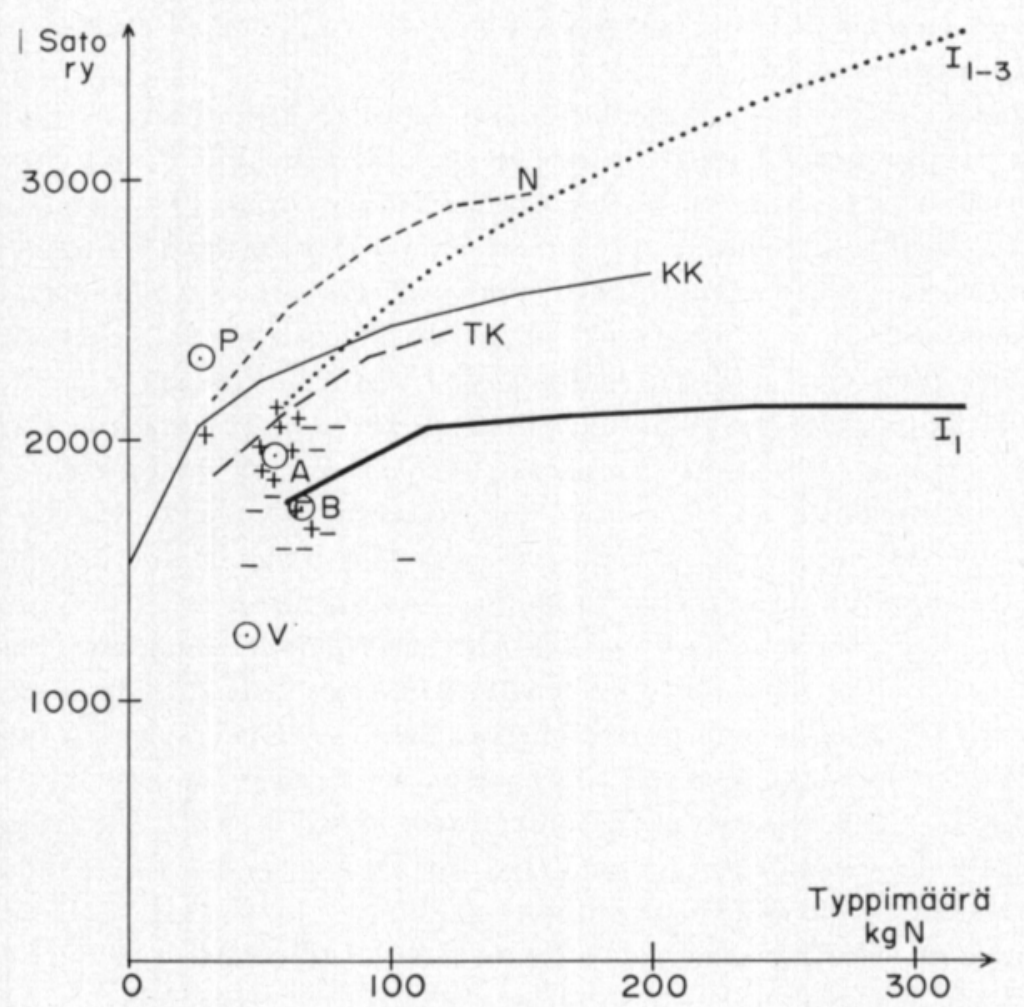

Kuva 3. Typpilannoituksen vaikutus satoon nurmen viljelyssä.

Figure 3. The effect of nitrogen fertilizers on grassland.

$+=$ tutkimustilojen plusvariantit

$-=$ tutkimustilojen minusvariantit

$\mathrm{A}=$ plusvariantit keskimäärin

$\mathbf{B}=$ miinusvariantit keskimäärin

(study farms, individual variants and group averages)
$\mathrm{KK}=$ SALOSEN ym. kaikki kokeet

TK = SALOSEN ym. kokeet turvemailla

$\mathrm{I}_{1}=$ IsotaLon kokeet, nurmen ensimm. sato

$\mathrm{I}_{1-3}=$ IsoTALon kokeet, nurmen kokonaissato

$\mathrm{V}=$ VALMARIn kokeet, heinäsato ennen viljelemättömällä suolla

$\mathrm{P}=$ PUUSTJ ÄRven kokeet turvemailla

$\mathrm{N}$ = Norrbottenin läänin heinänurmilla suoritetut kokeet

(experimental data, national and regional) 
Kuvassa 3 on havainnollisessa muodossa esitetty vertailu tutkimustilojen rehuyksikkösatojen ja edellä selostettujen koetulosten välillä. Vertailussa on kiinnitetty erityistä huomiota eri suurten typpilannoitemäärien ja satojen riippuvuussuhteeseen. Kunkin tutkimustilan keskimääräinen rehuyksikkösato on merkitty + tai - merkillä kohdalle, jossa ry-sato on luettavissa pystysuoralla ja lannoituksessa annettu typpimäärä (N) vaakasuoralla akselilla. + merkityt tarkoittavat niitä tutkimustiloja, joissa ha-sato on yli, - merkityt niitä, joilla se on alle keskisadon. Pisteillä A ja B on merkitty kummankin ryhmän keskisatoja tutkimusjaksolla. Kuviossa kuvaa yhtenäinen viiva "KK" SALOSEN ym. heinänurmilla nousevilla typpimäärillä saatuja satoja kaikissa kokeissa, katkoviiva "TK" vain turvemaiden kokeissa saatuja satoja, $\mathrm{I}_{1}$ kuvaa Isotalon (Perä-Pohjolan koeaseman) kokeissa 1962-64 saatuja heinäsatoja, $\mathrm{I}_{1-3}$ vastaavia kokonaissatoja nurmesta, otettaessa siis huomioon odelmasadot (joista eräissä tapauksissa on korjattu kaksi satoa). Piste V merkitsee keskiarvoa VALmarin $\mathrm{N}_{2} \mathrm{PK}$-lannoituksella ennen viljelemättömällä suolla saaduista heinäsadoista, P PUUstJärven kokoamien turvemaan kokeiden keskiarvoa koko maasta. Vielä on vertailuun otettu mukaan Norrbottenin läänin alueella heinänurmilla suoritettujen typpilannoituskokeiden sadot vuosilta 1957-60 (ERIKSSON 1960), joita kuvaa katkoviiva N.

Verrattaessa tutkimustilojen satoja lannoituskokeiden tuloksiin on tietenkin otettava huomioon koekenttien sadon yleinen paremmuus talousviljelyksiin verrattuna. Tutkimustilojen hehtaarisadot on selvitetty, kuten useimmissa kenttäkokeissa, vain pääsadon osalta. Nämä seikat huomioonottaen tuntuu tutkimustilojen satoja koskevien havaintopisteiden sijoittuminen verraten luonnolliselta, mutta huomio kiintyy samalla niiden suureen hajontaan ja siihen, että yksityisissä tapauksissa on saatu huomattavasti pienempiä satoja kuin mitä typpilannoituksen suuruuden perusteella olisi voitu odottaa.

Oli yllättävää, että viljelmittäisten satotulosten ja lannoitemäärien vuorosuhteet tutkimusalueella osoittautuivat niin heikoiksi kuin ne osoittautuivat. Puutteellisten havaintojen mahdollista vaikutusta tuloksiin tällä kohdalla ei tietenkään voida poissulkea (vrt. LASOLA 1965, p. 106). Mutta edelläesitetyt tiedot Pohjois-Suomen turvemaiden satotulosten suuresta varianssista, joissa maaperälliset ia mikroilmastolliset erot lienevät ratkaisevia, saattanevat selittää senkin merkillisyyden, että tutkimustilojen keskitasoa korkeampia hehtaarisatoja saavuttaneessa ryhmässä käytetyt lannoitemäärät ovat olleet keskimäärin pienempiä kuin keskitasoa alempia hehtaarisatoja saavuttaneessa ryhmässä. Tilaluvun pienuus kummassakin ryhmässä on myös antanut satunnaistekijöille tavallista suuremman merkityksen.

Voinemme kuitenkin taloussuunnitelmissamme lähteä siitä, että väkilannoitteiden käytöllä voidaan aikaansaada s a m a n t i l a n sadoissa lisäyksiä, jotka ovat sopusoinnussa alueella suoritetussa lannoituskoetoiminnassa saatujen tulosten kanssa.

\section{Tekniikka ja ihmistyön käytön rajoitukset}

Pellonviljelyssä edellytetään kaksi tekniikan tasoa: I. hevosen ja tarpeellisten työkoneiden, II. 35-hv. dieseltraktorin ja siihen soveltuvien työkonei- 
den tasoon soveltuva. Sekä katetuotto että työnmenekkiluvut ovat erilaisia näillä tasoilla. Hevostekniikassa hevostunnit on laskettu kussakin tuotannossa jaksoittain ja rajoitukset on asetettu olettaen, että tilalla on yksi hevonen. (Milloin parivaljakolla työskennellään, on oletettu, että naapurit antavat vastavuoroista apua). Rajoituksia ei ole asetettu "muulle kasvukaudellen, koska kiirejaksoja ei esiintyne. Traktorin työkustannukset (ilman korkoja) on laskettu katetuoton vähennyksinä, eikä rajoituksia ole asetettu (koska miestyörajoitus tekee ne tarpeettomiksi). Traktorityötunnit taulukoissa ovat oikeastaan tarpeettomat, eivätkä tule mukaan tietojen käsittelyssä.

Edullisin tuotantosuunta lasketaan silmällä pitäen täystyöllisyyttä avioparille, jonka mies tekee kesällä $9 \mathrm{t}$, talvella $7 \mathrm{t}$ työpäiviä, ja nainen suorittaa tavallisesti $4 \mathrm{t}$ ja kesän kiirekausina $6 \mathrm{t}$ päivässä työtä maatalouden hyväksi. Lisäksi on oletettu, että viljelmällä saadaan aputyövoimaa oman perheen jäsenistä esim. $9 \mathrm{t}$ päivässä kesän kolmena kiirekautena. Tämä aputyövoima hinnoitellaan 2:50 mukaan tunnilta.

Maataloustyöt ja eräät metsätyöt ovat tiettyihin kausiin sidottuja ja säistä riippuvaisia. Tutkimusta varten on erotettu seuraavassa asetelmassa mainitut jaksot. Kullekin jaksolle on edellämainitun työvoiman puitteissa asetettu suurimmat mahdolliset työtuntimäärät, jotka myöhemmissä laskelmissa tunnetaan rajoituksina.

\begin{tabular}{|c|c|c|c|c|c|}
\hline \multirow[t]{3}{*}{$\begin{array}{l}\text { Aika } \\
\text { Period }\end{array}$} & \multirow[t]{3}{*}{$\begin{array}{c}\text { Päiviä } \\
\text { Days }\end{array}$} & \multirow{3}{*}{$\begin{array}{c}\text { Sateet- } \\
\text { tomia } \\
\text { Rainless } \\
\text { days }\end{array}$} & \multirow{3}{*}{$\begin{array}{c}\text { Arki- } \\
\text { päiviä } \\
\text { Week } \\
\text { days }\end{array}$} & \multicolumn{2}{|c|}{$\begin{array}{l}\text { Rajoitukset } \\
\text { Limitation }\end{array}$} \\
\hline & & & & Mt & $\mathrm{Nt}$ \\
\hline & & & & $\begin{array}{l}\text { Man } \\
\text { hours }\end{array}$ & $\begin{array}{l}\text { Woma } \\
\text { hours }\end{array}$ \\
\hline 5. -5.6 & 18 & 12 & & 108 & 72 \\
\hline $6 .-5.7$ & 16 & 10 & & 90 & 60 \\
\hline $7 .-29.7$ & 24 & 12 & & 108 & 72 \\
\hline 8. -15.9 & 27 & 14 & & 126 & 84 \\
\hline
\end{tabular}

\begin{tabular}{|c|c|c|c|c|c|}
\hline $\begin{array}{l}\text { Kylvökausi ................ 17.5. - 5. } 6 . \\
\text { Sowing period }\end{array}$ & 18 & 12 & & 108 & 72 \\
\hline $\begin{array}{l}\text { Varh. kesä ............... 20.6. - 5. } 7 . \\
\text { Early summer }\end{array}$ & 16 & 10 & & 90 & 60 \\
\hline $\begin{array}{l}\text { Heinäkausi ............... } 6.7 .-29.7 \text {. } \\
\text { Hay period }\end{array}$ & 24 & 12 & & 108 & 72 \\
\hline $\begin{array}{l}\text { Elokausi ................. 20.8. - 15. } 9 . \\
\text { Harvest period }\end{array}$ & 27 & 14 & & 126 & 84 \\
\hline $\begin{array}{l}\text { Kasvukausi .............. 17.5. }-25.10 . \\
\text { Growing season }\end{array}$ & 161 & & 137 & & \\
\hline $\begin{array}{l}\text { Muu kasvukausi .......... } \\
\text { Rest of grow. season }\end{array}$ & $\left.113^{1}\right)$ & & $\left.89^{1}\right)$ & 801 & 452 \\
\hline $\begin{array}{l}\text { Muu aika .................. } \\
\text { Other time }\end{array}$ & 204 & & $\left.169^{2}\right)$ & 1183 & 816 \\
\hline Yhteensä - Total & & & & 2416 & 1556 \\
\hline
\end{tabular}

Eräitä sadonkorjuutöitä (säilörehun valmistus) voidaan suorittaa sateisinakin päivinä, joten ne sattuessaan sadonkorjuukausiinkin voidaan sijoittaa "muun kasvukauden" piiriin.

"Muun kasvukauden" ja "muun ajan" kohdalta on asetettava lisärajoitus 
miestyön maksimimäärän mukaan, mikä estäisi metsätyön mahdollisen joutumisen naisten työksi. Metsätyö esiintyy tästä syystä rivillä, jossa kaikki kasvukauden ja "muun ajan" luvut on yhdistetty.

Suonkuivaustyöt ovat miesten työtä, jota voidaan ajatella suoritettavaksi vain kasvukauden aikana. Tätä varten olisi varattava oma rivinsä, jossa rajoituksena on miestyön käytettävissä oleva määrä kasvukauden aikana.

Traktoritekniikassa (II) metsässä suoritettu hevostyö oletetaan saatavaksi vuokraamalla ja hinnoitellaan $60 \%$ :iin tariffinmukaisesta hevosmiehen palkasta (s.o. 2:60/t). Vähennykset tehdään katetuottoon, jota laskettaessa vuotuinen hevostuntiluku on kutakin tapausta varten arvioitu lähinnä hakatun ja ajetun puutavaramäärän perusteella.

\section{Työnkäyttöä koskevat arviot}

Ihmistyön, samoinkuin vetoeläin- ja traktorityönkin käytöstä maatalouden eri tuotantoprosesseihin on erittäin vaikeaa saada yleispätevää tietoa. Täydellinen työpäiväkirjanpito on tiloilla harvinainen, ja SIPILÄn (1946) 1930luvulta keräämään aineistoon perustuvan merkittävän tutkimuksen jälkeen ei ole ilmestynyt tällaisiin perustuvia tutkimuksia. Westermarckin ja MeLÉNin (1962) suunnitteluoppaassa esitetyillä tiedoilla eri tuotannonhaarojen työnmenekistä saattaa tietenkin olla tällaista pohjaa. Maatalouden koneellistamisesta ja työn käytön tehostumisesta johtuen on melkoisia eroja eri ajankohdilta ja erilaista tekniikkaa edustavilta tiloilta saaduissa työnmenekkiluvuissa.

Suunnittelussa käyttökelpoinen menettelytapa lienee se, että tuotantoprosessiin kuuluviin työvaiheisiin käytettävä työaika arvioidaan yleisesti hyväksyttyjen työnormien perusteella. Tällaisiksi normeiksi soveltunevat meillä kasvinviljely- ja metsätöiden osalta maatalouskalentereissa useimpina vuosina mainitut luvut (esim. Pellervon kalenteri 1961, p. 203-208). Niissä esitetään keskimääräiset saavutukset eri töissä laskettuina tuntia kohden koko työaikana. Vaihtoehtoisina mainitaan saavutukset edullisissa, keskimääräisissä ja epäedullisissa olosuhteissa, joissa ääriarvot vaihtelevat kahdenkertaisesti, jopa enemmänkin. Tässä tutkimuksessa on eräin poikkeuksin käytetty keskimääräisiä olosuhteita koskevia lukuja. Kuljetus-, lastaus- ja purkutöiden osalta on käytetty ohjeena myös Nordenborgin $(1939$, p. 60-62) ja EKLUND ym:n (1946) esittämiä lukuja, ja eräiden yksityisten töiden kohdalta on käytetty ammattilehdissä olevaa informaatiota (esim. MylLyLä, 1963) ja omia, kokemukseen perustuvia arvioita.

Eräiden kasvinviljelyssä suoritettujen töiden, erityisesti sadonkorjuu-, kuljetus-, ja käsittelytöiden, vaatiman työajan voitaneen katsoa riippuvan hehtaarisadon suuruudesta. Käytettävissä oleva informaatio ei tarjoa mahdollisuuksia tämän riippuvuussuhteen tarkaksi määräämiseksi.

Koska tämä asia on jollain tavoin otettava huomioon tarkasteltaessa eri intensiteettitasolla tapahtuvan tuotannon edullisuutta, on tiettyjen töiden vaatima aika oletettu sadon määrään suoraan verrannolliseksi. Todellisuu- 
dessa vaihtelee riippuvuussuhde eri töissä ja erilaisen tekniikan esiintyessä.

Suunnittelua varten on tarpeen jaoitella kunkin tuotantoprosessin vaatima aika jollain mielekkäällä tavalla valituille aikaperiodeille. Edellä p. 370 esitetty jaoittelu neljään kiirekauteen, joiden ajoittaminen perustuu alueella todettuihin ilmastosuhteisiin (vrt. edellä p. 345) lienee tarkoituksenmukainen kasvinviljelytöiden jakamisen kannalta. Tietyt työt vaativat ehdottomasti sateettomia päiviä, toisia voi tehdä myöskin sateella. "Muuhun kasvukauteen» luetaan 17.5. ja 25. 10. välillä olevat muut kuin kiirekausiin kuuluvat päivät sekä kiirekausien sadepäivät. "Muu aika" käsittää puolestaan vuoden muihin jaksoihin kuuluvat päivät, joista eräissä laskelmissa otetaan huomioon vain arkipäivät, toisissa (lähinnä kotieläintaloutta koskevissa) myöskin sunnuntai- ja juhlapäivät.

Kasvinviljelytöiden jakaminen sadon suuruudesta riippumattomiin ja riippuviin töihin sekä jaoittelu edellämainituille jaksoille on tapahtunut seuraavilla perusteilla.

\section{Nurmenviljely}

Nurmen perustamiseen kuuluvat työt, kyntö, äestys ja kylvö sekä laitumien aitaus on jaettu 5 vuoden, ojitus 10 vuoden kesken. Äestys, heinänsiemenen kylvö ja väkilannoitteiden levittäminen on luettu sadon suuruudesta riippumattomiin töihin ja ajoitettu kylvökaudelle (17.5.-5.6.). Kuivana korjattavan heinän niitto, pöyhintä, haravointi ja jälkiharavointi on luettu sadosta riippumattomiin töihin. Nämä, samoinkuin sadon suuruudesta riippuvat työt: seipäiden ajo pellolle, seipäiden pystytys, seipäille pano, rippeiden ja pudonneiden heinien seipäille nosto, seipäiden kaato, latoon ajo heinähännällä tai rattailla, latoon sijoittaminen, seipäiden poisto pellolta, jälkiharavointi ja rippeiden latoon ajo on ajoitettu hein ä k a delle (6. 7.29. 7.). Perustamiseen kuuluva kyntö ja ojatyöt on ajoitettu m u u 11 e k a s$\mathrm{v} \mathrm{ukaudelle} \mathrm{ja} \mathrm{katsotaan} \mathrm{sadon} \mathrm{suuruudesta} \mathrm{riippumattomiksi} \mathrm{töiksi.}$ Kalenterinormeja on käytetty $5000 \mathrm{~kg}: \mathrm{n}$ suuruisesta kuivaheinäsadosta.

Odelmasadon korjuussa säilörehuksi väkilannoitteiden kylvö, odelman niitto, haravointi ja jälkiharavointi on katsottu hevostekniikassa sadon suuruudesta riippumattomiksi töiksi, rehun kokoaminen ja kuormaaminen, ajo, purkaminen, levitys, liuostyö, rehun peittäminen ja painojen asettaminen sadon suuruudesta riippuviksi. Traktoritekniikassa korjuu niittosilppurilla ja traktorin peräkärryllä, ynnä rehun siirto säilörehutorniin hankotyönä katsotaan sadon suuruudesta riippuviksi. Nämä työt voitaisiin ajoittaa e lo k a ut e en (20.8.-15.9.), mutta koska niitä voidaan suorittaa sadepäivinä, niistä on osa (1/5) sijoitettu mu u u n kasvukauteen.

Vaihtoehdossa, jossa nurmelta korjataan kaksi satoa säilörehuksi, ensimmäisen sadon korjuutyöt, joiden työn tarve on arvioitu samalla tavalla kuin odelman, on ajoitettu varhaiskesään (20.6.-5. 7.).

Laidunsadon osalta on nurmen ylläpitoon kuuluvat työt laskettu samoin perustein kuin heinä- ja säilörehunurmien kohdalta. Sadonkorjuutyöt sensijaan on jätetty laskelmista pois. Sitävastoin on aitausten yllä- 
pitoon kuuluvat työt, jotka luetaan muuhun kasvukauteen, otettu huomioon siten, että hehtaarin laidunalan aitaamisen on katsottu vaativan hevostekniikan oloissa $12 \mathrm{mt}$ ja $1 \mathrm{ht}$; traktoritekniikassa $9.50 \mathrm{mt}$ ja 3.5 tr.t. Aitaamistyöt on jaettu 5 vuoden osalle. Lisäksi on vuotuisiin korjauksiin katsottu tarvittavan $1 \mathrm{mt}$./ha.

\section{Ohran viljely}

Sadon suuruudesta riippumattomiksi töiksi katsotaan hevostekniikassa äestys, väkilannoitteiden levitys, kylvösiemenen peittaus, kylvö, jyrääminen, jotka on ajotettu kylvökauteen, ojanvierustojen niitto viikatteella, niitto itseluovuttavalla leikkuukoneella sekä jälkiharavointi elokauteen, kaikkien mainittujen ynnä mu u h n kas v u kateen ajoitetun kynnön kuuluessa sadon suuruudesta riippumattomiin töihin. Seipäiden ajo pellolle, seipäiden pystytys, seipäillepano, rippeiden ja pudonneiden ohrien seipäille nosto, kuormaan nosto ja kuorman teko sekä ajo puimalaan on ajoitettu e 1 o $\mathrm{k}$ a u t e e $\mathrm{n}$, puinti ja kuivaaminen viljan siirtoineen edelleen $\mathrm{m} \mathrm{u} \mathrm{u} \mathrm{h} \mathrm{u} \mathrm{n}$ k a s v k a u t e n samoin kuin lajittelu. Nämä työt on edellytetty kalenterinormien mukaisiksi jyväsadon ollessa $2000 \mathrm{~kg}$ ja muuten sadon suuruuteen verrannollisiksi.

Traktoritekniikassa liittyy sadon suuruudesta riippumattomiin töihin rikkaruohojen ruiskutus vedenottoineen, joka on luettu tässä m u u h u k a sv u k a t e e n, kun taas e lok a u t e e n kuuluvat puinti (itsekulkevalla 7 ' säkkikoneella), säkkien ajo pellolta, olkien poisto pellolta heinähännällä sekä kuivaaminen viljan siirtoineen on luettu sadon suuruudesta riippuviin töihin, samoin »m u u h u n a i k a a n» ajoitettavaksi soveltuva lajittelu. Olettamus näiden töiden suorasta verrannollisuudesta satoon on tietenkin tässä tapauksessa liian karkea.

\section{Perunan viljely}

Perunan viljelyyn kuuluvista töistä äestys, väkilannoitteiden levitys, perunoiden kuljetus pellolle, perunavakojen avaus ja peittäminen (hevostekniikassa) ja perunan istutus sekä lanaus ajoitetaan k y lvök a u t e e n ja katsotaan, samoinkuin perunavakojen kahdesti suoritettava multauskin, sadon suuruudesta riippumattomiksi töiksi. Tähän ryhmään kuuluvat myös karjanlannoitus, kyntö ja ojatyöt, jotka ajoittuvat $\mathrm{mu} \mathrm{u} \mathrm{h} \mathrm{u} \mathrm{k} \mathrm{as} \mathrm{v} \mathrm{u} \mathrm{k} \mathrm{u-}$ t e e n ja katsotaan, samoinkuin perunavakojen kahdesti suoritettava multauskin, sadon suuruudesta riippumattomiksi töiksi. Tähän ryhmään kuuluvat myös karjanlannoitus, kyntö ja ojatyöt, jotka ajoittuvat $\mathrm{mu} \mathrm{u} \mathrm{h} \mathrm{u} \mathrm{n}$ k a s v u k a u t e e n, sekä perunoiden idättäminen $(10 \mathrm{~m}$. mt/ha), joka kuuluu m u u h u a i a a n». Perunan heittopyöräkoneella suoritettava konenosto, yhtä vähän kuin sitä edeltävä varsien niitto eivät myöskään riipu sadon suuruudesta, kun taas poiminta ja varastoon kuljetus, jotka ajoitetaan e lo k a u tee n, ynnä lajittelu ja varastointi, jotka ainakin osaksi soveltu- 
vat "m u u a a i ka n a" suoritettavaksi, ovat selvästi sadon suuruudesta riippuvia. Työnormeja vastaavaksi sadoksi on otettu $15400 \mathrm{~kg} / \mathrm{ha}$.

Kasvinviljelyn työnmenekkiä koskevat yksityiskohtaiset laskelmat, samoinkuin eräät muut tutkimukseen liittyvät työtaulukot, ovat konekirjoitteena säilytettävänä Helsingin yliopiston maatalouspolitiikan laitoksessa. Laskelmien tulokset vuotuisina työnkäyttölukuina esitetään seuraavassa asetelmassa:

Tekn. I

\begin{tabular}{|c|c|c|c|c|c|c|}
\hline & $\begin{array}{c}\text { Sato, } \\
\text { ry tai 1 } \\
\text { Yield } \\
\text { fu. or }\end{array}$ & & $\begin{array}{l}\text { Ihmistyö- } \\
\text { tunteja/ha } \\
\text { Labour } \\
\text { hrs/ha }\end{array}$ & $\begin{array}{c}\text { Hev.työ- } \\
\text { tunteja/ha } \\
\text { Horse } \\
\text { hrs/ha }\end{array}$ & $\begin{array}{c}\text { Ihmistyö- } \\
\text { tunteja/ha } \\
\text { Labour } \\
\text { hrs/ha }\end{array}$ & $\begin{array}{c}\text { Traktorityö- } \\
\text { tunteja/ha } \\
\text { Tractor } \\
\text { hrs/ha }\end{array}$ \\
\hline $\begin{array}{l}\text { Timoteiheinä }-\mathrm{TiA}_{1} \cdots \cdots \cdot \\
\text { Timothy hay }\end{array}$ & 2115 & ha & 57.8 & 39.6 & 34.7 & 13.5 \\
\hline $\begin{array}{l}\text { ja odelma }-\mathrm{TiA}_{3} \mathrm{~B}_{2} \text {. } \\
\text { with after. math }\end{array}$ & 2938 & , & 81.4 & 56.3 & 46.6 & 20.8 \\
\hline $\begin{array}{l}\text { Timot. säilörehu } \mathrm{TiC}_{2} \ldots \ldots \ldots \\
\text { Timethy silage }\end{array}$ & 1913 & , & 73.8 & 69.2 & 28.8 & 9.4 \\
\hline,$\quad \mathrm{TiD}_{2} \ldots \ldots$ & 2313 & , & 83.7 & 75.6 & 33.0 & 10.5 \\
\hline Laidun - Pasture $\mathrm{D}_{2} \ldots \ldots$ & 2313 & , & 18.5 & 18.9 & 8.0 & 3.4 \\
\hline $\begin{array}{l}\text { Ohra, kivenn.m. } \\
\text { Barley, min. soil }\end{array}$ & $1700 \mathrm{~kg}$ & $\mathrm{~g} / \mathrm{ha}$ & 92.3 & 86.1 & 25.5 & 14.2 \\
\hline $\begin{array}{l}\text { Ohra, turvem. } \\
\text { Barley, peat soil }\end{array}$ & 1200 & , & 86.1 & 84.4 & 22.8 & 13.7 \\
\hline Peruna - Potato ........... & 15400 & , & 364.5 & 159.9 & 287.4 & 74.9 \\
\hline
\end{tabular}

Tir

\begin{tabular}{|c|c|c|c|c|c|c|}
\hline & $\begin{array}{c}\text { Sato, } \\
\text { ry tai 1 } \\
\text { Yield } \\
\text { fu. or }\end{array}$ & & $\begin{array}{l}\text { Ihmistyö- } \\
\text { tunteja/ha } \\
\text { Labour } \\
\text { hrs/ha }\end{array}$ & $\begin{array}{c}\text { Hev.työ- } \\
\text { tunteja/ha } \\
\text { Horse } \\
\text { hrs/ha }\end{array}$ & $\begin{array}{c}\text { Ihmistyö- } \\
\text { tunteja/ha } \\
\text { Labour } \\
\text { hrs/ha }\end{array}$ & $\begin{array}{c}\text { Traktorityö- } \\
\text { tunteja/ha } \\
\text { Tractor } \\
\text { hrs/ha }\end{array}$ \\
\hline $\begin{array}{l}\text { Timoteiheinä }-\mathrm{TiA}_{1} \cdots \cdots \cdot \\
\text { Timothy hay }\end{array}$ & 2115 & ha & 57.8 & 39.6 & 34.7 & 13.5 \\
\hline $\begin{array}{l}\text { ja odelma }-\mathrm{TiA}_{3} \mathrm{~B}_{2} \text {. } \\
\text { with after. math }\end{array}$ & 2938 & , & 81.4 & 56.3 & 46.6 & 20.8 \\
\hline $\begin{array}{l}\text { Timot. säilörehu } \mathrm{TiC}_{2} \ldots \ldots \ldots \\
\text { Timethy silage }\end{array}$ & 1913 & , & 73.8 & 69.2 & 28.8 & 9.4 \\
\hline,$\quad \mathrm{TiD}_{2} \ldots \ldots$ & 2313 & , & 83.7 & 75.6 & 33.0 & 10.5 \\
\hline Laidun - Pasture $\mathrm{D}_{2} \ldots \ldots$ & 2313 & , & 18.5 & 18.9 & 8.0 & 3.4 \\
\hline $\begin{array}{l}\text { Ohra, kivenn.m. } \\
\text { Barley, min. soil }\end{array}$ & $1700 \mathrm{~kg}$ & $\mathrm{~g} / \mathrm{ha}$ & 92.3 & 86.1 & 25.5 & 14.2 \\
\hline $\begin{array}{l}\text { Ohra, turvem. } \\
\text { Barley, peat soil }\end{array}$ & 1200 & , & 86.1 & 84.4 & 22.8 & 13.7 \\
\hline Peruna - Potato ........... & 15400 & , & 364.5 & 159.9 & 287.4 & 74.9 \\
\hline
\end{tabular}

Timot. säilörehu $\mathrm{TiC}_{2} \ldots \ldots .1913$

Timethy silage

\begin{tabular}{|c|c|c|c|c|c|c|}
\hline & $\begin{array}{c}\text { Sato, } \\
\text { ry tai 1 } \\
\text { Yield } \\
\text { fu. or }\end{array}$ & & $\begin{array}{l}\text { Ihmistyö- } \\
\text { tunteja/ha } \\
\text { Labour } \\
\text { hrs/ha }\end{array}$ & $\begin{array}{c}\text { Hev.työ- } \\
\text { tunteja/ha } \\
\text { Horse } \\
\text { hrs/ha }\end{array}$ & $\begin{array}{c}\text { Ihmistyö- } \\
\text { tunteja/ha } \\
\text { Labour } \\
\text { hrs/ha }\end{array}$ & $\begin{array}{c}\text { Traktorityö- } \\
\text { tunteja/ha } \\
\text { Tractor } \\
\text { hrs/ha }\end{array}$ \\
\hline $\begin{array}{l}\text { Timoteiheinä }-\mathrm{TiA}_{1} \cdots \cdots \cdot \\
\text { Timothy hay }\end{array}$ & 2115 & ha & 57.8 & 39.6 & 34.7 & 13.5 \\
\hline $\begin{array}{l}\text { ja odelma }-\mathrm{TiA}_{3} \mathrm{~B}_{2} \text {. } \\
\text { with after. math }\end{array}$ & 2938 & , & 81.4 & 56.3 & 46.6 & 20.8 \\
\hline $\begin{array}{l}\text { Timot. säilörehu } \mathrm{TiC}_{2} \ldots \ldots \ldots \\
\text { Timethy silage }\end{array}$ & 1913 & , & 73.8 & 69.2 & 28.8 & 9.4 \\
\hline,$\quad \mathrm{TiD}_{2} \ldots \ldots$ & 2313 & , & 83.7 & 75.6 & 33.0 & 10.5 \\
\hline Laidun - Pasture $\mathrm{D}_{2} \ldots \ldots$ & 2313 & , & 18.5 & 18.9 & 8.0 & 3.4 \\
\hline $\begin{array}{l}\text { Ohra, kivenn.m. } \\
\text { Barley, min. soil }\end{array}$ & $1700 \mathrm{~kg}$ & $\mathrm{~g} / \mathrm{ha}$ & 92.3 & 86.1 & 25.5 & 14.2 \\
\hline $\begin{array}{l}\text { Ohra, turvem. } \\
\text { Barley, peat soil }\end{array}$ & 1200 & , & 86.1 & 84.4 & 22.8 & 13.7 \\
\hline Peruna - Potato ........... & 15400 & , & 364.5 & 159.9 & 287.4 & 74.9 \\
\hline
\end{tabular}

Barley, peat soil

Peruna - Potato

\section{Nautakarjatalous}

Kotieläintuotantoa koskevissa laskelmissa ei ole mahdollista käyttää työnormien mukaisia työnmenekin arvioita. Kirjanpitoon perustuvia tietoja mm. lypsylehmien ja lihaeläinten työnmenekistä on niukalti ja niissä on suurta vaihtelua. SıPILÄn (1946) esittämät työnmenekkiluvut ovat ilmeisesti vanhentuneita; ne ovat esim. kansainväliseen tasoon verrattuna varsin korkeita. Karjojen suuruus sekä hoitojärjestelmä, johon liittyvät kotieläinrakennusten ja mekanisoinnin tarjoamat mahdollisuudet vaikuttavat ratkaisevalla tavalla lypsylehmän vaatimaan hoitotyön määrään. MYLlyLä $(1960$, p. 10) on maininnut tästä valaisevia esimerkkejä. Hänen esittämistään luvuista voi laskea, että 16-18 lehmän karjoissa käytetään perinteellisissä parsinavetoissa n. 240 t. lehmää ja vuotta kohden, kun taas pihattonavetoissa selviydytään n. 140 tunnin työllä. Hän toteaa myös parsinavetoiden kohdalla tapahtuneen alenemista työnkäytössä (esim. 1949 ja 1957 välillä n. 60 t.). WESTERMARCK ja MELÉN (1962, p. 51) arvioivat työnkäytön käsinlypsyä soveltavissa 5-10 lehmän karjoissa 220 työtunniksi vuodessa, konelypsyä soveltavissa 200 tunniksi, kun taas $10-20$ lehmän karjoissa vastaavat luvut ovat 200 ja 170.

Lypsykarjatalouden työnmenekin täytyy katsoa olevan riippuvainen myöskin lehmien keskimääräisestä maidontuotoksesta. Käsinlypsyssä lasketaan tavallisesti minuutti maitokiloa kohden, ja tämän perusteella voi laskea, että esim. $400 \mathrm{~kg}$ :n ero vuosituotoksessa vastaa n. 7 t. Kun muussakin työmäärässä 
saattaa olla samansuuntaista eroa, on tässä tutkimuksessa sovellettu 10 tunnin eroa tämän suuruista keskituotoksen eroa kohden.

Tanskalaisten normien mukaan (Håndbog for Driftsplanlaegning 1966) työnmenekki n. 8-12 lehmän karjoissa on n. 120-150 tuntia vuodessa. Niiden mukaan on karjan suuruudesta riippumatta laskettava 760 tuntia kotieläintalouteen, jos sitä harjoitetaan, kun taas kutakin lypsylehmää kohden on lisäksi laskettava 62 t. Näillä edellytyksillä on työnmenekki eläintä kohden jyrkästi aleneva lehmien luvun lisääntyessä. Käytännössä tähän tuskin päästään, ellei navetoiden sisustusta täysin muuteta.

LP-menetelmällä tehdyissä tuotantosuunnitelmissa on yleensä käytetty karjan suuruudesta riippumattomia vakiolukuja työnmenekin osalta. Tämänkin tutkimuksen ensimmäisessä aggregoidussa tuotantosuunnitelmassa on tehty näin. Työnmenekki arvioitiin kolmella esiintyvällä tuotannon tasolla 230, 240 ja 250 työtunniksi lehmää kohden.

Toisessa, disaggregoidussa tuotantosuunnitelmassa, jossa on sovellettu ennen mainittua ZAPFin (1965, p. 60 ja seur.) laskentamallia, on työnmenekin lehmää kohden eräissä tapauksissa edellytetty degressiivisesti pienenevän siirryttäessä suurempiin lehmälukuihin. Työnmenekkiluvut, jotka on esitetty kasvinviljelytöissä sovelletuille kiirekausille jaettuina, nähdään seuraavasta asetelmasta. Lypsykarjatalouden työaika päivää ja eläintä kohden on laidunkautena arvioitu vain puoleksi siitä, mitä se on sisäruokintakautena.

Ihmistyötunteja $3600 \mathrm{~kg}: \mathrm{n}$ maidontuotantoa vastaavassa ryhmässä ${ }^{1}$ ) Hours of labour in the group where milk production is $3600 \mathrm{kgm}$ per cow.

\begin{tabular}{|c|c|c|c|c|c|c|c|c|c|c|}
\hline $\begin{array}{l}\text { Lehm. luku } \\
\text { No. of cows }\end{array}$ & 3 & 4 & 5 & 6 & 7 & 8 & 9 & 10 & $\begin{array}{l}\text { Kesk. } \\
\text { Aver. }\end{array}$ & $\begin{array}{l}\text { Vähennnys } \\
400 \text { kg:n } \\
\text { tuot. kohden } \\
\text { Reduction } \\
\text { per } 400 \mathrm{~kg}\end{array}$ \\
\hline $\begin{array}{l}\text { Kylvök. ................................ } \\
\text { Sowing per. }\end{array}$ & 9.8 & 8.3 & 7.3 & 6.6 & 5.9 & 5.5 & 5.3 & 5.1 & 6.5 & 0.3 \\
\hline $\begin{array}{l}\text { Varh. kesä } \\
\text { Early summer }\end{array}$ & 8.0 & 6.8 & 6.0 & 5.4 & 4.8 & 4.5 & 4.3 & 4.1 & 5.3 & 0.2 \\
\hline $\begin{array}{l}\text { Heinäaika } \\
\text { Hay period }\end{array}$ & 9.8 & 8.3 & 7.3 & 6.6 & 5.9 & 5.5 & 5.3 & 5.1 & 6.5 & 0.3 \\
\hline $\begin{array}{l}\text { Elonkorj. } \\
\text { Harvest per. }\end{array}$ & 11.3 & 9.6 & 8.5 & 7.6 & 6.8 & 6.4 & 6.2 & 5.9 & 7.5 & 0.4 \\
\hline $\begin{array}{l}\text { Muu kasvuk. .............. } \\
\text { Rest of growing per. }\end{array}$ & 104.3 & 89.1 & 71.8 & 67.6 & 63.5 & 58.9 & 56.6 & 54.3 & 69.5 & 3.0 \\
\hline $\begin{array}{l}\text { Muu aika } . . . . . . . . . . . . . . . . \\
\text { Other time }\end{array}$ & 202.1 & 172.8 & 152.3 & 137.6 & 123.0 & 114.2 & 109.7 & 105.3 & 3134.7 & 5.8 \\
\hline Yht. - Total .............. & 345 & 295 & 260 & 235 & 210 & 195 & 187 & 180 & 230 & 10 \\
\hline
\end{tabular}

Lypsylehmän uusimista ja naudanlihantuotannon vaihtoehtoisia tuotantoprosesseja koskevissa laskelmissa tarvitaan vasikoiden ja nuorten nautaeläinten hoitotyötä koskevia aikanormeja. Tämän tutkimuksen ensimmäisessä vaiheessa vasikan kasvatuksen työnmenekki arvioitiin seuraavasti: 


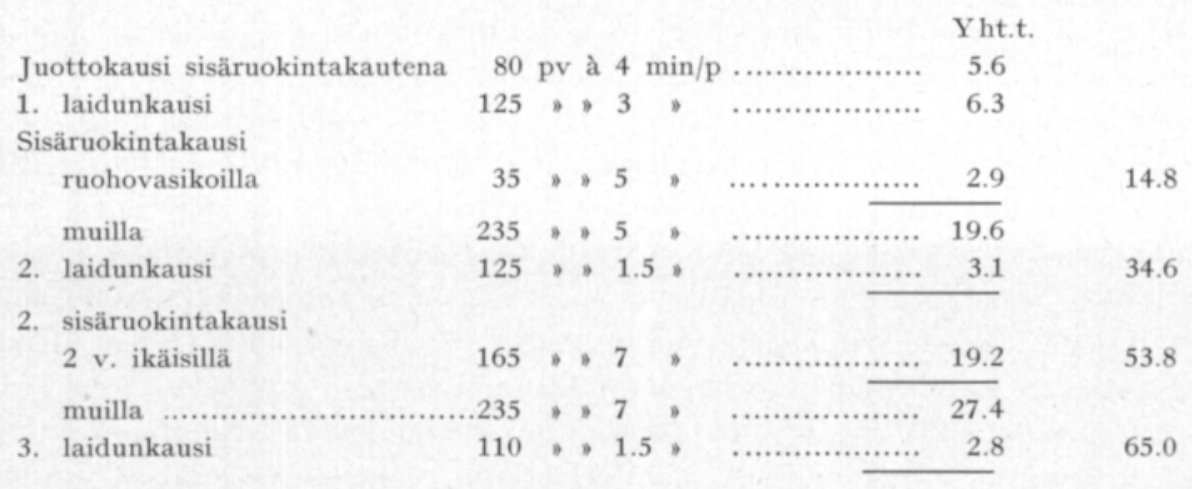

Näitä arviolukuja, jotka tutkimusalueen olosuhteissa myöhemmin muodostamamme käsityksen mukaan ovat liian alhaisia, käytettiin ensimmäisessä aggregoidussa suunnitelmassa. Myöhemmin on sovellettu Westermarckin ja MElÉvin (1962, p. 55) esittämiä lukuja. Niiden mukaan tarvitaan vasikan kasvattamiseen 6 kuukauden ikään 40 työtuntia, yhden vuoden ikään 60 tuntia sekä keskimääräiseen poikimisikään $(26 \mathrm{kk})$ kaikkiaan 130 tuntia. Vasikoiden hoitotyö on laidunkautena vähemmän aikaa vaativa kuin sisäruokintakautena. Toisena laidunkautena se on päivittäin vähemmän kuin neljännes sisäruokintakauden työnmenekistä.

\section{Muи kotieläintalous}

Lihotussian kasvatuksen työnmenekki on, tässäkin seuraten WESTERMARCKin ja MELÉNin esitystä (p. 58), arvioitu 6-7 viikon iästä lähtien 2 työtunniksi kuukautta kohden, mikä soveltuu olosuhteisiin, joissa kasvatetaan vain muutamia harvoja lihotussikoja vuodessa. Noin $80 \mathrm{~kg}: \mathrm{n}$ teuraspainoon kasvatettavan sian hoitoon kuluu siten 12 työtuntia ja $100 \mathrm{~kg}: \mathrm{n}$ painoisen vastaavasti 15 tuntia. Aggregoidussa suunnitelmassa sovellettiin 12 tunnin työnmenekkiä.

Lampaan kasvatuksen työnmenekki arvioitiin ensimmäisessä laskelmassa 5 työtunniksi uuhta kohden. RYynänEN (1969, p. 111) on tutkimuksessa 46 uuhen katraasta päätynyt 8 tunnin työnmenekkiin, mitä myös WESTERMARCK ja Melén (1962, p.64) pitävät laskelmiin sopivana. Westermarckin ja Mattilan monisteessa v:Ita 1969 on n. 16 uuhen katraassa todettu 14 tunnin työnmenekki. Koska unhet etenkin karitsoimisaikana vaativat melkoisesti huolenpitoa, uusimmassa disaggregoidussa laskelmasa on sovellettu jonkinverran RYYNÄSEN toteamaa suurempaa työnmenekkiä (10 t). Työnmenekki on laidunkautena noin puolet sisäruokintakauden päivittäisestä työnmenekistä.

\section{Karjanlannan kuljetus ja levitys}

Karjanlannan kuljetus ja levitys on katsottu karjatalouteen kuuluvaksi työksi. Se sijoittuu traktoritekniikassa muuhun kasvukauteen, hevostekniikassa suurimmalta osalta muuhun aikaan. Lypsylehmien osalta arvioidaan 
lannan tuotokseksi $6 \mathrm{t}$ ja työtä käytetyksi edellisessä tapauksessa $3.5 \mathrm{mt}$ ja 3.5 tr.t eläintä kohti, jälkimmäisessä muuna kasvukautena vastaavasti 0.9 $\mathrm{mt}$ ja $0.6 \mathrm{ht}$, muuna aikana $6 \mathrm{mt}$ ja 6 ht. Naudanlihantuotannossa käytetään kasvatuskauden pituudesta riippuen kertoimia $0.20,0.75,0.60$, tapauksissa B, C, ja D, sianlihan tuotannossa 0.15 ja lampaan kasvatuksen kohdalta (uuhta kohden) kerrointa 0.10 , eläinyksikköä kohti tarvittavan työn johtamiseksi ylläesitetyistä luvuista.

\section{Metsätalous}

Metsätalouden töistä on tässä tutkimuksessa käsitelty hakkuu- ja ajotöitä, joita viljelijöiden katsotaan suorittavan omalla työvoimallansa, tai milloin hakkuita keskitetään harvemmille tiloille, joihin viljelijät osallistuvat palkkaa saavina työntekijöinä.

Hakkuu- ja ajokustannukset on tässä tutkimuksessa arvioitu soveltaen niitä urakkapalkkanormeja, jotka on vahvistettu 31.10.1960 tehdyssä työehtosopimuksessa Metsähallituksen, Maataloustyönantajain Liiton, Valtionrautateiden Polttoainetoimiston ja Suomen Maaseututyöväen Liiton kesken (Metsätyöpalkkojen taulukot, palkkausalue 2, 1960). Työmenekkiluvut erilaisissa töissä on johdettu näistä palkkanormeista tavalla, jota käsittelemme yksityiskohtaisemmin metsätaloutta koskevien laskelmien yhteydessä. 


\section{Maatalous uudistilan taloussuunnitelmassa}

\section{Hevos- ja traktorityön kustannukset}

Hevostyön kustannuksia arvioitaessa on perustana pidetty lähinnä maatalouden kannattavuustutkimuksen erikoisselvityksiä 76 tilalta (TSMK 196162, p. 32). Tästä tutkimuksesta käy ilmi, että kaluston, kuivikkeiden sekä kengitys- ja eläinlääkintäpalvelujen aiheuttamat kustannukset olivat mainittuna tilivuonna yht. 98:50 ja eläinpääoman korko 23:75, eli nämä erät yhteensä 127:45 työhevosta kohden. Hevosten poistokustannukset puolestaan on peitetty hevosmyyntituloilla. 127: - mk pidetään tämän tutkimuksen hevostyön maksettavina muuttuvina kustannuksina useimmissa laskelmissa.

Hevosten ruokintaan on erikoisselvityksen alaisilla kirjanpitotiloilla käytetty 341 ry kauroja ym. väkirehua, 1258 ry heiniä, 722 ry laidunta ja 24 ry muuta rehua. Väkirehun arvo on 29.1 p kilohinnan mukaan ollut 99:23 hevosta kohden. Hevostunteja on tiloilla ol.ut keskim. 663, ja hevostunnin keskimääräinen kustannus 1:38.2 työtuntia kohti.

Ihmistyötä hoitotyöhön on arvioitu käytetyksi 136 t. Tämä on jaoiteltu eri kausille siten, että laidunkautena on päivittäin käytetty noin puolet siitä, mitä sisäruokintakautena. Ihmistyö samoinkuin rehutkin on sisällytetty ilman hinnoittelua LP-taulukoihin.

Nurmenviljelyn mahdollisia vaihtoehtoja koskevassa esilaskelmassa on ihmistyölle laskettu edeltä päin arvioitu hinta, 2:- työtuntia kohden. Hevostyön muuttuva kustannus on tässä arvioitu siten, että hevosen katsotaan työssä ollessaan kuluttavan päivässä keskimäärin 3.2 ry enemmän kuin joutilaana ollessaan. Tämä rehu on hinnoiteltu kauran hintaan $(36 \mathrm{p} / \mathrm{kg})$. Hevosen hoitotyön on vielä katsottu erilaisista syistä lisääntyvän noin puolella tunnilla hevosen työssäolopäivää kohden. Laskettaessa yllämainitun työpalkan mukaan ja työpäivä 8-tuntiseksi saadaan hevostyön muuttuvaksi kustannukseksi 25 p työtuntia kohden.

Traktorin peruskustannukset koostuvat $6 \%$ :n korosta puolella 10000 mk uudisarvosta $10 \%$ poistosta, sekä vakuutus- ja säilytyskustannuksesta, ollen yhteensä $1350 \mathrm{mk} / \mathrm{v}$. Traktorityön muuttuvaan kustannukseen on tässä sisällytetty kunnossapito- ja korjauskustannukset (540:- vuodessa, $90 \mathrm{p}$ tuntia kohden), polttoainekustannus $(75 \mathrm{p} / \mathrm{t})$ sekä voiteluainekustannukset $(20 \mathrm{p} / \mathrm{t})$. Yhteensä on muuttuva kustannus siten 1:85 käyttötuntia kohden. Traktorityön yksinomaan rahana suoritetut kustannukset vähennetään kunkin tuotantoprosessin kohdalta katetuotosta. 


\section{Erinäisten laitteiden ja koneiden kustannuksista}

Nurmenviljelyyn perustuvaa tuotantoa voi nykyisin tuskin ajatella ilman säilörehunvalmistusta tai muuta menetelmää, jolla nuoren ruohon aineosat saadaan arvoansa menettämättä talviruokintaan. Tässä tutkimuksessa tehdyt laskelmat perustuvat yksinomaan AIV-menetelmällä valmistetun säilörehun käyttöön. Useimmat tutkimusalueen tilat joutuisivat rakentamaan AIV-rehusäilöjä tai torneja, joiden ylläpitokustannukset siten on otettava huomioon muttuvina kustannuksina.

Säilörehutornien perustamis- ja vuotuiskustannuksia koskevat laskelmat nojautuvat Westerbergin ja Leväsen (1964) betonitorneja ja MAUnun (1966) lautatorneja koskeviin kustannuslaskelmiin. Noin $100 \mathrm{~m}^{3}$ vetoisen betonitornin perustamiskustannus on näissä annetuilla edellytyksillä arvioitu 2000 3000 markaksi, riippuen siitä sijoitetaanko se katettuun tilaan vai ulkopuolelle. Saman suuruisen puisen tornin tarvikekustannukset olisivat jälkimmäisen kirjoittajan mukaan nousseet n. 1600 markkaan. Laskelmiemme mukaan kustannukset - joihin olisi lisättävä puuraaka-aineen hinta - nousisivat tarvikkeiden osalta korkeammiksi, n. 2300 mk:aan ja työkustannuksineen n. 2600 mk:aan. Betonitornin rakennuskustannuksista on poisto arvioitu $2 \%: \mathrm{ksi}$, puutornin $3 \%: \mathrm{ksi}$, ja $6 \%$ koron huomioonottaen vuotuiskustannukset nousisivat betonitornien osalta 236 tai $163 \mathrm{mk}$ :aan riippuen siitä, onko torni sijoitettu ulos vai sisälle; puutornin kohdalta vastaavasti 231 tai $185 \mathrm{mk}$ :aan. Vuotuiskustannukset säilytettävää rehuyksikköä kohden olisivat samassa järjestyksessä 2.4, $1.6,2.3$ ja 1.9 p.

Säilörehunvalmistuksessa Tekn. II:n puitteissa käytettävän niittosilppurin hankintahinta 1966 voitiin laskea 2200 markaksi. Kymmenvuotisen poiston edellytyksellä ja arvioiden kunnossapitokustannukset 150 markaksi päädytään $6 \%$ :n korkoineen peruskustannuksen osalta $436 \mathrm{mk}$ :n vuotuiskustannukseen. Korjattavan määrän vaihdellessa $250-750$ tonnin välillä nämä kustannukset vaihtelisivat $0.17-0.06$ pennin välillä kiloa kohden, keskim. $0.09 \mathrm{p} / \mathrm{kg}$. Käyttökustannukset tunnissa voitaisiin laskea 4 markaksi, jos traktorityöstä huomioidaan vain muuttuvat kustannukset. Jos korjuumäärä on 2.5 to/t käyttökustannukset ovat $0.16 \mathrm{p} / \mathrm{kg}, 5$ tonnin korjuumäärällä $0.08 \mathrm{p} / \mathrm{kg}$. Ry kohden nämä kustannukset olisivat peruskustannusten osalta $1.4-0.5$ penniä, kesk. 0.7 $\mathrm{p} / \mathrm{kg}$ sekä käyttökustannusten osalta $1.4-0.7 \mathrm{p} / \mathrm{kg}$. Nämä kustannukset olisivat mahdollisia, jos 3-7 tilan välillä olisi tehokasta yhteistyötä.

Kotieläintuotantoa harjoittavat tilat eivät vaikeuksitta tule toimeen ilman konevoimaista kotitarvemyllyä. Erään nostolaitesovitteisen myllyn hinta oli v. 1966 1180:-, minkä summan korko ja poisto on tässä arvioitu 153:40 mk:ksi vuodessa. Kun kunnossapidon on oletettu vaativan 20 :- vuodessa, nousevat peruskustannukset $30000 \mathrm{~kg}: \mathrm{n}$ vuotuisen jauhatusmäärän mukaan 0.6 penniin, $50000 \mathrm{~kg}: \mathrm{n}$ mukaan 0.35 penniin kilolta. Käyttökustannus koostuu traktorityön ja miestyön hinnasta, jotka voitaneen tässä arvioida 5 tai 6 markaksi. Työsaavutuksen ollessa $500 \mathrm{~kg} / \mathrm{t}$, käyttökustannus olisi $1.0-1.2 \mathrm{p} / \mathrm{kg}$ ja kokonaiskustannus $1.4-1.8 \mathrm{p} / \mathrm{kg}$ ja $100 \mathrm{~kg}$ :n tuntisaavutuksin $0.3 \mathrm{p}$ vähemmän. Kun otetaan huomioon myös siirto- ja valmistelukustannukset, lienee perustel- 
tua arvioida rehuviljan jauhatus- tai rouhimiskustannukset $1.5-2$ penniksi kilolta.

Tutkimuksen ajankohtana oli alueella käytössä eräiden tilojen yhteinen leikkuupuimuri. Sen käyttökustannus on arvioitu tuolloin vallinneen yleisen vuokratariffin mukaan, joka kalentereissa oli ilmoitettu 38 markaksi käyttötuntia kohden.

\section{Uudisraivauskustannukset}

Investoinnit uudisraivauksiin ovat tutkimusalueella olleet yleisiä ja suosittuja, koska niihin on voitu käyttää omaa työvoimaa valtion maksaessa ainakin osittaista työpalkkaa uudisraivauspalkkioiden muodossa. Tässä tutkimuksessa uudisraivauskustannukset on arvioitu palkkioita vähentämättä päätutkimuksessa esitetyn numeroaineiston pohjalla v. 1961 hintatason mukaisesti (Finnish Study Group 1969, p. 109). Kivennäismaiden kohdalta on hehtaarin raivauskustannus arvioitu 1400 markaksi, turvemaiden kohdalta 800 markaksi. Muuttuva vuotuiskustannus on laskettu $3 \%$ mukaan.

\section{Sovelletut hinnat ja pääomarajoitukset}

Maa- ja metsätaloustuotteiden reaalisten tukku- ja vientihintojen kehityssuunnista antavat käsityksen liitteissä 1 ja 2 esitetyt kuviot.

Tutkimuksessa on yleensä sovellettu niitä hintoja, joita viljelijät ovat tutkimusalueella jaksolla 1959-63 saaneet tuotteistansa ja maksaneet tarvikkeistansa. Kuitenkin on ensi käden tietoja saatu ainoastaan maidon hinnoista, joihin on sovellettu Kajaanin osuusmeijerin tutkimustiloille maksamia hintoja. Maidon hintoihin sisältyi alueella, kuten yleensä Pohjois-Suomessa, valtion erityistukea, niin että hinta tutkimusalueella oli $36.4 \mathrm{p} / \mathrm{kg}$. Maan keskihinta Pellervo-Seuran Markkinatutkimuslaitoksen tilaston mukaan oli $33.5 \mathrm{p}$.

Muiden maataloustuotteiden ja tarvikkeiden hintoina on käytetty PSM:n tilaston maan keskihintoja. Metsätaloustuotteiden hintoja on käsitelty yksityiskohtaisemmin alempana.

Kun maidon ja muiden tuotteiden hintasuhteilla on laskelmien tulosten kannalta hyvin ratkaiseva merkitys, on eräitä vaihtoehtoisia laskelmia tehty soveltaen sellaista hypoteettista mahdollisuutta, että maatalouden olisi esim. poolijärjestelyin ilman valtion vientitukea ylläpidettävä tuottajahintatasoa. Mainittujen vuosien vientimäärien ja vientihintojen perusteella on arvioitu, että kuluttajahintojen ennallaan pysyessä maidon hintaa olisi tuolloin jouduttu laskemaan n. 25 p:iin kilolta.

Kun tutkimuskaudesta on kulunut pitkä aika, on eräitä vaihtoehtoisia laskelmia tehty myöskin vuoden 1972 hintatason mukaan. Muutoksia ei kuitenkaan ole tehty kaikissa pääomien poisto- ja kunnossapitokustannuksissa.

Eräisiin viimeksi laadittuihin ohjelmiin on otettu myös pääomarajoitus. Pääomarajoitus on koskenut ainoastaan maa- ja rakennuspääoman yli tarvittavan pääoman määrää. Sitä asetettaessa on koetettu käyttää vertailuperustana 
teollisuustyöpaikan perustamisen vaatimaa pääoman tarvetta. Ins. Risto EKLUNDilta saadun informaation perusteella on asetettu kaksi vaihtoehtoista rajoitusta, ahtaampi 200000 ja väljempi $400000 \mathrm{mk}$.

\section{Nurmenviljelyn ja lypsykarjan ruokinnan suunnittelu}

\section{Yleistä}

Tutkittavana olevan alueen maataloustuotannossa peltonurmien hyväksikäyttöön perustuva maidontuotanto on viime aikoina muodostanut rungon, jonka varaan maatilatalous säännöllisesti rakentuu. On selvää, että nurmenviljelyä ei yleisesti katsoen voida pitää itsenäisenä tuotantomuotona, jonka tuotteet olisivat sellaisinaan markkinoitavissa. Toisaalta ovat maidon markkinointimahdollisuudet alueella yleensä turvattuja, edellyttäen että asutusalueilla säilyy kohtuullinen määrä maidontuottajia, ja maito muodostaa myös tärkeän osan viljelijäperheiden omasta elintarvikkeiden kulutuksesta. Maidontuotantoon liittyy oleellisesti naudanlihan tuotantoa, jota voidaan hintasuhteiden salliessa melkoisestikin laajentaa lisäämällä ruohovasikoiden kasvatusta. Tällainen tuotanto soveltuu erityisesti voimeijerialueille, joilla on mahdollisuus vasikoiden kasvatuksessa käyttää tiloille palautettavaa kuorittua maitoa. Toisaalta voidaan tämän sivutuotteen samoinkuin juustonvalmistuksessa saatavan heran nojaan perustaa myöskin lihotussikojen kasvatusta. Lammastalouskin voi hyötyä näistä sivutuotteista, joskin sen harjoittaminen on mahdollista maidontuotannosta riippumatta.

Kun maidontuotannolla näin ollen yleensä on keskeinen asema varsinaisessa maataloudessa, on syytä erityisesti syventyä niihin vaihtoehtoisiin tuotantoprosesseihin, joiden voisi odottaa olevan käytettävissä edullisimman yhdistelyn muodostamiseksi. Näihin kuuluvista tuotantoprosesseista ovat itse nurmen viljelyyn ja sen sadon korjuuseen ja säilytykseen liittyvät erityisen tärkeitä. Kuten jo PoIJÄRven tutkimukset 1920-luvulla osoittivat, pelkästään kuivana korjattavan heinäsadon määrä ja laatu, joka viimeksimainittu ruokinnan suunnittelussa on varsin tärkeä, riippuvat suuresti niiton ajankohdasta. Tällä on myös vaikutusta odelmasadon suuruuteen, ja edelleen vaikuttaa kokonaissadon sekä suuruuteen että laatuun sadon säilytystapa, joka on tullut taloudellisesti yhä merkityksellisemmäksi sen jälkeen kuin uusia menetelmiä erityisesti säilörehun valmistuksessa on tullut käytäntöön.

Useissa tutkimuksissa on todettu myös nurmien lannoituksen vaikutus nurmien sadon määrään ja laatuun. Niinpä etenkin nousevien typpimäärien on havaittu lisäävän sekä satoa että sadon suhteellista raakavalkuaismäärää. Sitävastoin näyttää siltä, että typpilannoituksen lisäys ei paljonkaan vaikuta raakakuidun määrään (vrt. TURKKI 1970, p. 55). Raakakuituprosentti näyttää sitävastoin paljon riippuvan korjuuajasta, jonka siirtyminen myöhäisemmäksi ajankohdaksi lisää kasvikuidun pitoisuutta ruohossa. Korjuuaikojen järjestelyllä lienee siten vaikutusta myöskin ruokintasuunnitelman kannalta merkityksellisiin täyttävyyslukuihin.

Tutkimusalueen nurmenviljely tapahtuu erityisen suuressa määrässä turve- 
mailla, joilla myöskin sen laajentamisedellytykset ovat parhaat. PoIJÄRvI on eräässä tutkimuksessa (1927) selvitellyt suomailla kasvaneiden heinien tuotantoarvoa suhteessa kovalla maalla kasvaneisiin. Tässä tutkimuksessa, jonka aineisto on osaksi Pohjois-Savosta ja Kainuusta, todettiin (esim. p. 56) että suomaan heinä saattaa olla täysin kovanmaan heinän veroista, mutta eräissä tapauksissa se on sulavuutensa ja tuotantoarvonsa puolesta voinut olla jopa $8 \%$ huonompaa. Tällaisissa tapauksissa sen kasvisyypitoisuus on ollut suurempi ja kivennäiskokoomus epäedullisempi kuin kovan maan heinässä. Hyvä viljelytapa, lannoitus ja ojitus on vaikuttanut laatua kohottavasti, ja kivennäisravinnon, mm. keittosuolan lisääminen ruokinnassa on korjannut mahdollisia laatuheikkouksia.

Tässä tutkimuksessa on maidon tuotantoprosessit koetettu valita siten, että ne yhdistettyinä nurmiviljelyn lannoitemääristä ja korjuutavoista riippuviin vaihtoehtoisiin tuotantoprosesseihin antavat edullisimman tuloksen. Maidon tuotantoprosessien valinnassa on tosiasioina otettava huomioon lehmien perinnölliset ominaisuudet, jotka asettavat ylärajan taloudelliselle maidontuotannolle, ja saattavat myös vaikuttaa maidontuotantokäyrän muotoon. Näiden määrittämiseen ei ole muita perusteita kuin aikaisempina vuosina saavutetut keskituotannot, jotka sopivat kuvaamaan tuotantokapasiteettia, jos voimme olettaa, että eläimet on ruokittu normien mukaan. Kun alueella esiintyy eritasoisia karjoja, saattaa olla paikallaan ottaa laskelmiin erilaisia vaihtoehtoisia tuotostasoja.

\section{Laskelmien perustana olevat lannoituskokeet}

Tuotannon järjestelyä koskevissa laskelmissa on siis päätuotteen, heinän, sadon määrän ja laadun riippuvuus lannoituksesta katsottu tarpeelliseksi ottaa huomioon. Perä-Pohjolan koeasemalla Rovaniemellä suoritetut lannoituskokeet sopivat tässä suhteessa lähtökohdaksi. Niissä on käytetty varsin huomattavasti porrastettuja typpimääriä ja sekä kuiva-aineen että raakavalkuaisen määrät on selvitetty eri koejäsenistä.

Suomussalmella on heinänviljely miltei yksinomaan timoteiheinän viljelyä. Pyrittäessä korkeampaan satoon lähinnä typpilannoitteita käyttäen on nurmien siemensekoituksissa syytä käyttää myös koiranheinää tai nurminataa. Vuosina 1962 - 64 suoritetuissa kokeissa on timotein ja nurminadan sekoituksella saadut heinäsadot olleet lannoituskokeissa vertailtavina.

Tässä yhteydessä todettakoon, että leveyspiirien melkoisesta erosta huolimatta sääolot ovat Suomussalmella monessa suhteessa samanlaiset kuin PeräPohjolan koeaseman sijaintipaikalla Rovaniemellä. Tähän tulokseen voi päästä tarkastelemalla esim. keskilämpöä kuvaavien isotermien kulkua erityisesti keväällä ja kesällä vv. 1921-50 (Korhonen, 1958 b, p. $344-348$ ). Vuoden sademäärä on Suomussalmella n. $100 \mathrm{~mm}$ korkeampi kuin Rovaniemellä.

Nousevilla typpimäärillä saadut sadonlisäykset ilmenevät suureksi osaksi jälkisadossa, jonka talteenotossa säilörehunvalmistus, lähinnä AIV-menetelmää käyttäen, on miltei välttämätöntä. Sikäläisillä asutustiloilla on toistaiseksi vain harvoissa tapauksissa säilörehutorneja, joten intensiivisempään tuotantomuotoon siirtyminen edellyttää yleensä sijoituksia näihin. Jokin osa nurmien jälki- 
kasvusta on kuitenkin varattava laiduntamiseen, koska varsinaisten laidunten tuottavuus on kesäkuulta lähtien sännöllisesti aleneva. Voitaneen arvioida, että kolmannes lypsylehmien laiduntarpeesta on normaalisesti tyydytettävä niittonurmien odelmalla.

Tätä tutkimusta varten on MMT Armo IsoTALo Maatalouden Tutkimuskeskuksen suostumuksella antanut käytettäväksi Perä-Pohjolan koeaseman koetuloksia vuosilta 1962, 1963 ja 1964. (Maatalouden Tutkimuskeskus, PeräPohjolan koeaseman koetuloksia. Monisteet 1962, 1963, 1964). Laskelmiemme pohjana on käytetty kahta boniteettiarvoa 5 vastaavalla saraturpeella suoritettua lannoituskoetta, joista ensimmäinen (N:o 8, Eri typpimäärien koe, per. 1962) käsittää kaksi koesarjaa, joista seuraavassa käytetään kirjaimia A ja B. Koekasvina on timotei-nurminata, jonka ensimmäinen sato on korjattu tavalliseen tapaan heinäksi, toinen tässä oletettu valmistetun säilörehuksi. Toinen koe esiintyy nimellä (N:o 10, AIV-nurmen lannoitustapakoe, per. 1962) ja käsittää myös kaksi koesarjaa, joita merkitsemme kirjaimin C ja D. Nurmi koostuu timoteista, nurminadasta ja puna-apilasta. Viimeksimainitun merkitys lienee kuitenkin ollut vähäinen eikä sitä enää esiinny kolmannen vuoden nurmessa. Niittoajat on tässä kokeessa järjestetty silmälläpitäen säilörehuksi valmistamista, ja niitto on kahtena vuonna suoritettu kolmasti kasvukauden aikana.

Eri koejäsenien lannoitus, joka koostuu kasvukauden alussa annetusta peruslannoituksesta (väkevä Oulun Y-lannos, $12-15-18$ ) sekä niiton jälkeisestä pintalannoituksesta (Oulun salpietari, 25) on kasvinravinteiksi muunnettuna ollut koesarjoissa alla olevan asetelman mukainen. Lannoituskustannus vallinneissa hintasuhteissa sisältyy myös asetelmaan.

\begin{tabular}{|c|c|c|c|c|c|c|c|c|c|}
\hline & $\mathrm{N}$ & $\mathrm{P}_{2} \mathrm{O}_{5}$ & $\mathrm{~K}_{2} \mathrm{O}$ & $\begin{array}{c}\text { Lann. kust. } \\
\text { Cost of } \\
\text { fertilizing } \\
\mathrm{mk} / \mathrm{ha}\end{array}$ & & $\mathrm{N}$ & $\mathrm{P}_{2} \mathrm{O}_{5}$ & $\mathrm{~K}_{2} \mathrm{O}$ & $\begin{array}{l}\text { Lann. kust. } \\
\text { Cost of } \\
\text { fertilizing } \\
\mathrm{mk} / \mathrm{ha}\end{array}$ \\
\hline & & & & & $\mathrm{C}_{0}$ & 0 & 0 & 0 & 0 \\
\hline$A_{1} \ldots \ldots \ldots$ & 60 & 75 & 90 & 128 & $\mathrm{C}_{1}$ & 30 & 38 & 45 & 64 \\
\hline$A_{2} \ldots \cdots \cdots$ & 110 & 75 & 90 & 173 & $C_{2}$ & 60 & 75 & 90 & 128 \\
\hline$A_{3} \ldots \ldots \ldots$ & 160 & 75 & 90 & 219 & $\mathrm{C}_{3}$ & 120 & 150 & 180 & 255 \\
\hline$A_{4} \ldots \ldots \ldots$ & 260 & 75 & 90 & 310 & $\mathrm{C}_{4}$ & 240 & 300 & 360 & 510 \\
\hline$B_{1} \ldots \ldots \ldots$ & 120 & 150 & 180 & 255 & $\mathrm{D}_{1}$ & 130 & 38 & 45 & 155 \\
\hline $\mathrm{B}_{2} \ldots \ldots \ldots$ & 170 & 150 & 180 & 301 & $\mathrm{D}_{2}$ & 160 & 75 & 90 & 219 \\
\hline$B_{3} \ldots \ldots \ldots$ & 220 & 150 & 180 & 346 & $\mathrm{D}_{3}$ & 220 & 150 & 180 & 346 \\
\hline$B_{4} \ldots \ldots \ldots$ & 320 & 150 & 180 & 437 & $\mathrm{D}_{4}$ & 340 & 300 & 360 & 601 \\
\hline
\end{tabular}

Koska A ja B-sarjan eräät koejäsenet lannoitusmääriensä puolesta ovat lähellä toisiaan, ja korjuuajat ovat samat, on muutamia näistä yhdistetty tuotantoprosessien luvun vähentämiseksi. Täten on muodostettu yhdistelmät $A_{2} B_{1}$, joissa lannoitus on keskim. $115 \mathrm{~kg} \mathrm{~N}$ ja kustannus $237:-/ \mathrm{ha}, \mathrm{A}_{3} \mathrm{~B}_{2}$, vastaavasti keskim. $165 \mathrm{~N}$ ja 260 : - sekä $A_{4} B_{3}$, jossa luvut ovat $240 \mathrm{~N}$ ja 328:- . Sarjoissa $C$ ja $D$ on vastaavasti yhdistetty $C_{4} D_{3}$, jossa typpimäärä on $230 \mathrm{~kg}$ ja lannoituskustannus 428 :- / ha. 
Koeselostuksista on mahdollista laskea kuiva-ainesato samoinkuin raakavalkuaisenkin määrä eri koejäsenille hehtaaria kohden. Ruohon kuiva-aineen raakakuituprosentti on myöskin analyysillä selvitetty. Kolmivuotisin keskiarvoin esitettyinä nämä luvut on koottu taulukkoon 11. Tähän taulukkoon on edelleen liitetty arviot säilytystappioiden jälkeen käytettävissä olevan rehuyksikkö- ja sulavan raakavalkuaissadon määrästä sekä rehun kuiva-aine- ja rehuyksikkömäärän suhteesta eli rehun täyttävyydestä. Arvioiden perustana ovat seuraavat olettamukset.

Rehun säilytyksessä on oletettu tapahtuvan häviöitä PoIJÄRven (1955, p. 201) julkaisemien tutkimustulosten mukaan, jotka ovat suhteellisesti suotuisista koeolosuhteista. Heinän kuivauksessa häviöt ovat kuiva-aineessa $10 \%$, raakavalkuaisessa $22 \%$ ja rehuyksikkömäärässä $27 \%$. AIV-säilörehun valmistuksessa vastaavat prosentit ovat $10 \%, 14 \%$ ja $17 \%$. Heinän raakavalkuaisesta on oletettu sulavan $63 \%$, säilörehun vastaavasti $70 \% \cdot{ }^{1}$ )

Ruokintaan tuleva rehuyksikkömäärä on kuivana korjattavan heinän osalta laskettu em. tappiolla vähennetystä kuiva-ainemäärästä jakamalla täyttävyysluvulla 1.9, joka rehutaulukoissa on ilmoitettu kukinnan keskivaiheilla korjatun timoteiheinän täyttävyydeksi.

AIV-säilörehuksi korjatun ruohon täyttävyydeksi on PoIJÄrvI (1955) ilmoittanut 1.6 (mikä edellyttää $7.1 \mathrm{~kg}$ säilörehua 1 ry kohden), mutta on esittänyt vaihtoehdon 1.36 , korvausluvun ollessa $6.1 \mathrm{~kg}$. Luvut ovat $23 \%$ apilaa sisältävästä timoteinurmesta, jonka sadon kuiva-aineessa on $29.3 \%$ raakakuitua. Uudemmissa rehutaulukoissa esitetään $1 / 4$ apilaa sisältävästä nurmesta saatavan AIV-rehun täyttävyydeksi 1.5 (Maatalouskalenteri 1966, p. 240). Sulavaa raakavalkuaista on mainittu olevan $119 \mathrm{~g}$ ja korvausluku 7.0. NoRDFELDT $(1966$, p. $243-244)$ esittää $27.0 \%$ raakakuitua sisältävän timotei- ym. säilörehun täyttävyydeksi 1.48 , korvausluvun ollessa 5.9 ja srv.pitoisuuden $153.4 \%$. Eräissä myöhemmissä tutkimuksissa esiintyy vielä edullisempia täyttävyyslukuja. Niinpä BREIREM (1967) esittää tähkien puhjetessa korjatun timoteisäilörehun täyttävyydeksi 1.33 , kuiva-aineen sisältäessä raakavalkuaista $8.2 \%$. Eräässä HyPPöLÄn laatimassa graafisessa esityksessä todetaan $29.3 \%$ raakakuitua sisältävien tuoreiden karkearehujen täyttävyydeksi 1.41. (K. HYРPöLÄ, kommunikaatio 22. 5. 1968).

Kysymys lienee suurelta osalta siitä, millä asteella säilörehuksi korjattu timoteiruoho on katkaistu. AIV-rehua valmistettaessa pyritään lähinnä odelmasatojen ja ennen normaalia heinän korjuuta niitettävien aikaissatojen hyväksikäyttöön. Näillä voitaneen hyvin puoltaa alempaa täyttävyyslukua, esim. 1.4. Tämän tutkimuksen kannalta on valitettavaa, että erityisesti pohjoissuomalaisen timoteiruohon rehuopillisia ominaisuuksia ei liene sulavuus-ja maidontuotantokokeilla selvitetty. Tiedetään myös ehkä liian vähän nousevien lan-

1) Koska puheenaolevissa koeolosuhteissa suoritetuissa kuiva-ainemääräyksissä prof. ORvo RrNGin ilmoittaman käsityksen mukaan on systemaattista virhettä, on alkuperäisiä raakavalkuaisprosentteja ennen ravintoainetappioita korjattu hänen suosittelemallaan kertoimella 0.96 . 


\begin{tabular}{|c|c|c|}
\hline & 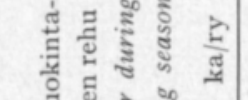 & 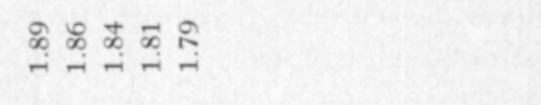 \\
\hline$\frac{2}{8}$ & 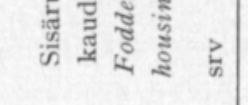 & 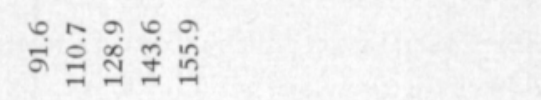 \\
\hline 递 & 结 & ن \\
\hline 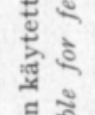 & 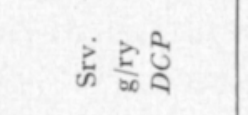 & 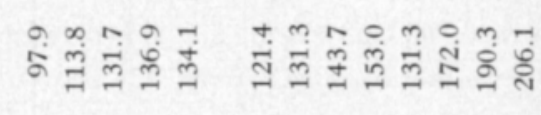 \\
\hline 结 & & 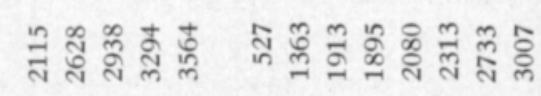 \\
\hline 遂 & & 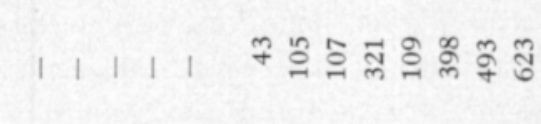 \\
\hline 窟 & & 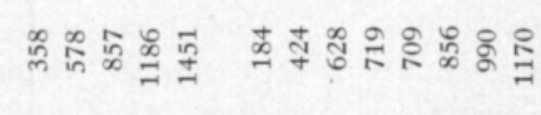 \\
\hline & & 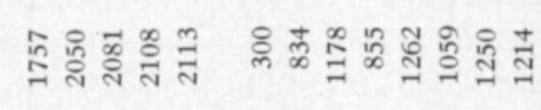 \\
\hline & 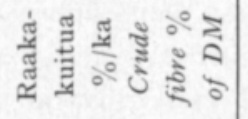 & 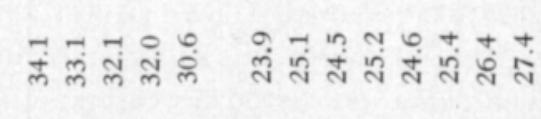 \\
\hline & & 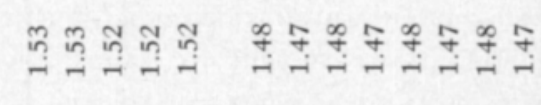 \\
\hline & $\dot{E} \frac{\vec{H}}{\infty}$ & 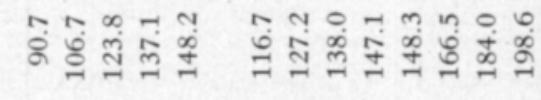 \\
\hline$\frac{1}{2}$ & 荒 总 & 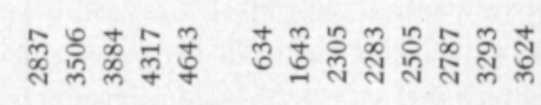 \\
\hline $\begin{array}{ll}0 \\
0\end{array}$ & 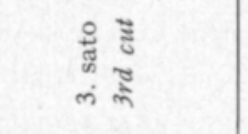 & 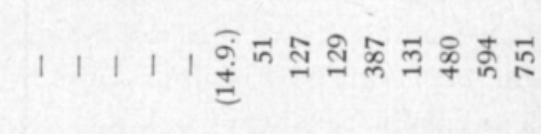 \\
\hline & 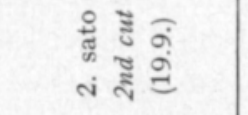 & 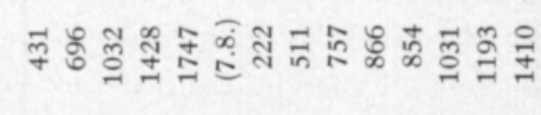 \\
\hline & 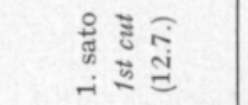 & 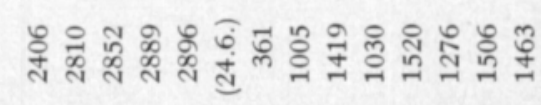 \\
\hline & 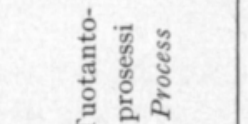 & : \\
\hline
\end{tabular}


noitemäärien vaikutuksesta täyttävyyslukuihin. Todettakoon kuitenkin, että Perä-Pohjolan, samoinkuin Etelä-Savonkin koeaseman kokeissa nousevat typpimäärät eivät ole mainittavasti vaikuttaneet raakakuidun suhteelliseen määrään nurmen sadossa (vrt. edellä p. 381).

Tämän tutkimuksen ensimmäisissä koelaskelmissa sovellettiin timoteiAIV-rehulle täyttävyyslukua 1.6. Lopullisissa laskelmissa otettiin kuitenkin käytäntöön täyttävyysluku 1.4, koska haluttiin erityisesti selvitellä kehittyneemmän tekniikan taloudellista merkitystä. Alempana esitetyssä koelaskelmassa B. on verrattu näiden täyttävyyslukujen vaikutusta ruokintasuunnitelman muotoutumiseen.

Alemman täyttävyysluvun käyttäminen edellyttäisi joko rehuyksikkösadon säilytystappioiden arvioimista edellämainittuja PoIJÄRvEN lukuja pienemmiksi tai suurempia rehuyksikköarvoja nurmen tuoresadolle. Seuraavassa esityksessä on rehuyksikkömäärä kuitenkin kauttaaltaan laskettu epäedullisempaa täyttävyyslukua käyttäen. Tässä esiintyy pieni epäjohdonmukaisuus, jolla ei kuitenkaan liene sanottavaa käytännöllistä merkitystä. Jos edullisemmat täyttävyysluvut eivät tarkoin vastaisi koeolosuhteita, voitaisiin ajatella, että ne olisivat toteutumismahdollisia korjuun tapahtuessa jonkinverran aikaisemmin, mikä taas edellyttäisi pienempiä tuoresatoja.

Taulukossa 11 esitetyt sulavan raakavalkuaisen pitoisuudet, arvioituina edellä mainittujen PoIJÄRven lukujen perusteella, on esitetty erikseen tuoresadosta ja säilytyksen jälkeen käytettävissä olevasta sadosta. Koska laidunrehun tarve syyskesällä on tavallisesti tyydytettävä suurelta osalta odelmalla, on kuivana korjatun heinän jälkeen käytettävissä oleva odelma tietyltä osalta, joka tässä on arvioitu 300 rehuyksiköksi hehtaarilta, edellytetty aina laidunnettavaksi. Kun tämä osa on poissa talvikauden ruokinnasta, jota varten ruokintasuunnitelma on eläinten fysiologisten tarpeiden mukaisesti tehtävä, on sekä valkuais- että täyttävyysluvut näiden tuotantoprosessien osalta esitetty kahdessa viimeisessä sarakkeessa erikseen. Näitä lukuja on käytetty rehun laatua kuvaavina osoittimina.

Taulukosta 11 nähdään, miten toisaalta lannoitteiden käytön lisääntyminen, toisaalta säilörehun osuuden kasvaminen on voimakkaasti suurentanut sulavan raakavalkuaisen määrää rehuyksikköä kohden. On arvattavissa, että tällä on ruokinnan taloudellista suunnittelua silmällä pitäen tärkeä merkitys etenkin siinä todennäköisesti mahdollisessa tapauksessa, että valkuaisrikkaiden rehujen hinnat ovat korkeampia kuin hiilihydraattirikkaiden rehujen hinnat.

Mutta myöskin täyttävyyslukujen eroavuuksilla saattaa tuotantoprosessien valinnassa olla taloudellista merkitystä varsinkin silloin, kun täyttävyysasteiltaan erilaisten rehujen hinnat tai tuotantokustannukset ovat eri tasoilla.

\section{Nurmenviljelyn vaihtoehtoisten tuotantoprosessien vertailu}

Alustavaan tarkasteluun otetaan-tässä kolmetoista, osaksi sadonkorjuumenetelmän; osaksi lannoituksen perusteella erilaista timotei-nurminatanurmen tuotantoprosessia, joiden luku kaksinkertaistuu, kun otetaan huomioon myös työtekniikan asteet. Ne on muodostettu Perä-Pohjolan koeaseman nur- 
menviljelykokeiden koejäsenistä, osaksi niitä yhdistellen. Niiden työnmenekkiluvuista ja sadoista on erältä osin esitetty arvioluvut edellä (p. 374) ja lannoituskustannuksista on esitetty tietoja asetelmasta (p. 383) ja Taulukossa 11 (p. 385). Nurmenviljelyä perustettaessa on työkustannusten lisäksi, joka on huomioitu vuotuisissa työnmenekkiluvuissa, sijoitettava varoja siementen hankintaan. Normaali turvemaan siemenseos käsittää $22 \mathrm{~kg}$ timoteita ja $6 \mathrm{~kg}$ nurminataa ha kohden. Kilohintojen ollessa 4:30 ja 3:92 päädytään näistä määristä n. 120 markan kustannukseen. Jos tämä jaetaan 5 vuoden osalle, saadaan $24 \mathrm{mk}$ vuotta kohden.

Heinänkorjuussa käytetään yleensä säilymisen ja maun parantamiseksi n. $1 \%$ heinän painosta vastaava suolamäärä. Hinnan ollessa $8 \mathrm{p} / \mathrm{kg}$ tullaan tästä kustannuserään, joka vastaa $0.2 \mathrm{p}$ heinärehuyksikköä kohden.

AIV-menetelmää sovellettaessa käytetään apilaköyhillä nurmilla n. 1.2 $\mathrm{kg}$ tai silputustekniikkaa sovellettaessa $0.7 \mathrm{~kg}$ väkevää AIV-liuosta $100 \mathrm{rehu-}$ kiloa kohden. Kun liuoksen hinnaksi lasketaan $30 \mathrm{p} / \mathrm{kg}$, päädytään tästä 2.5 tai 1.7 p rehuyksiköltä vastaavaan kustannukseen.

Säilörehutornista aiheutuvien vuotuiskustannusten voidaan aikaisemmin (p. 379) esitetyllä tavalla arvioida vaihtelevan rajoissa $1.6-2.4 \mathrm{p} / \mathrm{ry}$, ja voinemme jonkinlaisena keskiarvona soveltaa lukua $2.1 \mathrm{p} / \mathrm{ry}$.

Traktoritekniikassa mahdollisen niittosilppurin konekustannukset voidaan myös edellä (p. 379) esitetyllä tavalla arvioida keskimäärin 1.7 penniksi kilolta.

Alustavissa laskelmissa on käytettävä tarkoituksenmukaisilta tuntuvia arviohintoja (varjohintoja) niille muuttuville kustannuksille, joita aiheutuu talouden sisäisistä suorituksista. Kuten sivulla 378 on mainittu, on ihmistyölle käytetty hintaa 2:- tunnilta ja hevostyön muuttuva kustannus on arvioitu sen mukaan, miten hevosen työssä käyttäminen on lisännyt hevosenpidon kustannuksia.

Vertailtavien tuotantoprosessien hehtaaria kohden lasketut muuttuvat kustannukset sisältyvät Taulukkoon 12. Nämä on tarkoitettu otettavaksi huomioon lopullisia tuotantosuunnitelmia varten tehdyissä LP-taulukoissa. ${ }^{1}$ )

Tätä kustannuserää ei sensijaan ole otettu lukuun tuotantoprosessien alustavaa vertailua varten lasketuissa kustannuksissa rehuyksikköä kohden, jotka nähdään taulukon alaosassa. Näitä kustannuksia laskettaessa on pyritty määrittämään lähinnä sisäruokintakautta varten tuotettujen rehujen tuotantokustannus. Tästä syystä on työnkäytön kiinteää osaa arvioitaessa vähennetty laitumena käytettäväksi oletetun odelmasadon osuus, muun työnemenekin tullessa jaetuksi vain talviruokintaan tulevien rehuyksiköiden luvulla.

Tuotantoprosessien edullisuutta vertailtaessa kiinnitetään ensiksikin huomiota kahdella alimmalla rivillä esitettyihin lukuihin, jotka osoittavat tällä tavoin alustavasti laskettujen muuttuvien kustannusten suuruutta penneinä rehuyksikköä kohden, erikseen tekniikassa I ja II. Toteamme että nämä kustannukset yleensä nousevat lannoitusintensiteetin kohotessa. Tässä joudutaan mahdollisesti kysymään, ovatko käyttämämme arviomenetelmät eri-

1) Laadituissa LP-taulukoissa on joitakin poikkeamia tämän taulukon luvuista. Tietokoneen laskemia katetuottoja on kuitenkin tässä julkaisussa korjattu täyden yhdenmukaisuuden saavuttamiseksi tässä esitettyjen peruslukujen kanssa. 
tyisesti työnmenekin osalta johtaneet korkeamman intensiteetin edullisuutta väheksyvään suuntaan. Tähän ei tietenkään ole tietoisesti pyritty, mutta toisaalta ei hypoteesia tiettyjen sadonkorjuutöiden lisäyksestä samassa suhteessa kuin hehtaarisatokin ole voitu kokemusperäisillä tiedoilla verifioida.

Yksinomaan säilörehuntuotantoon suuntautuvissa C- ja D-sarjan tuotantoprosesseissa ei lannoituskustannusten ja satojen muutos tapahdu kaikissa tapauksissa samansuuntaisesti. Vaikka satunnaisuuksilla saattaa olla vaikutuksensa joka koejäsenessä, olemme kuitenkin alustavassa karsinnassa poistaneet ne tuotantoprosessit, joissa kustannus ry:ä kohden poikkeaa jatkuvan kustannuskäyrän edellyttämistä arvoista. Siten on prosessit $C_{1}, C_{3}$ ja $D_{1}$ jätetty jatkokäsittelyssä pois, samoin kovin alhaisia satotuloksia lannoittamattomalla maalla edellyttänyt vaihtoehto $C_{0}$.

Kun rehuyksikön tuotannon muuttuvat kustannukset, joihin tässä ihmistyönkin kustannus on sisällytetty, nousevat korkeimpiin lannoitustasoihin siirryttäessä, voidaan korkeampaa intensiteettiä suositella lähinnä siinä tapauksessa, että rehun suurempi raakavalkuaisen määrä riittävästi kohottaa rehun arvoa ruokinnassa. Alempana keskitytään tarkastelemaan tarkoituksenmukaisen ruokintasuunnitelman vaatimuksia rehun laatuun nähden.

\section{Laidunrehun tuotantoprosessit}

Meillä yleisesti sovelletun tuotantotekniikan puitteissa katsotaan edulliseksi tyydyttää mahdollisimman suuri osa lypsylehmien rehuntarpeesta laiduntamalla. Laidunruokinnalle asettavat kuitenkin ilmastolliset edellytykset ylärajan, joka Pohjois-Suomessa on alempana kuin suurimmassa osassa maatamme. Laiduntamista varten perustettu heinänurmi, jonka ruohontuotanto syksyyn mennessä säännönmukaisesti alenee ja sääsuhteista riippuen voi tuntuvasti vaihdella, vaatii tarkoin suunniteltua laiduntamista. Tähän liittyy myös mahdollisen kevätkesällä esiintyvän ylijäämän talteenotto säilörehuksi valmistamalla, jotta saataisiin edullisin tuotos hehtaaria kohden. Toisaalta on osattava järjestää syöttö niin, että eläinten käyttämä rehuyksikkömäärä muodostuu mahdollisimman suureksi, mikä ei liian tarkkaan syöttöön pyrittäessä aina onnistu. Erityisesti korkeampia päivätuotoksia tavoiteltaessa lienee tyydyttävä jonkin verran pienempään rehuyksikkösatoon hehtaarilta kuin minkä nurmi voisi antaa, mutta laitumen käyttöä voitaisiin tehostaa järjestämällä jälkisyöttöä alempituottoisilla eläimillä (vrt. GorDon et al. 1966, p. 120-125).

Tarkoituksenmukaisesti syötetyn laidunnurmen rehuyksikkösato voitaneen arvioida suunnilleen samaksi kuin heinänkorjuulla tai AIV-rehun valmistuksella samalta alueelta saatava sato. Jos kohta laidunnettaessa vältetään rehun säilytyksessä tapahtuvat tappiot, laidunruohoa jää toisaalta helposti yli-ikäiseksi, josta syystä ehkä tuntuvakin hukkaprosentti; liian tarkka syöttäminen puolestaan vähentää kasvua, jolloin mahdollisesti syntyy säilytyshäviön suuruinen tuotosvajaus.

JÄRVEN (1967, p. 202-203) mukaan on Laidunyhdistyksen tarkkailulaitumilta Lapin läänissä vv. $1960-65$ saatu rehua 2545 ry ja maitoa tuotettu $3396 \mathrm{~kg}$ hehtaarilta, keskimääräisen lannoituksen ollessa $111 \mathrm{~kg} \mathrm{~N}, 65 \mathrm{~kg} \mathrm{P}_{2} \mathrm{O}_{5}$ 


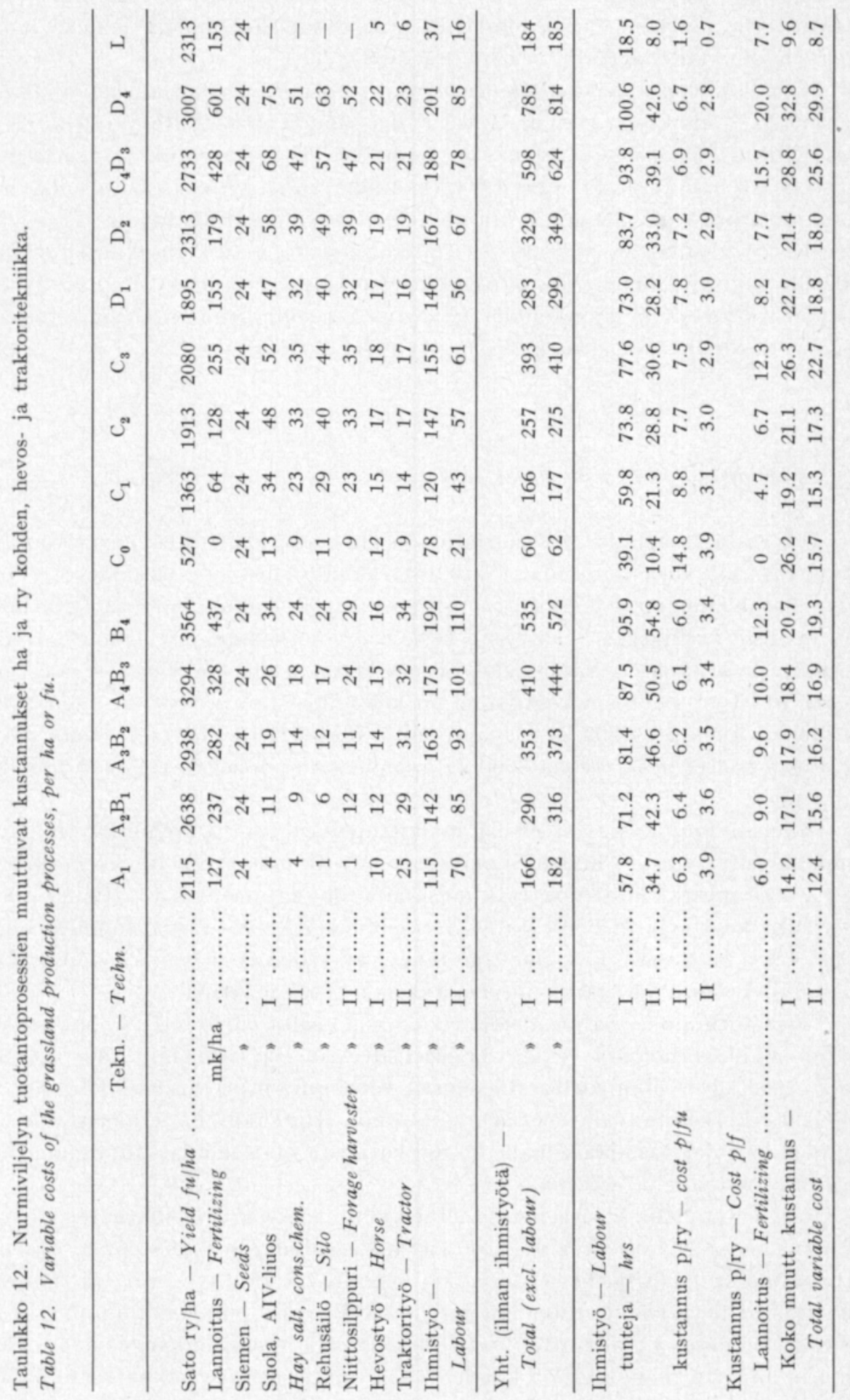


ja $86 \mathrm{~kg} \mathrm{~K} \mathrm{~K}_{2} \mathrm{O}$ hehtaaria kohden. Esitettyjen lukujen perusteella voidaan laskea, että lehmien keskimääräinen päivätuotos 109 vuorokautta käsittävänä laidunkautena on näillä laitumilla ollut $7.9 \mathrm{~kg}$ ja rehuyksikkömäärä lehmää kohden koko laidunkautena 636 ry (päivässä 5.83 ry).

Perä-Pohjolan kokeiden 'koejäsenessä $\mathrm{D}_{2}$ on rehuyksikkösadoksi hehtaarilta saatu, AIV-rehuksi säilöttynä, $2313 \mathrm{ry} /$ ha lannoituksen ollessa $110 \mathrm{~kg} \mathrm{~N}, 75$ $\mathrm{kg} \mathrm{P}_{2} \mathrm{O}_{5}$ ja $90 \mathrm{~kg} \mathrm{~K}_{2} \mathrm{O}$. Se vastaa näinollen sekä lannoituksensa etțä rehuyksikkösatonsa puolesta JÄRVEN tarkkailulaitumia. Viimeksimainituilla laitumilla on lehmiä päivätuotannosta päätellen keskimäärin laidunnettu lypsykauden keskivaiheilla tai sen jälkeen. On mahdollista, että laidunkausi tutkimusalueella saattaisi muodostua pitemmäksi kuin Lapin läänin laitumilla. Laidunkauden pituuden ja ajankohdan vaikutusta ruokintasuunnitelmaan tarkastelemme alempana koelaskelmassa C (p. 399).

\section{Lypsykarjan ruokintaa koskevat laskelmat}

Tehtäessä laskelmia lypsykarjataloudesta on syytä lähteä niistä tuotantoluvuista, joita alueella toimivien karjantarkkailuyhdistysten keskiarvot edustavat. Laskelmiemme pohjaksi on otettu Kajaanin, Oulun läänin ja Perä-Pohjolan mvs:jen keskiarvot, sekä niistä keskiarvoa korkeampi- ja alempituottoisten lehmien keskitulokset. Nämä tulokset on esitetty edellä (p. 360) olevassa Taulukossa 10. Lypsylehmien keskipaino on koko aineiston perusteella ollut $376 \mathrm{~kg}$ ja maidon tuotanto $3200 \mathrm{~kg}$ rasvaprosentin ollessa 4.13. Parempi puolisko aineistosta pääsee keskiarvoon $3600 \mathrm{~kg}$ huonomman puoliskon jäädessä $2800 \mathrm{~kg}: \mathrm{n}$ vaiheille.

Samassa taulukossa on edellä mainittujen tuotos- ja rehunkäyttölukujen rinnalla esitetty myös niiden Suomussalmen tutkimusalueen tilojen keskiarvot, joilta karjantarkkailutiedot tutkimusajalta on käytettävissä. Näillä tiloilla on saatu keskimäärin $3500 \mathrm{~kg}$ maitoa lehmää kohden, rasvaprosentin ollessa jopa $4.9 \%$ :n tasoa. Elopainot ja rehunkäyttöluvut ovat korkeampia kuin maanviljelysseurojen tarkkailuyhdistyksissä keskimäärin.

Tässä tutkimuksessa on maidontuotannon osalta edellytetty kolme erilaista $4 \%$ :n maidon tuotosta vastaavaa intensiteettitasoa, nimittäin $2800 \mathrm{~kg}, 3200$ $\mathrm{kg}$ ja $3600 \mathrm{~kg}$. Kuten edellisestä selviää, tutkimusalueen tarkkailukarjojen taso on lähes korkeinta vaihtoehtoa vastaavaa. Kuitenkin on otaksuttava, että muiden karjojen taso jää sen alle, ja osa karjoista saattaa olla alinta mainituista tasoista vastaavalla asteella.

Jos edellytetään, että heinä on ollut kukinnan keskivaiheilla niitettyä timoteiheinää ja sisälțänyt siten $91 \mathrm{~g}$ sulavaa raakavalkuaista ry:ä kohden, öljyväkirehu $340 \mathrm{~g}$ srv/ry sisältävää, viljaväkirehuohraa à $75 \mathrm{~g}$ srv, väkevä tuorerehu naattinaurista sekä täyttävä tuorerehu AIV-rehua, niin rehutaulukoissa esitettyjen lukujen nojalla päädytään siihen, että tarkkailukarjoissa on keskimäärin annettu rehuyksikköä kohden $127 \mathrm{~g}$ sulavaa raakavalkuaista ja $1.54 \mathrm{~kg}$ kuiva-ainetta. Käytetty rehuyksikkömäärä on jotenkin tarkkaan ruokintanormien mukainen. 
Suomussalmen karjoissa olisi yllämainituin edellytyksin käytetty vain 121 g srv/ry, kuiva-ainemäärän eli täyttävyyden ollessa talviruokintakautena $\mathbf{1 . 5 3}$.

Tarkkailukarjojen keskiarvoja ei voi pitää täysin luotettavana perustana taloudellisia laskelmia laadittaessa. Ne kuvastavat enemmän ruokintasuunnitelmien laatijoiden ehdotuksia kuin todellista ruokintaa. Käytännössä rehun käyttö muodostuu epätaloudellisemmaksi kuin tarkasti suunnitelluissa ruokintakokeissa. Tanskassa on ero teoreettisen ja kirjanpitotiloilla havaitun todellisen kulutuksen välillä havaittu $14 \%$ :ksi (VitTING-ANDERSEN 1966). Tässä tutkimuksessa on pitäydytty yksinomaan normeihin, joten lasketut tulokset saattavat olla todellista parempia.

Rehun suhteellinen arvo maidontuotannossa riippuu ensi sijassa kahdesta tuotantoon vaikuttavasta tekijästä, sulavan raakavalkuaisen määrästä rehuyksikköä kohden sekä sen täyttävyydestä, ts. kuiva-ainemäärästä ry:ä kohden. Edellisen osalta on asetettu lähinnä minimiä vastaava normi (joka tosin on jossain määrin venyvä), jälkimmäisen osalta sekä minimi että maksimi, joskin taloudellista merkitystä on vain maksimilla ${ }^{1}$ ). Erityisesti korkeampien päivätuotantojen kohdalla ruokinnan järjestelyä rajoittaa se tosiasia, että päiväannoksen kuiva-ainemäärä on rajoitettu, joten tuotannon kohotessa on pakko käyttää suhteellisesti enemmän tavallisesti kalliimpia konsentroituja rehuja.

Ruokintasuunnitelmissa vaikuttaa edullisimpaan rehuyhdistelmään myös lypsylehmän maidontuotantokäyrän muoto. Tätä on kuvattu yksinkertaisimmin luvulla, joka osoittaa, montako prosenttia viiden ensimmäisen tuotantokuukauden maitomäärä on koko vuoden tuotannosta. PALoheimo (1956, p. 455) esittää verraten edullisena suhteena $55 \%$, vähemmän edullisena $68-69 \%$.

Laadittaessa ruokintanormeihin perustuvia suunnitelmia asettamaamme tutkimustehtävää varten lienee paikallaan jakaa tuotantokausi 3:een osaan: 5 ensimmäistä kuukautta, 6 seuraavaa kuukautta, jona esiintyy tuotantoa sekä ehdyksissäolokuukausi, jolloin ruokinta käsittää vain elatusrehua sekä sikiön kasvattamiseen tarvittavan ravinnon.

Tarkkailukarjojen keskituotannot voidaan ajatella saavutettavaksi vaihtoehtoisesti »edullisen» ja »epäedullisen» tuotantokäyrän vallitessa, jolloin 3200 kg:n tulos voidaan saavuttaa keskimääräisten päivätuotantojen ollessa tuottavilla jaksoilla joko $14.9 \mathrm{~kg}$ ja $5.3 \mathrm{~kg}$ tai $11.7 \mathrm{~kg}$ ja $8.0 \mathrm{~kg}$. Vuosituotanto 3600 $\mathrm{kg}$ voidaan saavuttaa esim. $14.9 \mathrm{~kg}: \mathrm{n}$ ja $8.0 \mathrm{~kg}: \mathrm{n}$ keskituotannolla, ja esim. 2800 kg:n vuosituotantoon päästään päivätuotannoilla $11.7 \mathrm{~kg}$ ja $5.3 \mathrm{~kg}$. Edellyttäen elopainoksi $376 \mathrm{~kg}$ ja rasvaprosentiksi 4,3, mikä vastaa Kajaanin osuusmeijerin vastaanottaman maidon rasvapitoisuutta saadaan ruokintanormien mukaan (Maatalouskalenteri 1966, p. 195) seuraavat ravinnontarvetta koskevat luvut:

1) Käytettäessä täyttävyyslukujen inverssiarvoja, so. väkevyyslukuja, jotka JänNES aikanaan esitti käytäntöön otettaviksi, relevantiksi tulee minimi. 


\begin{tabular}{|c|c|c|c|c|c|c|}
\hline $\begin{array}{l}\text { Päivä- } \\
\text { tuotanto } \\
\text { Production } \\
\text { per day } \\
\text { kg }\end{array}$ & $\begin{array}{c}\text { Rehuyksikkō } \\
f . u .\end{array}$ & $\begin{array}{c}\text { Sulavaa } \\
\text { raakavalk. } \\
D C P \\
g\end{array}$ & $\begin{array}{c}\text { Kuiva- } \\
\text { ainetta } \\
\text { Dry matter } \\
\text { kg }\end{array}$ & $\begin{array}{c}\text { Srv/ry } \\
D C P / f . u .\end{array}$ & $\begin{array}{l}\text { K.a./ry } \\
D M \mid f . u .\end{array}$ & $\begin{array}{c}\text { Väkevyys- } \\
\text { luku } \\
\text { Conc. }\end{array}$ \\
\hline 14.9 & 8.66 & 1137.3 & 12.12 & 0.1313 & 1.40 & 0.7142 \\
\hline 11.7 & 7.45 & 949.5 & 11.17 & 0.1274 & 1.50 & 0.6669 \\
\hline 8.0 & 6.04 & 733.5 & 9.66 & 0.1214 & 1.60 & 0.6253 \\
\hline 5.8 & 5.22 & 605.3 & 8.87 & 0.1160 & 1.70 & 0.5885 \\
\hline 5.3 & 5.03 & 576.8 & 8.55 & 0.1147 & 1.70 & 0.5883 \\
\hline 0.0 & 4.75 & 590.0 & 8.55 & 0.1242 & 1.70 & 0.5555 \\
\hline
\end{tabular}

\section{Laiduntuotannon kausivaihtelun huomioonottaminen}

Siihen nähden, että laitumelta saatava rehu yleensä, ja todennäköisesti myös tutkimusalueen olosuhteissa, kaipaa vähemmän täydennystä valkuaismäärän ja väkevyyden suhteen kuin talviruokinnassa käytettävät karkeat rehut, maidontuotannon jakaantumisella laidunkauden ja sisäruokintakauden kesken on laskelmiemme kannalta varteenotettava merkitys. Maidontuotannon vaihteluista tiloilla ei ole suoranaisia tietoja käytettävänä. Sitävastoin on ollut mahdollisuus käyttää maataloustilaston mukaisia Kajaanin mvs:n alueella olevien meijerien kuukausittaisia vastaanottomääriä sekä Kajaanin osuusmeijerin ilmoittamia tietoja asianomaisten maidonlähettäjien kuukausittaisista toimituksista meijerille. Niistä voidaan laskea laidunkauden ja sisäruokintakauden keskimääräiset maidontoimitukset suhdelukuina, joissa vuoden keskimääräistä päivittäistä toimitusta on merkitty 100:lla. Maidon käytön kotitalouksissa voitaneen arvioida pysyneen suunnilleen samana vuoden ympäri ja tässä arvioinnissa voitaneen soveltaa maaseudun kulutustutkimuksessa selvitettyjä keskim. kulutusmääriä, joista on mainittu tutkimusryhmän pääraportin sivuilla $57-59$ (Finnish Study Group, 1969). Lisättäessä kotikulutus tullaan allaolevan asetelman viimeisessä sarakkeessa esitettyihin suhdelukuihin, joita käytämme tässä maidontuotannon kausivaihtelun mittana.

\begin{tabular}{|c|c|c|c|c|c|}
\hline & $\begin{array}{c}\text { Kajaanin mvs:n } \\
\text { meijerien maidon } \\
\text { vastaanottomäärät } \\
1959-63 \\
\text { Milk receipts of } \\
\text { frovincial dairies }\end{array}$ & $\begin{array}{l}\text { Tutkim } \\
\text { toimit } \\
\text { Milk deli } \\
\text { Ryhmä } \\
\text { Group } \\
\text { A }\end{array}$ & $\begin{array}{l}\text { ustilojen } \\
\text { ukset } 195 \\
\text { eries of st } \\
\text { Ryhmä } \\
\text { Group } \\
\text { B }\end{array}$ & $\begin{array}{l}\text { maidon- } \\
9-63 \\
\text { dy farms } \\
\text { Keskim. } \\
\text { Aver. }\end{array}$ & $\begin{array}{c}\text { Tutkimustilojen } \\
\text { arvioitu maidon- } \\
\text { tuotanto keskim } \\
\text { Estimated } \\
\text { production }\end{array}$ \\
\hline $\begin{array}{l}\text { Koko vuosi ................... } \\
\text { Whole year }\end{array}$ & 100 & 100 & 100 & 100 & 100 \\
\hline $\begin{array}{l}\text { Laidunkausi ................ } \\
\text { Pasture season }\end{array}$ & 117.2 & 121.7 & 111.9 & 116.9 & 113.4 \\
\hline $\begin{array}{l}\text { Sisäruokintakausi ........ } \\
\text { Winter feeding season }\end{array}$ & 94.4 & 89.2 & 94.0 & 91.5 & 93.2 \\
\hline
\end{tabular}

Edellytettäessä ennenmainitut kolme tuotantotasoa saamme allaolevat keskimääräiset päivätuotannot laidun- ja sisäruokintakaudella. Niitä vastaavat rehuyksikkö-, sulavan raakavalkuaisen ja kuiva-aineen määrät ynnä väkevyysluvut esitetään myöskin asetelmassa. 


\begin{tabular}{|c|c|c|c|c|c|c|c|c|}
\hline & $\begin{array}{c}\text { Tuotantotaso } \\
\text { Production level } \\
\text { kg }\end{array}$ & $\begin{array}{l}\text { Päivä- } \\
\text { tuotanto } \\
\text { Milk per } \\
\text { day } \\
\text { kg }\end{array}$ & $\begin{array}{l}\text { Rehuyks. } \\
\text { f.u. }\end{array}$ & $\begin{array}{c}\text { Sulavaa } \\
\text { raaka- } \\
\text { valk. } \\
D C P\end{array}$ & $\begin{array}{l}\text { Kuiva- } \\
\text { ainetta } \\
\text { Dry } \\
\text { matter }\end{array}$ & $\begin{array}{c}\text { Srv/ry } \\
D C P / f . u .\end{array}$ & $\begin{array}{l}\mathrm{K} \cdot \mathrm{a} \cdot / \mathrm{ry} \\
D M / f \cdot u\end{array}$ & $\begin{array}{c}\text { Väke- } \\
\text { vyysluku } \\
\text { Conc. }\end{array}$ \\
\hline \multirow[t]{2}{*}{3200} & 1. $1 . \ldots \ldots$ & 9.95 & 6.78 & 837 & 10.2 & 0.1235 & 1.50 & 0.6669 \\
\hline & s. . ................... & 8.17 & 6.10 & 733 & 9.8 & 0.1202 & 1.60 & 0.6253 \\
\hline \multirow[t]{2}{*}{3600} & g $1 . \quad \ldots \ldots \ldots \ldots \ldots \ldots \ldots$ & 11.34 & 7.31 & 918 & 10.2 & 0.1256 & 1.40 & 0.7142 \\
\hline & s. ....................... & 9.32 & 6.54 & 800 & 9.8 & 0.1223 & 1.50 & 0.6669 \\
\hline \multirow[t]{2}{*}{2800} & 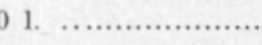 & 8.70 & 6.31 & 764 & 9.5 & 0.1211 & 1.50 & 0.6669 \\
\hline & s. ...................... & 7.15 & 5.72 & 673 & 9.2 & 0.1177 & 1.60 & 0.6253 \\
\hline
\end{tabular}

\section{Ensimmäinen LP-laskelma. Koelaskelma A.}

Erilaisia päivätuotantoja vastaavan rehun kokoonpano on nyt määrätty lineaarista suunnittelua soveltamalla. Viljelmällä tuotettu karkea rehu on edellytetty täydennettäväksi öljykakkuseoksella, joka sisältää sulavaa raakavalkuaista $340 \mathrm{~g} / \mathrm{ry}$ ja jonka täyttävyys on 0.95 (väkevyysluku 1.053) sekä hinta -:55/ry, ynnä ohralla (75 g srv/ry, täyttävyys 0.95 , väkevyysluku 1.053), jonka hinta on $-: 34 / \mathrm{kg}$ ynnä jauhatuskuluja $2 \mathrm{p} / \mathrm{kg}$. Rehutaulukoista saadaan ohralle jonkinverran pienempi täyttävyys, mutta oletamme rehuohran joka saattaa olla osaksi alueella tuotettua - olevan laadultaan heikompaa kuin keskimääräinen ohra.

Kun keskinkertaisen laidunruohon sulavan raakavalkuaisen määrä on kalenterinormien mukaan $163 \mathrm{~g} /$ ry ja väkevyysluku $1 / 1.3$ eli 0.77 , näyttää siltä, ettei väkirehun käyttö laidunkautena keskimäärin ottaen ole lainkaan tarpeen (paitsi tietenkin korkeiden, esim. yli $20 \mathrm{~kg}$ päivätuotantojen jaksoina).

Ohjelma on sisäruokintakauden aikana käytetyn rehun osalta laadittu asettamalla asetelmissa sivulla 392 mainitut vähimmäisvaatimukset kutakin päivätuotantoa vastaavan sulavan raakavalkuais- ja väkevyysluvun kohdalta ja minimoimalla rehuannoksen ry-hinta yllämainittuja väkirehun hintoja sekä edelläselostettujen eri lannoitusvaihtoehtojen muuttuvia kustannuksia C-tekijänä käyttäen.

Esimerkiksi 14.9 kg:n päivätuotantoa varten lasketaan rehuyksikkömäärän jakaantuminen sisäruokintakautena käyttäen seuraavia epäyhtälöitä (hevosen käyttöön perustuva tekniikkaa):

Valkuaisrajoitus:

(1) $0.340 \mathrm{X}_{1}+0.075 \mathrm{X}_{2}+0.0913 \mathrm{X}_{3}+0.1109 \mathrm{X}_{4}+0.1284 \mathrm{X}_{5}+0.1433 \mathrm{X}_{5} \geqq 0.1313$

Väkevyysrajoitus:

(2) $1.053 \mathrm{X}_{1}+1.111 \mathrm{X}_{2}+0.5291 \mathrm{X}_{3}+; 0.5348 \mathrm{X}_{4}+0.5435 \mathrm{X}_{5}+0.5510 \mathrm{X}_{3} \geqq 0$

Määräyhtälö:

(3) $\mathrm{X}_{1}+\mathrm{X}_{2}+\mathrm{X}_{3}+\mathrm{X}_{4}+\mathrm{X}_{5}+\mathrm{X}_{6}=1.00$

Kustannusten minimointiyhtälö:

(4) $55 \mathrm{X}_{1}+36 \mathrm{X}_{2}+14.8 \mathrm{X}_{3}+17.6 \mathrm{X}_{4}+18.5 \mathrm{X}_{5}+20.2 \mathrm{X}_{6}=$ Min. 
Suunnittelun ratkaisut ovat ensimmäisessä vaiheessa johtaneet seuraaviin tuloksiin, joiden yhteydessä alimmalla intensiteettiasteella tuotettu perusrehu on osoittautunut taloudellisimmaksi:

$\%$ sisäruokintakauden ry-määrästä

$\begin{array}{ccccccc}\begin{array}{c}\text { Päivätuot. } \\ \begin{array}{c}\text { Production } \\ \text { per day }\end{array}\end{array} & \begin{array}{c}\text { Öljy- } \\ \text { kakkuja } \\ \text { Oil cakes }\end{array} & \begin{array}{c}\text { Ohraa } \\ \text { Barley }\end{array} & \begin{array}{c}\text { Heinää }+ \\ \text { AIV-rehua } \\ \text { Hay+silage }\end{array} & \begin{array}{c}\text { Siitä heiniä } \\ \text { Hay }\end{array} & \begin{array}{c}\text { Siitä } \\ \text { AIV-rehua } \\ \text { Silage }\end{array} & \begin{array}{c}\text { Rehun hinta } \\ \text { Price }\end{array} \\ 14.9 & 17.3 & 18.1 & 64.7 & 62.6 & 2.1 & 27.4 \\ 11.7 & 15.2 & 11.1 & 73.7 & 71.3 & 2.4 & 25.4 \\ 8.0 & 12.5 & 5.9 & 81.6 & 79.0 & 2.6 & 23.4 \\ 5.3 & 9.5 & 1.8 & 88.7 & 85.9 & 2.8 & 21.6 \\ 0.0 & 1.3 & - & 86.8 & 84.0 & 2.8 & 22.6\end{array}$

Näiden lukujen perusteella ja otettaessa laidunrehun osuus samaksi kuin pohjoisissa maanviljelysseuroissa keskimäärin (Taul. 10, p. 38) voidaan laskea eri rehujen vuotuinen käyttö tarkasteltavilla kolmella tuotantotasolla seuraa vaksi:

$\begin{array}{cccccc}\begin{array}{c}\text { Oljy- } \\ \text { kakkuja } \\ \text { Oil cakes }\end{array} & \begin{array}{c}\text { Ohraa } \\ \text { Barley }\end{array} & \begin{array}{c}\text { Heinää } \\ \text { Hay }\end{array} & \begin{array}{c}\text { Odelmaa } \\ \text { AIV- } \\ \text { rehuna } \\ \text { Silage }\end{array} & \begin{array}{c}\text { Laidun- } \\ \text { rehua } \\ \text { Pasture }\end{array} & \begin{array}{c}\text { Yht. } \\ \text { Total }\end{array} \\ & & & & & \\ 243 & 185 & 1274 & 32 & 620 & 2354 \\ 240 & 135 & 1321 & 34 & 625 & 2355 \\ 280 & 220 & 1335 & 32 & 669 & 2563 \\ 162 & 52 & 1208 & 39 & 524 & 1985\end{array}$

Tässä esitettyjä lukuja laskettaessa ei ole otettu huomioon kausiluontoista eroa kesä- ja talvituotannossa. Jos näin tehdään ja käytetään eroavuuden kuvaajina yllä esitettyjä indeksejä, ja edelleen katsotaan laidunkauden tuotos saaduksi ilman väkirehuja, muodostuu halvin riittävä rehuyhdistelmä kolmella tarkastellulla tuotantotasolla seuraavaksi:

$\begin{array}{ccccccc}\text { Oljykakkuja } & \begin{array}{c}\text { Ohraa } \\ \text { Oil cakes }\end{array} & \begin{array}{c}\text { Heinää } \\ \text { Bay }\end{array} & \begin{array}{c}\text { Odelma } \\ \text { AIV-r. } \\ \text { Silage }\end{array} & \begin{array}{c}\text { Laidun } \\ \text { Pasture }\end{array} & \begin{array}{c}\text { Yht. } \\ \text { Total }\end{array} \\ 3200 & 177 & 97 & 1182 & 39 & 814 & 2309 \\ 3600 & 202 & 91 & 1266 & 42 & 877 & 2479 \\ 2800 & 148 & 10 & 1203 & 40 & 757 & 2158\end{array}$

Näiden LP-menetelmällä laskettujen rehumäärien vertailu ennen (p. 360) mainittuihin pohjoisten maanviljelysseurojen ja Suomussalmen tutkimustilojen karjantarkkailutietoihin viittaa siihen, että käytännössä käytetään viljaväkirehuja jopa $2-4$ kertaa enemmän kuin teoreettiset laskelmat osoittavat tarpeelliseksi, kun taas heinää ja öljykakkuja käytetään vähemmän. Mielenkiintoista on edelleen, että vallitsevissa hintasuhteissa nurmenviljelyn alinta tasoa intensiivisemmät tuotantoprosessit jäävät pois kuvasta. Öljykakkujen hinnan ollessa 55 p on edullista käyttää näitä aina n. $10 \%$ :iin saakka koko rehun- 
kulutuksesta. Maidontuotanto perustuisi siten huomattavalta osalta ulkomailta tuotaviin rehuihin, ja nurmenviljelyn tarjoamat mahdollisuudet jäisivät osaksi käyttämättä.

Se että öljykakkujen käyttö viljaväkirehuihin verrattuina - joita viimeksi mainittujakin tuodaan alueelle runsaasti muualta - on ollut suhteellisesti vähäisempää, on saattanut johtua siitä, että ensiksi mainittuja ei kuluneina vuosina aina ole ollut saatavissa.

Silmälläpitäen sitä mahdollisuutta, että öljykakkujen saanti esim. talouspoliittisista syistä tultaisiin jatkuvasti rajoittamaan, saattaisi olla paikallaan selvittää, millaisia vaihtoehtoja heinänurmen viljelyintensiteetissä edellyttäisi vaatimus väkirehun antamisesta seoksena, jossa öljyväkirehun ja ohran (tai kauran) ry-määrän suhde olisi oletettu kiinteäksi (esim. 1: 3, vastaten tarkkailukarjoissa vallitsevaa keskimääräistä suhdetta).

Ensimmäisen LP-kokeilun johdosta syntyi myöskin epäily, että käyttämämme keskiarvot päivittäisestä maidontuotannosta ehkä eivät parhaalla tavalla anna perustaa ruokinnan vuotuista kokoonpanoa koskevalle laskelmalle. Edelleen saattoi ajatella, että laskelmissa säilörehuille käytetty verraten epäedullinen täyttävyysluku on johtanut tulokseen, jossa intensiivinen nurmenviljely ei ole päässyt oikeuksiinsa.

Tämän tutkimuksen suunnitelman lopullisesti muotoutuessa oli mahdollisuus käyttää hyväksi MäkElän (1956, p. 106) sekä HypPölän ja HASUSEN (1970) uusia tutkimustuloksia, joista saatiin työn aikana eräitä ennakkotietoja. Näiden tutkimusten mukaan päästään kuiva-ainemaksimia määritettäessä parempaan tulokseen kertomalla väkevien rehujen (väkirehut ja juurikasvit) kuiva-ainearvot kertoimilla 0.5 ja 0.6 . Näin lasketulle m u u n e t u 11 e kuivaaineelle on kokemusperäisesti määrätty maksimi, joka $\mathbf{5 0 0}$ kilon painoiselle lypsylehmälle on $11.5 \mathrm{~kg} .100 \mathrm{~kg}$ :n muutos elopainossa muttaa kuiva-ainenormia 1.6 kg:lla samaan suuntaan (HyPPölä ja HASUnen 1970, p. 47). Maitomäärän muutos $18 \mathrm{~kg}$ :sta $10 \mathrm{~kg}$ :lla vaikuttaa samalla tavalla $0.4 \mathrm{~kg}$ :n muutoksen. Seuraavissa laskelmissa on n. $400 \mathrm{~kg}: \mathrm{n}$ elopainoiselle lehmälle asetettu muunnetun kuiva-aineen maksimi $10 \mathrm{~kg}$.

Säilörehun täyttävyyden kohdalta on uusissa laskelmissa sovellettu arvoa 1.4. Seuraavassa koelaskelmassa, joka on suoritettu Helsingin yliopiston laskentakeskuksen tietokoneella, pyrittiin selvittämään, miten tämän täyttävyysluvun käyttäminen muuttaa edullisimman ruokintasuunnitelman rakennetta.

Laskelmia edelleen kehitettäessä katsottiin tarpeelliseksi myöskin asettaa ennakolta alaraja heinäksi kuivatun sadon käytölle ruokinnassa. Pelkästään säilörehun tuotantoon ei lypsykarjan tuotantoa voida tarkoituksenmukaisesti rakentaa. Eräissä kotimaisissa kokeissa (VIRTANEN 1943, p. 288-297) on tosin verraten korkeisiin maidontuotoksiin runsaalla AIV-rehun käytöllä päästy, vaikka kuivan heinän määrä on supistettu $1-2 \mathrm{~kg}$ :aan päivässä, mutta heinien täydellistä korvaamista ruohosta valmistetulla säilörehulla ei kustannussyistäkään liene koskaan suositeltu. Eräissä vuoden 1966 Kansainvälisessä nurmiviljelykongressissa pidetyissä esitelmissä todettiin kuivan heinän käytön säilörehun rinnalla noin puoleen rehuyksikkömäärästä olevan tuotannon kannalta edullista (Wellman 1966, p. 223, Foot ja Line 1966, p. $238-241$, Nordfeldt 1966, p. 245). Aikaisin korjattu heinä näyttää säilörehua paremmin yksinään 
soveltuvan väkirehun täydentäjäksi ainakin korkeatuottoisilla lehmillä; toisaalta näyttää kummankin rehun kulutus vapaasti annettaessa riippuvan väkirehuannoksen suuruudesta.

Timoteiheinän käytön vähimmäismäärä on alempana esitetyissä laskelmissa asetettu $20 \%$ :ksi koko rehuyksikkömäärästä.

\section{Kunkausittaisiin keskilypsyihin perustuva ruokintasuunnitelma}

Edelläesitetyt alustavat laskelmat on suoritettu jakamalla lypsykausi vain kahteen osaan, joiden keskimääräisten tuotantomäärien mukaan suunnitelma on tehty. Tarkempien tulosten saamiseksi on LP-menetelmällä laskettu optimaalinen ruokintasuunnitelma lypsykauden eri kuukausille.

Käyttäen vertailukohteena BRUUNin lypsykauden maidontuotantokäyriä koskevaa tutkimusta (1928) on kolmea tarkasteltavaa tuotannontasoa varten käsivaraisesti piirretty suhteellisesti edullista ja suhteellisesti epäedullista maitotuotoksen jakaantumista koskevat käyrät. Näistä on kuukausittaiset keskipäivätuotannot saatu interpoloinnilla seuraavan asetelman mukaisiksi.

Kuukauden järjestysluku
poikimisesta
Ordin. number
of the month

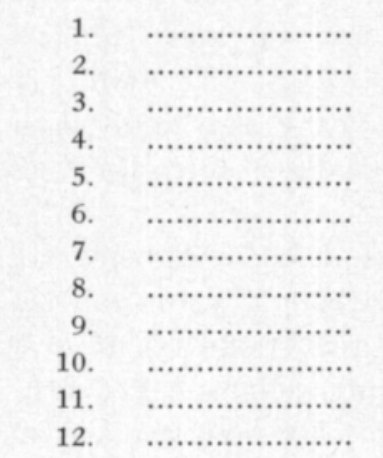

$5 \mathbf{k k}-$ month

Päivittäiset keskituotokset lypsykauden kuukausina Monthly averages of milk yield per day

\begin{tabular}{|c|c|c|c|c|c|}
\hline \multicolumn{2}{|c|}{$3600 \mathrm{~kg} / \mathrm{v}$} & \multicolumn{2}{|c|}{$3200 \mathrm{~kg} / \mathrm{v}$} & \multicolumn{2}{|c|}{$2800 \mathrm{~kg} / \mathrm{v}$} \\
\hline & dontuotan & käyrän & lessa $-w$ & lact. cul & \\
\hline $\begin{array}{l}\text { edull. } \\
\text { favour. }\end{array}$ & $\begin{array}{l}\text { epäedull. } \\
\text { unfavour. }\end{array}$ & $\begin{array}{l}\text { edull. } \\
\text { favour. }\end{array}$ & $\begin{array}{l}\text { epäedull. } \\
\text { unfavour. }\end{array}$ & $\begin{array}{l}\text { edull. } \\
\text { favoru. }\end{array}$ & $\begin{array}{l}\text { epảedull. } \\
\text { unfavour. }\end{array}$ \\
\hline 12.9 & 12.0 & 9.9 & 12.0 & 11.0 & 12.0 \\
\hline 15.9 & 17.6 & 12.9 & 18.2 & 13.3 & 17.7 \\
\hline 15.4 & 17.4 & 13.0 & 18.0 & 13.1 & 17.6 \\
\hline 13.8 & 15.6 & 12.9 & 15.8 & 12.0 & 15.3 \\
\hline 12.3 & 13.6 & 12.3 & 12.0 & 10.6 & 10.5 \\
\hline 11.5 & 12.0 & 11.5 & 9.5 & 9.2 & 7.5 \\
\hline 10.6 & 10.0 & 10.5 & 6.8 & 7.6 & 5.1 \\
\hline 9.8 & 8.6 & 9.2 & 6.3 & 6.3 & 3.6 \\
\hline 8.6 & 7.2 & 7.4 & 4.6 & 4.7 & 2.6 \\
\hline 7.0 & 5.3 & 5.2 & 3.2 & 3.3 & 1.4 \\
\hline 3.5 & 2.0 & 1.9 & 0.3 & 1.4 & 0.1 \\
\hline 0 & 0 & 0 & 0 & 0 & 0 \\
\hline 58 & 63 & 57 & 71 & 57 & 78 \\
\hline
\end{tabular}

Rehuntarve on kutakin kuukautta varten arvioitu siten, että elatusrehuksi päivässä on katsottu tarvittavan 3.1 rehuyksikköä ja 266 g sulavaa raakavalkuaista, tuotantorehuksi 0.38 ry ja 58.5 g srv maitokiloa kohden, minkä lisäksi sikiön kasvua varten on katsottu tarvittavan kolmena viimeisenä tiineyskauden kuukautena $0.60,1.43$ ja 1.73 ry sekä 96,226 ja 276 g srv vastaavasti päivittäin. Ruokintasuunnitelmat on tehty tätä silmällä pitäen, samalla noudattaen kuivaainesisällön kohdalta ylempänä selostettua uutta periaatetta.

Jotta saavutettaisiin yhdenmukaisuus aikaisempien laskelmien kanssa on 
laidunkausi lypsykauden kuukausien järjestysluvun puolesta sijoitettu siten, että p. 392 mainitut suhteet laidunkauden ja sisäruokintakauden tuotosten välillä toteutuvat. Laidunkauden on edellytetty kestävän 4 kuukautta, ja laskettaessa eri rehujen osuutta on lypsykauden tietyt kuukaudet toisinaan jouduttu jakamaan laidun- ja sisäruokintakauden kesken. Laidunkautena ei lypsykauden asianomaisen kuukauden kohdalla edellytettyjä rehuannoksia ole ajateltu käytetyiksi, vaan korvatuiksi vastaavalla ry-määrällä laidunrehua. Kun laidunrehun srv.pitoisuudeksi on edellytetty $163 \mathrm{~g} / \mathrm{ry}$ ja täyttävyydeksi 1.3 , on vain harvoissa tapauksissa osoittautunut tarpeelliseksi korvata osa rehuyksiköistä viljalla.

\section{Tietokoneella suoritetut koelaskelmat}

Edellisen nojalla on lypsykarjantuotantoa varten edullisin suunnitelma otaksuttu voitavan laatia seuraavalla tavalla. Perustuotannoksi on valittu alustavien laskelmien mukaan alhaisimmin muttuvin kustannuksin tapahtuva, $\mathrm{A}_{1}$-intensiteettiastetta vastaava heinäntuotanto, jonka odelmasadosta pieni osa $(3.2 \%)$ korjataan AIV-rehuksi, loppu laitumena. Kun paikkakunnalla mahdollisesti tuotettavalle ohralle halutaan turvata menekkiä, sisällytetään viljelysuunnitelmaan AIV-nurmia, joiden runsaasti sulavaa raakaproteinia sisältävät sadot korjataan AIV-rehuksi, kuitenkin olosuhteiden mukaan myöskin laiduntamista käyttäen. Edullisin suhde heinänurmien $\left(\mathrm{A}_{1}\right)$ ja $\mathrm{AIV}$-nurmien eri intensiteettiasteiden (kysymykseen voivat tulla vain $C_{2}$ tai $D_{2}$ ) välillä valitaan LP-menetelmällä, jossa lisäehdoksi (varmuuden vuoksi) asetetaan, että kuivaa heinää sisältyy sisäruokintaan vähintään $20 \%$ ry-määrästä. Väkirehuseokseen sisältyy, kuten edellisissä esimerkeissä, 1/4 öljykakkuseosta. Laidunkauden maidontuotos on edelläkuvatulla tavalla edellytetty sisäruokintakauden tuotosta korkeammaksi, ja laidunkauden mahdollinen väkirehuntarve on laskettu samoilla perusteilla kuin sisäruokintakaudenkin.

Huomioonottaen mainitun heinän vähimmäismäärän vaikutuksen rehuyksikön ravintosisältöön voidaan simplex-menetelmässä soveltaa seuraavanlaisia epäyhtälöitä (esimerkkinä $3600 \mathrm{~kg}$ vuosituotantoisen epäedullisen tuotantokäyrän omaavan lehmän 2. lypsykuukauden päivätuotantoa $(17.6 \mathrm{~kg})$ vastaava ruokinta, tekniikka I. $^{1}$ )

Valkuaisrajoitus:

(1) $0.14125 \mathrm{X}_{1}+0.0750 \mathrm{X}_{2}+0.0913 \mathrm{X}_{3}+0.1109 \mathrm{X}_{4}+0.1284 \mathrm{X}_{5}+0.1520 \mathrm{X}_{6}+0.1770 \mathrm{X}_{7}$ $+0.2330 \mathrm{X}_{8} \geqq 1296$

Täyttävyysrajoitus:

(2) $0.450 \mathrm{X}_{1}+0.450 \mathrm{X}_{2}+1.880 \mathrm{X}_{3}+1.842 \mathrm{X}_{4}+1.786 \mathrm{X}_{5}+1.420 \mathrm{X}_{6}+1.420 \mathrm{X}_{7}$ $+1.420 \mathrm{X}_{8} \leqq 10$

1) Myöhemmin suoritettujen tarkistusten vuoksi LP-laskelmissa käytetyt kertoimet eivät kaikissa tapauksissa täydellisesti täsmää aikaisemmin esitettyjen kanssa. Esiintyvät muutaman desimaalin erot eivät luotettavuusrajojen sisällä vaikuta ruokintasuunnitelmiin. 
Määräyhtälö:

(4) $\mathrm{X}_{1}+\mathrm{X}_{2}+\mathrm{X}_{3}+\mathrm{X}_{4}+\mathrm{X}_{5}+\mathrm{X}_{6}+\mathrm{X}_{7}+\mathrm{X}_{8}=9.79$

Minimointi

(5) $37.7 \mathrm{X}_{1}+32 \mathrm{X}_{2}+14.9 \mathrm{X}_{3}+17.0 \mathrm{X}_{4}+17.4 \mathrm{X}_{5}+21.6 \mathrm{X}_{6}+21.9 \mathrm{X}_{7}+31.8 \mathrm{X}_{8}=$ Min.

Simplex-ratkaisu on tässä tapauksessa johtanut päiväannokseen, johon sisältyy 0.96 ry öljyväkirehua, 4.00 ry ohraa, 1.96 ry $\mathrm{TiA}_{1}$ tuotantoprosessin satoa (4.7 kg heinää ja n. $0.4 \mathrm{~kg}$ säilörehua) sekä 2.87 ry $\mathrm{TiD}_{2}: \mathrm{n}$ satoa $(\mathrm{n} .18 \mathrm{~kg}$ säilörehua). Rehuannoksen kustannushinnaksi muodostuu 2:73, s.o. 27.8 p/ry. Kuukautta kohden rehunkäyttö on saatu kertomalla 30:1la, kun taas vuotuinen kulutus muodostuu kuukausimäärien summasta.

\section{Koelaskelma B. Säilörehun täyttävyysluvun vaikutus ruokintasuunnitelmaan}

Kuukausikeskiarvojen perusteella tehtiin aluksi koelaskelma, jossa 3600 kg:n tuotannon ja epäedullisen maidontuotantokäyrän edellytyksillä laskettiin eri tuotantoprosesseissa tuotettavien rehujen edullisin jakautuminen vaihtoehdoissa, joissa säilörehun täyttävyys on 1.60 tai 1.42. Tulokset esitetään seuraavassa asetelmassa. Eri tuotantoprosessien kuivaheinä- ja säilörehumäärät on siinä yhdistetty; kaikkien tuotantoprosessien luvut on sitäpaitsi koottu taulukkoon 12.

\begin{tabular}{|c|c|c|c|c|c|c|c|c|}
\hline \multirow[b]{2}{*}{$\begin{array}{c}\text { Jos säilörehun } \\
\text { täyttävyys on } \\
\text { If DM content } \\
\text { of sicage is }\end{array}$} & \multicolumn{7}{|c|}{$\begin{array}{c}\text { Edullisin rehujakautuma, ry } \\
\text { Optimum combination of feeds, f.u. }\end{array}$} & \multirow{2}{*}{$\begin{array}{l}\text { Kustannus } \\
\text { : Cost } \\
\text { ry kohden } \\
\text { per f.u. }\end{array}$} \\
\hline & $\begin{array}{l}\text { Tekn. } \\
\text { Techn. }\end{array}$ & $\begin{array}{l}\text { Öljy- } \\
\text { väki- } \\
\text { rehu } \\
\text { Oil cakes }\end{array}$ & $\begin{array}{l}\text { Ohra } \\
\text { Barley }\end{array}$ & $\begin{array}{c}\text { Timotei- } \\
\text { heinä } \\
\text { Hay }\end{array}$ & $\begin{array}{l}\text { AIV- } \\
\text { säilör. } \\
\text { Silage }\end{array}$ & $\begin{array}{l}\text { Laidun } \\
\text { Pasture }\end{array}$ & $\begin{array}{l}\text { Yht. } \\
\text { Total }\end{array}$ & \\
\hline 60 . & I & 78 & 417 & 728 & 529 & 858 & 2611 & 19.4 \\
\hline & II & 78 & 405 & 644 & 627 & 858 & 2612 & 17.7 \\
\hline 20 & I & 64 & 360 & 758 & 573 & 858 & 2615 & 18.7 \\
\hline & II & 64 & 335 & 677 & 677 & 858 & 2611 & 17.1 \\
\hline
\end{tabular}

Verrattaessa vaihtoehtoja todetaan, että molempien nurmenviljelytekniikkojen olosuhteissa alemman täyttävyysluvun soveltaminen tekee mahdolliseksi väkirehun käytön supistamisen 15-17\%:lla, samalla kun kustannukset rehuyksikköä kohden alenevat $0.6-0.7$ pennillä eli n. $5 \%$. Traktoritekniikassa säilö-

1) Kuivaheinäminimi olisi oikeammin pitänyt esittää muodossa

$0.968 \mathrm{X}_{3}+0.838 \mathrm{X}_{4}+0.789 \mathrm{X}_{5} \geqq 0.20 \times 9.79$,

koska tuotantoprosessit TiA $\mathrm{A}_{2} \mathrm{~A}_{1}$ ja $\mathrm{A}_{3} \mathrm{~B}_{2}$ sisältävät myös säilörehua. Kun TiA $\mathrm{A}_{1}$ alhaisen kustannushintansa vuoksi useimmiten työntää nämä toiset vaihtoehdot pois, tarkempi rajoitus tuskin kuitenkaan olisi muuttanut tuloksia. 
rehujen käyttöä kannattaa näillä edellytyksillä lisätä enemmän kuin hevostekniikassa.

Sisäruokintakauden rehujen keskimääräinen raakavalkuaispitoisuus olisi tekn. I n olosuhteissa $125 \mathrm{~g} / \mathrm{ry}$ ja täyttävyys olisi edellisen vaihtoehdon mukaan 1.56 ja jälkimmäisen mukaan (jolloin väkirehun osalta on sovellettu muunnetun kuiva-aineen periaatetta, vrt. edellä p. 395) (Hyppölä \& HASUneN 1970). 1.39. Edellisen laskutavan mukaan on päästy jotenkin samaan keskiarvoon kuin tutkimusalueen tarkkailukarjoissa (vrt. p. 360), myös raakavalkuaispitoisuuden ollessa suunnilleen samoilla lukemilla.

Tietyillä epäilyillä on kuitenkin suhtauduttava laidunrehuyksiköiden määrään. Kysymys on ennenkaikkea siitä, voidaanko päivätuotantoa, joka laidunkauden ensimmäisenä kuukautena olisi 14.6, viimeisenä $9.7 \mathrm{~kg}$ ja keskimäärin koko jaksona $11.2 \mathrm{~kg}$, ylläpitää miltei kokonaan ilman lisärehua. Pelkästään normien ja edellä asetettujen täyttävyyslukuvaatimusten perusteella on laskettavissa, että ensimmäisenä laidukauden kuukautena 44 ry laidunrehusta olisi korvattava ohralla.

\section{Koelaskelma C. Maidon tuotantokäyrän muodon ja laidunkauden ajankohdan vai- kutus ruokintasuunnitelmaan}

"Edulliseksi» on tässä tutkimuksessa nimitetty maidontuotantokäyrää, jossa päivätuotannot eivät nouse kovin korkealle, mutta pysyvät suhteellisesti tasaisina lypsykauden loppukuukausille saakka (vrt. p. 391). Voidaan odottaa, että tällaisissa oloissa selviydytään pienemmällä väkirehumäärällä ja ry:ä kohden alemmilla tuotantokustannuksilla kuin »epäedullisen» käyrän olosuhteissa. Koelaskelman C tarkoitus on valaista asiaa vertaamalla $3200 \mathrm{~kg}: \mathrm{n}$ vuotuisen maidontuotannon ruokintasuunnitelmia tapauksissa, joista toisessa $\mathbf{5 7} \%$ ja toisessa $71 \%$ maidontuotoksesta on saatu 5 ensimmäisen lypsykuukauden kuluessa.

Laidunkauden sijoittumisella lypsykauden kuukausille on myöskin vaikutuksensa sisäruokintakauden rehukoostumukseen. Selvittääksemme, miten poikkeaminen tuotantosuunnitelmaa varten hyväksytystä pariaatteesta saattaisi vaikuttaa ruokintasuunnitelmaan ja kustannuksiin, on koelaskelman C molempien lypsykäyrävaihtoehtojen ruokintasuunnitelmat tehty myöskin "myöhäisen» laidunkauden edellytyksellä. Tällöin laidunkausi on sijoitettu niin, että sen keskimääräinen päivätuotanto vastaa vuoden keskimääräistä päivätuotantoa. Laidunkaudet sijoittuvat tässä tapauksessa n. 2 kuukautta myöhäisemmiksi kuin tämän tutkimuksen mnormaalitapauksessa". Keskimääräiset poikimisajat sattuvat tässä "normaalitapauksessa" maaliskuun, myöhäisen laidunkauden tapauksessa helmikuun alkuun. Laidunkausi on tässä koelaskelmassa kuten edellisessäkin asetettu 110 päivän pituiseksi.

Valtion Tietokonekeskuksen koneella suoritetun LP-laskelman tulokset nähdään, paitsi Taulukossa 13 tuotantoprosessittain esitettynä, myös seuraavassa asetelmassa, josta nähdään varsinainen rehujakautuma. 
Maidontuot. käyrä,

laidunkauden

sijoittuminen ${ }^{1}$ )

Lactation curve,

pasture period $\mathbf{1}$ )

$3200 \mathrm{~kg} \mathrm{e})$

(a)

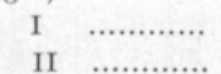

$-$

251

214

Edullisin rehujakautuma

Optimum combination of feeds

$\begin{array}{ccccccc}\text { Öljykakut } & \text { Ohra } & \text { Timotei- } & \text { AIV- } & \text { Laidun } & \text { Yht. ry kohden } \\ \text { Oil cakes Barley } & \text { heinä } & \text { säilör. } & \text { Pasture } & \text { Total } & \text { per fu } \\ & & \text { Hay } & \text { Silage }\end{array}$

$3200 \mathrm{~kg} \mathrm{e})$

(b)

I $\ldots \ldots \ldots \ldots \ldots \ldots$

II $\ldots . . . . . . .1 \quad 322$

355
322

782

640

616

794

815

817

2465

2465

17.3

15.5

\section{8}

536

718

902

707

2458

18.5

$3200 \mathrm{~kg}$ (ee)

(a)

I $\quad \cdots . . . \cdots \cdots$

$60 \quad 313$

$60 \quad 303$

881

757

389

525

444

430

764

661

505

623

707

2467

16.6

$\begin{array}{lll}820 & 2463 & 18.6\end{array}$

$\begin{array}{lll}823 & 2468 & 16.7\end{array}$

(b)

$\begin{array}{llr}\text { I } & \cdots \cdots \cdots \cdots \cdots & 75 \\ \text { II } & \cdots \cdots \cdots \cdots \cdots & 75\end{array}$

Asetelmasta selviää, että edullisen tuotantokäyrän tapauksessa saavutetaan säästöä väkirehussa ja yli pennin säästö ry:ä kohden kustannuksissa, ja aikaisempi laidunkausi aiheuttaa miltei samalla tavalla säästöä Mainittakoon kuitenkin, että esim. BRUNNFÄLTin (1952) tutkimukset Ruotsissa viittaavat siihen, että syksyllä poikineet lehmät saattavat osoittautua edullisemmiksi kuin kevätpoikivat sen vuoksi, että laiduntamisen johdosta tuotantomäärät lypsykauden loppupuolella kohoavat ja nostavat myös vuosituotannon määriä.

\section{Uudistilan tuotantosuunnitelmassa sovellettavat luvut}

Lopullista tuotantosuunnitelmaa laadittaessa oli pyrkimyksenä käyttää yhdistelyä, joka johtaisi optimaaliseen tulokseen. Kun eläinten tuotantokyky muodostaa rajoituksen, josta ei etukäteen voida olla selvillä, valittiin LPlaskelmassa vaihtoehdoiksi kolme maidontuotannon tasoa, 2800, 3200 ja 3600 kg. Maidontuotantokäyrän osalta, joka sekin on osaksi perinnöllisyystekijöistä riippuva, olisi ollut paikallaan soveltaa sekä edullisia että epäedullisia vaihtoehtoja. Lopullisissa laskelmissa ei kuitenkaan näin ole tehty, vaan kultakin intensiteettitasolta on otettu yksi vaihtoehto. $3600 \mathrm{~kg}: \mathrm{n}$ vuosituotannon osalța on sovellettu »epäedullista», $3200 \mathrm{~kg}: \mathrm{n}$ »edullista" ja $2800 \mathrm{~kg}: \mathrm{n}$ osalta »edullista" lypsykäyrää.

LP-laskelmissa sovellettujen ruokintasuunnitelmien rakenne selviää taulukosta sekä alla olevasta asetelmasta. Asetelmaan on otettu myöskin Suomussalmen tutkimusalueen tarkkailukarjojen rehunkäyttöjakautuma vv. 1959-63 ja kustannus ry:ä kohden edellyttäen käytetyksi samoja hintoja kuin LP-laskelmissa.

1) $\mathrm{e}=$ edullinen lypsykäyrä, favourable lactation curve

ee = epäedullinen , unfavourable ,

$\mathrm{a}=$ aikainen laidunkausi, early pasture period

$\mathrm{b}=$ kaksi kuukautta myöhäisempi laidunkausi, 2 months later pasture period 
Tuotantotaso

Production level
Edullisin rehujakautuma, ry lehmää kohden

Optimum combination of feeds, f.u. per cow
Kustannus Cost

$\begin{array}{cccclcc}\text { Öljykakut Ohra } & \begin{array}{c}\text { Timotei- } \\ \text { heinä }\end{array} & \begin{array}{c}\text { AIV- } \\ \text { säilör. }\end{array} & \text { Laidun } & \text { Yht. } & \text { p/ry. } \\ \text { Oil cakes Barley } & \text { Hay } & \text { Silage } & \text { Pasture } & \text { Total } & \text { plf.u. }\end{array}$

$3600 \mathrm{~kg}(\mathrm{ee})$

$\begin{array}{lrlllllll}\text { I } & \ldots \ldots \ldots \ldots \ldots \ldots . . & 72 & 420 & 734 & 554 & 849 & 2629 & 18.9 \\ \text { II } & \ldots \ldots \ldots \ldots \ldots . . . & 72 & 410 & 670 & 632 & 849 & 2633 & 17.5\end{array}$

$3200 \mathrm{~kg}(\mathrm{e})$

$\begin{array}{lllllllll}\text { I } & \ldots \ldots \ldots \ldots \ldots & 23 & 365 & 634 & 643 & 801 & 2466 & 18.6\end{array}$

$\begin{array}{lllllllll}\text { II } & \ldots \ldots \ldots \ldots \ldots . & 23 & 353 & 543 & 745 & 801 & 2465 & 16.9\end{array}$

$2800 \mathrm{~kg}(\mathrm{e})$

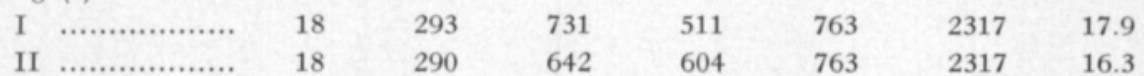

Suomussalmen tarkkailukarjat - Suomussalmi milk Rec. herds

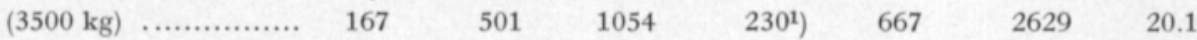

1) Tämä erä koostuu erilaisista rehuista - not only silage 


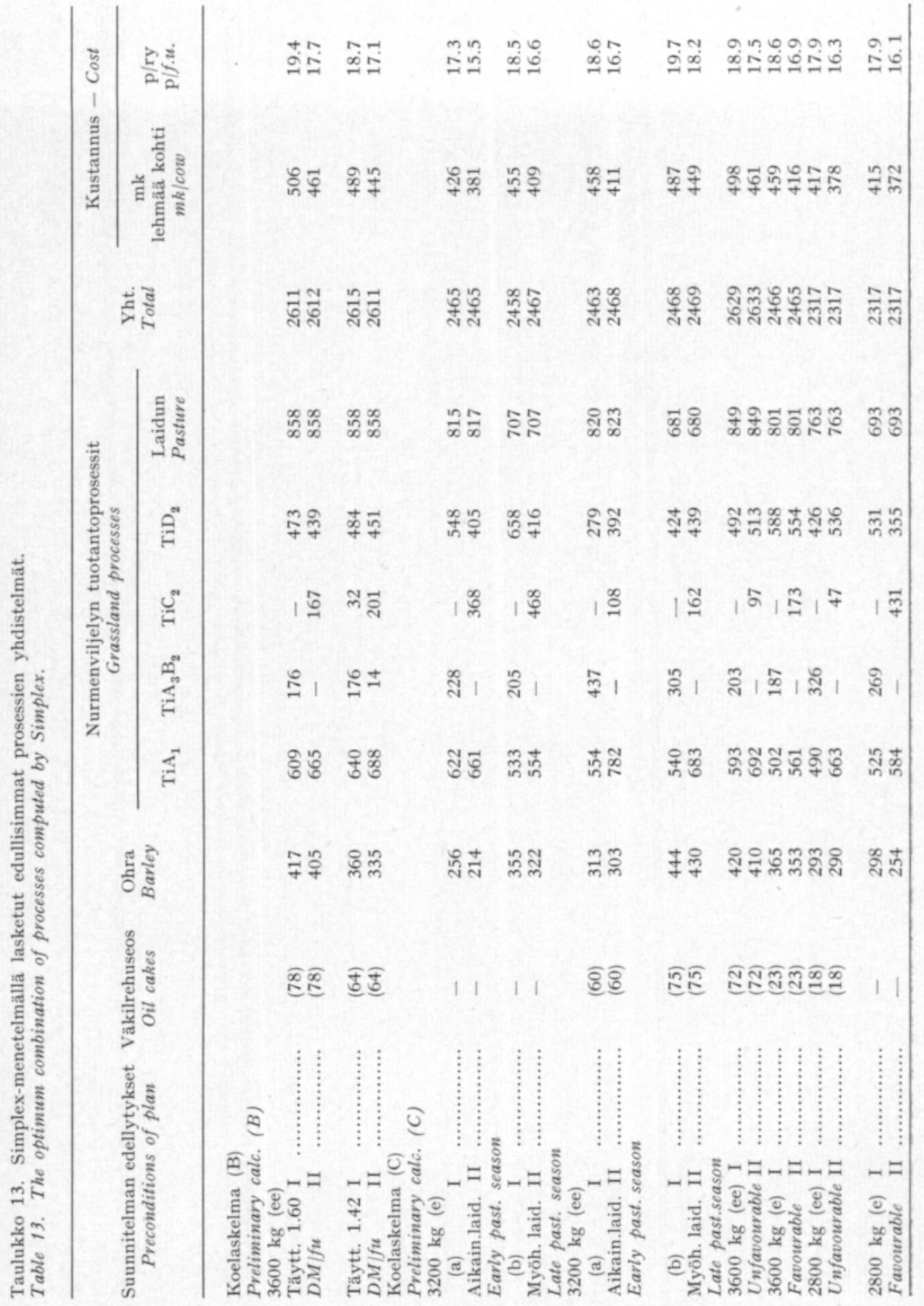


LP-menetelmällä lasketut ruokintasuunnitelmat ovat johtaneet rehujakautumaan, jossa ulkomailta tuotavien öljyväkirehujen käyttö on supistunut alle puoleen siitä mitä se on tarkkailukarjojen rehunkäyttökirjanpidon mukaan. Ruokinta perustuu korkeinta tuotantovaihtoehtoa tarkoittavassa tapauksessa yli $80 \%$ :sesti viljelyvarmaan nurmiviljelyyn, kun se tarkkailukarjoissa on perustunut siihen n. $70-75 \%$ :sesti. Muuttuvan kustannuksen pienehkö supistuminen on myös havaittavissa.

\section{Lypsykarjatalouden katetuottolaskelmat}

Katetuoton selvittämiseksi määrätään ensiksikin kokonaistuotto, joka saadaan kertomalla maitotuotos maidon hinnalla ja lisäämällä tuloon vasikan sekä lannan arvo. Maidon arvo lasketaan, kuten edellä (p. 380) on esitetty, kolmen vaihtoehtoisen hinnan $-: 36$ (a), $-: 25$ (b) ja -:70 (c) perusteella. Vasikan arvo on kaikissa tapauksissa edellytetty $\mathbf{5 0}$ markaksi ja lannan arvo on laskettu lähinnä sen sisältämien kasvinravinteiden arvon perusteella 7 markaksi tonnilta eli 42:- markaksi eläintä kohden.

Kuivikkeiden arvo esiintyy katetuoton supistuksena. On arvioitu käytettävän $1200 \mathrm{~kg}$ olkia, joiden hinnaksi on laskettu $3 \mathrm{p} / \mathrm{kg}$.

Eräät muuttuvien kustannusten erät, kuten kalustokustannukset, polttopuut ja sähkö, eläinpääoman korko sekä erinäiset rahamenot on arvioitu lähinnä maatalouden kannattavuustutkimuksen vastaavien lukujen perusteella. Ns. osuutta yleiskustannuksiin ei katetuottolaskelmassa ole otettu mukaan. Sensijaan on lypsylehmän uusimiskustannus katsottu sellaisenaan vähennyseriin kuuluvaksi.

Uusimiskustannusta varten on arvioitu hiehon kasvatukseen poikimakuntoiseksi kuluva rehumäärä, joka on hinnoiteltu tässä tutkimuksessa sovellettujen muuttuvien kustannusten mukaan. Ruokintakustannus koostuu maidon hinnasta riippuen kahden vaihtoehdon mukaan seuraavasti:

Hiehon ruokintakustannus - Feeding of the heifer

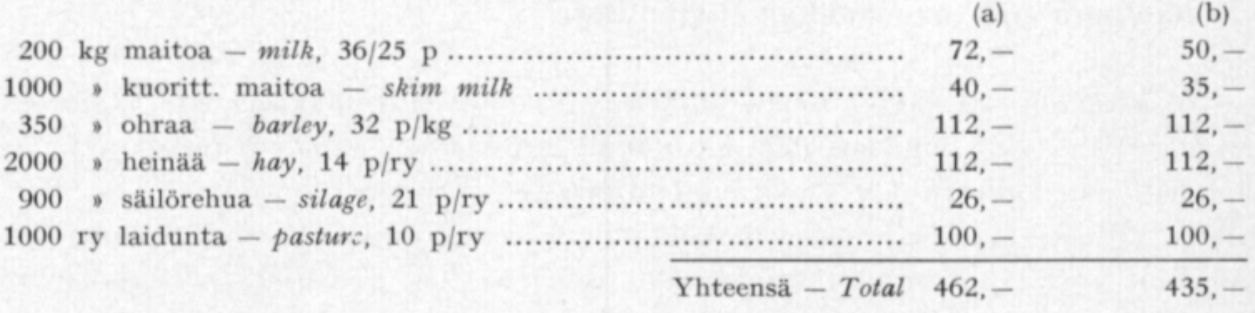

Hiehon kasvattamiseen tarvittava työmäärä on 130 t, mikä hinnoitellaan 2 markan mukaan tunnilta. Eläinpääoman korko lasketaan 2 vuoden ajalta puolelle kasvatuskustannuksista $6 \%$ :n mukaan. Kun vasikan hinta otetaan mukaan kasvatuskustannukset ovat kaikkiaan a) tapauksessa 818 : - ja b) tapauksessa $790:-$.

Jos vuotuinen karsinta lasketaan $15 \%$ :ksi ja teuraslehmästä saadaan 390 $\times 0.425=167 \mathrm{~kg}$ lihaa jonka arvo $2: 52$ mukaan on $421:-$, päädytään tapauk- 
sessa a) 60 markan, tapauksessa b) $\mathbf{5 5}$ markan uudistuskustannukseen lypsylehmää kohden vuodessa.

Vähennyksenä katetuottoon tulee tässä laskelmassa edelleen ostettujen öljyväkirehujen arvo. Tarvittavien rehuyksiköiden luku selviää aikaisemmista ruokintasuunnitelmista, jotka on tehty erikseen tekn. I. ja tekn. II:n olosuhteita varten. Hintana käytetään tässäkin 55 p/ry. Edelleen vähennetään kivennäisrehujen arvo, joka on otettu maatalouden kannattavuustutkimuksesta.

Maidontuotannon katetuotto, jonka on peitettävä myös rehunviljelynmuuttuvat kustannukset, muodostuu näillä edellytyksillä eri tapauksissa seuraavaksi:

\begin{tabular}{|c|c|c|c|c|c|c|}
\hline Vuosituotanto - Production & & & & & & \\
\hline Maidon hinta ${ }^{1}$ ) - Milk price $^{1}$ ) & (a) & (b) & (a) & (b) & (a) & (b) \\
\hline Tuotto - Return & & & & & & \\
\hline Maito - Milk .................... & 1296 & 900 & 1152 & 800 & 1008 & 700 \\
\hline Vasikka - Calf ...................... & 50 & 50 & 50 & 50 & 50 & 50 \\
\hline 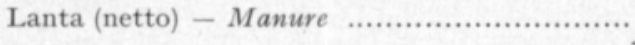 & 42 & 42 & 42 & 42 & 42 & 42 \\
\hline & 1388 & 922 & 1244 & 892 & 1100 & 792 \\
\hline Muuttuvat kust. - Variable costs & & & & & & \\
\hline Öljykakut - Oil cakes ........................... & 40 & 40 & 13 & 13 & 10 & 10 \\
\hline Kivennäisaineet - Minerals ................... & 13 & 13 & 13 & 13 & 13 & 13 \\
\hline Viljan jauhatus - Grain grinding ............. & 8 & 8 & 7 & 7 & 6 & 6 \\
\hline Kuivike - Litter ................................ & 36 & 36 & 36 & 36 & 36 & 36 \\
\hline Polttopuut, sähkö - Fuel, electr............... & 14 & 14 & 14 & 14 & 14 & 14 \\
\hline Kalusto - Utensils ................................. & 13 & 13 & 13 & 13 & 13 & 13 \\
\hline Erill. rahamenot - Cash paym. ............... & 30 & 30 & 30 & 30 & 30 & 30 \\
\hline Eläinp. korko - Interest of livestock capit. .... & 26 & 26 & 26 & 26 & 26 & 26 \\
\hline Uudistus - Depreciation .......................... & 60 & 55 & 60 & 55 & 60 & 55 \\
\hline Muuttuvat kust. - Variable costs .............. & 240 & 235 & 212 & 207 & 208 & 203 \\
\hline Katetuotto - Gross margin ..................... & 1148 & 757 & 1032 & 685 & 892 & 589 \\
\hline
\end{tabular}

Maidon hinnan ollessa -:70 eli hintatilanteessa (c) katetuotot ovat vaihto-

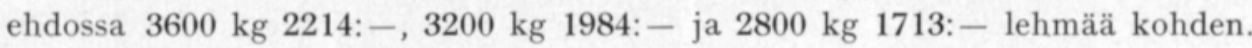

\section{Tuotantoprosessit naudanlihan tuotannossa}

Vasikoiden kasvattamisesta lihaeläimiksi oli tutkimuksen suorittamisen ajankohtana vain niukasti koetoimintaan perustuvaa tietoa. Niinpä esim. taloudellisesti edullisimman ruokinnan suunnittelua varten oli vaikea löytää normeja, erityisesti rehuannoksen kokoonpanon osalta. Oppikirjoissa yleensä suositeltiin verraten runsasta täysimaidon käyttöä kasvatettaville vasikoille, ja kuorittu maito kuului jotenkin välttämättömästi kasvatukseen aina 6 kuukauden ikään.

Tutkimuksen kasvatusvaihtoehtoja suunniteltaessa käytettiin hyväksi mm. JÄÄSKELÄISEN (1936) tutkimustuloksia ayrshirekarjan hiehojen rehunkäytöstä ja elopainon kehityksestä kasvatuskaudelta, joka ulottui 30 kuukauden ikään. Rehunkäyttö oli laskettu sisäruokintakauden rehuina eri-ikäisistä hiehoryhmistä

1) Hintatilanne (a),$- 36 \mathrm{mk} / \mathrm{kg}$, (b),$- 25 \mathrm{mk} / \mathrm{kg}$. 
tehtyjen havaintojen perusteella. Toisissa, Salmisen (1964) Pohjois-Savon koeasemalla suorittamissa kokeissa maaliskuun alussa syntyneitä ayrshiremulleja kasvatettiin mahdollisimman pienellä väkirehun ja runsaalla heinän ja laidunrehun käytöllä kahden laidunkauden yli 19 kuukauden ikään. Painohavainnot tehtiin siinä yhteydessä mm. laidunkausien alkamis- ja päättymispäivinä, jolloin päivittäinen lisäkasvu todettiin 1. laidunkautena 687 ja 2. laidunkautena $919 \mathrm{~g}: \mathrm{ksi}$, välillä olevan väkirehuttoman sisäruokintakauden kasvun ollessa $274 \mathrm{~g} / \mathrm{pv}$. Näiden tutkimusten perusteella on laskettu eripituisilta kasvatusjaksoilta seuraavat vertailevat rehunkäyttöluvut. SALmisen lukuja on täydennetty laidunrehun määrää koskevilla arvioilla.

Ay-hiehojen ja sonnimullikoiden ruokinta ja saavutetut painot JĀÃsKELĀISEN ja SALMISEN mukaan - Data on feeding and weights of Ayrshire heifers and bulls

\begin{tabular}{|c|c|c|c|c|c|c|}
\hline \multirow[b]{2}{*}{$\begin{array}{l}\text { Kasvatusaika, kk ..................................... mths } \\
\text { Growing per., }\end{array}$} & Hieho & Heife & (JÄÄsK & LÄINEN) & \multicolumn{2}{|c|}{$\begin{array}{r}\text { Sonnimullikat } \\
\text { Young bulls } \\
\text { (SALMINEN) }\end{array}$} \\
\hline & 8 & 12 & 24 & 19 & 8 & 19 \\
\hline Elopaino, $\mathrm{kg}-$ Live wght $\ldots \ldots \ldots \ldots \ldots \ldots \ldots . . . . . .$. & 156 & 230 & 350 & $\begin{array}{r}\text { interp. } \\
(306)\end{array}$ & 189 & 353 \\
\hline Teuraspaino, kg - Slaught. wght ........... & 78 & (115) & $(175)$ & (153) & 81 & 167 \\
\hline Täysmaito - Milk .......................... & 53 & 53 & 53 & 49 & 25 & 25 \\
\hline Kuorittu maito - Skimmed milk .......... & 156 & 157 & 157 & 157 & 169 & 169 \\
\hline Kaurajauho - Oat meal .................... & 85 & 115 & 171 & 130 & 30 & 30 \\
\hline Turnipsia - Turnip ........................ & 46 & 128 & 382 & 263 & & \\
\hline Säilörehu - Silage ........................... & & & & & & 134 \\
\hline Heiniä - Hay ............................... & 140 & 373 & 1186 & 826 & 13 & 449 \\
\hline Kev.v.olkia - Straw ........................ & & & 46 & 10 & & \\
\hline Laidunta - Pasture ......................... & & & & & $(280)$ & $(846)$ \\
\hline Yhteensä ry - Total f.u. ................... & 480 & 825 & 1995 & 1435 & 517 & 1653 \\
\hline 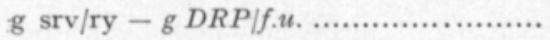 & 167 & 147 & 122 & 129 & 129 & $\left.157^{1}\right)$ \\
\hline
\end{tabular}

Näiden koetulosten lisäksi oli käytettävissä myös KAJANOJAn ja LARPEKSEN (1962) tutkimustuloksia n. 5 kk ikään kasvatettavien lihovasikoiden ruokintakokeista. Myös oli tietoja Nordfeldtin lihovasikoilla ja 24 kk:n ikään kasvatettavilla kastroiduilla sonnivasikoilla suorittamista kokeista (ref. HAKKARAINEN 1966, p. 94-96, 98-104). Viimeksimainituissa kokeissa tutkittiin mm. ruokinnan voimakkuuden vaikutusta, jolloin osoittautui, että vahva ruokinta etenkin toisena sisäruokintakautena johti heikkenevään taloudelliseen tulokseen. Ruotsin hintasuhteissa oli jo v. 1957 edullisempaa kasvattaa eläimet vanhemmiksi kuin teurastaa ne jo vuoden ikäisinä.

Painokehityksessä etenkin ensimmäisen kasvatusvuoden kuluessa voi olla jopa yli $30 \%$ :n eroja ruokinnan voimakkuudesta riippuen. Suunnilleen tätä suuruusluokkaa olevia eroja esiintyi myöskin PoIJärven (1941) 1930-luvulla suorittamissa suomenrotuisten hiehojen kasvatuskokeissa, joissa toisaalta todettiin tuotantoeläimiksi kasvatettavien hiehojen elpyvän varsin tyydyttävästi

1) Laitumen sadon srv-sisällöksi arvioitu $163 \mathrm{~g} / \mathrm{ry}$ The pasture yield estimated according to feed tables 
myöskin niukan alkuruokinnan jälkeen. Myös täysmaidon käytön suhteen on voitu viime vuosikymmenten kokemusten jälkeen huomattavasti tinkiä, vieläpä korvata se kokonaankin erilaisilla halvemmilla valmisteilla.

KoIviston ja YLISELÄN (1964) tutkimukset viittaavat toisaalta siihen, että markkinoille tulevien sonni- ja lehmävasikoiden teuraspainot v. 1961 olivat verraten tyydyttäviä etenkin eteläosassa maata. Pohjois-Suomessa olivat sekä suomen- että ay-rotuisten teurasvasikoiden painot $10 \mathrm{~kg}$ tai vieläkin alempia kuin Etelä-Suomessa. Kevättalvella teurastetut syysvasikat ovat olleet painavampia kuin kevät- ja kesävasikat.

Teurasvasikoiden ja -nautojen kasvatuksen taloudellisuus lienee yleensä yhdistettävissä myös siihen, mihin aikaan kasvatettavat vasikat otetaan ja miten kauan niitä pidetään. Osaksi HAKKARAISEN laudaturtyössään (1966) tekemän selvityksen nojalla valittiin tätä tutkimusta varten neljä kasvatusmah dollisuutta, joita on tässä merkitty kirjaimilla A-D.

A. Tämän vaihtoehdon mukaan vasikat otettaisiin elo-syyskuussa, ja kasvatettaisiin seuraavan laidunkauden alkuun $10 \mathrm{kk}$ ikäisiksi. Tällöin ruokinta on täysin sisäruokintakauden rehuihin perustuvaa, mutta toisaalta vasikat tulevat markkinoille aikana, jolloin lihan kilohinta on 24 p korkeampi kuin syksyllä.

B. Vasikat otetaan tammi-helmikuussa ja kasvatetaan 8 kauukauden ikään, mihin mennessä ne voivat käyttää verraten runsaasti laidunrehua. Tämä vaihtoehto sopeutuu myöskin maidontuotantoa varten tehtyyn suunnitelmaan.

C. Vasikat otetaan loka-marraskuussa ja kasvatetaan teurasnaudoiksi kahden laidunkauden yli.

D. Lähinnä SALMISEN kasvatusmallia seuraten otetaan aikaisia kevättalven vasikoita, jotka kasvatetaan 19 kk ikään kahden laidunkauden yli. Laidunkauden lasketaan kuitenkin olevan kuukautta lyhyempi kuin Pohjois-Savon koeasemalla.

Vaihtoehtoja vastaavat ruokintayhdistelmät ja painotiedot esitetään seuraavassa asetelmassa:

B

C

D

\begin{tabular}{|c|c|c|c|c|}
\hline $\begin{array}{l}\text { Vasikat syntyneet - Calf births } \\
\text { Ikä teurastettaessa, kk } \\
\text { Age when slaughtered, mths }\end{array}$ & $\begin{array}{c}\text { VIII - IX } \\
10\end{array}$ & $\begin{array}{c}\mathrm{I}-\mathrm{II} \\
8\end{array}$ & $\begin{array}{c}\mathrm{X}-\mathrm{XI} \\
24\end{array}$ & $\begin{array}{c}\mathrm{II}-\mathrm{III} \\
19\end{array}$ \\
\hline \multicolumn{5}{|l|}{ Rehujen käyttö ry - Use of feed f.u. } \\
\hline Täysmaitoa - Whole milk ....................... & 16 & 16 & 16 & 25 \\
\hline Kuorittu maito - Skimmed milk ............... & 75 & 106 & 75 & 169 \\
\hline Öljykakkuja - Oil cakes .......................... & 56 & 80 & 80 & - \\
\hline Ohraa - Barley .................................... & 112 & 120 & 120 & 30 \\
\hline AIV-säilörehu - Silage ............................ & 143 & - & 250 & 152 \\
\hline Heinää - Hay .................................. & 248 & 100 & 704 & 491 \\
\hline Laidunta - Pasture ................................. & - & 240 & 1180 & 778 \\
\hline Yhteensä ry - Total f.u. ....................... & 650 & 662 & 2425 & 1652 \\
\hline Teuraspaino - Slaught & 120 & 110 & 235 & 167 \\
\hline
\end{tabular}


Kuten edellisestä selviää, ei 5 kk:n lihovasikoita ole otettu vaihtoehdoksi. Lähinnä on ajateltu, että kysymykseen tulevat ensi sijassa nurmenviljelyn tuotteita käyttävät vaihtoehdot. Pitemmälle jatkuvasta käsittelystä pudotettiin pois myöskin vaihtoehto $\mathrm{A}$, jolla ei tuntunut olevan mahdollisuuksia pysyä mukana kilpailussa.

Katetuottoa laskettaessa teuraspainokilon hinta oli vaihtoehdossa B 2:82, vaihtoehdossa C 2:43 ja vaihtoehdossa D 2:45, joita sovellettiin hintatilanteissa (a) (-:36) ja (b) $(-: 25)$. Vuotta 1972 varten tehdyssä maidon hintatilanteen (c) $(-: 70)$ mukaisessa laskelmassa hintoina käytettiin 6:50, 6:80 ja 6:50.

Katetuottolaskelmassa luettiin muuttuviin kustannuksiin vasikan arvo, täysmaidon arvo, hinnoiteltuna eri hintatilanteissa samoin kuin lypsykarjatalouden katetuottolaskelmassa sekä edelleen öljyväkirehujen, kivennäisaineiden, viljan jauhatuskustannusten, sähkön ja eläinlääkintämenojen sekä eläinpääoman koron aiheuttama kustannus kasvatusajalta. Kuorittu maito on edellytetty palautettavaksi meijeriltä, kuitenkin 3 p kilolta vastaavaa kuljetusmaksua vastaan. Kuivikkeista maksettavan hinnan on katsottu vastaavan lannan arvoa.

Kun otetaan huomioon, että ruokintakustannus riippuu myös maidon hinnasta, muodostuu katetuotto vaihtoehdoissa B-D seuraavasti:

\begin{tabular}{|c|c|c|c|}
\hline Lihan myyntiarvo (a) ja (b) - Sales of beef $\ldots \ldots \ldots \ldots . . . .$. & $\begin{array}{c}\text { B } \\
310\end{array}$ & $\begin{array}{l}\mathrm{C} \\
572\end{array}$ & $\begin{array}{l}D \\
409\end{array}$ \\
\hline \multicolumn{4}{|l|}{ Muuttuvat kustannukset - Variable costs } \\
\hline 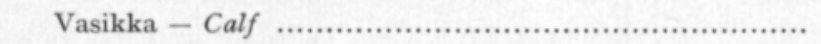 & 50 & 50 & 50 \\
\hline \multirow{2}{*}{ 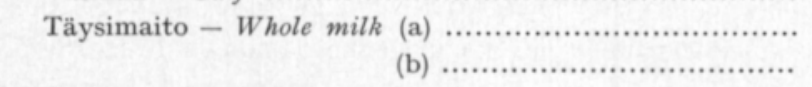 } & 22 & 22 & 36 \\
\hline & 16 & 16 & 25 \\
\hline Kuorittu maito - Skimmed milk $\ldots \ldots \ldots \ldots \ldots \ldots \ldots \ldots \ldots$ & 29 & 20 & 46 \\
\hline 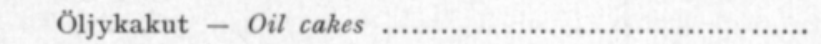 & 44 & 44 & - \\
\hline 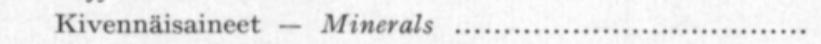 & 3 & 5 & 5 \\
\hline Viljan jauhatuskustannukset - Grain grinding ............... & 2 & 2 & 1 \\
\hline 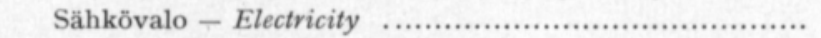 & 1 & 2 & 2 \\
\hline Eläinlääk.kustannukset - Veterinary $\ldots \ldots \ldots \ldots \ldots \ldots \ldots$ & 5 & 6 & 6 \\
\hline Eläinpääoman korko - Interest on livestock cap. ................ & 6 & 34 & 20 \\
\hline \multirow{2}{*}{ 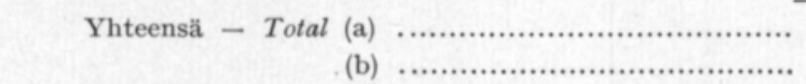 } & 162 & 185 & 166 \\
\hline & 156 & 179 & 155 \\
\hline Katetuotto (a) & 148 & 387 & 243 \\
\hline 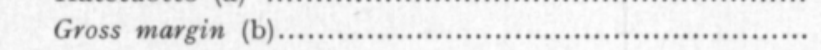 & 154 & 393 & 254 \\
\hline
\end{tabular}

Hintatilanteessa (c) katetuotot ovat vastaavasti 554, 1413 ja 917 mk.

Naudanlihan tuotanto on LP-laskelmassa sidottu maidontuotantoon, mikä luovuttaa enintään 0.75 vasikkaa lehmää kohden sekä kaiken voinvalmistuksessa syntyvän kuoritun maidon, sikäli kuin lihantuotanto pystyy kilpailemaan muiden tuotannonhaarojen kanssa.

\section{Sikatalouden katetuottolaskelma}

Sikatalous on ajatelțu suunnattavaksi lähinnä kevyen lihotussian tuottamista varten, pyrkien paikalliseen omavaraisuuteen myöskin porsaiden tuotta- 
misessa. Tällä tavoin on mahdollista käyttää nimenomaan yli alueen tarpeen ulottuvan maidontuotannon sivutuotteita hyödyksi, samoinkuin myöskin ohrał ja perunaa sikäli kuin näiden viljely osoittautuu kilpailukykyiseksi viljan oston kanssa.

Lihotussian rehukulutus on laskettu $6-7$ viikon ikäisestä porsaasta (keskipaino $15 \mathrm{~kg}$ ) n. $7 \mathrm{kk}$ ikäiseen $105-110 \mathrm{~kg}$ :n elopainoiseen sikaan, jonka teuraspainoksi oletetaan $77.5 \mathrm{~kg}$. Elopainon lisäkasvukiloa kohden edellytetään tarvittavan 3.8 ry, joten koko rehunkulutus on 352 ry.

Kuorittua maitoa suositellaan sekä tanskalaisissa että ruotsalaisissa ohjeissa annettavaksi n. 40-50 ry kasvatettavaa lihotussikaa kohden. Määrä voisi Kainuun oloissa olla suurempikin. Loppuosa rehutarpeesta on tässä ajateltu tyydytettäväksi ohralla tai perunalla, tai mieluummin kumpaakin osaksi käyttäen. Lienee paikallaan tehdä laskelma ohran hinnan perusteella; ruokintasuunnitelmaa toteutettaessa voidaan peruna ottaa ohran sijaan, ja erilaiset juurikasvit ja pienessä määrin säilörehu myös ottaa kuvaan. LP-laskelmassa on ohran määrä asetettu 245 ry:ksi ja perunan määrä 62 ry:ksi, näiden keskinäistä korvattavuutta ei ole saatu mukaan, myös muut rehuvaihtoehdot on jätetty pois. Ohra oletetaan aggregoidussa laskelmassa ostetuksi hintaan -:32 joko omasta maataloudesta tai sen ulkopuolelta; uusimmassa laskelmassa ohranviljely tulee muuttuvine kustannuksineen itse ohjelmaan, mutta vaihtoehtona on ohran ostaminen hinnalla, joka maidon hintatilanteissa (a) ja (c) on asetettu 50 p:ksi tilanteessa (b) 35 p:ksi ry:ltä.

Porsaan tuotantokustannusta arvioitaessa voitaneen lähteä siitä, että siitosemakon ruokinta (1300 ry vuodessa) maksaa n. 380:- , hoitokustannus n. 200:ja muita kustannuksia on n. 80:-, eli yhteensä 660:- Jos eloonjäävien porsaiden luku vuodessa arvioidaan varovasti 12 kappaleeksi, tullaan hintaan $\mathbf{5 5}$ mk porsasta kohden. Kun otetaan huomioon erilaisia muitakin muuttuvia kustannuksia, sianlihantuotannon katetuottolaskelma muodostuu seuraavanlaiseksi.

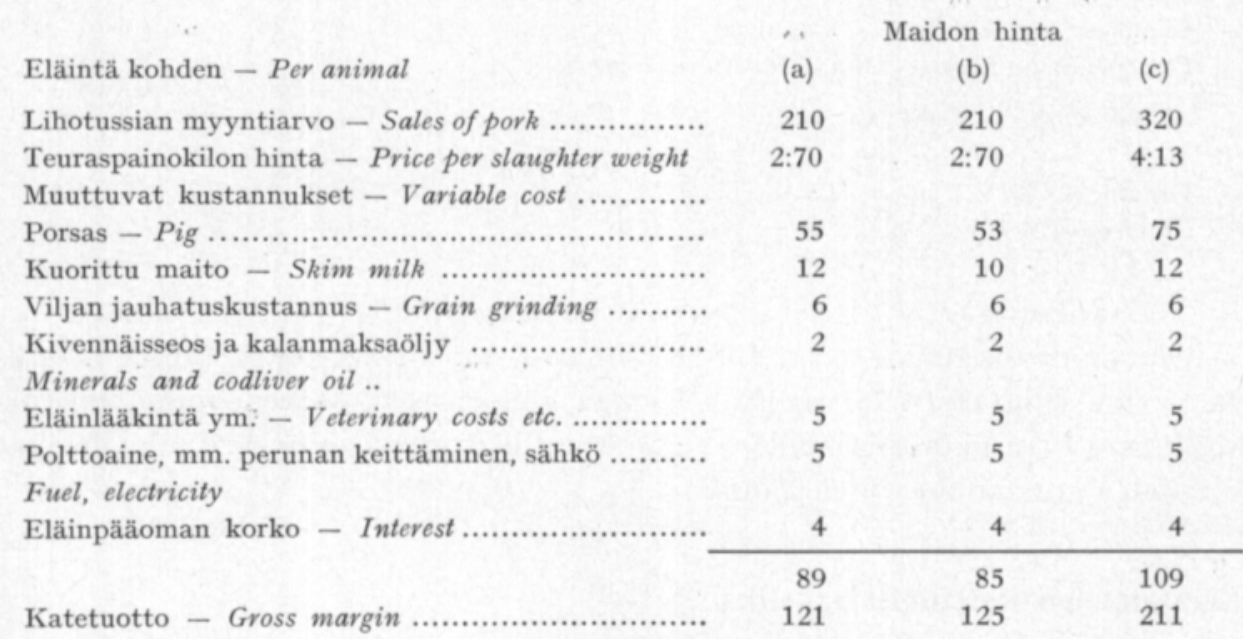

Hintatilanteessa (b) otaksutaan kuoritụn maidon olevan vähän halvempaa ja samoin porsaiden hinnan, johon maidon hinta vaikuttaa. 


\section{Lammastalouden katetuottolaskelma}

Lampaiden pito oli Kainuussa ennen sotaa suhteellisesti yleistä. Kainuulainen lammas oli tunnettu hyvän sikiävyytensä ja suhteellisesti suuren kokonsa ja nopeakasvuisuutensa johdosta. Maamme lampaanjalostukselle on näiltä alueilta saadulla siitoseläinaineksella ollut huomattava merkitys, ja ehkä voi sanoa, että suomalaisen lampaan myös kansainvälisesti viime aikoina saavuttama maine on perustunut tältä suunnalta löydettyyn eläinainekseen.

Mutta Kainuusta lammas on tutkimuksen ajankohtana ja sen jälkeen tekisi mieli sanoa arveluttavan nopeasti häviämässä. Vielä 1950 oli Kajaanin maatalouskeskuksen alueella 21000 lammasta eli jotenkin sama määrä kuin v. 1939, mutta v. 1959 niitä oli 8400 , eli vähemmän kuin puolet ja vuoden 1969 maatalouslaskennan mukaan vain kymmenes osa vuoden 1950 luvusta. Tutkimuksen ajankohtana tapasi vain harvoilla tutkimustiloilla lampaita.

Yleinen käsitys on, että lampaat eivät menesty alavilla mailla, jollaisia tutkimusalueella lähinnä esiintyy. Kainuun lampaita lienee aikaisemmin laidunnettu etupäässä ylempänä olevilla vaaramailla. Jos ajatellaan lammastalouden tuomista tutkimustilojen tuotantosuunnitelmiin, olisi koetoiminnalla tarkoin selvitettävä ne lähinnä suolimadoista johtuvat vaarat, jotka turvemaan laitumilla ovat uhkaamassa sekä niiden torjumismahdollisuudet. Perä-Pohjolan koeasemalla lampaita on menestyksellä laidunnettu turvemaalla, ja Islannissa tapaa tätä menettelyä käytännössä. Erään islantilaisen agronomin mukaan tautivaaraa voidaan vähentää siirtämällä lampaita suhteellisesti usein lohkoilta toisille, niin että lohkot pysyvät riittävän pitkän ajan koskemattomina.

Mikäli lampaita laidunnetaan pelkästään kivennäismailla, on otettava huomioon yleensä suuremmat vaihtoehtoiskäytössä saatavan hyödyn menetykset. Mm. korkeimmat metsätalouden tuotot saadaan, kuten myöhemmin esitettävästä selviää, kivennäismailla. Ohjelmissamme edellytettiin lammastalous sijoitettavaksi turvemaan nurmiviljelyksille. Koska tätä kohtaan tunnettiin tiettyä epäilyä, lammastalous jätettiin pois eräistä vaihtoehtoisesti esitetyistä rinnakkaisohjelmista.

Lammastalouden katetuottolaskelmaan tehtiin disaggregoituun ohjelmaan siirryttäessä eräitä muutoksia. Seuraavassa selostetaan vain lopullisia laskelmia, kuitenkin viitaten pariin tuntuvammin vaikuttaneeseen muutokseen.

Uuhien keskimääräinen karitsaluku, jossa vain eloonjäneet on laskettu mukaan, on arvioitu olevan 1.8. Se vastaa hyvänlaisia olosuhteita, mutta jää alemmaksi esim. jalostusyhdistyksen tuotantotarkkailutiloilla saatua tulosta (vrt. RYyNÄNEN 1969, p. 108). Karitsojen keskim. teuraspaino on arvioitu 11.5 $\mathrm{kg}$ :ksi, uuhien teuraspainon ollessa $25 \mathrm{~kg} ; 20 \%$ uuhista uusitaan vuosittain. Pässi on oletettu pidettäväksi 10 uuhta kohden, mutta sen rehu- ym. kustannukset on otettu lukuun uuhta kohden tehdyssä laskelmassa. Lihan hinta 1959-63 oli 3:06 kilolta, vuoden 1972 hinta (vaihtoehto c) pn 6:80. Villan hinta oli 1959-63 6:63, 1972 7:79.

Kokonaistuotto on tällöin ollut uuhta kohden vuodessa mk. (Gross return per ewe, $m k$ ): 
Lihaa karitsoista _ Lamb

uuhesta ja pässistä

Villaa karitsoista - Lamb wool

- uuhesta ja pässistä - Wool from ewe \& ram $20.7 \mathrm{~kg}$

(a)

5.25

1.8

2.75 (b)

63

(c)

16

140

11

36

18

108
14

21

Rehunkulutus, johon sisältyy myös karitsain ja pässin rehunkäyttö on, käyttäen vertailuperustana myös RYYNÄSEN tutkimusta (p. 117) arvioitu seuraavaksi.

\begin{tabular}{|c|c|}
\hline Kuorittua maitoa - Skim milk ................. & 10 \\
\hline 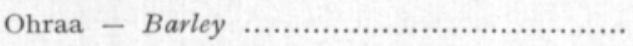 & 40 \\
\hline 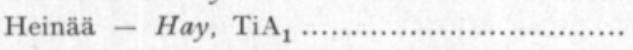 & 140 \\
\hline 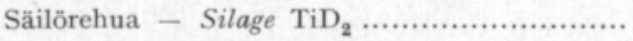 & 50 \\
\hline Laidunta - Pasture L ............................ & 250 \\
\hline
\end{tabular}

Koska viljelmällä tuotetut rehut sisältyvät LP-laskelmaan, ei niistä aiheutuvia kustannuksia, lukuunottamatta kuoritun maidon kuljetuskustannuksia, vähennetä katetuotosta.

Katetuoton vähennyseriin on sitävastoin sisällytetty seuraavat erät (Deductions):

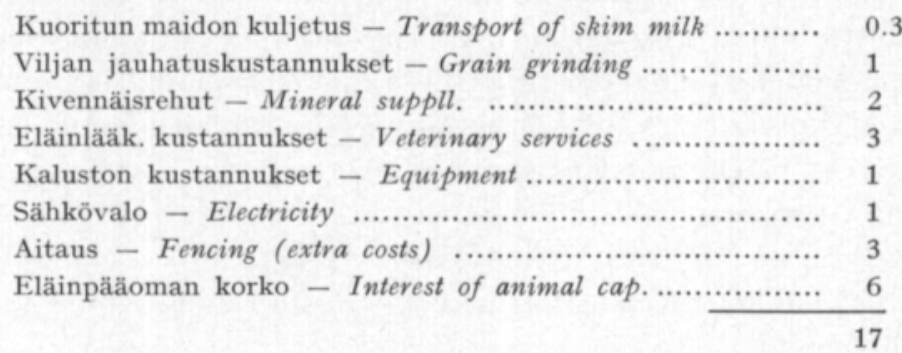

Tässäkin laskelmassa on kuivikekustannus pantu vastaamaan lannan arvoa. Katetuotot muodostuvat eri hintatilanteissa seuraaviksi:

Katetuotto uuhta kohti - Gross margin per ewe

(a)

92 (b)

92 (c) 194

\section{Ohranviljelyn muuttuvat kustannukset}

Ohran hehtaarisadot olivat tutkimustiloilla vv. 1959-63 keskimäärin $1470 \mathrm{~kg}$. Tänä jaksona esiintyi yksi täydellinen katovuosi (1962), jolloin saatiin vain n. $300 \mathrm{~kg}$ jotenkin arvotonta tuotetta hehtaarilta. Koillis-Suomen alueen kirjanpitotilojen keskisadot olivat samalla jaksolla $1743 \mathrm{~kg}$, ja vuoden 1962 sato $702 \mathrm{~kg}$. Perä-Pohjolan koeaseman talousviljelyksillä saatiin samoina vuosina keskimäärin $2700 \mathrm{~kg}$ ja vuosina $1963-672320 \mathrm{~kg} / \mathrm{ha}$.

Hyvän vertailukohdan satotulosten arvostelemiseksi tarjoaa myös Maatalousseurojen Keskusliiton ja Pellonraivaus Oy:n Koillis-Suomen havaintotiloja kos- 
keva aineisto. (Tutkimustulokset havaintotilatoiminnasta ...). Havaintotiloilla saatiin vv. 1952 - 63 ohrasta $1393 \mathrm{~kg}$ jyviä ja $1964 \mathrm{~kg}$ olkia hehtaarilta. Näillä tiloilla käytettiin ohralle keskimäärin 18.4 to karjanlantaa, $17 \mathrm{~kg}$ väkilannoitteiden typpeä, $68 \mathrm{~kg}$ fosforihappoa ja $84 \mathrm{~kg}$ kalia ha kohden. Huonoimpana vuonna (1956) sato jäi 929 kiloon.

Tämän tutkimuksen kannalta olisi hyödyllistä selvittää, missä määrin turveja kivennäismaiden sadot vastaavat toisiaan. Havaintotiloilta saatavana olevien tietojen mukaan olemme laskeneet keskiarvot pelkästään turvemailla olevilta ohranviljelyksiltä (6 tilaa). Keskisadoksi on saatu 1220 kg. Kun turvemaan viljelykset ovat hallanarempia kuin kivennäismaiden, lienee varovaisinta arvioida keskisato pienemmäksi. Seuraavissa laskelmissa on kivennäismaan ohran sadoksi pantu $1700 \mathrm{~kg}$ ja turvemaiden keskisadoksi $1200 \mathrm{~kg}$.

Koska karjanlanta yleensä ajetaan muokkauksen alaisille maille, tutkimustilojen olosuhteissa kevätvilja saanee yleensä verraten runsaan karjanlantalannoituksen. Edellämainittujen havaintotilojen ohra on kivennäismailla saanut n. 18 to, turvemailla n. 16 tonnia karjanlantaa. Lisäksi havaintotiloilla on käytetty vv. $1952-59$ keskim. $83 \mathrm{~kg}$ typpi-, $359 \mathrm{~kg}$ fosfaatti- ja $168 \mathrm{~kg}$ kalilannoitteita. Hehtaarin kustannus pelkistä väkilannoitteista nousee vallinneiden hintojen mukaan n. 84 markkaan, kun taas karjanlanta hinnoitettuna $7 \mathrm{mk}$ mukaan tonnilta nostaisi kustannuksen $210 \mathrm{mk}$ :aan. Suomussalmen tilojen keskimääräinen väkilannoitekustannus on ollut $135 \mathrm{mk} / \mathrm{ha}$, ja karjanlannan arvon on katsottu vastaavan kuivikeolkien arvoa. Kun ohra suojaviljana kiinteästi kuuluu nurmenviljelyn kiertoon, ei liene syytä sitä kuormittaa keskimääräistä suuremmalla lannoituskustannuksella, varsinkin kun eräät lähialueilta saadut tiedot viittaavat siihen, että esim. typpilannoitusta on kevätviljoille käytetty vähemmän kuin heinänurmille.

Ohranviljelyn muuttuvat kustannukset ja katetuotot eri vaihtoehdoissa näkyvät seuraavasta.

\begin{tabular}{|c|c|c|c|c|}
\hline \multirow{3}{*}{$\begin{array}{l}\text { Tekniikka }- \text { Techniques } \\
\text { Sato }- \text { Yield }\end{array}$} & \multicolumn{2}{|c|}{$\begin{array}{c}\text { Kivennäismaat } \\
\text { Mineral soils }\end{array}$} & \multicolumn{2}{|c|}{$\begin{array}{l}\text { Turvemaat } \\
\text { Peat soils }\end{array}$} \\
\hline & I & II & I & II \\
\hline & \multicolumn{4}{|c|}{ Sato - Yield } \\
\hline jyviä - grain .................................... & 1700 & 1700 & 1200 & 1200 \\
\hline 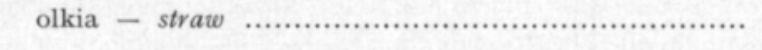 & 2500 & 2500 & 2400 & 2400 \\
\hline Arvo - Value ................................................... & 610 & 610 & 456 & 456 \\
\hline \multicolumn{5}{|l|}{ Muuttuvat kustannukset - Variable costs } \\
\hline 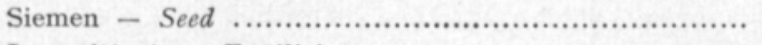 & 60 & 60 & 60 & 60 \\
\hline 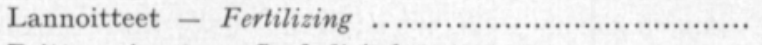 & 135 & 135 & 135 & 135 \\
\hline Peittausaineet - Seed disinfectants ........................ & 10 & 10 & 10 & 10 \\
\hline Rikkakasv. torjunta - Weed control ........................ & 20 & 20 & 20 & 20 \\
\hline \multicolumn{5}{|l|}{ Puinti - Threshing } \\
\hline 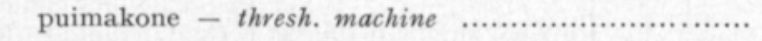 & 9 & - & 9 & - \\
\hline leikkuupuimuri - combine harvester ..................... & - & 76 & - & 76 \\
\hline Kuivaus, polttoaine - Drying, fuel ......................... & 6 & 6 & 5 & 5 \\
\hline Traktorityö - Tractor ....................................... & - & 30 & - & 29 \\
\hline Raivauskust. korko - Interest of land clearing costs .... & 42 & 42 & 33 & 33 \\
\hline Muuttuvat kustannukset - Variable costs ................. & 282 & 379 & 272 & 368 \\
\hline Katetuotto - Gross margin ................................. & 328 & 231 & 184 & 88 \\
\hline
\end{tabular}


Uudessa LP-laskelmassa on muuttuviksi kustannuksiksi otettu nettokustannukset, joissa olkien arvo on vähennyseränä. Tuotetun karjanlannan arvon katsotaan tällöin jakaantuvan verraten tasaisesti koko peltoalalle.

\section{Perunanviljelyn katetuotto ja muuttuvat kustannukset}

Tutkimustiloilla on perunan keskisato ha:Ita ollut verraten korkea, n. 15500 $\mathrm{kg} / \mathrm{ha}$. Tuhoisat hallat v. 1962 painoivat tämän vuoden tuloksen $8700 \mathrm{~kg}$ :aan, tilaryhmässä B aina $7150 \mathrm{~kg}$ :aan saakka ja vuoden 1964 sato $(10750 \mathrm{~kg}$ ) jäi myös huomattavasti alle keskitason, kun taas v. 1960 saatiin jopa $22500 \mathrm{~kg}$ hehtaarilta.

Tätä tutkimusta varten ei ole selvitetty kysymystä perunan viljelyvarmuudesta ja määrällisistä sekä laadullisista sadoista turvemailla. Laskelmissamme on peruna edellytetty viljeltäväksi kivennäismailla.

Kun viljelykasveittaisia tietoja lannoituksesta ei onnistuttu tutkimustiloilta saamaan, on perunan lannoituskustannukset pyrittävä arvioimaan vertailuaineistojen nojalla. Edellämainituilla havaintotiloilla käytettiin vv. 195258 keskim. 42.5 to karjanlantaa, $137 \mathrm{~kg}$ typpilannoitteita, $346 \mathrm{~kg}$ fosfaatti- ja $210 \mathrm{~kg}$ kalilannoitteita perunalle. Oletettaessa käytetyn tavallisimpia lannoitteita ja laskettaessa karjanlannan arvoksi $7:-$ to, päädyttäisiin vallinneiden väkilannoitehintojen mukaan $391 \mathrm{mk}$ hehtaarikustannukseen. Ensimmäisessä LP-laskelmassa, jota varten tehdyssä katetuottolaskelmassa karjanlannan arvo oli laskettu $4 \mathrm{mk} /$ to, koko lannoituskustannus oli arvioitu $260 \mathrm{mk}$ :ksi, mikä oli jotenkin rehuyksikkösadon suhdetta vastaavassa määrässä korkeampi kuin ohran.

Kun perunan markkinointimahdollisuudet alueen ulkopuolelle ovat olleet vähäisiä, on ruokaperunan viljely ajateltu rajoitettavaksi viljelijäperheen kulutusta vastaavaksi. Otettaessa huomioon $8 \%$ :n suuruiseksi arvioitu varastointitappio ja siemeneksi varauksen lisäksi myös verraten suuri (tässä keskim. n. $40 \%$ :ksi arvioitu) vain rehuperunaksi kelpaava osa sadosta, on viljelijäperheen kulutustarpeen tyydyttämiseksi tarpeellinen perunanviljelyala arvioitu 0.24 hehtaariksi. Sivutuotteena tältä alalta saadaan n. $1400 \mathrm{~kg}$ eli $280 \mathrm{ry}$ rehuperunaa. Ruokaperunan hinta on katsottu voitavan arvioida Sosiaalisen tutkimustoimiston kuluttajahintatilaston perusteella, kun taas rehuperunan hintaa määrättäessä on arvioperustana ollut ohran hinta. Uudessa LP-laskelmassa on rehuperunan viljely erotettu eri tuotantoprosessiksi, joka tuottaa rehua lähinnä sikatalouteen.

Ruokaperunaa koskevalta osalta on seuraava laskelma katetuottolaskelma, rehuperunan osalta arvioidaan mnegatiivinen katetuotton, ts. muuttuvat kustannukset. 


\begin{tabular}{|c|c|c|}
\hline & $\begin{array}{c}\text { Hehtaaria } \\
\text { kohden } \\
\text { per ha }\end{array}$ & $\begin{array}{l}\text { Arvo } \\
\text { Value }\end{array}$ \\
\hline Kokonaissato, $\mathrm{kg}$ ha - Crop yield ........ & $15000 \mathrm{~kg}$ & \\
\hline 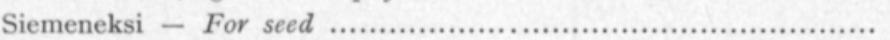 & 2700 & \\
\hline 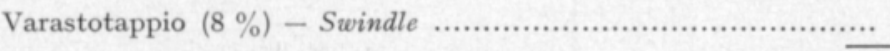 & 1200 & \\
\hline Nettosato - varastotappio - Differ. ........................... & $11000 \mathrm{~kg}$ & \\
\hline Ruokaperunaksi (väh.h.) - for food (ret.pr.) ........................ & 5000 & 1150 \\
\hline Rehuperunaksi - Feed use (à 6 p/kg) ............................. & 6000 & 360 \\
\hline Muuttuvat kustannukset - Variable costs & & \\
\hline Lannoituskustannus - Manure and fertilizers .................. & & 260 \\
\hline 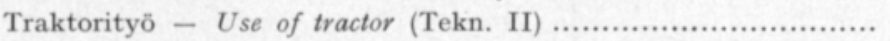 & & 107 \\
\hline Työkoneiden vuokra - Use of special mach. (Techn. II) .......... & & 30 \\
\hline Rikkaruohotorjunta - Weed control ................................. & & 20 \\
\hline Varastosuojan lämmitys idätysaikana - Fuel ....................... & & \\
\hline Raivauskustannusten korko - Interest of land clearing capital ...... & & 42 \\
\hline Muuttuva kust. tekn I ........................... & & 327 \\
\hline 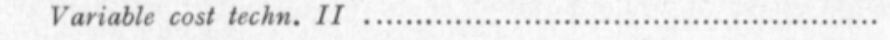 & & 464 \\
\hline 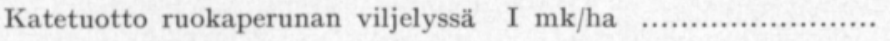 & & 1183 \\
\hline 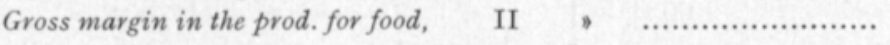 & & 1046 \\
\hline 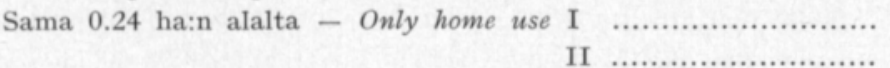 & & $\begin{array}{l}284 \\
251\end{array}$ \\
\hline
\end{tabular}

Vuoden 1972 vähittäishinnoin $(-: 45 / \mathrm{kg})$ laskettuna katetuotto ha kohden muodostuu 2017 ja 1886 mk:ksi hehtaarilta, vastaavissa tekniikoissa. 0.24 ha:n alalta siis saadaan $484:-$ ja $453:-$. 


\section{Metsätalous uudistilan taloussuunnitelmassa}

Tutkimuksemme tarkoituksena on selvittää, miten laajaa metsätaloutta voidaan suositella harjoitettavaksi kainuulaisella uudistilalla, edellyttäen että tämä tuotanto pääasiassa hoidetaan viljelijäperheen omaa työvoimaa käyttäen. Päähuomio kiinnitetään siihen, miten suureen metsäpinta-alaan olisi pyrittävä täystyöllisyyden saavuttamiseksi maatalouden ja metsätalouden täydentäessä toisiaan, ja miten suureksi voidaan arvioida metsätalouteen käytetystä työstä saatava tulo. Metsätaloutta harjoittava maanviljelijä saa tietenkin tulonsa myyntituloina, joihin sisältyy myös hankintatyön korvaus, silloin kun viljelijä ne itse suorittaa. Mutta myyntituloilla on peitettävä varsin huomattavia maaja puusto-omaisuuden ylläpidosta johtuvia kustannuksia, joten sitä ei voida edes suurimmalta osaltakaan katsoa työtuloksi.

Saattaa olla epärealistista ajatella, että viljelijä voisi vuosittain sijoittaa suunnilleen saman määrän omaa työtänsä metsätalouteen, etenkin jos asetetaan vaatimukseksi, että hankintatyöt on aina suoritettava omalla työvoimalla. Hankintojen taloudellisesti järkevä suorittaminen edellyttää miltei aina niiden keskittämistä, joten yhden maatilan piirissä ei normaalisesti kannata suorittaa samansuuruisia hankintoja vuosittain. Tämä ei kuitenkaan ratkaisevasti vähennä tässä suoritettavien laskelmien arvoa. Erilaisia metsänhoitotoimenpiteitä voidaan suorittaa eri vuosina, ja monet niistä voidaan sijoittaa verraten vapaasti vuoden eri jaksoille; sitäpaitsi voimme ajatella, että uudistilalliset hakeutuvat toistensa luokse ansiotyöhön suurempien hankintojen ollessa kysymyksessä. Eri asia on tietysti, että puun menekkimahdollisuuksissa esiintyvät vaihtelut saattavat vaikuttaa sen, ettei laskettuja työmahdollisuuksia ole jonakin aikana.

Metsätalouden ihmistyövoiman tarve voidaan mitoittaa välttämättömimmät päätehakkaukset edellyttävän minimiohjelman mukaan, mutta tällöin ei voitaisi edellyttää metsätaloudesta saatavan edullisinta taloudellista tulosta. Metsän tuottoa voidaan kuitenkin tiettävästi lisätä erilaisilla ihmistyön käyttöä vaativilla toimenpiteillä, joihin uudistilallisperheen työtä voidaan sopivasti sijoittaa. Toimenpiteiden tuottoa lisäävä vaikutus tosin saattaa ratkaisevasti riippua siitä ammattitaidosta, jolla niitä koskevat suunnitelmat laaditaan ja coteutetaan. Nykyisin voivat viljelijät kuitenkin saada siihen asiantuntevaa apua, joista he maksavat metsätalouden kiinteisiin kustannuksiin luettavan pakollisen metsänhoitomaksun muodossa.

Tällaisina metsän tuottoa kohottavina ihmistyötä vaativina toimenpiteinä 
mainittakoon kasvatushakkuut, metsäojitukset vesiperäisillä mailla, oksien karsiminen arvopuista, taimistojen hoito- ja varsinaiset metsänviljelytoimenpiteet, kylvö ja istuttaminen. Koska on hyvin vaikeata tarkasti arvioida näiden toimenpiteiden vaikutuksia tulevaan tuotokseen, olisi monen mielestä varmaankin syytä jättää niitä koskevien laskelmien suorittaminen johonkin myöhempään aikaan, jolloin enemmän Pohjois-Suomea koskevia metsänparannustoimenpiteiden vaikutuksia selvittäviä tutkimustuloksia mahdollisesti on käytettävissä. Tämän tutkimuksen tavoitteet jäisivät kuitenkin saavuttamatta, jos ei edes yritetä tehdä arvioita tällaisten töiden tuottavuudesta. Myöskin metodin kehittämistä silmälläpitäen tällaiseen yritykseen on syytä ryhtyä.

\section{Puun tuotosmahdollisuutta koskevia arvioita}

Kainuun olosuhteita vastaavia kasvu- ja tuottotaulukoita ei vielä tutkimuksen alkuvaiheissa ollut käytettävissä. Perä-Pohjolan leveysasteilla $66^{\circ}-68^{\circ}$ olevista täystiheistä luonnonmänniköistä oli sitävastoin ILvEssaLon (1937) laatimat taulukot kolmelta metsätyypiltä, ja maan eteläpuoliskosta, keskimäärin leveysasteella $62^{\circ}$ sijaitsevista koeala-aineistoista on useita erilaisten luonnonsekä myös hoidettujen metsiköiden kasvu- ja tuottotaulukoita käytettävissä (Koivisto 1959). Heikurainen (1959, p. 96-100) on tarkastellut ojitettujen soiden juoksevan vuotuisen kuutiokasvun suhdetta leveysasteittain ja myös itäja länsisuunnassa, ja vaikka kangasmetsien kasvueroja ei hänen mukaansa ole syytä rinnastaa hänen esittämiinsä tuloksiin, osoittavat ne suuntaa ja ovat sopusoinnussa aikaisempien viimeksimainittuja metsiä koskevien tutkimustulosten kanssa.

Tämän tutkimuksen ollessa osaksi jo käsikirjoitusvaiheessa ilmestyi ILvEsSALon erityisesti Kainuun metsiä koskeva uusi tutkimus (1967). Sen tuloksia oli mahdollista käyttää jo v. 1968 julkaisemamme ennakkotiedonannon laskelmissa (PıнкаLA, 1968, p. 7-9). Näin on myös ollut mahdollista saada alueen olosuhteisiin erityisen hyvin soveltuvia perustietoja.

Tutkimustilojen kasvullisesta metsästä on tiloja perustettaessa $10.3 \%$ luettu mustikkatyyppiin (MT), $52.5 \%$ puolukkatyyppiin (VT) ja $4.5 \%$ kanervatyyppiin (CT). Myöhemmin on Pohjois-Suomen metsien luokittelussa siirrytty uusiin tyyppinimikkeisiin. Valtion metsien inventoinnissa 1951-55 ovat Suomussalmen hoitoalueen mäntymetsät sijoittuneet suurelta osalta variksenmarja-puolukkatyyppiin (EVT) ja varpu-jäkälätyyppiin (ErClT). Jos katsomme että viimeksimainittujen kahden tyypin kohdalla vallitsee likimäräinen vastaavaisuus (VT $=$ EVT ja $\mathrm{CT}=\mathrm{ErClT})$, voinemme pitää ILvEssalon tuottotaulukoita mäntymetsien kohdalta laskelmien lähtökohtana. Suomussalmella saadaan kuitenkin todennäköisesti jonkinverran korkeampia tuotoksia kuin Perä-Pohjolan alueella. Heikuraisen (1959, p. 107) esittämän karttakuvion perusteella voidaan päätellä, että Etelä-Suomen, tutkimusalueemme ja Perä- 
Pohjolan kasvuluvut ovat suunnilleen suhteessa 100:64:53; tutkimusalueen luvut siis n. $20 \%$ yli Perä-Pohjolan lukujen. Tämä arviointi onkin Ilvessalon Kainuuta koskevien lukujen mukaan osoittautunut suunnilleen paikkansapitäväksi.

Vertailupohjaa voidaan saada laskelmiamme varten myös niistä verraten lukuisista tuottotaulukoista, joita Petterson (1955 ja 1963) on julkaissut Pohjois-Ruotsin luontaisella uudistumisella syntyneistä ja AndERsson (1963) vastaavasti istutetuista havumetsiköistä. PETTERSON asetti aikanaan päämääräkseen erilaisilla harvennuksilla käsiteltyjen metsikköjen määrä- ja arvotuotannon selvittämisen, ja ANDERSSON on puolestaan pyrkinyt selvittämään samaa erilaisista istutuksịsta. Ruotsissa metsän boniteetti on arvosteltu $100 \mathrm{v}$. ikään päässeiden puiden »ylemmän korkeuden» (övre höjd) perusteella. Likimäärin voitaneen katsoa, että boniteettia $H \quad 100=20$ edustavat mäntymetsiköt ovat vertailukelpoisia ILvEsSALon EVT-tyypin luonnon normaaleihin mäntymetsiköihin, joissa valtapituus 100 vuoden iässä on Kainuun alueella $20.8 \mathrm{~m}$.

Valitettavasti vertailukelpoisuus ruotsalaisiin tutkimuksiin osoittautuu heikonlaiseksi puustojen ollessa Ruotsin koealoilla tiheydeltään melkoisesti erilaisia kuin Perä-Pohjolan koealoilla. Niinpä Pettersonin koealoilla on 38 v. iässä kasvanut n. 8900 puuta ha kohden ja 68 v. iässä (kuuden 5-vuosittaisen harvennuksen jälkeen) $2800-3600$ puuta, kun ILvEssalon luonnon harventamilla koealoilla $70 \mathrm{v}$. iässä on ollut vain 2100 puuta (50 v. iässä n. 3000$)$. Pettersonin aineistossa on vain yksi tuottotaulu (P 95), jossa luontainen harveneminen on määrännyt puuston kehityksen; sillä on 68 vuoden iässä ollut jälellä 4700 puuta, kasvuston ollessa siis kaksi kertaa tiheämpää kuin ILvEssaLon aineistossa. Tästä syystä on mm. keskiläpimitoissa huomattavia eroavuuksia. ANDERssovin koealojen puustotiheydet, jotka ovat määräytyneet osaksi istutustiheyden, osaksi harvennusten perusteella, ovat sitävastoin tuntuvasti pienempiä (70 vuoden iässä $1100-1300)$.

Pettersonin tutkimustulokset, jotka perustuvat verraten kaavamaiseen koesuunnitelmaan, osoittavat voimakkaiden, etenkin kaikkiin läpimittaluokkiin samassa suhteessa kohdistuvien harvennusten epäedullisuuden. Tämän vuoksi valitaan tässä tarkastettaviksi vain hänen tuottotauluissan P 7 ja P 8 esitetyt tulokset. Edellisessä tapauksessa on seurattu $5 \%$ :n alaharvennusta ja 1 $\%$ :n keskimääräisharvennusta, jälkimmäisessä $5 \%$ :n sekä ala- että keskimääräisharvennusta. Nämä prosenttiosuudet on otettu 38 vuoden iästä lähtien 5-vuosittain, joten ottoprosentti 10 vuodessa on ollut edellisessä tapauksessa 12 ja jälkimmäisessä 19. Luontainen harveneminen, joka on esittty tuottotaulussa P 95 (Petterson 1955, p. 389) on runkoluvussa ollut aluksi $13.7 \%$, mutta kiertoajan loppupuolella vain n. $7 \%$. ILvEsSALon tuottotaulukon mukaan runkoluvun itseharveneminen on ollut aluksi n. $16 \%, 120-130$ v:n iässä n. $12 \%$ kymmenvuotiskautta kohden.

Seuraavista asetelmista voidaan saada jonkinlainen kuva mainittujen, laskelmissamme vertailukohteina käytettyjen mäntykoealojen puustosta ja kuutiotuotoksesta n. 100 ja n. 130 vuoden ikään ehdittyä. Edelliseen on otettu myös CARbonnieR'in (1959) kolmen Rovaniemen-Tornion korkeudella olevan koealan arvot, joista viimeisellä on 70 vuodesta lähtien toteutettu »vahva alaharvennus», kahdella ensimmäisellä ei ole lainkaan harvennettu. 


\begin{tabular}{|c|c|c|c|c|c|c|c|c|}
\hline $\begin{array}{l}\text { Tuo } \\
\text { Yie }\end{array}$ & $\begin{array}{l}\text { ottotaulu } \\
\text { eld table }\end{array}$ & $\begin{array}{l}\text { Runko- } \\
\text { luku } \\
\text { Number } \\
\text { of trees }\end{array}$ & $\begin{array}{c}\text { Ylempi } \\
\text { korkeus } \\
\text { Upper } \\
\text { height }\end{array}$ & $\begin{array}{c}\text { Läpi- } \\
\text { mitta }^{2} \text { ) } \\
\text { Diameter } \\
1.3 \mathrm{~m}\end{array}$ & $\begin{array}{c}\text { Pohja- } \\
\text { pinta- } \\
\text { ala, } \\
\text { Area } \\
\mathrm{m}^{2}\end{array}$ & $\begin{array}{c}\text { Kuutio } \\
\text { kuoren } \\
\text { alla } \\
\text { Volume } \\
\text { k-m }\end{array}$ & $\begin{array}{c}\text { Harven- } \\
\text { nukset }^{3} \text { ) } \\
\text { Thinn- } \\
\text { ings } \\
\text { k-m }{ }^{3}\end{array}$ & $\begin{array}{c}\text { Yhteen- } \\
\text { sä kuo- } \\
\text { retta } \\
\text { Total } \\
\text { k-m }{ }^{3}\end{array}$ \\
\hline \multirow[t]{2}{*}{ ILVESSALO, } & PP, EVT ........... & 1246 & 18.7 & 21.7 & 29.2 & 225 & 105 & 330 \\
\hline & $\mathrm{K}, \ldots \ldots \ldots \ldots \ldots \ldots$ & 900 & 20.8 & 22.3 & 29.9 & 252 & 147 & 380 \\
\hline Petterson, & P $95 \ldots \ldots \ldots \ldots$ & 2652 & 19.7 & 11.8 & 28.3 & 193 & 95 & 288 \\
\hline , & P $7 \ldots \ldots \ldots \ldots \ldots$ & 1745 & 19.7 & 14.6 & 27.6 & 205 & 94 & 299 \\
\hline , & P $8 \ldots \ldots \ldots \ldots \ldots$ & 1064 & 19.7 & 16.2 & 21.6 & 160 & 130 & 290 \\
\hline ANDERSSON & $\mathrm{T} \quad 6 \ldots \ldots \ldots \ldots \ldots$ & 471 & 20.0 & 26.0 & 24.0 & 213 & 86 & 399 \\
\hline 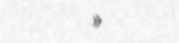 & T $7 \ldots \ldots \ldots \ldots \ldots$ & 575 & 19.4 & 24.2 & 25.0 & 212 & 124 & 336 \\
\hline CARBONNIER & $\begin{array}{l}629 \text { II itseharv. } \\
\text { natural } \\
\text { thinning }\end{array}$ & 1488 & 18.2 & 15.1 & 26.6 & 193 & 38 & 231 \\
\hline $\begin{array}{l}70 \text { v. } 613 \text { III } \\
70 \text { years }\end{array}$ & , & $4860^{\circ}$ & 14.3 & 8.8 & 29.5 & 175 & 23 & 198 \\
\hline $\begin{array}{r}628.3 \text { vahva } \\
\text { Strong }\end{array}$ & $\begin{array}{l}\text { alaharv. ............. } \\
\text { thinning }\end{array}$ & 764 & 17.2 & 15.9 & 15.1 & 105 & 90 & 195 \\
\hline 130-vuotiset & puustot $\left.^{4}\right)-130 y$ & ars old & stands & & & & & \\
\hline ILVESSALO, & $\begin{array}{l}\text { PP, EVT } \ldots \ldots \ldots \ldots \\
\text { K } \ldots \ldots \ldots \ldots \ldots \ldots\end{array}$ & $\begin{array}{l}802 \\
670\end{array}$ & $\begin{array}{l}20.3 \\
22.4\end{array}$ & $\begin{array}{l}24.9 \\
26.6\end{array}$ & $\begin{array}{l}28.7 \\
31.0\end{array}$ & $\begin{array}{l}240 \\
283\end{array}$ & $\begin{array}{l}165 \\
203\end{array}$ & $\begin{array}{l}405 \\
459\end{array}$ \\
\hline Petterson, & P $95 \ldots \ldots \ldots \ldots \ldots$ & 1656 & 23.2 & 15.3 & 30.0 & 243 & 163 & 406 \\
\hline 3 & P 7 ................ & 984 & 23.2 & 18.8 & 26.4 & 240 & 177 & 417 \\
\hline 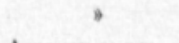 & P $8 \ldots \ldots \ldots \ldots \ldots$ & 468 & 23.2 & 22.6 & 18.2 & 163 & 225 & 388 \\
\hline ANDERSSON, & $\begin{array}{ccccc}\mathrm{T} & 6 & \ldots \ldots \ldots \ldots \\
\mathrm{T} & 7 & \ldots \ldots \ldots \ldots \ldots \ldots\end{array}$ & $\begin{array}{l}249 \\
279\end{array}$ & $\begin{array}{l}22.9 \\
22.5\end{array}$ & $\begin{array}{l}34.0 \\
31.9\end{array}$ & $\begin{array}{l}22.0 \\
21.5\end{array}$ & $\begin{array}{l}224 \\
214\end{array}$ & $\begin{array}{l}292 \\
236\end{array}$ & $\begin{array}{l}516 \\
450\end{array}$ \\
\hline
\end{tabular}

\section{Kasvatushakkuiden tuotos ja tulovaikutus}

Harvennushakkuiden vaikutusten kokeellinen tutkimus ei vielä ole johtanut täysin ristiriidattomiin tuloksiin. Eräissä pohjoismaisissa tutkimuksissa on tultu siihen tulokseen, että kuutiotuotos pienenee harvennuspoistuman suuretessa (Petterson 1937, p. 31), kun taas toisissa on havaittu voimakkaidenkin harvennusten edistäneen kuutiotuotosta (RoNGE 1928, NÄSLUND 1935, ref. Nyyssönen 1954, p. 113). Meillä on Ilvessalo (1952, p. 21-23) esittänyt vertailuja säännöllisin harvennushakkuin käsiteltyjen koekauden alussa pääasiassa $30-60$ v. ikäluokkiin kuuluvien koealametsiköiden sekä kasvu- ja tuottotaulukoiden pohjana olevien vastaavalla kehitysasteella olevien normaalien metsiköiden kokonaiskasvusta ja poistoista $21-26$ v. aikana, todeten toisessa koesarjassa $13.4 \%$ ja toisessa $3.3 \%$ eron harvennusmetsiköiden eduksi. NYYSSÖNEN (1954, p. 112-113) toteaa tutkimiensa Etelä-Suomen toistuvasti harvennettujen männiköiden antaneen eri metsätyypeissä kuutiotuotoksia, jotka eri metsätyypeissä ylittävät luonnonnormaalien metsien vastaavat tuo-

1) Pettersonin koealoilla 98 v., Anderssonin T 795 v., muuten 99-101 v.

2) Pohjapinta-alalla punnitut läpimitat; ruotsal. tutkimuksissa harvennuksen jälkeen.

3) Harvennukset (tai itseharveneminen) ko. ikään saakka.

4) Pettersonin koealoilla 128 v., Anderssonin T 7 koejäsenessä 125 v. 
tokset seuraavasti: MT $16 \mathrm{k}-\mathrm{m}^{3} /$ ha eli $3.4 \%$, VT $67 \mathrm{k}-\mathrm{m}^{3}$ eli $18.3 \%$ (ikävuosien $40-120$ välillä) ja CT $27 \mathrm{k}-\mathrm{m}^{3}$ eli $11.9 \%$ (ikävuosina $50-120$ ). Hän katsoo kuitenkin olevan uskallettua päätellä, että määnniköissä suoritetut harvennushakkaukset suurentaisivat kuutiotuotosta. VuokIlA (1956, p. 75) on puolestaan todennut $60-120$ vuoden ikään ehtineissä hoidetuissa kuusikoissa MTtyypillä $16-24 \%$ ja OMT-tyypillä jopa $40-42 \%$ :nkin suuruisen paremmuuden kokonaiskasvussa luonnonkuusikoihin verrattuna. Kuutiotuotos on $120 \mathrm{v}$. ikään ehtineissä metsiköissä edellisellä metsätyypillä $145 \mathrm{k}-\mathrm{m}^{3}$ ja jälkimmäisellä 273 k-m³ korkeampi. KALlio (1957, p. $60-66$ ) on havainnut OMT-tyypin kuusikoissa $20-30 \%$ korkeampia keskimääräisiä kuutiokasvuja luonnonnormaaleihin metsiköihin verrattuna koealoilla, joilla kasvatushakkuut ovat olleet suhteellisen voimakkaita sekä 5-20\% korkeampia, missä ne ovat olleet lievempiä. LiHTONEN (1943) suoritti tuottohakkauslaskelmaansa kehittäessään koeleimauksia eri-ikäisissä, enimmäkseen hakkuilla jo käsitellyissä metsiköissä, tavoitellen tasaisten ja hyvämuotoisten puiden puustoasennon saavuttamista harvennus- tai väljennyshakkauksilla (1943, p. 87-95). Tässä yhteydessä tutkittiin erikseen poistettavan puuston ja jäljellejäävän tuottopuuston kuutiokasvusadannes. Hän totesi, että poistopuiden kuutiokasvusadannes on säännöllisesti pienempi kuin koko metsikön, vaihdellen eri koealoilla 56-93\%:iin viimeksi mainitun kuutiokasvusadanneksesta (p. 94). Kuutiokasvusadannes on yleensä korkeimmillaan puiden vahvuusasteikon keskiluokissa (p. 95).

KALELA (1961, p. 297) esittää oppikirjassaan 110 vuotisen kokonaiskasvun luonnontilaisissa VT-männiköissä $486 \mathrm{k}-\mathrm{m}^{3}: \mathrm{ksi}$ ja hoidetuissa $545 \mathrm{k}-\mathrm{m}^{3}: \mathrm{ksi}$, eron ollessa siis $59 \mathrm{k}-\mathrm{m}^{3}$ eli $12.1 \%$. SIRÉn $(1956$, p. 45) pitää tärkeänä, että maksimaalisen kasvun mahdollistavan puuston ala- ja yläraja tarkemmin määritettäisiin, suositellen pohjapinta-alamittauksiin perustuvia, pitenevin väliajoin suoritettavia männiköiden harvennuksia.

Ruotsissa on Pettersonin lisäksi mm. Carbonnier (1959) ja Wiksten (1961) selvitelleet harvennushakkuiden tulovaikutusta pohjoisruotsalaisten koealojen perusteella. Kummankin tutkijan mukaan on vahva alaharvennus useimmissa tapauksissa lisännyt tuntuvasti nimenomaan arvotuottoa ja ns. W-arvoa (tuoton arvo kierron alkuun diskontoituna). Myöskin VuokILA (1969) on viimeaikaisissa kirjoituksissaan korostanut harvennushakkuiden arvotuottoa kohottavaa merkitystä.

Harvennusten merkitys on suurempi huonommilla kasvupaikoilla kuin hyvällä maalla (vrt. Aaltonen 1935, p. 98-99). Pohjois-Suomessa on metsien järkevä harvennuskäsittely erityisen tärkeä. ILvEsSALon (1957, p. 179-184) mukaan on mäntymetsiköiden itseharveneminen siellä aivan liian hidas ja tilanahtaus johtaa viimeistään $60-80$ vuoden iällä lopuksi kuolevien puiden ruuhkaan. "Kasvatushakkaukset näyttävät olevan pohjoisessa luonnonolosuhteiden johdosta vieläkin välttämättömämpiä kuin maassamme etelämpänä».

Suoritețut tutkimukset osoittavat yhtäpitävästi, että järkevillä harvennushakkuilla käsiteltyjen metsien kokonaiskuutiotuotos on vähintään luonnonnormaalien metsien tuotoksen tasolla, minkä lisäksi järeän arvopuuston osuus on kasvatushakkuilla käsitellyissä metsissä suurempi ja sama vuotuinen kokonaispoistuma saavutetaan pienemmällä keskimääräisellä puustopääomalla. Kun tuotos saavutetaan kiertoajan aikaisemmassa vaiheessa ja vältetään suuri osa 
luonnonpoistumasta aiheuttavista tappioista, on tarkoituksenmukaisista harvennushakkuista ilmeisesti taloudellista hyötyä, vaikka hankintataloudellisesti etenkin aikaiset ja usein toistuvat harvennukset saattavat muodostua kustannuksiltaan kalliiksi. Alempana on yritetty suorittaa numerollista arviointia harvennushakkausten tulovaikutuksista.

\section{Puutavarasta maksetut hinnat ja hankintatulot}

Metsätaloustuotteiden hinnat ovat maassamme ainakin jo 1920-luvulta lähtien vaihdelleet suhteellisesti enemmän kuin maataloustuotteiden, ja näin on erityisesti ollut maataloushintojen tultua suhteessa yleiseen hintatasoon vakaannutetuiksi 1950 -luvun alussa. Kun tutkimusalue on viime aikoihin saakka ollut ns. nollarajan tuntumassa, kantohintojen vaihtelut ovat siellä erityisen suuria, ja eri puutavaralajien hintojen suhteessa esiintyy suuria heilahteluja. Epäsuotuisan suhdanteen vallitessa, kuten esim. v. 1959, esim. mäntypinotavaran ja mm. koivuhalkojen hinnat ovat saattaneet pudota lähelle nollaa. Hyvinäkin vuosina näiden vähemmän kysyttyjen tuotteiden kantohinta on jäänyt varsin alhaiseksi maan keskitasoon verrattuna.

Kun kantohinnat suuresti vaihtelevat myös paikallisista olosuhteista riippuen ja tilastotietoja on niukasti, on taloudellisia laskelmia varten tarpeellisten arviohintojen määrittäminen erittäin vaikeaa. Kaukaiseen tulevaisuuteen tähdättäessä se on tietenkin mahdotontakin, mutta tämän puolen jätämmekin kokonaan tiettyjen olettamusten varaan $^{1}$ ).

Luonnollisinta olisi hinta-arvioissa nojautua pelkästään niihin tietoihin, joita tutkimustilojen metsänmyynneistä on saatu (vrt. p. 420). Varsinaiselta tutkimuskaudelta näitä tietoja kuitenkin on saatu vain muutamalta tilalta. Kun lisäksi myyntierät ovat olleet eri vuosina melkoisesti vaihtelevia ja puusto edustaa ilmeisesti etupäässä vanhimpia ikäluokkia, on syytä harkita, missä määrin Metsäntutkimuslaitoksen yksityismetsien kantohintoja koskevan tilaston Kainuun metsänhoitolautakunnan aluetta koskevat keskiarvot soveltuisivat joko sellaisinaan tai vertailuaineistona arvioiden pohjaksi.

\section{Puutavaran kantohinnat ja hankintapalkat}

Alueella maksetuista kantohinnoista antanevat likimääräisen kuvan Metsäntutkimuslaitoksen Kainuun metsänhoitolautakunnan piiriä koskevat tilastoluvut.

Kainuun kantohinnat ovat tämän tilaston mukaan vv. 1955/56-1963/64 olleet suhteessa maan keskihintoihin seuraavat:

1) LP-laskelmissa on hintatilanteissa (a) ja (b) käytetty vv. 1959-63 keskihintoja, hintatilanteessa (c) $30 \%$ korkeampia hintoja. 


\begin{tabular}{|c|c|c|c|c|c|c|c|c|}
\hline & \multicolumn{2}{|c|}{$\begin{array}{c}\text { Havusahapuu } \\
\text { Coniferous } \\
\text { saw logs } \\
\mathrm{mk} / \mathrm{j}^{3}\end{array}$} & \multicolumn{2}{|c|}{$\begin{array}{c}\text { Kuusipaperipuu } \\
\text { Spruce pulp } \\
\text { wood } \\
\mathrm{mk} / \mathrm{p}-\mathrm{m}^{3}\end{array}$} & \multicolumn{2}{|c|}{$\begin{array}{l}\text { Mäntypino- } \\
\text { tavara } \\
\text { Pine piled wood } \\
\mathrm{mk} / \mathrm{p}-\mathrm{m}^{3}\end{array}$} & \multicolumn{2}{|c|}{$\begin{array}{l}\text { Koivuhalko } \\
\text { Fuel wood } \\
\mathrm{mk} / \mathrm{p}-\mathrm{m}^{3}\end{array}$} \\
\hline & 1955 & 1959 & 1955 & 1959 & 1955 & 1959 & 1955 & 1959 \\
\hline & -63 & -63 & -63 & -63 & -63 & -63 & -63 & -63 \\
\hline $\begin{array}{l}\text { Kainuun mhl ............ } \\
\text { Forestry Board }\end{array}$ & $0: 63.3$ & $0: 83.6$ & $6: 14$ & $7: 63$ & $2: 24$ & $2: 54$ & $0: 86$ & $0: 84.4$ \\
\hline $\begin{array}{l}\text { Koko maa ..................... } \\
\text { Whole country }\end{array}$ & $0: 97.7$ & $1: 12.6$ & $10: 32$ & $11: 98$ & $6: 35$ & 7:05 & $2: 37$ & $2: 42.6$ \\
\hline $\begin{array}{l}\text { Edell. } \% \text { jälkimm. .... } \\
\text { Former } \% \text { of the latter }\end{array}$ & & 74 & & 63 & & 36 & & 34 \\
\hline $\begin{array}{l}\text { Suomuss. tutk. tilat } \\
\text { Suomussalmi study far }\end{array}$ & $-: 64.8$ & $0: 75.9$ & $7: 83$ & 7:69 & $2: 77$ & $2: 56$ & $(0: 88)$ & $(0: 85)$ \\
\hline
\end{tabular}

Tämän tutkimuksen tutkimustiloilla ovat kantohinnat olleet samoina jaksoina vastaavasti $0: 65 / \mathrm{j}^{3}$ ja $0: 76 / \mathrm{j}^{3}$ ja kuusi- ja mäntypinotavaralla keskimäärin $4: 67 / \mathrm{p}-\mathrm{m}^{3}$ ja $5: 29 / \mathrm{p}-\mathrm{m}^{3}$, koivuhalkojen $0: 85 / \mathrm{p}-\mathrm{m}^{3}$. Olettaen, että kuusi- ja mäntypinotavaran hintasuhde on ollut tutkimustiloilla sama kuin Kainuun alueella keskimäärin, saadaan tutkimustiloille alimmalla rivillä olevat keskiarvot.

Metsäntutkimuslaitos laskee ns. verokuutiometrin arvon hintojen keskiarvosta käyttäen ko. alueella seuraavia painoja: järeä puu 8.0 tekn. $j^{3}$, kuusipaperipuu $0.17 \mathrm{p}-\mathrm{m}^{3}$, mäntypinotavara $0.20 \mathrm{p}-\mathrm{m}^{3}$, koivuhalko $0.15 \mathrm{p}-\mathrm{m}^{3}$ ja sekahalko $0.35 \mathrm{p}-\mathrm{m}^{3}$. Kuutiometrin hinnaksi muodostuu näitä painoja käyttäen Kainuun metsänhoitolautakunnan alueella vv. 1955-63 6:69 ja vv. 1959-63 8:62. Tutkimustiloilla päädytään vastaavasti arvoihin 8:20 ja 8:10.

Laskettaessa metsähallituksen tilaston mukaan Suomussalmen hoitoalueen nettotulojäämä hakkuupoistuman kiintokuutiometriä kohden saadaan osamääräksi vuosilta 1959-63 4:92, minkä pitäisi likimäärin vastata kantohintaa, kunnanverot todennäköisesti kuitenkin siitä vähennettynä.

Taloudellisia laskelmia varten olisi tarpeen selvittää eri vahvuusluokkiin kuuluvien tukkien kuutiohintojen suhteet. Kun niistä ei paikallisia olosuhteita vastaavia tietoja ole saatavissa, käytetään laskelmissa RonKASEN (ref. HEISKANEN 1965, p. 393) laskemia suhdelukuja II laatuluokan mäntytukkien arvosta sahalla. Nämä suhdeluvut muunnettuna siten, että 8' latvaläpimitan täyttävien tukkien suhdelukua on esitetty 100:lla, esitetään alempana rinnansahaustulosten, Vuoriston aikanaan (1936, p. 121) julkaisemien, sekä vastaavien uudempien eräältä Etelä-Suomen sahalaitokselta saatujen suhdelukujen (HEIskANEN 1965 , p. 389) kanssa. Asetelmaan on vertauksen vuoksi otettu myös PohjoisRuotsia koskevia suhdelukuja vuosilta 1945/46 (Petterson 1963, p. 90), 1957/58 (Wiksten 1961, p. 28) sekä 1959/60 ja 1963/64 (Skogsstatistisk Årsbok). 
Eri läpimittaluokkiin kuuluvien mäntytukkien suhteelliset kuutioarvot - The relative cubic values of the logs of different diameter classes

\begin{tabular}{|c|c|c|c|c|c|c|c|c|c|c|}
\hline & $5^{\prime \prime}$ & $6^{\prime \prime}$ & $7^{\prime \prime}$ & $8^{\prime \prime}$ & $9^{\prime \prime}$ & $10^{\prime \prime}$ & $11^{\prime \prime}$ & $12^{\prime \prime}$ & $13^{\prime \prime}$ & $14^{\prime \prime}$ \\
\hline $\begin{array}{r}\text { VuORISTo (1936) sahaustulos .... } \\
\text { sawn product }\end{array}$ & 91 & 93 & 97 & 100 & 104 & 114 & 117 & - & - & \\
\hline Heiskanen $(1965), \quad \ldots \ldots .$. & 87 & 88 & 96 & 100 & 102 & 104 & 114 & - & - & \\
\hline $\begin{array}{l}\text { RONKANEN (1965) II lk tukit } \\
\text { sahalle tuotuna }- \text { logs } \ldots \ldots . .\end{array}$ & 74 & 89 & 96 & 100 & 14 & 111 & 122 & 126 & 127 & 126 \\
\hline Petterson, Pohjois-Ruotsi & & & & & & & & & & \\
\hline 1945/46 sahatukit - saw logs & 81 & 88 & 94 & 100 & 112 & 121 & 129 & 132 & . & \\
\hline $\begin{array}{l}\text { Wiksten, Pohjois-Ruotsi 1957/58 } \\
\text { Skogstatistisk Årsbok, }\end{array}$ & . & 91 & 89 & 100 & 109 & 132 & 138 & 141 & . & \\
\hline Pohjois-Ruotsi & - & 80 & 92 & 100 & 107 & $\left.117^{1}\right)$ & $\therefore$ & - & - & \\
\hline $1963 / 64$ & 75 & 83 & 93 & 100 & 106 & 113 & $\left.117^{2}\right)$ & . & . & \\
\hline
\end{tabular}

Suhdeluvut eivät sellaisinaan osoita kantohintojen suhteita, koska sahoille tuodun tavaran hintaan sisältyy myös hakkuu-, ajo- ja kaukokuljetuskustannuksia. Hakkuu- ja ajokustannukset on, kuten p. 377 on mainittu, laskettu vallinneiden urakkapalkkanormien mukaan. Hakkuu- ja ajopalkat tukkien kohdalta on valittu oksaisuusluokasta II ja tiheysluokasta 2; ajon kilometrikorotus on $1 \mathrm{~km}$ matkalla I lk lumitietä. Myös pinotavaran tekokustannukset on laskettu II oksaisuus- ja 2. tiheysluokan mukaan ja edellyttäen puolipuhtaaksi ristikoille tehtyä $2 \mathrm{~m}$ pituista tavaraa.

Tällä tavoin on hakkuu- ja ajopalkoiksi saatu sahatukeille ja puolipuhtaalle pinotavaralle seuraavia markkamääriä. Asetelmassa on mainittu myös niitä vastaavat mies- ja hevostuntimäärät, edellyttäen että hakkuumiehet pääsevät tavoitteeksi asetettuun 15:60 ja ajomiehet 36:- päiväansioon (1:95 ja 4:-/t).

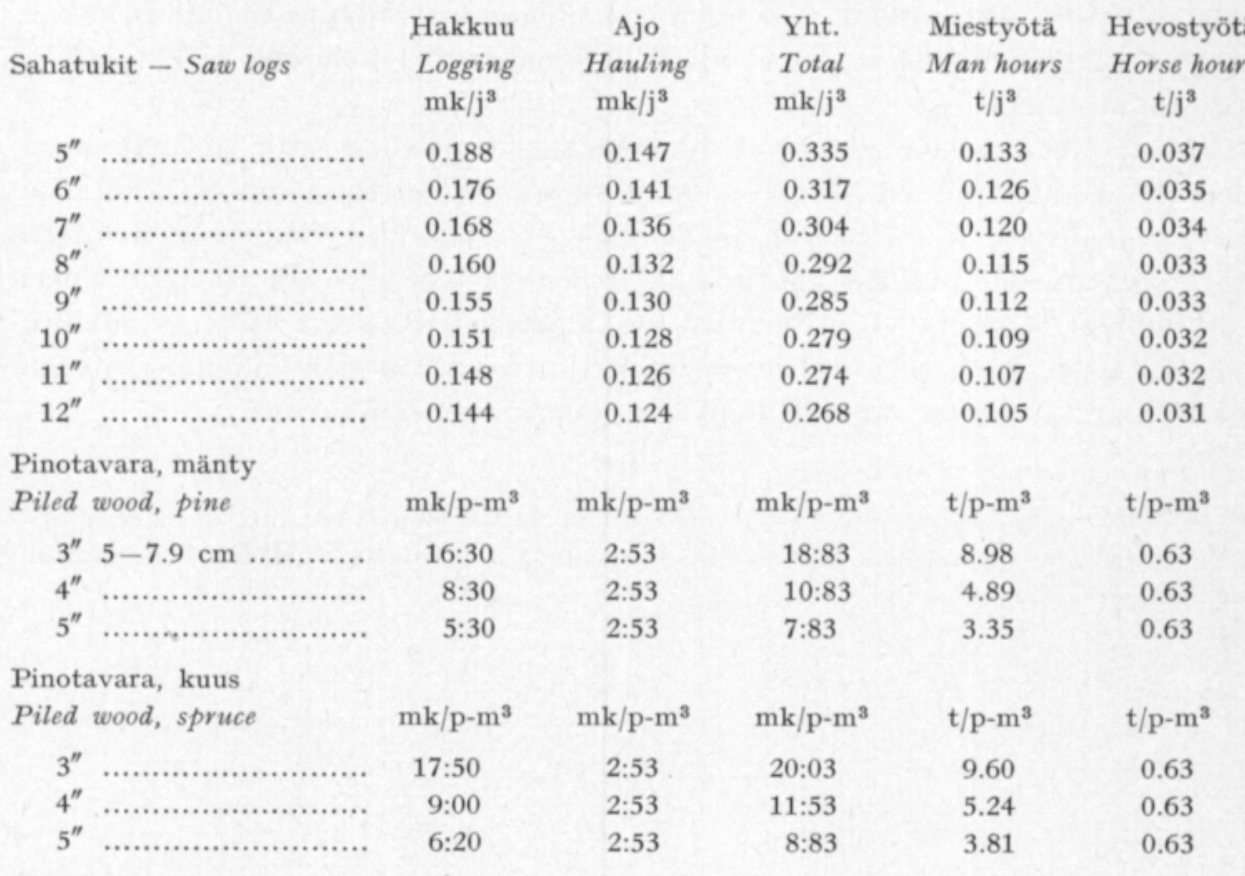
1) $>10^{\prime \prime}$
2) $>10.5^{\prime \prime}$ 
Vertailun vuoksi mainittakoon, että Pohjois-Ruotsissa Tornion-Piteån uittoalueella maksettiin hakkuukautena 1959/60 8' mäntytukeista Rkr. 2:26 ja 1963/64 2:60 (markoissa 1:40.6 ja 1:61.7) bruttohintoina tekn.j ${ }^{3}$ kohden, hakkuu- ja ajokustannusten ollessa Rkr. 0:57 ja 0:74 (mk. 0:35.4 ja 0:46) sekä yleiskustannusten Rkr. 0:19 ja 0:20 (mk. 0:11.8 ja 0:12.4) j3 kohden (Skogsstatistisk Årsbok, 1960, 1963/64). Ns. vaippa-arvoa (sahausjätteitä) sisältyi bruttotuottoon edellisen lisäksi 0:84 ja 0:99 Rkr. (0:52 ja 0:61.6 mk) tekn.j ${ }^{3}$ kohden. Kantohinnaksi muodostuu vähennyslaskun jälkeen 1:45.4 ja 1:49.3 mk. Hakkuumiehet ansaitsivat Norrbottenissa $1963 / 6477 \mathrm{Rkr}$. (47:89 mk) ja ajomiehet $121 \mathrm{Rkr}$. (75:26 mk) päivässä.

Tutkimusalueen osalta ei ole käytettävissä tietoja, joiden perusteella voitaisiin arvioida kaukokuljetusten ja hankinnan yleiskustannusten osuus sahoille tuodun tukkipuun hinnassa. Kovin suuria virheitä kantohintojen suhteen arvioinnissa tuskin kuitenkaan syntyy, jos mainittujen kustannusten kohdalta käytetään lähtökohtana keskiarvoja, joita valtionmetsien osalta on julkaistu alueittain vuosilta 1958-62 (RIIHINEN 1967, p. 214-215) ja maan keskihintojen kohdalta vuosilta 1964-66 (Heikinheimo et al. 1967 p. 33, 36). Edellisen tilaston mukaan hankintakustannukset ovat olleet Kainuussa ja PohjoisPohjanmaalla mainittuna jaksona $\mathrm{k}-\mathrm{m}^{3}$ kohden kaikkiaan 18:54 mk, josta hakkuu- ja ajokustannuksia $64 \%$ sekä välillisiä hankintakuluja $36 \%$ eli 6:67 mk. Havutukkien tehdashinnan ja kantohinnan ero on jälkimmäisen mukaan ollut keskim. 17:67 mk, mäntypaperipuun 26:- ja kuusipaperipuun 25:$\mathrm{mk} / \mathrm{k}-\mathrm{m}^{3}$; kaukokuljetus on kuusitukkien osalta maksanut v. 1965 9:- ja kuusipaperipuun osalta $10:-\mathrm{mk} / \mathrm{m}^{3}$. Ottaen huomioon, että vuoden 1965 luvut ovat inflaation vuoksi kohonneet tutkimusajankohdan tasosta, voinemme pitää 8:- mk:n välillisiä hankintakuluja $\mathrm{k}-\mathrm{m}^{3}$ kohden laskelmiimme sopivina. Olettaen, että ne voidaan tekn. $\mathrm{j}^{3}$ kohden laskea samaksi eri läpimittaluokissa, käytämme tukkien kohdalla $-: 20 \mathrm{mk} / \mathrm{j}^{3}$ ja pinotavaran kohdalla $5: 70 \mathrm{mk} / \mathrm{p}-\mathrm{m}^{3}$ kustannuslukua.

Erinäisillä perusteilla voidaan likimääräisesti arvioida, että latvaläpimitaltaan $8^{\prime \prime}$ mäntytukit edustavat ainakin suunnilleen keskimääräistä kauppaan tulevaa mäntysahatavaraa Pohjois-Suomessa ${ }^{1}$ ). Näinollen voidaan katsoa, että eri läpimittaisten tukkien kuutiojalkahinnat voidaan arvioida toisaalta alueen keskihinnan, toisaalta ylläesitettyjen keskimääräisten kantohintojen, hankintakustannusten ja sivulla 421 esitettyjen RoNKASEN suhdelukujen perusteella. Kantohinta-arvio eri läpimittaluokissa muodostuu seuraavaksi:

1) Myöhemmin selostetulla tavalla lasketut apteeraustulokset $140-160 \mathrm{v}$, ikäisistä luonnonnormaaleista männiköistä johtavat hyvin lähelle $8^{\prime \prime}$ osuviin kuutiomäärällä painotettuihin keskiarvoihin. 


$\begin{array}{lccc}\text { Hakkuu- ja } & \text { Välillinen } & \text { Tehdashinta } & \text { Kantohinta } \\ \text { ajokustann. } & \text { hankintakust. } & \text { Factory price } & \text { Stumpage price } \\ \text { Logging and } & \text { General cost } & & \\ \text { hauling } & & & \end{array}$

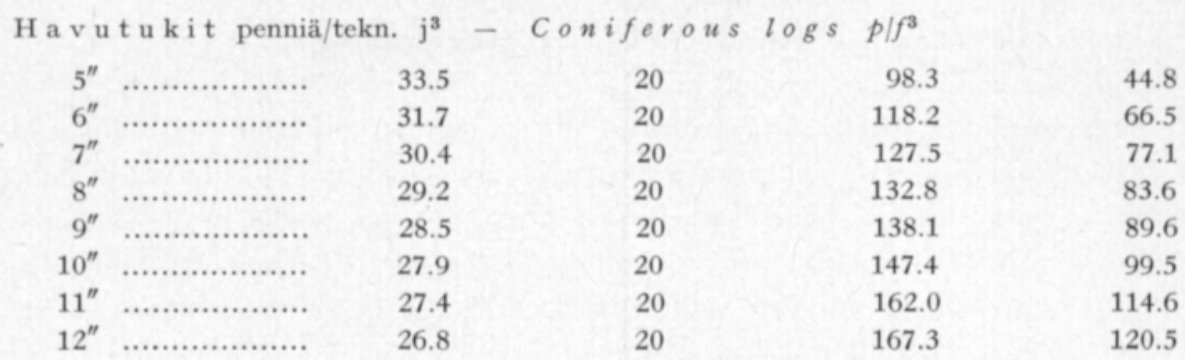

Mäntypinotavara (puolipuhd.), p-m $\mathrm{m}^{3}$ kohden - Piled wood, pine, $m k / m^{3}$

\begin{tabular}{|c|c|c|c|c|}
\hline 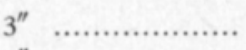 & $18: 83$ & $5: 70$ & 19:08 & - \\
\hline …………...... & $10: 83$ & $5: 70$ & $19: 08$ & $2: 55$ \\
\hline $5^{\prime \prime}$ & $7: 83$ & $5: 70$ & $19: 08$ & $5: 55$ \\
\hline
\end{tabular}

K u usipinot a vara (puolipuhd.) $\mathrm{p}-\mathrm{m}^{3}$ kohden - Piled wood, spruce

\begin{tabular}{|c|c|c|c|c|}
\hline 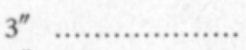 & 20:03 & $5: 70$ & 24:93 & - \\
\hline …................... & $11: 53$ & $5: 70$ & $24: 93$ & 7:70 \\
\hline $5^{\prime \prime}$ & $8: 83$ & $5: 70$ & $24: 93$ & $10: 40$ \\
\hline
\end{tabular}

\section{Puun arvotuottoa koskevat laskelmat}

Metsätaloudellisissa laskelmissa aiheuttaa ongelmia kuutiomitoissa ilmaistun kasvun vaikea yhdistettävyys myyntituloihin ja yleensä taloudelliseen tulokseen. Pelkästään hakkuusuunnitteen määrääminenkin on tehtävä, jonka teoreettiset näkökohdat ovat vielä muutaman viime vuosikymmenen aikana meilläkin olleet jatkuvan tieteellisen pohdinnan ja keskustelun kohteena (vrt. esim. Lihtonen 1943, KuUsela ja Nyyssönen 1962). Tämän kirjoittajalla ei taas toiselta puolen ole tietoa siitä, miten paikalliset metsäammattimiehet tämän osan metsätaloussuunnitelmasta yleensä tekevät.

NYYSSöNEN on eräässä tutkimuksessaan (1958) pyrkinyt määrittämään optimaalisen kiertoajan ns. rajakannattavuuden perusteella, menettelytapa, jota jo aikaisemmin on suositeltu (DUERR ja BOND 1952). Optimaalinen kiertoaika voidaankin, jos sovitaan korkoprosentista, hinnoista ja eri järeysluokkien hintasuhteista, määrittää tällä menettelytavalla, mutta vain niiden kasvu- ja tuottotaulukoiden pohjalla, jotka ovat käytettävissä. ILvEssalon uudet tuottotaulut perustuvat luonnonnormaaleihin metsiköihin, joiden voidaan katsoa syntyneen itseharvenemisen olosuhteissa. Vastaavanlaisia taulukoita kasvatushakkuilla hoidetuista metsiköistä ei tutkimusta suoritettaessa ollut Pohjois-Suomesta käytettävissä, eivätkä myöskään edellä mainitut PohjoisRuotsissa suoritetut tutkimukset ole edes vertailuaineistona olleet kovinkaan suureksi hyödyksi.

Kun asettamamme arvioimistehtävän suorittamiseksi on löydettävä edes jonkinlainen väliaikaisratkaisu, olemme käyttäneet ILvEssaLon runkoluku- 
ym. sarjoja sekä myöhemmin esitettäviä hinta- ja hintasuhdetietoja optimaalisen kiertoajan määrittämiseen itseharvenemiseen perustuvan metsätalouden puitteissa. Olemme edelleen laskeneet puun kantohintatuoton ja puunkorjuun kautta saadun työntuoton keskiarvoina kolmelle eri kiertoajalle, jotka siis muodostavat yhtä monta vaihtoehtoista tuotantoprosessia kivennäismaan kasvullisella metsämaalla.

Saadaksemme kasvatushakkuut mukaan olemme lähinnä ruotsalaisten tutkimustulosten nojalla pyrkineet määrittämään kasvatushakkuiden tulovaikutuksen täysin erillisenä hakkaussuunnitelmista. Lisäämällä tämä arvioitu tulovaikutus niihin tuottolukuihin, jotka on saatu itseharventuneista metsistä, otaksumme voivamme ainakin suunnilleen arvioida tarkoituksenmukaisesti harvennettujen metsiköiden arvotuoton.

\section{Arviot Kainuun metsätyyppien puuntuoton arvosta}

Arvioidessamme kivennäismailla kasvavan metsän arvotuottoa olemme käyttäneet kahta rinnakkaista menettelytapaa. Edellisen mukaan, jota nimitämme Tapion Taskukirjan menettelytavaksi (NyyssöneN 1965, p. 200), jaetaan eri läpimittaluokkiin kuuluvan puuston kuutiomäärä eri puutavaralajeihin puun keskiläpimittaan ja pituuteen perustuvien, mainitussa kalenterissa esitettyjen normien perusteella. Kuutiomäärät hinnoitellaan sitten, pinotavaran osalta keskihintojen mukaan, soveltamalla tukkipuun osalta HARven (1940) tutkielmassa esitettyjä eri kuutiosisältöluokkiin kuuluvien runkojen hintakerroinsarjaa, jossa $10 \mathrm{j}^{3}$ :n rungon arvoa on merkitty 100:1la. Suhdeluvut ovat vanhoja, mutta ylempänä esitetyt eri ajoilta olevat eri läpimittaisten pölkkyjen arvosuhteetkaan eivät näytä kovin voimakkaasti muuttuneen. Toisessa menettelytavassa, jota nimitämme PETTERsonin metodiksi, arvioidaan runkojen jakaantuminen tarkoituksenmukaisen pituisiksi pölkyiksi, ja nämä hinnoitellaan tukkien arvosuhdekertoimien perusteella.

Kainuun luonnonnormaaleista EVT tyyppisistä metsiköistä on tehty laskelma, jonka luvut perustuvat osaksi ILvessalon julkaisussa oleviin tietoihin eri ikäluokkien runkojen luvusta ja kuutiojakautumasta (Ilvessalo 1967, p. 32). Hinnoittelu puolestaan perustuu Kainuun metsänhoitolautakunnan keskiarvoihin vv. 1959-63. Mäntypaperipuun hinnasta on otettu kuitenkin myös korkeampi vaihtoehto (2), koska sen hinnassa on hyvin pian tutkimuskauden jälkeen tapahtunut rakenteellinen muutos. Paperipuun kiintokuutiot on muutettu pinokuutiometreiksi kertoimella 1.25, ohutpuun vastaavasti kertoimella 1.50. Ohutpuu on hinnoiteltu halkojen hintaan; hukkapuulle ei ole laskettu mitään hintaa.

Harvennushakkuiden tuotot, joskin on kysymyksessä vain itseharvennusta vastaavat puuntuotot, on erikseen arvioitu. Vertailujen helpottamiseksi esitämme tässä sekä määrä- että arvotuotot toisaalta pelkistä päätehakkuista, toisaalta oletetuista erittäin lievistä harvennushakkuista 80,100 ja 130 vuoden kiertoajalta, kaikissa tapauksissa kiertoajan vuotta kohden laskettuina. 
EVT - Kainuu (Ilvessalon perustiedot), ha kohden - per ha

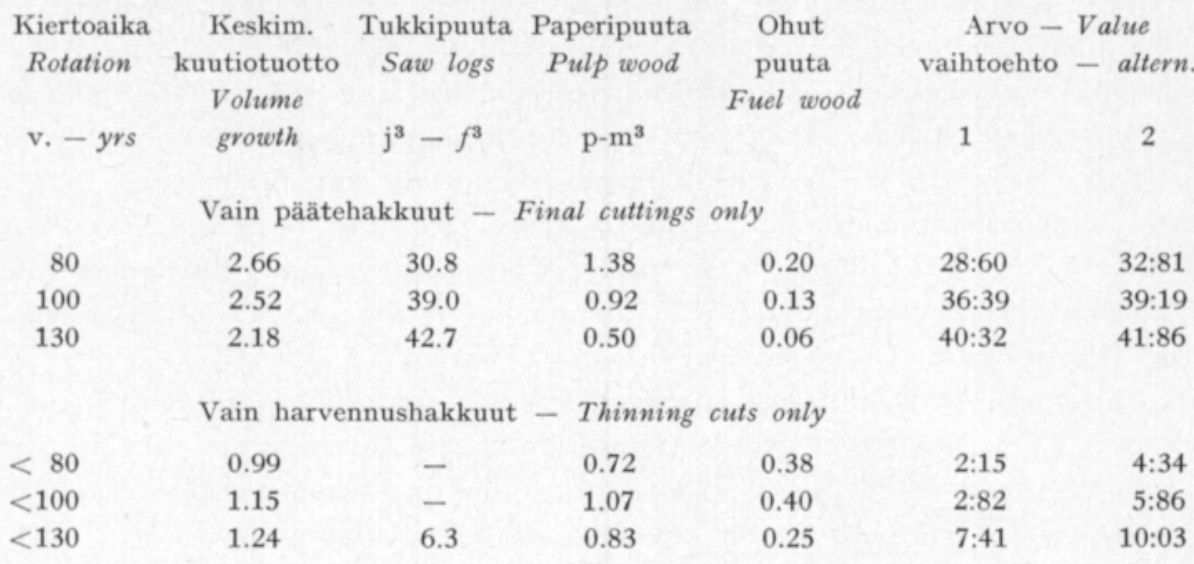

Seuraten samaa laskutapaa on selvitetty myöskin ECT-tyypin luonnonnormaalin metsikön arvotuotto. Eräillä interpoloinneilla ja suhdeluvuilla on arvioitu myös muiden kasvullisten metsätyyppien arvotuotto, ja kun vielä on tehty kussakin metsätyypissä korjaus luvulla, joka osoittaa, mikä suhde on alueellisen, valtakunnan metsien linja-arvioinnissa selvitetyn keskimääräisen kuutiokasvun ja kasvu- ja tuottotaulukkojen ilmaiseman kasvun välillä, on saatu seuraava asetelma, jonka pitäisi kuvata kasvullisen metsän keskimääräistä arvotuottoa. Metsän keskiluvut on laskettu metsäalan perusteella painoitettuina.

Arvio Suomussalmen tutkimusalueen kasvullisten metsien keskituotosta.

Estimation on the average veturn of the productive forests

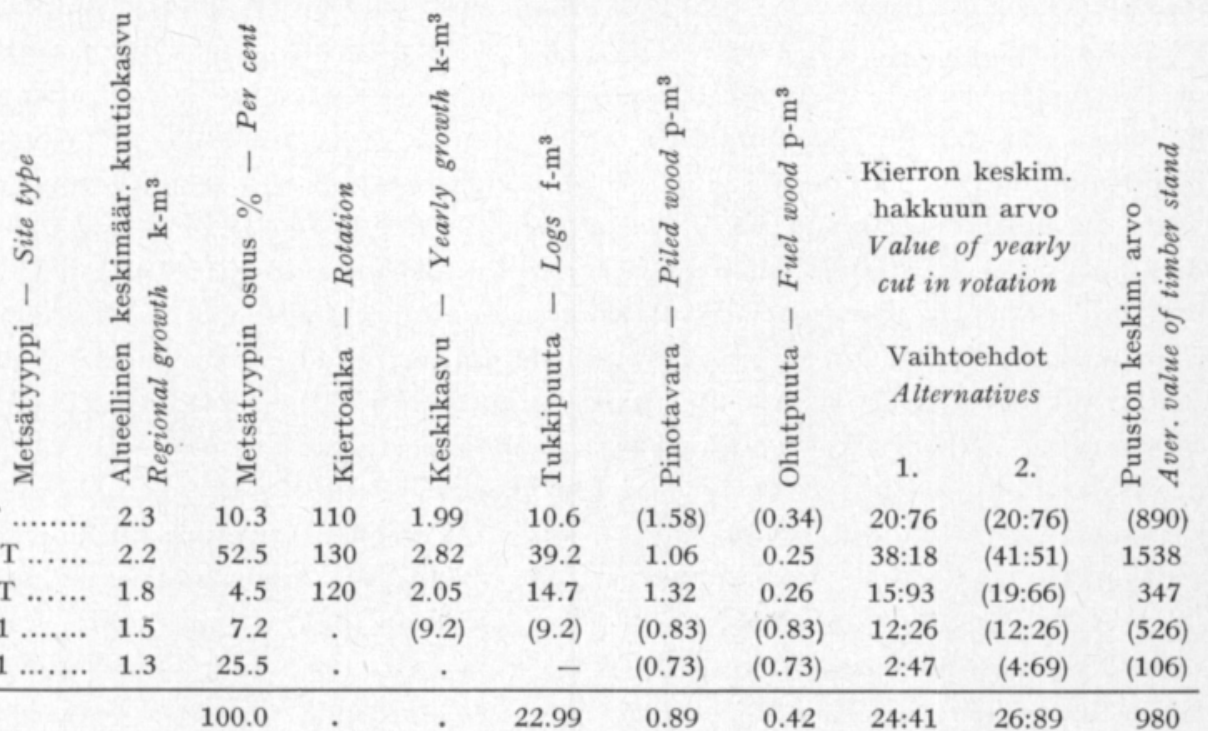


Tätä taulukkoa laadittaessa pyrittiin arvioimaan myöskin optimaalinen kiertoaika NyyssöSEN (1958) meillä tunnetuksi tekemää marginaalituottomenetelmää soveltaen. Kiertoaikaa pidennettäessä saadaan NyyssösEN mukaan optimaalinen tulos silloin, kun hakkuuajan siirtämisestä saadulle hakkuuarvon lisäykselle vielä saadaan puhtaan tuoton lisäyksen muodossa vähintään tavoitteeksi asetettu korko. Laskelmissamme asetettiin tavoitteeksi $3 \%$ :n korko, ja työkustannusten katsottiin tulleen peitetyiksi harvennushakkuista saaduilla tuotoilla. Tällöin päädyttiin EVT-tyypin maalta 130 vuoden ja ECT-tyypin maalla vastaavasti 120 vuoden kiertoaikaan. Laskelmissa käytettiin lukuja, joita ei ollut redukoitu.

Koska tuotantosuunnitelmissamme käsitellään erikseen mineraali- ja erikseen turvemaan tuottoa, ei ylläolevan asetelman keskiluvuilla ole erityisempää merkitystä. Turvemaan tuotot sellaisina, kuin ne on havaittu tutkimusaikana, ovat alhaisia. Pyrkimyksenä on kohottaa niitä keinoilla, joita voidaan pitää tähänastisen tutkimuksen perusteella varsin luotettavina, kuten erityisesti ojituksilla. Tämän tutkimuksen tullessa painovalmiiksi on uusiakin mahdollisuuksia jo löytymässä.

\section{Apteeraukseen perustuvat tuottolaskelmat}

Tutkimustyössä tunnettiin kiinnostusta myöskin muita arvotuoton määrittämisessä sovellettuja menetelmiä kohtaan. Haluttiin myös ottaa huomioon eri läpimittaluokkiin kuuluvien runkojen puutavaralajeiksi valmistamisen ja kuljetuksen erilainen työnmenekki ja siitä johtuvat erilaiset valmistus- ja kuljetuskustannukset.

Petterson $(1963$, p. 30, 254) on Pohjois-Ruotsin männiköiden arvotuottoa selvittäessään käyttänyt runkojakaantumisesta, läpimittaluokkien keskimääräisläpimitoista ja korkeuksista laatimiaan taulukoita. Hän on apteerannut luokkien keskimääräisrungot ns. ulosvetomenetelmän (utdrag-metod) mukaan, asettaen tukkien minimipituudeksi $12 \mathrm{j}$ ja lisäten pituutta siitä kunkin pölkyn osalta pisteeseen, jossa läpimitta on 0.95 kertaa läpimitta minimipituuden kohdalta. Massapuun pienimmäksi latvaläpimitaksi (kuoren alla) on asetettu 3" ja sahapuun 6". Puun korkeus kussakin läpimittaluokassa sekä kuoren vahvuus on arvioitu erityisiä kaavoja käyttäen (PETTERSon 1955, p. 153, 313, 348). Rungon muotoluku on valittu Edgrenin ja Nylinderin (1950, 56-57, vrt. myös $64-$ ) laatimasta Pohjois-Ruotsin männiköitä koskevasta taulukosta puun lasketun pituuden ja rinnanhkorkeusläpimitan (kuoren alta) perusteella. Apteerauksessa on latvusraja otettu Petrersonin (1963, p. 218-219) esittämästä taulukosta. Pölkkyjen kuutiosisältö on laskettu NäsLundin ja HAGBERGin (1952) Pohjois-Ruotsia koskevista taulukoista. Kuutiosisältö on ilmoitettu ns. lauttauskuutioina (flottningskubik), joista teknillisten tai pinokuutiometrien johtaminen käy esim. Aron (1965, p. 257, 267-268) taulukoiden avulla.

Petterson (1963, p. 295 ja seur.) on esittänyt joukon taulukoita, joissa tiettyä (yleensä 1947/48 vallinnutta) hintatasoa vastaava taloudellinen tulos on laskettu eri kiertoajoille erilaisin harvennuksin käsitellyissä metsiköissä, mm. 
Pohjois-Ruotsin männiköihin kuuluvissa. Taulukoista selviävät läpimittaluokittain saha- ja massapuun volyymit, niiden bruttoarvo, kaato-, valmistusja kuljetuskustannukset sekä niiden perustalla laskettu kantohinta-arvo sekä edelleen välillisten kustannusten hankintaan kohdistuvat osuudet. Valitettavasti työkustannuserät perustuvat vain työehtosopimusten urakkahinnoitteluun, joten niiden uudelleenarvioiminen palkkojen ja työtehon muuttuessa on vaikeata.

Tässä tutkimuksessa sovellettiin utdrag-menetelmää Kainuun EVT-tyypin tuottoarvion laatimiseksi. Laskelmat tehtiin kolmea ikävaihetta edustavasta runkojakautumasta, nim. $80 \mathrm{v} ., 100 \mathrm{v}$. ja $130 \mathrm{v}$. Oheisessa taulukossa on laskelman tulokset mm. puutavaralajien jakaantuman mukaan; siihen on myöskin otettu arvioitu miehen ja hevosen työaika sekä työkustannus. Pinotavaran kantohinnan suhteen on esitetty samat vaihtoehdot kuin Tapion taskukirjan menetelmän mukaan laadituissa arvioissa. Pinotavaran kantohintaa ei tässä laskelmassa kuitenkaan ole erilaistettu eri läpimittaluokissa käytettävän hakkuutyön määrän mukaan.

Harvennushakkuista tehtiin samassa yhteydessä arvio jonkinverran toisilla perusteilla kuin edellisissä laskelmissa. Laskelmassa lähdettiin runkoluvusta ja paksuuskasvusta. Kymmenvuotiskauden paksuuskasvun mukaan arvioitiin, miten monta puuta kunakin jaksona kussakin ikäluokassa siirtyy ylempään läpimittaluokkaan. Kun kussakin läpimittaluokassa oli näin arvioitu alemmasta luokasta tuleva lisäys ja ylempään siirtyvien aiheuttama vähennys voitiin, tehtäessä vertailuja todellisuudessa havaittuihin runkolukuihin arvioida poistuneiden erivahvuisten runkojen luku. Arvio näistä saaduista puutavaramääristä, niiden arvosta ja tarpeellisesta työmäärästä, luonnollisesti edellyttäen, että puu on otettu talteen, tehtiin samaa menetelmää noudattaen kuin päätehakkuita koskevat arviot.

Arviot on yhteenvedon tapaan esitetty alla olevassa asetelmassa. Vertailu toisella tavalla tehtyyn arvioon osoittaa, että päätehakkuiden tuottoarvot on saatu ruotsalaisella menetelmällä pienemmiksi, harvennushakkuiden arvot suuremmiksi kuin Tapion taskukirjan menetelmällä. Tuloksiin vaikuttaa melkoisesti se, lasketaanko 5 " puu massa- vai sahatavaran ryhmään. Ruotsalaisen menetelmän mukaan tehdyssä arviossa se on laskettu edelliseen, ja hinnan ollessa alhaisempi se on vaikuttanut tuloksiin.

EVT, Kainuu (Ilvessalon perustiedot) metsikön arvotuotto utdragmenetelmän mukaan laskettuna muodostuu seuraavaksi. Useimmat luvut on laskettu vuotta kohden koko kierron ajalta ${ }^{1}$ ).

1) Most figures calculated per year ander the whole rotation period. 


\begin{tabular}{|c|c|c|c|c|c|c|c|c|}
\hline $\begin{array}{l}\text { Kiertoaika } \\
\text { Rotation } \\
\text { v. yrs }\end{array}$ & $\begin{array}{l}\text { Tukkipuun } \\
\text { hinta } \mathrm{j}^{3} \\
\text { Price of } \\
\text { saw logs }\end{array}$ & $\begin{array}{l}\text { Tukki- } \\
\left.\text { puuta }^{1}\right) \mathrm{j}^{3} \\
\text { Saw } \\
\text { logs }\end{array}$ & $\begin{array}{l}\text { Paperi- } \\
\text { puuta } \\
\text { Pulp wood } \\
\text { p-m }{ }^{3}\end{array}$ & $\begin{array}{c}\text { Kantohinta- } \\
\text { tuotto } \\
\text { Stumpage } \\
\text { value } \\
\text { ha kohden/v. } \\
\text { per ha/year }\end{array}$ & \multicolumn{2}{|c|}{$\begin{array}{l}\text { Hakkuu ja ajo } \\
\text { Logging and } \\
\text { hauling }\end{array}$} & $\begin{array}{l}\text { Työn } \\
\text { arvo } \\
\text { Value of } \\
\text { labour }\end{array}$ & $\begin{array}{c}\text { Yhteensä } \\
\text { Total }\end{array}$ \\
\hline \multicolumn{9}{|c|}{ Vain päätehakkaukset - Final cuttings only } \\
\hline 80 & $-: 79,3$ & 27.4 & 1.80 & 28.51 & 11.3 & 2.1 & $27: 73$ & $56: 24$ \\
\hline 100 & $-: 82,8$ & 30.7 & 1.20 & 29:97 & 9.3 & 1.8 & 21:79 & $51: 76$ \\
\hline 130 & $-: 85,1$ & 27.5 & 0.95 & $27: 07$ & 7.9 & 1.5 & $18: 39$ & $45: 46$ \\
\hline \multicolumn{9}{|c|}{ Harvennushakkuut - Thinning cuts only } \\
\hline$>100$ & . & 12.3 & 0.34 & $10: 26$ & 2.8 & 0.6 & 7:04 & $17: 30$ \\
\hline$>130$ & $-: 79,4$ & 16.6 & 0.51 & $16: 74$ & 4.3 & 0.9 & $10: 64$ & $27: 38$ \\
\hline \multicolumn{9}{|c|}{ Pääte- ja harvennushakkuut yht. - Combined cuttings } \\
\hline 100 & & 43.0 & 1.54 & $40: 23$ & 12.1 & 2.4 & $28: 83$ & $69: 06$ \\
\hline 130 & $-: 83,0$ & 64.1 & 1.56 & $43: 81$ & 12.2 & 2.4 & $29: 03$ & $72: 84$ \\
\hline \multicolumn{9}{|c|}{ Arvioitu katetuotto $\left.{ }^{2}\right)-$ Estimated gross margin } \\
\hline 100 & . & . & . & $38: 74$ & $17: 3$ & 2.5 & $32: 26$ & 71:00 \\
\hline 130 & . & . & . & $38: 65$ & 15.5 & 2.3 & $30: 04$ & $68: 69$ \\
\hline
\end{tabular}

Uudistilan tuotantosuunnitelmassa on lähinnä apteerauksiin perustuvat tuottolaskelmien tulokset asetettu pohjaksi. Näin erityisesti päätehakkuiden kohdalta harvennushakkuiden vaatiessa oman erillisen tarkastelunsa.

\section{Harvennushakkuiden tulovaikutusta koskevia arvioita}

Kainuun kivennäismailla saatavaa arvotuottoa koskevat rinnakkaislaskelmat perustuvat kumpikin ILvEsSALon EVT-tyypin luonnonnormaalien männiköiden taulukkotietoihin. Näissä laskelmissa on myöskin itseharvennuksen kautta poistuneelle puustolle määritetty arvo, edellyttäen että se olisi otettu talteen harvennushakkuilla. Tällä kohden laskelmat kuitenkin ovat varsin epävarmoja, kun harvennuspuuston määrästä, laadusta ja korjuutyön menekistä ei ole riittävän tarkkoja tietoja.

Ilvessalo (1967, p. 17) mainitsee koealoistaan, että niillä on staimikkojen siirtyessä nuoreikkovaiheeseen» ollut $6000-7500$ puuyksilöä ha kohden, valtapituuden ollessa 6-7 m ja -läpimitan $10 \mathrm{~cm}$. Vastavanlaisia ja vielä suurempia puutiheyksiä esiintyy Pettersonin (1963), CArbonnier'in (1959) ja Wikstenin (1961) pohjoisruotsalaisilla koealoilla, joilta mainitut tutkijat ovat esittäneet tutkimustuloksia harvennushakkuiden taloudellisista tuloksista. TinHonen $(1965$, p. 32,33$)$ on selostaessaan valtakunnan metsien IV linja-arvioinnin tu-

1) Tähän luettu $6^{\prime \prime}$ ja sitä suuremmat läpimitat - Minimum diam. of logs.

2) Tässå otettu lukuun harvennustyön tulovaikutus diskontoituna (toinen arvioimistapa, vrt. p. 432). - Including the in come effect of thinnings (discounted). Estimated on the basis of Swedish studies (CARBONNIER 1959). 
loksia Pohjois-Suomen osalta todennut varttuneempien mäntytaimikoiden (kehitysluokka 3) 0.5-1.3 m korkeiden taimien keskiluvun olevan PohjoisPohjanmaalla ja Kainuussa $1770 \mathrm{kpl} / \mathrm{ha}$ ja alle $0.5 \mathrm{~m}$ korkuisten $6750 \mathrm{kpl} / \mathrm{ha}$. Yli 3000 tainta hehtaarilla on vastaavassa kehitysluokassa ollut $65 \%$ :lla ja yli 6000 tainta $42 \%$ :lla koko alasta, eri puulajien metsiköt tässä huomioon otettuina. Harventamisen tarvetta ilmeisesti esiintyy ainakin puolella metsäalasta, vaikka esim. ILvEsSALon $(1967$, p. 6) koealoilla näyttää saadun suhteellisesti tyydyttävä runkolukukehitys ja läpimittakasvu ilman varsinaisia harvennushakkuita. VUOKILA (1969) mainitsee männyn harvennusmetsiköiden pintaalaksi alueella VI (Koillisalue) 661000 ha ja kaikkien harvennusmetsiköiden vastaavasti 1082000 ha, mikä on $42 \%$ metsämaan alasta.

TIIHOSEN (1965, p. 23) taulukoista voidaan laskea, että varttuneiden taimikoiden nimellä käyvän kehitysluokan puustojen mediaani-ikä on n. 14 vuotta, nuorten harvennusmetsiköiden 38 vuotta ja varsinaisten harvennusmetsiköiden n. 64 vuotta. Ensimmäinen perustava harvennus, ellei se ole tapahtunut taimikkovaiheessa taimiston perkauksen muodossa, saattanee tapahtua nuorissa harvennusmetsiköissä, joiden keskiläpimitta on niin pieni, että puun bruttoarvo tuskin peittää korjuu- ja poiskuljetuskustannuksia. Tällaisissa tapauksissa saattaa olla edullisempaa suorittaa vain kaatovaihe, joka siirtymisineen käsittää n. 1/3 työnmenekistä. Oletamme sen tulevan suoritetuksi olosuhteissa, joissa poistettava runkoluku on 3000 , ja joissa työnmenekki voidaan painaa 1 minuuttiin vartta kohden. Työtuntimäärä hehtaaria kohden on tällöin 52, mikä ylittää esim. HUikarin (1961) ilmoittaman taimiston perkaamiseen tarvittavan työaikamäärän (4 työpäivää).

Jos harvennuksen tarvetta esiintyy $65 \%$ :lla kehitysluokan metsäalasta, joka puolestaan TirHosen lukujen perusteella arvioituna (jättämällä pois yli 130 vuotiset ja vajatuottoista puustoa käsittävät alat, olisi n. $17 \%$ säännöllisen kierron metsäalasta, tässä ensimmäisessä raivausluontoisssa harvennuksessa vuosittain läpikäytävä ala olisi 100 metsäalan hehtaaria kohden $\frac{0.65 \times 17}{25}$ eli 0.44 ha. (Puuston on laskettu viipyvän neljännessä kehitysluokassa 25 vuotta). Työtunteja tarvittaisiin siten 100 hehtaarin alalla $33 \mathrm{t}$. eli hehtaaria kohden $0.33 \mathrm{t}$.

Harvennushakkuiden tulovaikutus, erityisesti perheviljelmän haltijan kannalta arvosteltuna, syntyy seuraavista tekijöistä.

Voidaan välttää arvohäiriöitä, jotka johtuvat luonnonpoistuman hukkaan menemisestä. (Edellä esitetyissä laskelmissa on luonnonpoistumaa vastaava arvo otettu huomioon.)

Etenkin myöhemmissä harvennuksissa saadaan, ellei kantohinta-, niin ainakin työtuloa, joka saattaa nostaa tilan katetuottoa siinäkin tapauksessa, ettei työlle saada yleistä palkkatasoa vastaavaa hintaa. Viljelijän kannalta tällä mahdollisuudella on merkitystä silloin, kun vaihtoehtoista ansiomahdollisuutta ei ole.

Kysymys siitä, mistä alkaen harvennushakkuut ovat välitöntä nettotuloa tuottavia, on tärkeä mutta varsin vähän selvitetty. Pelkästään palkkatyövoimaa käyttävä metsänomistaja arvostelee sitä lähinnä kantohintatulon perus- 
teella. Itse työtä tekevä metsänomistaja laskee, jääkö hänen työlleen korvaus mikä vastaa vaihtoehtoisia ansiomahdollisuuksia.

Pettersovin (1963, p. 318) taulukoista voidaan laskea, että esim. koesuunnitelman P 8 mukainen harvennus (n. $19 \%$ ala- ja keskimääräisharvennus 10 v.) on tuottanut suoranaisia kustannuksia (hakkuu, teko, ajo ja lauttaus) vastaavan bruttotuoton 60 vuotisista puustoista lähtien. 38 vuotisissa puustoissa on lauttauskustannusten lisäksi voitu peittää vajaa $60 \%, 48$ vuotisissa n. $80 \%$ ja 58 vuotisissa n. $96 \%$ yleisen palkkatason mukaisista työkustannuksista.

Nämä suhteet riippuvat tietenkin puun hinnoista, palkoista ja eri puutavaralajien korjuu- ja kuljetustyön määrästä. Kuten seuraavasta asetelmasta nähdään työnmenekki kuutiota kohden kasvaa melkoisesti pienempiin läpimittoihin siirryttäessä. VUORIsTo $(1937$, p. $39,49,66,92)$ on esittänyt kaavoja kuusija mäntypinotavaran valmistuksen ajankäytöstä, joiden perusteella voi laskea, että läpimitaltaan $5-7.5 \mathrm{~cm}$ tai $7.5-10 \mathrm{~cm}$ vahvuisen mäntypaperipuun valmistuksen eri työvaiheisiin tarvitaan työaikaa seuraavasti:

\begin{tabular}{|c|c|c|}
\hline \multirow[b]{2}{*}{ 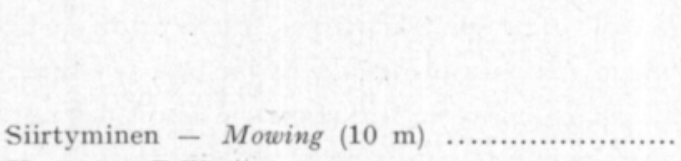 } & \multicolumn{2}{|c|}{$\begin{array}{l}\text { Työaikaa puuta kohden } \\
\text { Work time per tree, min. }\end{array}$} \\
\hline & 0.91 & 0.91 \\
\hline 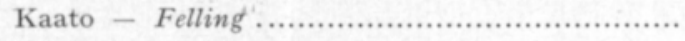 & 0.33 & 0.45 \\
\hline Karsinta - Pruning .................................... & 0.22 & 0.38 \\
\hline 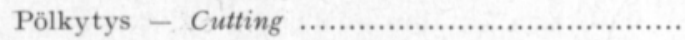 & 1.17 & 1.56 \\
\hline \multirow[t]{2}{*}{ 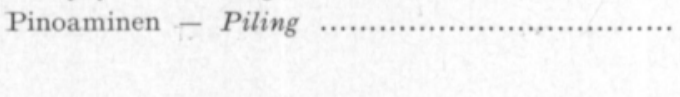 } & 0.30 & 0.94 \\
\hline & 2.93 & 4.24, \\
\hline Rungon kuutio $\mathrm{j}^{3}-$ Volume & 0.42 & 1.13 \\
\hline $\mathrm{jm} \mathrm{p}-\mathrm{m}^{3}$ kohden - Length .... & 240 & 120 \\
\hline P-m ${ }^{3}$ kohden työtä, $\mathrm{t}-$ Work hrs $/ p-m^{3} \ldots \ldots \ldots$ & 5.33 & 1.47 \\
\hline
\end{tabular}

Laskettaessa taas ajokustannuksesta $1.8-2 \mathrm{~km}$ matkalta, jossa pohjamaksu (II tieluokka, 4. tiheysluokka) on $2: 28$ ja km-korotus $-: 77 / \mathrm{p}-\mathrm{m}^{3}$, tullaan tavoitetuntipalkalla jaettuna 0.68 tuntiin $\mathrm{p}-\mathrm{m}^{3}$ kohden. MAKкоsen (1967) huomattavasti uudemmissa tutkimuksissa työaikaa on $5-8 \mathrm{~cm}$ paperipuun valmistukseen käytetty melkoisesti enemmän.

Selvitettäessä harvennushakkausten tulovaikutusta sekä välittömästi saatavien èttä tulevien tulojen osalta on sekä CARBONNIERin että WIKSTENin tutkimustuloksista merkittävää hyö̀tyä. Edellisen pohjana oli 9 koesarjaa suunnilleen Tornion-Rovaniemen leveysasteilla (yleensä 75-190 m, kahdessa tapauksessa $300-400 \mathrm{~m}$ korkeudella), ja niissä oli vertailtavana koealoja, joissa 5874 vuotisissa puustoissa oli suoritettu kolmea eri voimakkuusastetta vastaava viisivưosittainen alaharvennus; yhdessä tapauksessa latvusharvennus. Tutkimusselostuksesta selviävät $\mathrm{mm}$. poistettujen puiden lukumäärät, volyymit ja keskiläpimitat sekä raha-arvot kahden hintaporrastusvaihtoehdon mukaan.

Tarkasteltaessa CARBonnIERin koealojen harvennuspuuston keskiläpimittoja huomataan, että ne aina 80 vuoden ikään saakka miltei säännöllisesti jäävät alle $10 \mathrm{~cm}$, mikä vahvuusluokka tuskin antaa mitään kantohintatuloa. Sitävastoin voitaneen katsoa, että 80 ja 100 vuoden välillä tapahtuneet harvennushakkuut, joissa läpimitat asettuvat eräin poikkeuksin rajoihin $10-18 \mathrm{~cm}$, 
tuottavat täyden työtulon lisäksi myös kantohintaa. - Jätettäessä yksi sekapuustoa käsittävä koesarja pois, todetaan että harvennuksen kolmessa eri vaiheessa poistettiin puustoa keskimäärin seuraavat määrät, mitkä omien laskelmiemme mukaan vaativat ihmistyötä ha kohden seuraavat tuntimäärät:

Harvennukset - Thinnings Puuston ikä Poisto - Removal Työmäärä mt Age of stand Work, manhours

1. vaihe (raivausvaihe - only removal) ......... 60 $4300 \mathrm{kpl}-$ pieces 71.7

2. (vain työtuloa - only labour income) $70-85$ $\left(42.2 \mathrm{k}-\mathrm{m}^{3}\right)$

3. (työ- ja kantohintatuloa) labour income and stumpage price) ..... $85-100$ $41.2 \mathrm{k}-\mathrm{m}^{3}$ 463.5

$62.5 \mathrm{k}-\mathrm{m}^{3}$ 261.6 796.8

Suomussalmen kantohintoja ja palkkatasoa käyttäen saataisiin kantohintatuloksi 3. vaiheesta 433 : - ja työtuloksi 2 . vaiheesta 558 : - , 3. vaiheesta 489:eli yhteensä 1047:- Hevostunteja tarvitaan 65.3, arvoltaan edellisen lisäksi 176:-

Carbonnierin, samoinkuin Pettersonin ja Wikstenin tutkimuksissa on harvennushakkuiden tulovaikutusta pyritty selvittämään ns. W-arvojen (myös B'-arvojen) perusteella. Wikstenin koealat, jotka olivat osaksi läntisessä Norrlannissa, osaksi Jämtlannissa, olivat kuitenkin boniteetiltaan paremmilla mailla kuin Kainuun EVT-männiköt, joten tyydymme toteamaan, että ne osoittavat harvennusten tulovaikutuksen vielä edullisemmaksi kuin CARBONNIERin kokeet.

W-arvoissa on metsiköiden syntyhetkeen diskontoitu nettotuotot kiertoaikana saaduista ja tavallisesti myös myöhempien kiertoaikojen hakkaustuloista (joiden merkitys kuitenkin tavallisten korkokantojen vallitessa on häviävän pieni). B'-arvoissa on nuorennosten perustamiskustannukset vähennetty. Veroja ei yleensä ole sisällytetty kustannuksiin.

W- ja B'-arvot eivät sellaisinaan anna havainnollista kuvaa siitä, miten harvennustyö kannattaa viljelijälle. Se lisätulo, joka on odotettavissa harvennusten seurauksena, olisi havainnollisuuden saavuttamiseksi diskontoitava harvennusajankohtaan. Kun eri harvennusvaiheiden vaikutusta on tietenkin mahdoton erottaa, riittää kun diskontointi suoritetaan jollain tavoin painótettuun keskimääräiseen harvennusajankohtaan.

Keskimääräistä harvennusajankohtaa arvioitaessa on paikallaan pitäytyä ylempänä mainittuihin harvennustyön ajoituksiin ja tuntimääriin. Tuntimää-

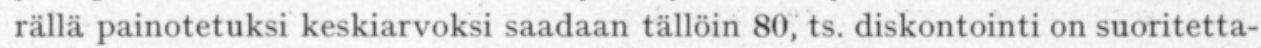
va puuston 80 ikävuoteen.

W-arvot pienenevät siirryttäessä korkeampaan korkokantaan, ja lyhyemmät kiertoajat ja voimakkaammat harvennusprosentit osoittautuvat edullisemmiksi. Tavallisten lainakorkojen soveltaminen olosuhteissa, joissa kaikki nimellishinnat jatkuvasti kohoavat ei kuitenkaan ole perusteltavissa, ellei myös tulevaisuudessa saatavaa tuloa arvioida vastaavasti korkeampien hintojen mukaan. 
Käytämme tässä tutkimuksessa korkoprosenttia 3, joka 1960-luvun kehityksen mukaan likipitäen jää nettokoroksi lainoista, joita ei ole sidottu indeksiin.

Petterson (1963, p. 450-453) on esittänyt W- ja B'-arvot eri korkoprosentein ja eri menekkiolosuhteiden mukaan sarjasta, jossa alaharvennusprosentti on pysyvästi sama, 5, kun taas keskimääräisharvennus vaihtelee 1-15. Keskimääräisiä menekkiolosuhteita ja $3 \%$ korkokantaa sovellettaessa ja nuorennusajan ollessa 0 v. W-arvo nousee $136 \mathrm{kr}$ :sta $217 \mathrm{kr}$ :n harvennusprosentin noustessa, ollen suurin $15 \%$ :n keskimääräisharvennuksessa. B'-arvo on vastaavasti noussut $32 \mathrm{kr}: s t a 111 \mathrm{kr}: \mathrm{n}$. Lisätyllä harvennuksella on W-arvoa siis kohotettu aina $60 \%$, B'-arvoa jopa lähes 4-kertaisesti.

CARBONnIERin 7 koesarjassa on itseharvennus antanut W-arvoksi keskim. 257: - kr, vahva alaharvennus $333:-\mathrm{kr}$., ja erittäin vahva alaharvennus (4 tapausta) $263:-$. Jos otetaan huomioon vain sarjat, joissa erittäin vahva alaharvennus on mukana, ovat W-arvot vastaavassa järjestyksessä 145:-, 195:ja 263: - kr. Viimeksimainitussa tapauksessa suhdeluvut arvotuottojen välillä ovat 100,134 ja 181 .

Wikstenin ensimmäisessä koesarjassa (1961, p. 45) W-arvot ovat saman korkokannan vallitessa itseharventuneella koealalla 487:- kr., lievällä alaharvennuksella käsitellyllä 682:-, keskivahvalla $716:-$ ja vahvalla alaharvennuksella käsitellyllä 765:-, suhdeluvut samassa järjestyksessä siis 100, 140, 147 ja 157. Toisessa koesarjassa W-arvo itseharventuneella alalla oli vain 280:-, vahvassa latvusharvennuksessa 446 : - ja vahvassa alaharvennuksessa 566:- , suhdeluvut siis 100,159 ja 202.

Jos Kainuun arvion ohjenuorana pidetään lähinnä CARBonnIERin koesarjoja, on huomattava, että Ilvessalon koealojen puusto ei ole ollut läheskään niin tiheä kuin edellämainittujen sarjojen puusto. Sen vuoksi ei voitane odottaa yhtä suurta suhteellista lisäystä arvotuotossa harvennuksia toimeenpantaessa. Toisaalta huomataan kuitenkin, että erittäin vahva alaharvennus on vertailukelpoisilla koealoilla antanut tuntuvasti (yli $30 \%$ ) korkeampia W-arvoja kuin vahva alaharvennus. 100 vuoden iässä on runkoluku näillä koealoilla ollut 720 , kun se Ilvessalon koealoilla on ollut 900 ja itseharvennuksen alaisilla n. 2900.

Ei liene siten mitenkään liioiteltua, jos arvioimme arvotuoton kohoavan n. 30 prosentilla harvennusten vuoksi. Ilvessalon päätehakkauksissa 100 vuòden iässä on arvotuotoksi saatu $2960:-$ ja $30 \%$ tästä on $888:-$. Jos diskontoimme tuotonlisäyksen 80 . ikävuoteen $3 \%$ mukaan saamme $44:-$, mikä siis muodostuu harvennukseen käytetyn työn lisäkorvaukseksi sivulla 431 mainitun työtulon lisäksi. Yhteensä työn katetuotto harvennuksesta on siis varovaisen arvion mukaan 1519:- eli n. 1:90 t kohden.

LP-taulukoissa on harvennustulo yhdistetty päätehakkauksesta saatavan kantoraha- ja työtulon kanssa kierron aikana hehtaaria kohden vuodessa saatavaksi katetuotoksi (vrt. asetelma p. 428). Samoin on harvennusten ja päätehakkausten työnmenekki yhdistetty merkinnällä PT varustetuissa tapauksissa. Pelkistä päätehakkauksista saatu tuotto ja niihin käytetty työmäärä on saanut merkinnän P. Esim. P 80 merkitsee 80 vuoden kierron päätehakkuita. 


\section{Turvemaan metsien ojituksen tulovaikutus}

Kuten tutkimusalueen maavarojen kuvauksesta (edellä p. 347) käy ilmi, suurin osa maa-alasta koostuu turvemaista, jotka osaksi ovat heikonpuoleista metsää kasvavia korpia ja rämeitä, joiden vuotuinen puuntuotos on $1.3-1.5 \mathrm{k}-\mathrm{m}^{3}$, ja puusto n. $60-70 \mathrm{k}-\mathrm{m}^{3}$, osaksi ns. kitumaita, joiden puusto on korkeintaan $15 \mathrm{k}-\mathrm{m}^{3}$ ja vuotuinen kasvu $0.5 \mathrm{k}-\mathrm{m}^{3}$ hehtaaria kohden (mm. varsinaiset sararämeet ja lettorämeet), osaksi täysin puuttomia alueita, kuten ruohoiset sararämeet ja nevat (rvt. Heikurainen 1961, p. 17-46). Kaikki nämä alat ovat sellaisinaan Kainuun hintasuhteissa arvotuoton kannalta merkityksettömiä.

Sitävastoin ne voidaan ojituksilla saada tuottaviksi, ja etenkin tapauksissa, joissa edes jonkinverran puustoa on olemassa, saada arvotuottoa vieläpä ennen normaalin kiertoajan täyttymistä. Tässä on laskettu HEIKURAISEN et al. (1965) tutkimuksen lukuja käyttäen kitukasvuista puustoa käsittävän suotyypin (VLR) ojitettuna tuottaman poistuman $(60-90$ v. välillä) raha-arvo käyttäen hintaa 8:60, mikä vastaa verokuutiometrin rakenteen perusteella arvioitua keskihintaa k-m³:lle (vrt. p. 353). Tällöin on päädytty hakkuutuottoon, joka on n. 1470: - ja odotettavissa n. 70-90 vuoden kuluttua. Ojitushetkeen diskontattuna $3 \%$ mukaan tämä tulo on $110-180 \mathrm{mk}$, keskim. 149:-

Ojittaminen voi tapahtua lapiotyönä (n. 20 työpäivää eli 200 työtuntia ha kohden) tai pääomaa käyttämällä (kaivinkone, n. 70:- mk/ha). Kantohintatuoton lisäksi saadaan tulevaisuudessa työtuloa: hakkuut ja ajot vaativat $\mathrm{n}$. 700 työtuntia, joista vuoden 1961 palkkatariffien mukaan saadaan 1400:- . Kustannuksiin ei lueta veroja mutta sensijaan kyllä ojien kunnossapitokustannukset (nykyhetkeen diskontattuna 25:-, taimikon perkaus (n. 20 v. kuluttua) vastaavasti $30:-$ ja ns. sekalaiset kustannukset (mm. palovakuutus) yht. 8:- Yhteensä siis $63:-$.

Ojitus aiheuttaa 1. kiertoajan (90 v.) kuluessa keskim. 7.8 miestunnin ja 1.2 hevostunnin käytön (30 viimeisenä vuotena keskim. 23.4 ja 3.6 t/ha).

Katetuotto koko kierrosta on edellisen huomioon ottaen seuraava (Gross margin of the 90 years rotation of peat land forest):

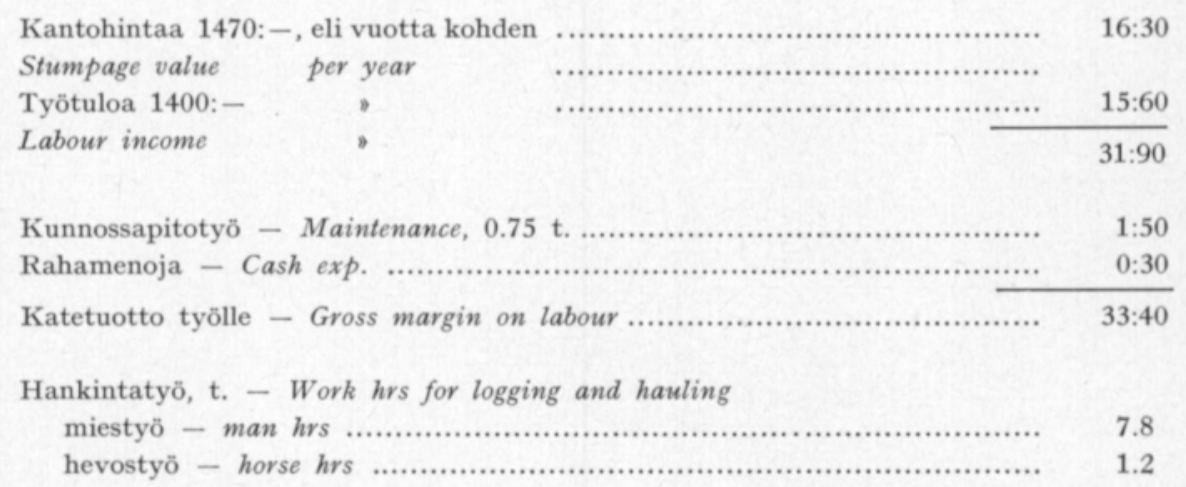

Edellä esitettyjä lukuja on käytetty laskelmissa, jotka koskevat turvemaiden metsien arvotuottoa kuntoonsaatettuina. 
Ojitustyön tulovaikutusta arvioitaessa on toisaalta laskettu katetuotto sille työlle, joka tehdään itse ojituksien suorittamisen yhteydessä. Tässä esitetään vaihtoehtoina lapio- ja konetyönä suoritetut ojitukset.

1. Ojitus lapiotyönä - Peat draining as hand work

Kantohintatulon diskontoitu arvo - Discounted stumpage value

Kunnossapitokust. diskontoitu arvo - Discounted value of maintenance ......... $63:-$

Katetuotto työlle - Gross margin on labour ............................. $86:-$

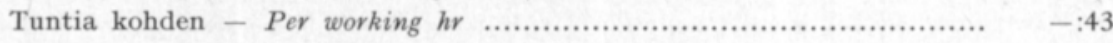

2. Ojitus konetyönä - Peat draining as machine work

Kantohintatulon diskontoitu arvo - Discounted stumpage value

Kunnossapitokustannusten diskontoitu arvo - Discounted valme maintenance 63:-

Konetyön hinta - Cash expenses of machine work

Katetuotto viljelijälle - Gross margin

Edellisestä selviää, että lapiotyönä tehdystä ojituksesta saatava tulo nykyhetkeen diskontoituna antaa varsin vaatimattoman korvauksen työtuntia kohden. Pääomanpuutetta potevalla ja vailla muita vaihtoehtoisia työtilaisuuksia olevalle viljelijälle sekin saattaa olla hyväksyttävä työvoiman käyttötilaisuus, etenkin milloin puun arvon nousu antaa toiveita laskettua korkeammasta tulosta. 


\section{Uudistilan edullisin tuotantosuunta}

Tämän tutkimuksen tavoitteeksi on asetettu sellaisen maatilataloudellisen tuotantoyhdistelmän löytäminen, joka Kainuun olosuhteissa antaa mahdollisimman korkean katetuoton yhden perheen viljelmän kiinteistöön sijoitetulle pääomalle ja säännölliselle työvoimalle (vrt. aikaisemmin p. 355). Tätä yhdistelmää haettaessa joudutaan määräämään ensiksikin maan maataloudellisen ja metsätaloudellisen käytön optimaalinen suhde sekä edelleen erilaisten mahdollisten tuotannollisten toimintojen mukaan ottaminen ja laajuus, joihin kunkin tuotantotoiminnan sekä tekniset että taloudelliset edellytykset, viimeksi mainituista erityisesti tuotteista saatavat hinnat ovat vaikuttamassa. Kaikki tämä voidaan toteuttaa tarkoituksenmukaisesti suunnitellun LP-ohjelman puitteissa.

Erityisen ongelman muodostaa, kuten aikaisemmin on eri yhteyksissä todettu, uudisviljelmän täyteen tuotantokuntoon saattamisen vaatima pitkä, monien metsätaloudellisten uudistusten kohdalta suorastaan ylipitkä aika. Näihin käytetyt toiminnot saattavat todellisuudessa olla tuloa tuottavia, mutta tulo toteutuu vasta tulevaisuudessa. Uudisviljelijä joutuu jakamaan työaikansa välittömästi tuloa tuottavien toimintojen, joille hän luonnollisista syistä yleensä antaa etusijan, ja pitemmällä tulevaisuudessa tuloa tuottavien toimintojen välillä. Maatilataloudellisten toimintojen biologisiin kasvuilmiöihin pakosta liittyvä vuodenajoittain vaihtuva luonne puolestaan vaatii korkean työllisyysasteen saavuttamiseksi monenlaisten toimintojen yhdistelyä.

Laaditussa tuotantosuunnitelmassa on asian selventämiseksi otettu huomioon eräitä sellaisia metsätaloudellisia toimintoja, jotka antavat tuloa vasta tulevaisuudessa. Niistä odotettavissa oleva tulo on diskontoitu nykyhetkeen, ja tämä diskontoitu tulo on sisällytetty katetuottoon.

\section{Tuotantoprosessit}

Maataloudellisista tuotantoprosesseista on tässä tuotantosuunnitelmassa otettu mukaan ensiksikin maidontuotanto, joka on suunniteltu turvemailla, harjoitettavien tarkoițuksenmukaisimmiksi osoittautuneiden nurmenviljelyprosessien hyväksikäyttöä silmällä pitäen. Maidontuotannon biologis-teknisiin edellytyksiin kuuluu saavutettava tuotantotaso ja tuotannon kausijakaantuma, joissa kummassakin eläinaineksen perinnöllisillä ominaisuuksilla saattaa olla jopa ratkaiseva vaikutus. Tässä on katsottu tarpeelliseksi esittää tuotanto- 
potentiaalista kolme vaihtoehtoa, vastaten vuosituotantoja 2800,3200 ja 3600 kg. Nykyoloissa voitaneen tosin korkeintakin näistä pitää helposti ylitettävänä.

Näiden maidontuotantoprosessien ohella on naudanlihan tuotannosta esitetty kolme vaihtoehtoa, minkä lisäksi sianlihan ja lampaanlihan tuotannot muodostavat omat prosessinsa. Maidon- ja naudanlihan tuotannon välillä on komplementaarinen, toisiaan täydentävä suhde, joka ohjelmassa on voitu asettaa rajoittavaksi tekijäksi. Sikäli kuin näin on tehty, on katsottu, että viljelmät ovat mahdollisimman omavaraisia esim. vasikoiden ja kuoritun maidon hankkimisessa. Todellisuudessahan viljelmillä on vaihtaessaan välituotteita mahdollisuuksia erikoistumiseen joko pelkän maidon- tai pelkän lihantuotannon suuntaan, ja ensimmäisissä aggregoiduissa ohjelmamalleissa tällainen valinta on myös tehty mahdolliseksi. Sianlihan ja maidontuotannon komplementaarisuus ilmenee lähinnä kuoritun maidon hyväksikäytössä, kun taas lampaanlihan tuotanto on katsottu toisista kotieläintuotannonhaaroista riippumattomaksi tuotantoprosessiksi.

Ohranviljely voidaan katsoa itsenäiseksi tuotantoprosessiksi, joka myy tuotteitansa kotieläintaloudelle tai markkinoille vallitsevan hintatason mukaan. Näin meneteltäessä osoittautui, ehkä riippuen myös liian edullisiksi arvioiduista panos-tuotoskertoimista, että traktoritekniikan vallitessa tämä tuotanto laajenisi uudisviljelyksillä markkinatuotannoksi epärealistisissa suhteissa. Kun Pohjois-Suomessa ei missään tapauksessa liene mahdollisuuksia tuottaa korkeita laatuvaatimuksia vastaavaa viljaa etelään vietäväksi, on viimeisissä disaggregoiduissa malleissa ohranviljely sidottu samoinkuin nurmenviljelykin tuotteita jalostavaan kotieläintalouteen. Toisaalta on kotieläintaloudelle »järjestetty" mahdollisuus ostaa viljaa, tosin korkeammilla hinnoilla myöskin tilan ulkopuolelta; asiaintila jota voidaan kysymyksesä olevien hallanarkojen alueiden olosuhteissa pitää luonnollisena.

Perunanviljely on myöskin alueen olosuhteissa katsottu ensi sijassa rehua tuottavaksi tuotantoprosessiksi. Tosin on pidetty luonnollisena, että viljelijöiden kannattaa itse tuottaa kotitalouksiensa tarvitsema perunamäärä, jolle myös vähittäishinnan mukaan hinnoitettuna muodostuu melko korkea katetuotto.

Metsätalouden tuotantoprosessit muodostuvat ensinnäkin kolmesta kiertoajan pituuden suhteen erilaisesta vaihtoehdosta mäntypuun tuottamiseen ilman harvennushakkuuta EVT-tyyppisellä mineraalimaalla $(80 \mathrm{P}, 100 \mathrm{P}$ ja $130 \mathrm{P})$, sekä myös mäntypuun tuottamiseen ojitetulla kangaskorpityyppisellä turvemaalla. Viimeksimainitun tuotantomuodon edellytetään kehittyvän lopulliseen hakkuukypsyyteen vasta 90 vuoden pituisen ajan kuluessa.

Koska Kainuuta koskevaan aineistoon ei sisälly tietoja kasvatushakkuilla käsitellyistä koealoista, ja kasvatushakkuiden tulovaikutuksia on tämän tutkimuksen kokonaisuutta silmälläpitäen kuitenkin pidetty tärkeinä, on tätä tulovaikutusta pyritty arvioiman erillisenä lähinnä pohjoisruotsalaisten vertailutietojen pohjalta. Täten on toivottavasti ainakin tulovaikutuksen suuruusluokka voitu saada selville. Ensimmäisissä LP-malleissa on kasvatushakkuita käsitelty arvioimalla hakkuunalaisilla metsähehtaareilla saatava diskontoitu lisätulo, samalla kun panoksena esiintyy käytetty ihmistyö. Tästä luovuttiin kuitenkin lopullisessa mallissa, jossa kasvatushakkuiden erillisesti arvioitu 
diskontoitu tulo lisättiin niihin kantohinta- ja työtuloihin, jotka arvioitiin saaduksi kasvatushakkuita vailla olevassa hoitomenetelmässä kunakin ajankohtana. Tällä perusteella muodostettiin kaksi uutta mäntypuun tuotantoprosessia, 100 ja 130 vuoden kiertoaikaa silmälläpitäen (100 PH ja $130 \mathrm{PH})$.

Edellämainitut tuotantoprosessit on katsottu mahdollisiksi tutkimusalueen kivennäismailla. Tutkimustiloilla esiintyy tosin myöskin mm. mustikkatyypin maata (vrt. taul. 4, p. 352), joiden tuotosluvut on edellä arvioitu alemmiksi. Kun metsien tarkat rakennetutkimukset yleensä on tehty koealoilta, joilla pu ustot ovat jotenkin säännöllisiä, saattavat tämäntapaisten laskelmien tulokset muutenkin johtaa keskimääräistä edullisempiin tuloksiin. Tämä on lopputuloksia arvosteltaessa syytä ottaa huomioon.

Pelkästään kasvullistenkin metsämaiden alasta on alueella yli $30 \%$ turvemailla. Tämän alan yhtä vähän kuin huonokasvuisten soiden metsäntuotantoa ei oteta mukaan alkuperäisessä muodossaan erillisenä tuotantoprosessina. Sitävastoin on oletettu, että uudisviljelijä lähinnä omalla työllään suorittaa näillä aloilla metsäojituksia, joiden tuotto voidaan arvioida joko sellaisena, kuin se kiertoajan puitteissa myöhemmin muodostuu tai diskontoituna vuosiin, joina uudisviljelijä eri metsäalojen ojitukset suorittaa.

Edellisellä menettelytavalla saadaan aikaan tuotantosuunnitelma, joka koskee jotain kaukaisen tulevaisuuden ajankohtaa. Jälkimmäisellä tavalla voidaan toimintojen vaikutus kytkeä tämän hetken tuotantosuunnitelmaan.

Edellistä tuotantoprosessia muodostettaessa on lähtökohtana kitukasvuista metsää kasvava suo, jonka ojittamisella saadaan pääasiallinen puuntuotto 70 90 vuoden kuluttua. Pidettäessä ojia kunnossa, mikä vaatii tietyn työmäärän (tässä edellytetty $0.75 \mathrm{t} / \mathrm{ha}$ ) vuodessa, saavutetaan 90 vuoden kiertoaikana vuotuinen ojitetun kangaskorven kasvua vastaava katetuotto, johon siis kantohintatulon lisäksi sisällytetään työtulo ja myös oman hevostyön korvaus. Tästä prosessista käytämme merkintää S 90 .

Ymmärrämme vaihtoehtoisen toisen tuotantoprosessin siten, että metsäojituksessa tehdylle omalle työlle saadaan katetuotto nykyhetkeen diskontoitavien kantohintatulojen muodossa. Tuotantoprosessia merkitään tässä kirjaimin SO.

Vastaavanlaisia tulevaisuudesssa saatavia katetuottoja nykyisin suoritetuista toiminnoista on mahdollista saavuttaa monella muullakin tavalla, esim. metsäpuiden istuttamisella ja kylvöllä, tukkipuustojen karsinnalla sekä maataloudessa esim. salaojituksessa, karjan kasvatuksessa ja jalostuksessa, mutta tämän tutkimuksen ohjelmiin ei otettu muita kuin edellä mainitut.

Kaikissa tuotantosuunnitelmissa esiintyy vaihtoehtoina ennen mainitut kaksi tekniikan tasoa. Yhden perheen tiloilla ei katsota mahdolliseksi hevosen ja traktorin pitoa yhtäaikaisesti. Toisaalta yhden hevosen tilan rajoitukset kiireaikoina ovat varsin tiukkoja, ellei vastavuoroista naapuriapua joustavasti sovelleta. Vastavuoroinen apu hevos- ja traktoritilojen välillä voisi ehkä vielä tuntuvammin kohottaa hevostilojen tehokkuutta. Talvisissa metsätöissä on suunnitelmissamme edellytettävä käytettäväksi hevosta, joita traktoritilojen oletetaan vuokraavan hinnalla, joka vastaa $60 \%$ työehtosopimusten mukaisista ajomiesten palkoista. Traktorimalli, joka on asetettu laskelmiemme pohjaksi, ei erityisen hyvin sovellu metsätöihin, etenkään alueen runsaslumisissa olosuhteissa. 


\section{Ensimmäiset, aggregoiduilla malleilla tehdyt tuotantosuunnitelmat}

Ensimmäinen LP-menetelmän soveltaminen itse tuotantosuunnitelmaan tapahtui pitkälle aggregoituja tuotantoprosesseja käyttäen. Kun tämä soveltaminen muodostui jossain määrin kokeiluluontoiseksi, johtaen osittain epämielekkäältä vaikuttaviin tuloksiin, selostamme sitä tässä vain lyhyesti. Kun sen eräät tulokset, joita on myöskin esitetty ennakkotiedon luontoisesti CIOSTA:n (Centre International pour l'Organisation Scientifique du Travail Agricole) Helsingin kokouksessa 1968, ovat tietyssä mielessä suuntaa antavia, esitämme seuraavassa niistä myös țärkeimpiä tuloksia (PIHKALA 1968).

Maatalouden tuotantoprosessien aggregoinnissa pidettiin eräänä perusyksikkönä nurmenviljelyn hehtaaria, laidunala siihen sisällytettynä. Sen sadon perusteella ja eläinten ruokintasuunnitelmien mukaisten nurmirehujen käyttömäärien perusteella laskettiin miten monta lypsylehmää, muuta nautaeläintä, hevosta tai lammasta tällä alalla voitiin pitää. Lihantuotantoon käytettävien nautaeläinten kohdalla voitiin vaihtoehtoinen tuotantoprosessi muodostaa saman periaatteen mukaan, mutta lisäksi muodostettiin tuotantoprosesseja sitomalla lihantuotanto maidontuotantoon. Tässä sitomisessa oli määräävä merkitys sillä, miten monta vasikkaa voitiin ruokkia paikallisen täysmaidon kulutuksen tyydyttämisen jälkeen voinvalmistuksen sivutuotteena saatavalla kuoritulla maidolla. Sikatalouden kohdalla asetettiin samalla tavalla kuorittu maito lehmää kohden pidettävän sikaluvun määrääjäksi. Lammastalous sitävastoin aggregoitiin pelkästään nurmenviljelyprosesseihin.

Metsätaloudellisia tuotantoprosesseja esiintyi ensimmäisissä suunnitelmissa 5, joista 2 ainoastaan sillä tavoin, että ne tulivat kysymykseen eri suunnitelmassa.

Jotta saataisiin yhtenäisempi kuva mukaan tulleista tuotantoprosesseista, esitetään alla tuotantoprosessien lyhennysmerkintä ja sisältö sekä katetuotot hehtaaria kohden tekn. I ja tekn. II :n olosuhteissa, myös kaksi maidon hintavaihtoehtoa (a) ja (b) huomioon ottaen (metsätalouden katetuotoissa vastaavasti merkityillä vaihtoehdoilla on tarkoitettu kantorahan ja työtulon tai pelkän työtulon muodostamaa katetuottoa).

Huomautettakoon tässä yhteydessä, että laskelmien perusteissa on tapahtunut, kuten katetuottolaskelmia selostettaessa on käynyt ilmi, eräitä oleellisesti vaikuttaviakin muutoksia uuden ja vanhan laskelman välillä.

Taulukko 14. Aggredoidun ohjelman katetuotot.

Table 14. Gross margins in the aggregated program.

Katetuotot - Gross margins

mk ha kohden - mk per ha

I (a) II (a) I (b) II (b)

M 28 A Pelkkä maidontuotanto, $2800 \mathrm{~kg} / \mathrm{v}$ edullinen

tuot. käyrä

$\begin{array}{lll}606 & 571 & 259\end{array}$

241

Milk production, favourable lactation curve

M 32 A Pelkkä maidontuotanto, $3200 \mathrm{~kg} / \mathrm{v}$ edullinen

tuot. käyrä

685

645

310

Milk production favourable lactation curve

Jatkuu - continues 
M 36 B Pelkkä maidontuotanto, $3600 \mathrm{~kg}$, epäedullinen tuot. kãyrä ......................................

Milk production, unfavourable lactation curve

M $36+$ B Maidontuotanto + ruohovasikan kasvatus .

Milk production + grass calves

3.9 vasikkaa/lehmää - calves/cow

M $36+\mathrm{C}$ Maidontuotanto + naudan kasv. 24 kk .......

Milk production + beef production, 24 months

3.9 vasikkaa/lehmäă - calves/cow

M $36+$ D Maidontuotanto + nauta 19 kk

Milk production + beef, 19 months

1.8 vasikkaa/lehmää - calves/cow

M 32 + D Maidontuotanto $3200 \mathrm{~kg}$ + nauta $19 \mathrm{kk} \ldots \ldots$. Milk production + beef, 19 months

1.6 vasikkaa/lehmää - calves/cow

M $28+$ D Maidontuotanto $2800 \mathrm{~kg}$ + nauta $19 \mathrm{kk} \ldots .$.

Milk production + beef, 19 months

M $36+\mathrm{S}$ Maidontuotanto + sianliha

$\begin{array}{llll}91 & 80 & 18 & 18\end{array}$

Milk + pork production

La Lampaankasvatus - Sheep growing

$\mathrm{He}$

6.76 lammasta/ha - sheep/ha $-284$

O

$$
1.1 \text { hevosta/ha - horse/ha }
$$

PeKo

$$
\text { Ohranviljely - Barley }
$$

Peruna, kotikäyttöön

\section{Potato for home use}

PeRe Peruna rehuksi - Potato for feed

$\begin{array}{llll}341 & 189 & 341 & 189\end{array}$

Mä $80 \mathrm{P}$ Mäntypuu, kiv.maill, $80 \mathrm{v}$, vain päätehakkuut

Pine, mineral soils, 80 years rotation, no thinning

Mä $100 \mathrm{P} \quad$ kuten edellä, $100 \mathrm{v},-$ d:o, 100 years $\ldots \ldots .$.

Mä $130 \mathrm{P} \quad$, $130 \mathrm{v}$., 130 , .......

Mä 100 PH Mäntypuu, kiv.maill, 100 v, pääte- ja harv. hakkuut

Pine, mineral soil, 100 yrs rot., thinning included

Mä $130 \mathrm{PH}$ Kuten edellä, 130 v. - d:o, 130 years.......... Mä S 90 Mäntypuu ojit. soilla, 90 v. kiertoaika .......... Pine, drained peat land, 90 years rotation

SO Suo-ojitukset, disk. kantohintatulo/ha ..........
Draining on peat land; discounted future income

Näistä tuotantoprosesseista, kuten edellisestä selviää, eivät voi yhtä aikaa olla mukana Mä S 90 ja SO. 


\section{LP-laskelman tuloksia}

Seuraavissa taulukoissa on edullisinta tuotantosuuntaa kuvattu luvuilla, joissa ensin viljelmän kivennäis- ja turvemaiden jakaantuminen maa- ja metsätalouden käyttöön sekä viljelijäperheen työvoimavarojen käyttö tai käyttämättä jääminen. Tämän jälkeen esitetään maa- ja metsätaloudesta yhteisesti saatava optimoitu katetuotto. Sitten mainitaan tärkeimpiä tuotantosuuntaa luonnehtivia lukuja, lypsylehmien, ruohovasikoiden, teurasnautojen, lihotussikojen ja lampaiden luku, ohran ja perunan viljelyala sekä väkirehutase ( - tarkoittaa väkirehun ja viljan ostoa viljelmän ulkopuolelta, + vastaavasti myyntejä). Laskelma voitaisiin tehdä yksityiskohtaisemmaksi selvittämällä eri tuotannonhaarojen osuus katetuotossa, väkilannoiteostojen suuruus ym., mikä edellyttäisi palaamista kunkin tuotannonhaaran katetuottolaskelmiin, mutta sitä ei ole katsottu tarpeelliseksi.

Esimerkiksi eläinluvut on tässä esitetty kokonaisiksi pyöristämättä. Ohjelmaa käytännössä toteutettaessa ei tietenkään voi ajatella, että pidettäisiin eläinten puolikkaita tai että etukäteen suunniteltaisiin lukumäärää tavantakaa muutettavaksi vuoden kuluessa, jotta päästäisiin suunnitelman mukaisiin keskiarvoihin. LP-tekniikka tuntee myös kokonaislukuihin päätyvän suunnittelun, mitä tässä ei kuitenkaan ole ryhdytty soveltamaan. Käytännössä ovat nyt sovelletun suunnitelman luvut vain ohjeena karjan suuruuden tarkoituksenmukaista määrittämistä varten.

Eräässä ensimmäisistä laskelmista määritettiin optimaalinen tuotantosuunta tutkimusajan hintasuhteissa edellyttäen, että maidontuotannon intensiteetti oli lehmien tuotantokapasiteetin mukaan nouseva ja että sikojen pito tuli mukaan yhdistettynä korkeimpaan maidontuotantotasoon (M $36 \mathrm{~A}+\mathrm{S})$. Tuotantosuunta määrättiin edellyttäen, että turvemaiden metsät oli saatettu lopulliseen tuottokuntoonsa. Näiden tulosten esittäminen on paikallaan senkin vuoksi, että jo alusta todetaan lypsykarjantuotannon voimaperäisyyden ja tekniikan tason vaikutus (Taulukko 15).

Taulukon lukuja tarkasteltaessa huomataan, että katetuotto nousee, joskaan ei kovin voimakkaasti, korkeampaan maidon keskituotantoon siirryttäessä. Maito-sikatalous-yhdistelmä antaa korkeimman katetuoton. Naudan- ja lampaanlihantuotanto jää tekniikassa I pois, mutta tekniikassa II, jossa nurmenviljely turvemailla on $3-4$ kertaa laajempaa, lampaat tulevat voimakkaasti kuvaan. Ohranviljely laajenee huomattavaa myyntiä edellyttäväksi. Lehmiä on tekn. I:ssä 5-6 kpl, mutta tekn. II:ssa vain pari kappaletta. Turvemaan metsien osuus on huomattava, vaikka kaikki turvemaa ei silti tule käytetyksi. Myös ihmistyön kapasiteetista on n. neljännes, jopa enempi käyttämättä.

Näissä tuloksissa on etenkin tekniikka II:n osalta paljon epärealistista. Panos-tuotoskertoimet ovat etenkin lampaiden ja ohran kohdalta tässä tekniikassa varmaankin olleet liian edullisia. Edellä on huomautettu suuresta erosta työnmenekkiluvuissa lampaiden osalta tämän ja myöhempien laskelmien välillä. On myöskin esitetty epäilyä lammastalouden laajentamisesța turvemailla. Ihmistyön suhteellisesti heikko hyväksikäyttö johtuu suurelta osalta siitä, että metsätyö oli LP-taulukossa rajoitettu pelkästään ns. muuhun aikaan. Tästä 
Taulukko 15. Uudistilan maa-alan ja perheen työvoiman käyttō, katetuotto ja eräitä tuotantosuuntaa osoittavia lukuja optimoidun tuotantosuunnitelman mukaan. Kolme maidontuotannon tasoa, maitotalous yhd. sikatalouteen. M. hinta $-: 36$.

Table 15. The use of land and family labour, gross margin to labour, and some indicators of production. Three levels of milk production capacity, milk production also combined with pigs. Milk price $-: 36$.

\begin{tabular}{|c|c|c|c|c|c|c|c|c|}
\hline & \multicolumn{4}{|c|}{ Tekniikka I - Techn. I } & \multicolumn{4}{|c|}{ Tekniikka II - Techn. II } \\
\hline & $28 \mathrm{~A}$ & $32 \mathrm{~B}$ & $36 \mathrm{~A}$ & $36 \mathrm{~A}+\mathrm{S}$ & $28 \mathrm{M}$ & $32 \mathrm{~B}$ & $36 \mathrm{~A}$ & $36 \mathrm{~A}+\mathrm{S}$ \\
\hline \multirow{2}{*}{\multicolumn{9}{|c|}{$\begin{array}{l}\text { Maata maataloudellisessa käyt. } \\
\text { Land in agricultural use, ha }\end{array}$}} \\
\hline & & & & & & & & \\
\hline kivennäism. - mineral ... & 1.62 & 1.73 & 1.82 & 1.99 & 19.35 & 19.34 & 19.36 & 18.44 \\
\hline $\begin{array}{l}\text { turvem. - peat .............. } \\
\text { Maata metsätal. käyt. }\end{array}$ & 6.95 & 6.62 & 6.34 & 5.77 & 21.68 & 21.79 & 21.66 & 20.20 \\
\hline \multicolumn{9}{|l|}{ Land in forestry use } \\
\hline kivennäism. - mineral ... & 78.38 & 78.28 & 78.19 & 78.01 & 60.65 & 60.66 & 60.64 & 61.56 \\
\hline turvem. - peat ............. & - & - & - & - & 49.92 & 49.90 & 49.92 & 48.81 \\
\hline Perheen tyővoimaa käyt. t. & 2595 & 2627 & 2615 & 2622 & 2574 & 2579 & 2574 & 2761 \\
\hline \multicolumn{9}{|l|}{ Family labour in use, hrs } \\
\hline ei käytössä - unused ..... & 952 & 920 & 932 & 925 & 963 & 968 & 973 & 786 \\
\hline Katetuotto ....................... & 9656 & 9924 & 10076 & 10514 & 11838 & 12719 & 12800 & 12856 \\
\hline \multicolumn{9}{|l|}{ Gross margin $m k$} \\
\hline Lehmiä - Cows ................ & 6.4 & 5.9 & 5.3 & 4.8 & 2.5 & 2.3 & 2.0 & 1.9 \\
\hline Ruohovasik. - Grass calves & - & - & - & - & - & - & - & - \\
\hline Sikoja - Pigs .................. & - & - & - & 34.5 & - & - & - & 14.6 \\
\hline Lampaita - Sheeps .......... & - & - & - & - & 130.6 & 135.3 & 132.2 & 127.4 \\
\hline Ohraa, - Barley ha ............ & 1.38 & 1.48 & 1.58 & 1.75 & 19.11 & 19.06 & 19.12 & 18.20 \\
\hline Rehuv. tase - Feed grain ... & -219 & -2121 & -390 & -10956 & +18930 & +18930 & +18817 & +13185 \\
\hline Öljykakk. ostet. - Oil cakes & 115 & 133 & 382 & 346 & 180 & 45 & 144 & 137 \\
\hline
\end{tabular}

syystä kasvukauden työtunteja, joita olisi siihen ilmeisesti voitu käyttää, on jäänyt käyttämättömiksi.

Samalla kertaa tehdyssä rinnakkaislaskelmassa jätettiin lampaat pois tuotantosuunnitelmasta. Laskelman tulokset on esitetty Taulukossa 16.

Kuten huomataan, lampaan poistaminen on kohottanut lehmälukua tekn. II:ssa, mutta ei ole tuonut esim. ruohovasikan kasvatusta kuvaan. Lehmien lisäys ei ole antanut mahdollisuutta turvemaiden metsien hoitoon. Mutta tämäkin laskelma on epäonnistunut osaksi siksi, että muun kasvukauden aikaa ei ollut annettu metsätalouden käyttöön.

Mikäli laskelmissa käytettiin alempaa maidonhintaa, voitiin havaita, että turvemetsien laajentaminen tuli kuvaan, ja myöskin ruohovasikan kasvatus osoittautui kilpailukykyiseksi. Vanhemman teurasnaudan kasvatus ei yhdessäkään tapauksessa tullut kysymykseen.

Eräät kokeilut osoittivat, että jos ohranviljelylle asetettiin yläraja ja kivennäismaan metsältä poistettiin kokonaan yläraja, metsäala voimakkaasti laajeni suunnitelmassa. Se ei kuitenkaan ole tämän tutkimuksen alussa asetettuihin rajoituksiin soveltuvaa. 
Taulukko 16. Uudistilan maa-alan ja perheen työvoiman käyttö, katetuotto ja eräitä tuotantosuuntaa osoittavia lukuja optimoidun tuotantosuunnitelman mukaan. Samat vaihtoehdot kuin Taulukossa 15, mutta lampaat jätetty pois tuotantosuunnitelmasta.

Table 16. The use of land and family labour, gross margin to labour, and some indicators of production. The same alternatives as in Table 15, but without sheep.

Voimaperäisyys - Intensity level $\frac{c}{28 \mathrm{M} \quad 32 \mathrm{M} 36 \mathrm{M} 36 \mathrm{M}+\mathrm{S}} \frac{}{28 \mathrm{M} 32 \mathrm{M} 36 \mathrm{M} 36 \mathrm{M}+\mathrm{S}}$

Maata maatalouden käytössä

\begin{tabular}{|c|c|c|c|c|c|c|c|c|}
\hline kivennäism. - mineral .......... & 1.62 & 1.73 & 1.82 & 1.99 & 16.11 & 15.88 & 16.08 & 16.61 \\
\hline turvem. - peat ................... & 6.95 & 6.62 & 6.34 & 5.78 & 7.00 & 6.62 & 6.30 & 5.76 \\
\hline \multicolumn{9}{|l|}{ Maata metsätal. käytössä } \\
\hline \multicolumn{9}{|l|}{ Land in forestry use } \\
\hline kivennäism. - mineral ....... & 78.38 & 78.28 & 78.18 & 78.01 & 63.89 & 64.11 & 63.92 & 63.39 \\
\hline turvem. - peat ................ & - & - & - & - & - & - & - & - \\
\hline \multicolumn{9}{|l|}{ Perheen tyōvoimaa, $\mathrm{t}$} \\
\hline \multicolumn{9}{|l|}{ Family labour, hrs } \\
\hline käytössä - in use ............. & 2595 & 2567 & 2550 & 2822 & 2744 & 2733 & 2826 & 3141 \\
\hline ei käytössä - unused ........... & 1276 & 1304 & 1322 & 1050 & 1128 & 1139 & 1045 & 730 \\
\hline Katetuotto - Gross margin, $\mathrm{mk}$ & 9656 & 9771 & 10076 & 10514 & 10099 & 10368 & 10543 & 10970 \\
\hline Lehmiä - Cows ..................... & 6.4 & 5.9 & 5.3 & 4.8 & 7.5 & 6.5 & 6.3 & 5.8 \\
\hline Ruohovas. - Grass calves ......... & - & - & - & - & - & - & - & - \\
\hline Sikoja - Pigs ...................... & - & - & - & 34.5 & - & - & - & 41.4 \\
\hline Lampaita - Sheep ................. & - & - & - & - & - & - & - & - \\
\hline Ohraa - Barley ................... & 1.38 & 1.49 & 1.58 & 1.75 & 15.87 & 15.65 & 15.84 & 16.60 \\
\hline Rehuviljatase - Feed grain ....... & -215 & -334 & $-276-$ & $10926+$ & 20837 & +20393 & +20115 & +7498 \\
\hline Öljykakut - Oil cakes ............ & 115 & 136 & 382 & 348 & 135 & 150 & 454 & 415 \\
\hline
\end{tabular}

Toisaalta osoittautui, että kasvatushakkuiden ja suo-ojitusten ottaminen suunnitelmaan vähensi hukkaan menevää työaikaa. Esimerkki tästä voidaan esittää seuraavassa asetelmassa, jonka perustana on $3600 \mathrm{~kg}: \mathrm{n}$ maidontuotanto.

Maidon hinta - Milk price ..........................

Maata maatalousk. - Agric. use .....................

- metsätal. - Forestry use .....................

Perheen työtä - Family labour ...................... käyttämättä - unused

Katetuotto - Gross margin

siitä diskont, tuloa - discounted income

Lehmiä - Cows $36 \mathrm{~A}+\mathrm{S}$

Ruohovasik. - Grass calves

Sikoja - Pigs .

Lampaita - Sheep

Ohraa - Barley

Kasvatushakkuita - Thinning work

Suo-ojituksia - Peat draining
Tekn. I - Techn.

\begin{tabular}{rrrr}
\multicolumn{1}{c}{ (a) } & (b) & \multicolumn{1}{c}{ (a) } & (b) \\
8.87 & 13.98 & 27.92 & 28.95 \\
74.49 & 71.45 & 70.43 & 64.67 \\
3566 & 3742 & 3650 & 3708 \\
197 & 21 & 113 & 55 \\
11639 & 10620 & 13413 & 11516 \\
184 & 1169 & 184 & 1172 \\
5.5 & 5.4 & 5.2 & 4.9 \\
- & - & - & - \\
- & - & - & - \\
- & 7.34 & 13.14 & 13.72 \\
3.1 & 0.93 & 9.33 & 9.79 \\
- & 5.00 & - & 5.00 \\
2.14 & 2.25 & 2.13 & 2.29
\end{tabular}


Näissä vaihtoehdoissa on aika tullut tarkkaan käytetyksi. Maidonhinnalla 36 p (a) saadut katetuotot nousevat suuremmiksi kuin vastaavissa edelläesitetyissä tapauksissa. Lammas näyttelee laskelmissa melko suurta osaa. Diskontatun tulevan tulon suhteellinen osuus ei ole kuitenkaan ollut erityisen suuri.

\section{Disaggregoidut LP-laskelmat}

Aggregoitujen laskelmien tuloksiin tutustuttaessa sai piankin sen vaikutelman, että niihin sisältyi muutakin epärealistista kuin ilman riittävän huolellista harkintaa asetetuista rajoituksista ja mahdollisesti epäonnistuneesti arvioiduista muuttuvista kustannuksista johtuvaa. Aggregoinnilla on, kuten metodista puhuttaessa tuli esille, tuotantosuunnitelmaa jäykistävä vaikutus. Mutta lisäksi tuotannon laajuuden ekonomian täydellinen sivuuttaminen ei ole voinut olla vaikuttamatta tällaisen vaikutelman syntymiseen.

Tämän vuoksi päätettiin kokeilla disaggregoidulla mallilla, ja lisäksi ainakin tärkeimmän tuotannonhaaran, maidontuotannon kohdalla yrittää selvittää suuremmissa karjoissa havaittavan ihmistyön tehostumisen vaikutus tuotantosuunnitelmaan. Tietenkin on omat vaaransa sillä, että korjausmenetelmää sovelletaan vain yhden tuotannonhaaran osalta. Sehän saattaa johtaa suunnitelmaa asianomaista tuotannonhaaraa suosivaan suuntaan toisten kustannuksella. LP-tekniikkaa saattaa ehkä kehittyä ja on ehkä jo kehittynytkin pitemmälle tässä suhteessa. Voinemme kuitenkin tehdä verraten yksinkertaisia laskelmia, kun pidämme mielessä, että saadut luvut ovat lähinnä suuntaa antavia.

Seuraavassa esitettävät tuotantosuunnitelmat poikkeavat ensimmäisistä aluksi siinä, että pellonviljelyn tuotantoprosessit on yhdistetty kotieläintalouden tuotantoprosesseihin itse LP-ohjelmassa. Ohranviljely, joka oli edellä katsottu itsenäiseksi tuotantoprosessiksi, esiintyy uudessa suunnitelmassa kuten nurmenviljelykin, rehua tuottavana prosessina. Ohran myyminen ei siis tule kysymykseen, mutta kyllä ostaminen hinnoin, jotka oli asetettu korkeammaksi maan keskihintoja. Perunanviljely yli kotitarpeen katsottiin niinikään vain omaa rehuntarvetta tyydyttäväksi tuotantoprosessiksi. Metsätyötä ei enää rajoitettu tiettyyn vuodenaikaan, vaan rajoitus siirtyi kokonaistyöaikaan.

Taulukossa 17 on esitetty tulokset näistä eri maidontuotantovaihtoehdoista, hintatilanteen (a) mukaan. Lukuja tarkasteltaessa kiintyy huomio siihen, että edullisin katetuotto edellyttää tuotantosuuntaa, joka miltei yksinomaan perustuu maidontuotantoon. Vain tekniikka II:n osalta sika- ja lammastalous saattaa tulla kuvaan. 
Taulukko 17. Disaggregoidun ohjelman mukaan lasketut tulokset, karjatalouden tyōnmenekkiluvut riippumattomat lehmäluvusta. Maidon hinta $36 \mathrm{p}$.

Table 17. Results of the disaggregated program, labour hours per cow independent of the size of herd. Milk price 36 p.

\begin{tabular}{|c|c|c|c|c|c|c|}
\hline & \multicolumn{3}{|c|}{ Tekniikka I - Technique } & \multicolumn{3}{|c|}{ Tekniikka II - Technique } \\
\hline & M28A & M32A & M36B & M28A & M32A & M36B \\
\hline $\begin{array}{l}\text { Maata maatal. käyt., yht. ha } \\
\text { Land in agr. use - Total }\end{array}$ & 9.21 & 9.23 & 9.19 & 13.37 & 15.04 & 15.88 \\
\hline kivennäism. - mineral soil & 1.03 & 1.02 & 1.03 & 2.81 & 3.44 & 4.49 \\
\hline turvem. - peat soil .......... & 8.18 & 8.21 & 8.16 & 10.56 & 11.60 & 11.39 \\
\hline $\begin{array}{l}\text { Maata metsätal. käyt., ha .... } \\
\text { Land in forestry use }\end{array}$ & 78.97 & 78.98 & 78.97 & 77.2 & 76.6 & 75.5 \\
\hline Pääoma - Capital ............. & 199440 & 199440 & 199440 & 221562 & 141818 & 141052 \\
\hline Perheen työtä t .................. & 3972 & 3972 & 3972 & 3972 & 3972 & 3972 \\
\hline $\begin{array}{l}\text { Family labour, } h \\
\text { Aputyövoimaa, t. ................. } \\
\text { Hired labour, } h\end{array}$ & 27 & 3 & 17 & - & 16 & 31 \\
\hline $\begin{array}{l}\text { Katetuotto - Gross margin } \\
\text { Nurmenvilj.tuot.pros. - Grass }\end{array}$ & 10171 & 10769 & 11270 & 11932 & 12924 & 13758 \\
\hline $\mathrm{TiA}_{1} \ldots \ldots \ldots \ldots \ldots \ldots$ & 2.37 & 2.32 & 2.59 & 3.67 & 3.27 & 3.85 \\
\hline $\mathrm{TiA}_{3} \mathrm{~B}_{2} \ldots \ldots \ldots \ldots \ldots \ldots \ldots \ldots \ldots \ldots \ldots$ & 0.94 & 0.52 & 0.54 & - & - & - \\
\hline $\mathrm{TiC}_{2} \ldots \ldots \ldots \ldots \ldots \ldots \ldots$ & - & - & - & 0.26 & 11.1 & 0.60 \\
\hline 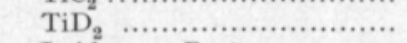 & 1.75 & 2.24 & 1.85 & 2.57 & 2.95 & 2.61 \\
\hline Laidun - Pasture ........... & 3.12 & 3.12 & 3.19 & 4.07 & 4.27 & 4.33 \\
\hline Ohra - Barley ............. & 0.79 & 0.78 & 0.79 & 2.57 & 3.20 & 3.48 \\
\hline Peruna - Potato ............ & 0.24 & 0.24 & 0.24 & 0.24 & 0.24 & 0.24 \\
\hline Hevonen - Horse .......... & 1.0 & 1.0 & 1.0 & - & - & - \\
\hline Lehmät - Cows ............. & 8.5 & 8.1 & 7.8 & 10.6 & 12.3 & 11.8 \\
\hline Ruohovasikat - Grass calves & - & - & - & - & - & - \\
\hline Teurasnaudat - Beef cattle ... & - & - & - & - & - & - \\
\hline Siat - Pigs .................... & - & - & - & 4.5 & 4.5 & 4.5 \\
\hline Lampaat - Sheep .............. & - & - & - & 5.3 & - & - \\
\hline Måntypuu - Pine $80 \mathrm{P} \ldots$. & - & - & - & 5.3 & - & - \\
\hline,$\quad 100 \mathrm{P} \ldots$ & - & - & - & - & - & 76.6 \\
\hline , 130 P.... & - & - & - & - & - & - \\
\hline , $100 \mathrm{PH}$. & 8.36 & 7.93 & 7.71 & 77.2 & - & - \\
\hline$\Rightarrow 130 \mathrm{PH}$ & 70.61 & 71.05 & 71.26 & - & - & - \\
\hline $\begin{array}{l}\text { Suo-ojitukset ............................... } \\
\text { Peat draining }\end{array}$ & - & - & - & - & - & - \\
\hline $\begin{array}{l}\text { Rehuviljaostot, } \mathrm{kg} \text {.............. } \\
\text { Purchases of grain, fu. }\end{array}$ & 1487 & 1975 & 2281 & - & - & - \\
\hline
\end{tabular}


Katetuotto on traktoritekniikassa ollut korkeampi kuin hevostekniikassa. Traktoritekniikka on tehnyt mahdolliseksi laajemman alan viljelyn ja karjan luvun lisäämisen. Hevostekniikassa on rajoittavana tekijänä ollut lähinnä viljelijäperheen työvoima heinäaikana ja hevosen työaika kylvöaikana. Traktorin vuokrausmahdollisuus varsinkin kylvökautena parantaisi hevostekniikkatilojen mahdollisuuksia. Traktoritekniikan vaikutus katetuottoon ei ehkä kuitenkaan ole ollut niin suuri kuin maataloustuotannon lisääntymisen nojalla olisi saattanut odottaa. Rahalliset kustannukset ovat vaikuttaneet supistavasti, mutta sentään nousee katetuotto suunnilleen 2000 markan verran.

Lehmien tuotantokapasiteetin nousu on lisännyt katetuottoa, joten myös noin tuhannen markan lisäys katetuottoon on saatu kohotettaessa karjan keskilypsyä 400 kilolla vuodessa. Näistä vaihtoehdoista korkein, $3600 \mathrm{~kg}$, liittyy myöskin korkeimpaan viljelmän katetuottoon.

Korkein katetuotto, n. $13800 \mathrm{mk}$, on saavutettu traktoritekniikan olosuh teissa tilalla, jolla peltoalaa on n. 16 ha, lehmiä 12 , sikoja 4,5, ja jonka koko mineraalimaalla oleva metsäala hoidetaan 100 vuoden kierrossa ilman harvennushakkuita. Harvennushakkuut tulevat mukaan tekniikka I:n olosuhteissa.

\section{Muuttuvia lypsykarjan työnmenekkilukuja soveltaen tehdyt laskelmat}

Viimeiset LP-laskelmat tehtiin soveltaen karjan suuruuden mukaan muuttuvia lypsykarjan työnmenekkilukuja. Näissä laskelmissa käytettiin vain yhtä maidontuotannon tasoa, $3200 \mathrm{~kg}$, mutta sovellettiin kolmea eri hintaa maidolle, 36 p (a), 25 p (b) ja 70 p (c). Viimeksimainitussa tapauksessa on, kuten aikaisemmin p. 380 on mainittu, myös eräitä muita hintoja muutettu, pyrkien sillä tavoin enemmän painatusvuoden hintasuhteita vastaaviin tuloksiin. Edelleen suoritettiin kaksi ajoa, joilla pyrittiin selvittämään, miten vaikuttaisi tuloksiin puuston arvon koron huomioonottaminen muuttuvina kustannuksina.

Tässä yhteydessä haluttiin myöskin selvittää, missä määrin nurmiviljelyn hehtaarisatojen poikkeamat tässä tutkimuksessa yleisesti sovelletusta tasosta vaikuttaisivat katetuottoihin. Tällöin otettiin vaihtoehtoina laskuperustaksi $10 \%$ yli tai $10 \%$ alle keskiarvon menevät rehuyksikkösadot. Vaihtelurajat vastaavat suunnilleen yli ja alle keskitason satoja saaneiden tutkimustilojen keskiarvoja ja kuvastavat toisaalta myös hyvien ja huonojen rehuvuosien satoeroja.

Vielä suoritettiin yksi tietokoneajo myöskin siinä mielessä, että nähtäisiin, vaikuttaisivatko maatalouden nykyisen työaikalain rajoitukset viljelijän ja hänen vaimonsa työajan käytössä suuremmassa määrin katetuottoon.

Taulukosta 18 nähdään, etțä silloin kun vertailumahdollisuus kiintein työnmenekkiluvuin laskettuun katetuottoon on olemassa $(3200 \mathrm{~kg}$, maidonhinta 36 p.) uudet laskelmat tekn. I:n kohdalta eivät paljonkaan muuta kațetuottoa. Lehmien luku nousee n. kahdella. Kylvö- ja heinäajan tiukat rajoitukset ihmisja hevostyön käyttömahdollisuuksista eivät näytä sallivan maataloustuotannon suurta lisäämistä. Muuna kasvukautena esiintyvät mahdollisuudet tuovat kuvaan metsäojitukset, joista ja lehmäluvun lisäyksestä johtuen viljelijäperheen työvoima on tullut verraten tarkoin käytetyksi. 
Taulukko 18. Disaggregoidun ohjelman mukaan lasketut tulokset, maitotuotos $3200 \mathrm{~kg} / \mathrm{v}$, karjatalouden työnmenekkiluvut porrastetut.

Table 18. Results of the disaggregated program, milk yield $3200 \mathrm{~kg}$ per year, labour hours per cow according to the size of herd.

\begin{tabular}{|c|c|c|c|c|c|c|}
\hline \multicolumn{2}{|c|}{$\begin{array}{l}\text { Maidon hintatilanne - Milk price } \\
\text { Tekniikka - Technique }\end{array}$} & (a) & $\mathrm{I}^{(\mathrm{b}}$ & II & \multicolumn{2}{|c|}{ (c) } \\
\hline $\begin{array}{l}\text { Maata maatal.käyt. yht. } \mathrm{kg} . \\
\text { Land in agr. use, total ha }\end{array}$ & 10.61 & 20.51 & 9.90 & 28.26 & 10.95 & 21.38 \\
\hline kivennäism. - mineral soil & 0.39 & 4.43 & 0.72 & 4.97 & 0.24 & 4.37 \\
\hline turvem. - peat soil ........... & 10.22 & 16.08 & 9.18 & 23.29 & 10.71 & 17.01 \\
\hline $\begin{array}{l}\text { Maata metsätal. käytössä, ha } \\
\text { Land in forestry use }\end{array}$ & 79.61 & 77.57 & 79.28 & 75.03 & 79.76 & 76.01 \\
\hline Pääoma - Capital ............. & 199440 & 162405 & 130245 & 255245 & 190141 & 247777 \\
\hline $\begin{array}{l}\text { Perheen tyőtä .............................. } \\
\text { Family labour }\end{array}$ & 3972 & 3972 & 3972 & 3972 & 3972 & 3972 \\
\hline $\begin{array}{l}\text { Aputyövoima, t } \ldots \ldots \ldots \ldots \ldots \ldots . . . . . . . \\
\text { Hired labour } h\end{array}$ & 33 & 73 & 18 & 128 & 55 & 91 \\
\hline $\begin{array}{l}\text { Katetuotto - Gross margin } \\
\text { Nurmivilj.tuot.pros. } \\
\text { Grassland }\end{array}$ & 11734 & 16107 & 8926 & 11179 & 25035 & 31840 \\
\hline 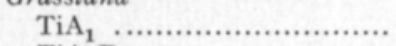 & 2.86 & 4.53 & 2.62 & 7.54 & 3.04 & 4.79 \\
\hline $\mathrm{TiA}_{3} \mathrm{~B}_{2}$ & 0.66 & - & 0.52 & - & 0.62 & - \\
\hline 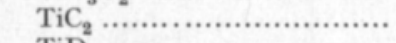 & $\overline{-}$ & 1.54 & $\overline{-}$ & 0.53 & - & 1.63 \\
\hline 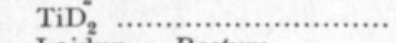 & 2.81 & 4.09 & 2.26 & 3.29 & 2.64 & 4.33 \\
\hline Laidun - Pasture............ & 3.90 & 5.92 & 3.78 & 11.92 & 4.41 & 6.26 \\
\hline Ohra - Barley .................. & 0.15 & 4.19 & 0.48 & 4.65 & - & 3.75 \\
\hline Peruna - Potato ............. & 0.24 & 0.24 & 0.24 & 0.32 & 0.24 & 0.24 \\
\hline Hevonen - Horse .............. & 1.0 & - & 1.0 & - & 1.0 & - \\
\hline Lehmät - Cows ................. & 10.4 & 17.1 & 8.2 & 5.9 & 9.7 & 18.1 \\
\hline Ruohovasikat - Grass calves & - & - & 6.1 & 4.4 & 7.3 & - \\
\hline Teurasnaudat - Beef cattle ... & - & - & - & - & - & - \\
\hline Siat - Pigs ....................... & - & 4.5 & 4.5 & 7.4 & 4.5 & - \\
\hline Lampaat - Sheep ............ & - & - & - & 87.2 & - & - \\
\hline Mäntypuu - Pine $80 \mathrm{P} \ldots .$. & - & $=$ & - & - & $=$ & - \\
\hline,$\quad 100 \mathrm{P} \ldots$ & - & 75.57 & - & - & 32.50 & $-\overline{0}$ \\
\hline - $130 \mathrm{P} \ldots .$. & - & - & - & - & - & 76.01 \\
\hline , 100 РН... & 16.89 & - & 79.28 & $-\overline{0}$ & - & - \\
\hline , 130 РН... & 62.72 & - & - & 75.03 & 47.26 & - \\
\hline Suo-ojitukset - Peat drain ... & $\overline{-}$ & - & - & - & - & - \\
\hline $\begin{array}{l}\text { Rehuviljaostot, ry }, \ldots \ldots \ldots \ldots . . . \\
\text { Purchases of grain, fu }\end{array}$ & 3866 & - & 4329 & - & 5833 & - \\
\hline
\end{tabular}

Tekniikka II:n kohdalla uudet laskelmat lisäävät sekä viljelyalaa että kotieläinkantaa varsin tuntuvasti; nurmenviljelyä n. 6 ha:lla ja lehmälukua 10:1lä. Katetuotto nousee n. $\mathbf{5} 000 \mathrm{mk}$ :lla. Metsäojitukset jäävät tässä vaihtoehdossa pois, ja työaika ei riitä myöskään harvennushakkauksiin.

Maidon ja muiden kotieläintuotteiden hintasuhteen muuttaminen maidolle epäedulliseksi vähentää lehmälukua noin kahdella ja tuo mukaan ruohovasikan ja lihotussian kasvatuksen, tekniikassa I lähinnä ostoviljaan, tekniikassa II omaan ohranviljelyyn perustuvana. Suometsien ojitus ei tule mukaan kummassakaan tekniikassa. Katetuotto alenee maidonhinnan jäädessä 25 p:iin jopa 5000 mk:lla tekniikassa II. Vuoden 1972 hintatasossa katetuotot ovat yli kahdenkertaisia 1959-63 hintatasoon verrattuna. Tekniikassa I sekä siat että ruohovasikat kuuluvat tuotantosuunnitelmaan, tekniikassa II tulevat mukaan myös lampaat. 
Nurmenviljelyn hehtaarisatoerojen vaikutus, jota ei tässä esitetä taulukon muodossa, tuntuu katetuotoissa n. 500-1000 markan lisäyksinä tai vähennyksinä tilaa kohden. Lehmälukua voidaan lisätä noin yhdellä nurmen satojen ylittäessä keskitason $10 \%$, vähentäminen on välttämätön päinvastaisessa tapauksessa. Suometsien ojitukseen jää vähän enemmän aikaa sadon ja karjamäärän vähentyessä.

Taulukko 19. Disaggregoidun ohjelman mukaan lasketut tulokset, maitotuotos $3200 \mathrm{~kg} / \mathrm{v}$. karjatalouden työnmenekkiluvut porrastetut, puuston hakkuuarvon korko $(3 \%)$ vähennettynä metsätalouden katetuotosta.

Table 19. Results of the disaggregated program, milk yield $3200 \mathrm{~kg}$ per year, labour hours per cow according to the size of herd, 3 per cent interest on the value of standing timber subtracted.

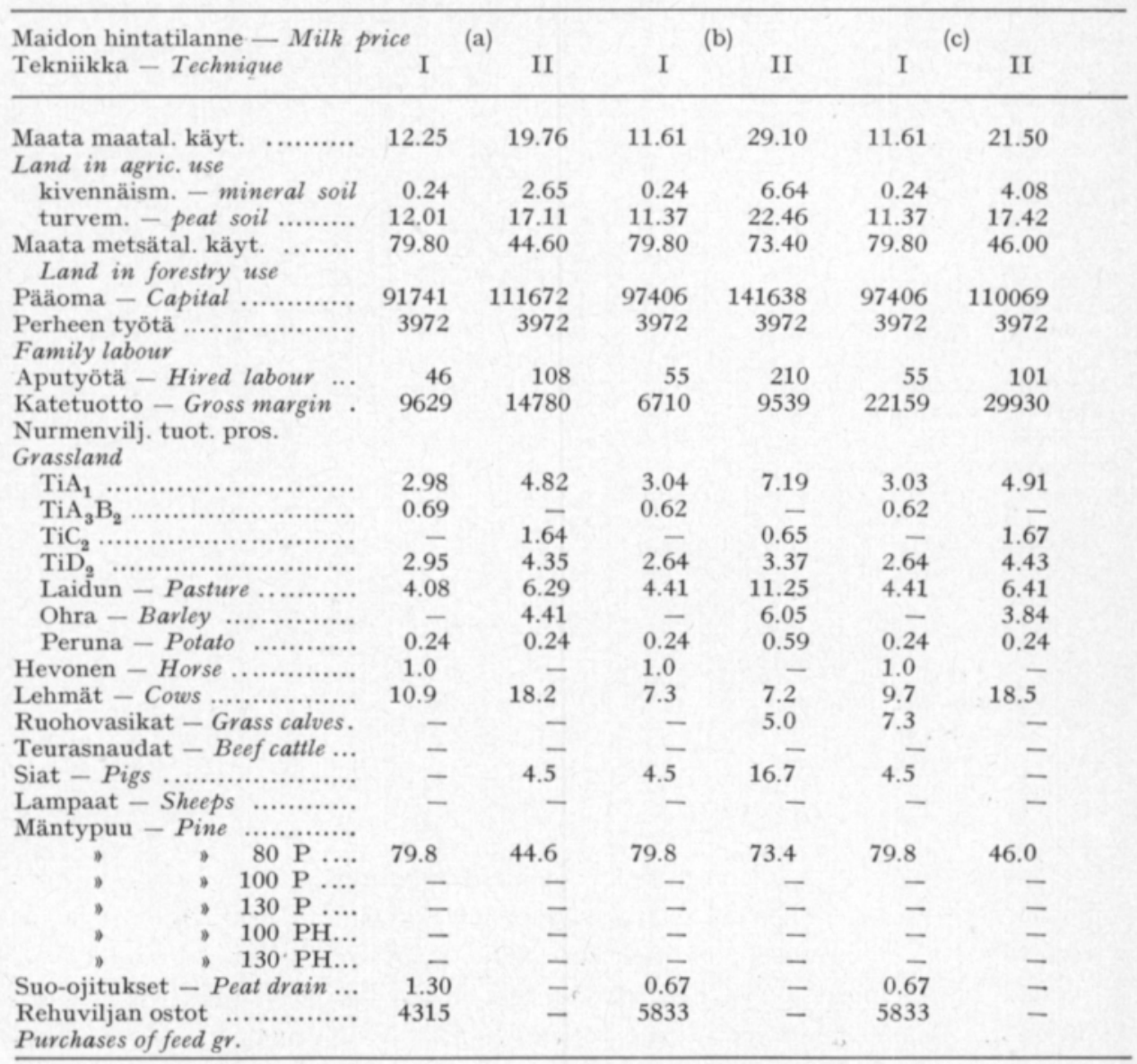

Jos puuston hakkuuarvon korko lasketaan mukaan muuttuviin kustannuksiin, mitä voitaneen loogisesti perustella, ottaen huomioon että hakkuukypsää puustoa voidaan pitää varsin likviidinä omaisuutena, muuttuvat laskelmien tulokset $3 \%$ :n korkokantaa käytettäessä melkoisesti. Taulukosta 19 nähdään, että mäntypuun kasvatukseen ainoastaan 80 vuoden kiertoaika tulee kuvaan. Suo-ojitukset näyttävät pystyvän kilpailemaan harvennushakkuiden kanssa. Esiintyypä tapauksia, joissa vain osa metsäalasta tulee tuotantosuunnitelmaan. 
Taulukko 20. Disaggregoidun ohjelman mukaan lasketut tulokset, maitotuotos $3200 \mathrm{~kg} / \mathrm{v}$. karjatalouden työnmenekkiluvut porrastetut, puuston hakkuuarvon korko (3\%) vähennettynä, viikottainen työaika $40 \mathrm{t}$.

Table 20. Results of the disaggregated program, milk yield $3200 \mathrm{~kg}$ per year, labour hours according to the size of herd, 3 per cent interest on the value of standing timber subtracted, labour hours $40 \mathrm{~h} /$ week

\begin{tabular}{|c|c|c|c|c|c|c|}
\hline $\begin{array}{l}\text { Maidon hintatilanne - Milk } \\
\text { Tekniikka }- \text { Technique }\end{array}$ & price & a) & \multicolumn{2}{|c|}{ (b) } & I & II \\
\hline $\begin{array}{l}\text { Maata maatal. käyt., ha ....... } \\
\text { Land in agr. use ha }\end{array}$ & 9.77 & 20.91 & 9.42 & 27.56 & 10.95 & 20.45 \\
\hline kivennäism. - mineral soil & 0.77 & 4.50 & 0.94 & 4.61 & 0.24 & 3.89 \\
\hline turvem. - peat soil .......... & 9.00 & 16.41 & 8.48 & 22.95 & 10.71 & 16.56 \\
\hline $\begin{array}{l}\text { Maata metsätal. käytössä, ha } \\
\text { Land in forestry use }\end{array}$ & 79.20 & 0.84 & 79.10 & 75.40 & 35.90 & 5.10 \\
\hline Pääoma - Capital ............. & 84207 & 83617 & 86985 & 128168 & 72630 & 82811 \\
\hline Perheen työtä .................... & 3343 & 3343 & 3343 & 3343 & 3343 & 3343 \\
\hline Family labour & & & & & & \\
\hline $\begin{array}{l}\text { Aputyövoimaa t .................. } \\
\text { Hired labour, } h\end{array}$ & 7 & 91 & 4 & 96 & 55 & 79 \\
\hline $\begin{array}{l}\text { Katetuotto - Gross margin... } \\
\text { Nurmivilj.tuot.pros. }\end{array}$ & 8768 & 12813 & 6239 & 8583 & 19365 & 26434 \\
\hline Grassland & & & & & & \\
\hline $\mathrm{TiA}_{1} \ldots \ldots \ldots \ldots \ldots \ldots \ldots \ldots \ldots \ldots \ldots \ldots \ldots$ & 2.53 & 4.62 & 2.44 & 7.51 & 3.04 & 4.67 \\
\hline $\mathrm{TiA}_{3} \mathrm{~B}_{2} \quad \ldots \ldots \ldots \ldots \ldots \ldots \ldots \ldots \ldots \ldots \ldots$ & 0.57 & - & 0.48 & - & 0.62 & - \\
\hline 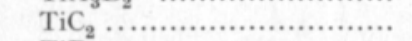 & - & 1.58 & - & 0.41 & - & 1.59 \\
\hline 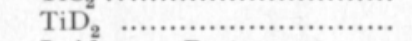 & 2.47 & 4.18 & 2.08 & 3.15 & 2.64 & 4.21 \\
\hline Laidun - Pasture ........... & 3.43 & 6.04 & 3.49 & 11.87 & 4.41 & 6.09 \\
\hline Ohra - Barley ............... & 0.53 & 4.26 & 0.70 & 4.28 & - & 3.65 \\
\hline Peruna - Potato ........... & 0.24 & 0.24 & 0.24 & 0.33 & 0.24 & 0.24 \\
\hline Hevonen - Horse .......... & 1.0 & - & 1.0 & - & 1.0 & - \\
\hline Lehmät - Cows ............. & 9.0 & 17.4 & 7.5 & 4.6 & 9.7 & 17.6 \\
\hline Ruohovasikat - Grass calves & - & - & 5.6 & - & 7.3 & - \\
\hline Teurasnaudat - Beef cattle ... & - & - & - & - & - & - \\
\hline Siat - Pigs .................. & - & 4.5 & 4.5 & 7.6 & 4.5 & - \\
\hline Lampaat - Sheep ......... & - & - & - & 95.3 & - & - \\
\hline Mäntypuu - Pine $80 \mathrm{P} \ldots$. & 79.2 & 0.84 & 79.1 & 75.4 & 35.9 & 5.1 \\
\hline,$\quad 100 \mathrm{P} \ldots$ & - & - & - & - & - & - \\
\hline , $130 \mathrm{P} \ldots$. & - & - & - & - & - & - \\
\hline , 100 PH... & - & - & - & - & - & - \\
\hline, 130 PH... & - & - & - & - & - & - \\
\hline Suo-ojitukset - Peat drain ... & - & - & - & - & - & - \\
\hline $\begin{array}{l}\text { Rehuviljan ostot, ry ............ } \\
\text { Purchases of feed grain, fu }\end{array}$ & 2719 & - & 3655 & - & 5833 & - \\
\hline
\end{tabular}

Viikottaisen työajan rajoittaminen työaikalain mukaan 40 tuntiin, kuitenkin siten, että niitä ei suoranaisesti sovelleta kiirekausina, alentaa luonnollisesti katetuottoa. Vähennykset vaihtelevat $860-3500 \mathrm{mk}$ välillä todella vallinneissa hintasuhteissa. Metsä jää miltei kokonaan pois tekn. II:n vaihtoehdoissa, joissa maidon hinta vastaa todella vallinnutta tasoa (Taulukko 20$)$. 


\section{Yhteenvetoa ja päätelmiä}

Kainuulaisia uudistiloja koskevat LP-laskelmat ovat edellisen mukaisesti johtaneet siihen tulokseen, että traktoritekniikan omaksuminen vallitsevissa olosuhteissa johtaa viljelijäperheen työvoiman tehokkaampaan ja tuottavampaan hyväksikäyttöön, kuin hevostekniikka, joskin kummankin tekniikan yhdistäminen tilojen keskeisellä yhteistyöllä parantaisi tässä ainakin hevostilojen tuloksia. Viljelyaloja erityisesti turvemailla kannattaa laajentaa ja lypsylehmien lukua lisätä, jolloin päästään korkeampaan katetuottoon. Ruohovasikan mukaanottaminen tuotantosuunnitelmaan ei vuosien $1959-63$ hintatason mukaan ollut kannattavaa, mutta v. 1972 hintojen mukaan niillä voidaan hevostilojen katetuottoa kohottaa. Traktoritekniikan omaksuneet tilat voivat edullisesti laajentaa viljelyalansa $20-22$ ha:iin ja pitää n. 18 lehmää, mikä kyllä edellyttää nykyistä suurempia navetoita ja navettatyön ainakin osittaista koneistamista. Sika voisi tulla tuotantosuunnitelmaan lähinnä silloin, jos sianlihan hinnat suhteessa maidon ja viljan hintoihin olisivat edullisempia. Lampaanpidon kannattavuus ei ole ollut riittävän hyvä, että se olisi voinut tulla maidontuotannon kanssa kilpailukykyiseksi vallinneissa hintasuhteissa.

Edullisimman tuotantosuunnitelman mukaan kannattaa kivennäismailla oleva metsä, jonka enimmäisala on tässä rajoitettu 80 hehtaariin, hoitaa järkeviä metsänhoitotoimenpiteitä ja mm. harvennushakkuita suorittaen hyvin, ja työvoima riittää siihen. Ellei pinta-alarajoitusta olisi, tällaista metsää sisältyisi tuotantosuunnitelmaan enemmänkin. Turvemaan metsien hoito, senjälkeen kuin ne olisi saatettu tuottokuntoiseksi, lisäisi mahdollisuuksia laajentaa metsätalouden osuutta taloussuunnitelmassa. Turvemaalla esiintyvien metsättömien tai kitukasvuisten metsämaiden ojittaminen, vaikkapa vain ihmistyönäkin, on tulovaikutuksiltaan siksi kilpailukykyinen, että se erityisesti työvoiman täydellisempää hyväksikäyttöä edistäen tulee vuoden 1959-63 hintasuhteissa mukaan suunnitelmaan.

Puuston hakkuuarvon koron huomioonottaminen muuttuvana kustannuksena muuttaa metsätalouden järjestelyä lyhyen kiertoajan suuntaan ja vähentää metsätalouden suhteellista merkitystä.

Tutkimuksessa on tarkasteltu myöskin nurmen hehtaarisadon suuruuden vaikutusta edullisimpaan tuotantosuunnitelmaan. $10 \%$ :n lisäykset tai vähennykset sadossa tuntuivat n. 500-1000 markan lisäyksinä tai vähennyksinä katetuotossa ja eräinä muutoksina mm. metsätalouden työn käytössä.

Viikottaisen työajan rajoittaminen työaikalain mukaiseen 40 tuntiin, 
edellyttääen kuitenkin, että rajoituksia ei suoranaisesti sovelleta kiirekausina, alentaa katetuottoa eri tapauksissa 860 ja $3600 \mathrm{mk}$ välillä tilaa kohden. Metsätalous jää tällöin miltei kokonaan pois optimaalisesta tuotantosuunnitelmasta eräissä traktoritekniikan vaihtoehdoissa.

Jotta saataisiin kuva hintasuhteiden vaikutuksista, on suunnitelmissa otettu mukaan vaihtoehto, jossa maidon hinta olisi vastannut suunnilleen maailmanmarkkinoiden määräämää tasoa. Kuten oli odotettavissa, naudan-, sian- ja lampaanlihan tuotanto on tällöin tullut suuremmassa määrin mukaan, mutta katetuotot ovat olleet tuntuvasti alhaisempia.

Eri vaihtoehtoja verrattaessa on siis voitu huomata myöskin vallitsevien hintasuhteiden tuntuva vaikutus tuotannon edullisimpaan järjestelyyn. Valtion hintapolitiikalla on näihin ollut suuri vaikutus. Näyttää siltä, että Kainuun viljelijät ovat jotakuinkin hyvin pystyneet päättelemään, mikä tuotantosuunta vallitsevissa hintasuhteissa on kannattava. Kuten tutkimusaikana vallinnutta talousmuotoa tarkasteltaessa (.p 364) on käynyt ilmi, viljelijät ovat järjestäneet maataloustuotantonsa pääasiassa lypsykarjatalouteen perustuvaksi. 


\section{KIRJALLISUUSLUETTELO}

Aaltonen, V. T. 1935. Kasvatushakkuiden perusteista. Suomen Metsånhoitoyhd. Vuosik. 5: 85-103.

ANDERsson, S-O. 1963. Produktionstabeller för norrländska tallplanteringar. (Summary: Yield tables for plantations of Scotch pine in Northern Sweden). Medd. Statens Skogsforsk.inst. 51, 3. 337. p.

Aro, P. 1965. Puutavaran kuutioiminen. Tapion taskukirja, p. 253-272.

Beckmann, M. J. 1959. Lineare Planungsrechnung. 118 p. Ludwigshafen am Rhein.

Borgan, S. 1956. Profit maximizing plans and production stability in agriculture. An application of linear programming. 72 p. Iowa State College. Moniste.

BRUNnfäLt, G. 1952. Mjölkproduktionens säsongvariation med särskild hänsyn till dess inverkan på foderkostnader vid produktionen. $12+206$ p. Uppsala. Diss.

BRUUN, E. 1928. Lypsykauden maidontuotantokäyrään vaikuttavista tekijöistä ja sen muodon periytymisestä itäsuomalaisessa karjassa. (Summary: Factors influencing the lactation curve and heritabliness of its shape in East Finland cattle.) Valt. Maatal.koetoim. Julk. 18: 1-137.

CAJAnder, E. 1927. Ilmasto ja maatalous. 277 p. Porvoo.

CARbonnier, C. 1959. Gallringsförsök i naturbestånd av tall i Norrbottens län. Statens Skogsforskn.inst., Uppsatser 67: $367-385$.

DANø, S. 1957. Numerisk løsning av lineaere programmerings problemer ved Simplex-metoden. Univ. økon. lab. 25 p. København. Moniste.

Duerr, W. A. \& Bond, W. E. 1952. Optimum Stocking of a Selection Forest. Journal of Forestry 50: 12-16.

Edgren, W. \& NyLinder, P. 1950. Funktioner och tabeller för bestämning av avsmalning och formkvot under bark för tall och gran i norra och södra Sverige. Medd. Statens Skogsforsk. inst. $38,1: 1-81$.

Eklund, B., Nilsson, Hj., Carlsson, G. \& Hellström, P. 1946. Arbetsledaren. 387 p. Stockholm.

Elsner, K. 1964. Mehrstufige Produktionstheorie und dynamisches Programmieren. Schriften zur wirtschaftswissensschaftlichen Forschung 11: 1-162. Meisenheim am Glan.

Elstrand, E. 1965. Lineaer programmering ved hjelp av EDB-maskiner. Norges Landbr. økon. Inst. 42 p. Moniste.

Finnish Study Group. 1969. Comparative Advantage or Disadvantage of Land Clearing. Helsingin Yliop. maatal.polit. lait. Moniste 16. p. $163+$ liitt.

Foor, A. S. \& Line, C. 1966. The consumption of hay and grass silage by Friesian milking heifers on high and low intakes of concentrates. X Intern. Grassld Congr., Section 2: 238-241.

Gordon, C. H., Derbyshire, J. C., Alexander, C. W. \& Mccloud, D. E. 1966. Effects of grazing pressure on the performance of dairy cattle and pastures. X Intern. Grassld Congr., Section 2: 120-125.

Hakkarainen, E. J. 1966. Naudanlihan hintojen kausivaihtelut ja tuotaninon edullisin järjestely. Helsingin Yliop. Maatal.polit. lait. 156 p. Laudaturtyö.

Harve, P. 1940. Puutavaran kantohinnat 5-vuotiskautena 1934-39. Metsätal. Aikak. 1. Erip. 8 p. Helsinki. 
Heady, E. O. \& Candler, W. 1960. Linear Programming Methods. IX + 597 p. Ames, Iowa. Heikinheimo, L., KuUsela, K. \& Sivonen, S. 1967. Metsätalouden hinta-, kustannus- ja kannattavuusarvio. Suomen Pankin Taloustiet. Tutk.lait. Julk. C 5: 1-70.

Heikurainen, L. 1959. Tutkimus metsäojitusalueiden tilasta ja puustosta. (Ref: Úber waldbaulich entwässerte Flächen und ihre Waldbestände in Finnland.) Acta For. Fenn. 69: $1-297$.

_, 1961. Metsäojituksen vaikutuksesta puuston kasvuun ja poistumaan. (Summary: The influence of forest drainage on growth and removal in Finland.) Acta For. Fenn. 71, 8: $1-71$.

— - 1964. Suotyyppien ojituskelpoisuus metsänkasvatusta silmällä pitäen. 47 p. Helsinki.

- - Keltikangas, M. \& SeppäLÃ, K. 1965. Kustannusten jakaminen yhteisissä metsäojitushankkeissa. (Summary: Allocation of costs in joint forest drainage undertakings.) Silva Fennica 115: 1-39.

Heiskanen, V. 1965. Sahateollisuus puun käyttäjänä. Tapion Taskukirja 1965, p. 383-395. Helsinki.

HJortshøj-Nielsen, A. 1964. Anvendelse af lineaer programmering i landbrugets produktionsøkonomi. Den Kgl. Veter. - og Landbohøjsk., Afd. før landbrugsøkon. 98 p. København. Mimeo.

Huikari, O. 1961. Metsänhoitotöiden työnmenekkilaskelman perusteet. Silva Fennica 110: $184-189$.

HyppöLÄ, K. \& Hasunen, O. 1970. Dry matter and energy standards for dairy cows. Acta Agr. Fenn. 116, 1: 1-59.

Håndbog for Driftsplanlaegning. 1966. Landbr.min. Driftsøkon. udvalg. 138 p. København.

Ilvessalo, Y. 1937. Perä-Pohjolan luonnonnormaalien metsiköiden kasvu ja kehitys. (Summary: Growth of natural normal stands in Central North Suomi (Finland). Metsätutk.lait. Julk. 24, 2: 1-168.

- - 1952. Metsikön kasvun ja poistuman välisestä suhteesta. Metsäntutk.lait. Julk. 40, 1: $1-29$.

— - 1957. Suomen metsät metsänhoitolautakuntien toiminta-alueittain. Valtakunnan metsien inventoinnin tuloksia. (Summary: The forests of Finland by forestry board districts. Results of national forest inventory.) Metsäntutk.lait. Julk. 47, 3: 1-128.

- - 1967. Luonnonnormaalien metsiköiden kehityksestä Kainuussa ja sen lähiympäristőssä. (Summary: On the development of natural normal forest stands in south-eastern NorthFinland.) Acta For. Fenn. 81, 5: 1-85.

JÄrvi, V. 1967. Laiduntarkkailu kertoo. Pellervo 68, 4: 202-203.

JĀĀSKELĀINEN, O. 1936. Tutkimuksia länsisuomenrotuisen ja ayrshirerotuisen nuoren karjan kasvusta ja rehunkäytöstä. (Ref: Untersuchungen über den Zuwachs und Futterverbrauch des westfinnischen und des Ayrshire-jungviehs.) Acta Agr. Fenn. 33: 1-112.

KAJANojA, P. \& LARPES, E. 1962. Lihanaudan kasvatuskokeesta vuosina 1960-61.(Summary: Feeding trial on calves intended for meat production.) Maatal. ja Koetoim. 16: 179-184.

KAlelA, E. K. 1961. Metsiköiden kunnostaminen. 58 p. Helsinki.

KALlıo, K. 1957. Käenkaali-mustikkatyypin kuusikoiden kehityksestä Suomen lounaisosassa. (Summary: On the development of spruce forests of the Oxalis-Myrtillus site type in the South-West of Finland.) Acta For. Fenn. 66: 1-155.

KERĀNEN, J. 1942. Lämpötalous ja lämpötila maatalousilmastollisina tekijöinä Suomessa. (Ref: Wärmehaushalt und Temperatur als agrarklimatologische Faktoren in Finnland.) Terra 54: 1-2.

KILKKI, P. \& VÄISÄNEN, U. 1969. Determination of the optimum cutting policy for the forest stand by means of dynamic programming. Acta For. Fenn. 102: 1-23.

Korvisto, E. \& YLISELÄ, P. 1964. Eri ikäisten nautojen teuraspainoista (Zusammenfassung: Uber die Schlachtgewichte verschiedenalteriger Rinder.) Pellervo-Seuran Markk.tutk. lait. Julk. 7: 1-28.

Korvisto, P. 1959. Kasvu- ja tuottotaulukoita. Metsäntutk.lait. Julk. 51, 8: 1-49.

Korhonen, V. V. 1958 a. Lumi ja jääsuhteet. Oma maa I, 3 p., p. 132-146. Helsinki.

- 1958 b. Suomen ilmasto. Oma maa I, 3 p., p. 339-354. Helsinki. 
KURKI, M. 1963. Suomen peltojen viljavuudesta vuosina 1935-1960. Viljavuuspalvelu Oy:ssä tehtyjen tutkimusten perusteella. (Referat: Uber die Fruchtbarkeit des finnischen Ackerbodens auf Grund der in den Jahren 1955-1960 durchgeführten Bodenfruchtbarkeitsuntersuchungen.) 107 p. Helsinki.

KuUselA, K. \& Nyyssönen, A. 1962. Tavoitehakkuulaskelma. (Summary: The cutting budget for a desirable growing stock.) Acta For. Fenn. 74: 1-34.

LAsolA, T, 1965. Peltokasvien sadoista ja satomääriin vaikuttaneista tekijöistä ns. kylmillä asutustiloilla v. 1959-1963. (Summary: On the crop yields and some factors affecting these on s.c. cold farms, 1959-1963.) Acta Agr. Fenn. 106: 1-168 + XXII.

LEDJE, I. 1963. Jord- och skogsbruksföretagets planering. Medd. från ekon. inst. Lantbr. högsk. 126 p. Uppsala, Mimeo.

Lrhtonen, V. 1943. Tutkimuksia metsän puuston muodostumisesta. Tuottohakkauslaskelma. Acta For. Fenn. 51: 1-235.

Lindgren, J. E. \& NÄslund, B, 1968. Planering inom skogsbruket med användande av matematisk programmering. 146 p. Stockholm.

Linnamies, O. 1959. Valtion metsät sekä niiden hoidon ja käytön yleissuunnitelma. Vuosien 1951 - 55 inventoinnin tuloksia. (Summary: The State forests of Finland and a general management plan for them based upon an inventory made in 1951-55.) Acta For. Fenn. 68, 5: 1-225.

Maatalouden Tutkimuskeskus, Perä-Pohjolan koeasema. Koetuloksia vuodelta 1962, 1963, 1964. Moniste.

Maatalouskalenteri 1966. 384 p. Helsinki.

MaKкоNen, O. Minimiläpimitan vaikutus havupuiden valmistusaikaan. (Summary: Effect of minimum diameter on pulpwood preparation time.) Metsäntutk.lait. Julk. 63, 3: 1-34.

Malmborg, G. v. 1963. Economic Planning in Farm Forestry. A Study of the Fundamentals, the Application and Consequences with Respect to the Individual Enterprise and Society. 179 p. Stockholm.

Maunu, L. 1966. Puiset tuorerehutornit. Käytännön Maamies 1966, p. 240-242.

Metsätyőpalkkojen taulukot, palkkausalue 2. 1961. 34 p.

MYllylä, M. 1960. Parsinavetta ja pihatto ihmistyön kannalta. Työtehoseuran tutk. Koetoim. ja Käyt. 17, 3: 10 .

- 1963. Tilakohtaiset urakkatyöperusteet 1963. Heinien seipäillepano. Koneviesti 11, 13: 24 .

MÄKELÄ, A. 1956. Studies on the question of bulk in the nutrition of farm animals with special reference to cattle. Suomen Maatal.tiet. Seuran Julk. 85: 1-139.

Nordenborg, M. O. 1939. Lantbrukets arbetslära. 140 p. Stockholm.

NordFeldt, S. 1966. Utilization of hay and/or silage by dairy cows. X Intern. Grassld Congr. Section 2: $241-247$.

NYYSSÖNEN, A. 1954. Hakkauksilla käsiteltyjen männiköiden rakenteesta ja kehityksestä. (Summary: On the structure and development of Finnish pine stands treated with different cuttings.) Acta For. Fenn. 60: 1-194.

— - 1958. Kiertoaika ja sen määrittäminen. (Summary: Rotation and its determination.) Metsäntutk.lait. Julk. 49, 6: 1-87.

- - 1965. Metsän arvioiminen. Tapion taskukirja, p. 173-206.

NÄSLUND, M. \& HAGBERG, E. 1952. Skogsforskningsinstitutets större tabeller för kubering av stående träd. Tall, gran och björk i norra Sverige. 153 p. Stockholm.

Osara, N. A. 1948. Maatilametsälön taloussuunnitelma. 69 p. Helsinki.

Palohermo, L. 1956. Kotieläinhoidon perusteita 3 p. 621 p. Jyväskylä.

Pellervon Kalenteri 1961. 320 p. Helsinki.

Pessi, Y. 1965. Agriculture in Northern Fennoscandia. III. Acta Agr. Scand. Suppl. 13: $1-192$.

Petterson, H. 1937. Utvecklingsprognoser för skogsbestånd. Nord. Skogskongr., exk. 2: $4-31$.

- - 1955. Barrskogens volymproduktion. Medd. från Statens Skogsforsk.inst. 45, 1: 1-391.

_ - 1963. Barrskogens värdeproduktion. (Summary: Yield Value of Coniferous Forests.) Medd. från Statens Skogsforsk.inst. 52, 1: 1-510. 
Prhкala, K. U. 1968. On the optimum size and combination of enterprises on a North Finland pioneer farm. XIV. CIOSTA-Conf. 14 p. Mimeo.

Ронјакаllio, O. 1933. Viljelysmaiden lannoitus Suomessa lannoituskokeiden valossa. Valt. Maatal.koetoim. Julk. 53: 1-265.

PoIJÄrvi, I. 1927. Suomaalla ja kovalla maalla kasvaneiden heinien tuotantoarvo toisiinsa verrattuna. (Summary: Comparison of the productive values of hays from meadows on mineral and peat soils.) Valt. Maatal.koetoim. Julk. 13: 1-64.

- - 1941. Ruokinnan runsauden vaikutuksesta kotimaisen nuorenkarjan kehitykseen ja myöhempään tuotantoon. Valt. Maatal.koetoim. Tiedonant. 182: 1-23.

— - 1955. Korjuuajan, -tavan ja säiden vaikutus nurmesta saadun rehusadon määrään ja ravintoarvoon. Maatal. ja Koetoim. 9: 197-211.

PUUSTJÄRvi, V. 1959. Eri boniteettiluokkien ja suotyyppien tuottokyvystä paikalliskokeiden antamien tulosten valossa. (Summary: On the productivity of the different degrees of land quality, and bog types, in the light of results produced by local experiments.)

Suo 11, 5-6: 86-91.

- 1960. Pohjois-Suomen soista ja niiden tuottokyvystä etelän soihin verrattuna. (Summary: On the bogs in North Finland and their productivity as compared with bogs in the South.) Suo 11, 2: 28-29.

Raup, P. M. 1967. Land Reform and Agricultural Development. Agricultural Development and Economic Growth. XV +608 p. Ithaca.

RENBoRg, U. 1957. Lineär planering (linear programming) använd i lantbruksekonomiska driftsplaneringsproblem. 61 p. Stockholm.

Rrihinen, P. 1967. Cost Studies in European Forestry. 5. Finland. Studia For. Suecica, 49: $197-223$.

RoNGE, E. W. 1928. Kort redogörelse för vissa skogliga försök, verkställda under åren 19141928 å Kramfors Aktiebolags skogar och resultatens praktiska tillämpning i skogsbruket. Norrlands Skogsvårdsförb. Tidskr. 1928, p. 308-356.

RYYNÄNEN, V. 1969. Lammastalouden kannattavuudesta Helsingin yliopiston Malminkartanon tilalla. Maatal.tiet. Aikak. 41, 2: 105-122.

Salminen, M. 1964. Kokemuksia ja havaintoja nuoren naudan tuottamisesta nurmirehulla. (Zusammenfassung: Erfahrungen und Beobachtungen über Produktion von jungem Rind mittels Grasfuttermitteln.) Maatal. ja Koetoim. 18: 262-269.

SALONEN, M. 1963. Kiinteillä koekentillä suoritettujen uudismaan lannoituskokeiden tuloksia. (Summary: On the fertilization of newly reclaimed land.) Maatal. ja Koetoim. 17: 44-59.

- - TArnio, A. 1957. Fosforilannoitusta koskevia tutkimuksia. (Summary: Results of field experiments with different amounts of phosphate fertilizers.) Valt. Maatal.koetoim. Julk. 164: 1-104.

- - TArnio, A. 1961. Kalilannoitusta koskevia tutkimuksia. (Summary: Investigations on potash fertilization.) Valt. Maatal.koetoim. Julk. 185: 1-60.

- - TArnio, A. \& TÄhtrnen, H. 1962. Typpilannoitusta koskevia tutkimuksia. (Summary: Investigations on nitrogen fertilization.) Ann. Agric. Fenn., 1: 133-174.

Schneider, E. 1934. Theorie der Produktion. 92 p. Wien.

SIPILÃ, M. 1946. Maatalouden työajan käyttö ja työntutkimus. (Summary: Utilization of Working Hours and Efficiency Study in Agriculture.) Acta Agric. Fenn. 66: 1-496 + liitt. Diss.

SIrÉn, G. 1956. Männikön harvennuksesta. Metsätal. Aikak. 73 (19), 11: 40-49.

Skogsstatistisk Årsbok. 1960, 1963/64. Stockholm.

SorNı, S. 1966. Paikallisten lannoituskokeiden heinäsatoihin vaikuttavista tekijöistä. Ann. Agric. Fenn. 5: 185-206.

SVT (Suomen virallinen tilasto) III: 54. Maatalous, yleinen maatalouslaskenta 1959.

TrHoNen, P. 1965. Suomen pohjoispuoliskon metsien rakenne kehitysluokittain vuosina 196263. (Summary: The structure of forests in the northern half of Finland in the development classes in 1962-63.) Metsäntutk.lait. Julk. 62, 3: 1-34.

TSMK (Tutkimuksia Suomen maatalouden kannattavuudesta.) Tiliv. 1961-62. Maatal. Tal. Tutk.lait. Julk. 5: 1-67. 
TURккі, A. 1970. Nurmisäilörehun valmistuksen kustannuksista ja voimaperäisesti viljeltyjen nurminata- ja koiranheinävaltaisten säilörehunurmien taloudellisuudesta. Helsingin Yliop. Maanvilj.tal. lait. 124 p. +8 liitetaul. Laudaturtyö.

voN URFF, W. 1964. Produktionsplanung in der Landwirtschaft. Frankfurter Wirt. - und Sozialwiss. Studien 11: $1-318$.

Valmari, A. 1956. Uber die edaphische Bonität von Mooren Nordfinnlands. (Selostus: Pohjois-Suomen soiden maaperäboniteetista.) Acta Agr. Fenn. 88, 1:1-126.

- - 1957. Soiden jyvityksestä. (Ref.: Über die wirtschaftliche Bonitierung der Moore.) Acta Agr. Fenn. 88, 2: 1-87.

Wellman, U. 1966. A comparison of the dry-matter intake of silage and hay by cattle. X. Intern. Grassld Congr., Section 2: 222-224.

WEsterberg, T. \& LeVÄNEN, O. 1964. Lautamuotilla valetun rehusäiliön tarveaine- ja kustannuslaskelma v. 1964. Käytännön Maamies 40: 142-145, 173-177.

Westermarck, N. \& Mattil. A, L. 1969. Maatilasuunnittelun normikirja. $326+11$ p. Helsinki. — - Melén, A. 1962. Praktisk Driftsplanläggning. Sv. Lantbr. sällsk. Förb. B 28: 1-153.

Wiksten, Å. 1961. Beskrivning och analys av några fasta gallringsförsök i mellersta Norrland. Tall (Pinus Silvestris L.) (Summary: Description and analysis of some thinning experiences in Central North Sweden. Scotch pine (Pinus Silvestris L.) Medd. från Statens Skogsforsk.inst. 49, 6: 1-63.

Virtanen, A. I. 1943. AIV-järjestelmä karjanruokinnan perustana. 300 p. Helsinki.

Vitting-Andersen, H. 1966. Efficiency in Dairy Farming in Different Environments (Denmark). X. Intern. Grassld. Congr. Mimeo.

VуокгцA, Y. 1956. Etelä-Suomen hoidettujen kuusikoiden kehityksestä. (Summary. On the development of managed spruce stands in S.F.) Metsäntutk.lait. Julk. 48, 1: 1-138 s.

— - 1969. Harvennusmenetelmät ja harvennusmetsiköt etenkin koneellisen puunkorjuun kannalta. 147 p. Helsinki.

VUoRIsTo, I. 1937. Tyỏaikatutkimuksia kuusipaperipuiden teosta. (Summary: Investigations regarding the working time in the preparation of spruce pulp-wood.) Communicationes Instituti Forestalis Fenniae 23: 1-146.

Väkilannoitteet maataloutemme kohottajina. 1955. Pellervo-Seura. 263 p. Helsinki.

ZAPF, R. 1965. Zur Anwendung der linearen Optimierung in der landwirtschaftlichen Betriebsplanung. Ber. über Landw. Neue Folge. 179: 1-102. 


\section{SUMMARY}

\section{On the optimum size and combination of agricultural and forestal activities of a typical North-East Finland pioneer farm.}

The aim of the study is to outline how the land resources in a typical region in NorthEast Finland should be allocated for agricultural and forest production within the framework of a family farm established on forest and peat land. The study is part of a study project initiated by a fellowship from the YRJÖ JAHNSson Foundation and subsequently financed by the US Dept. of Agriculture, according to US Public Law 480. The empirical data for the study are partly based on the records kept on twenty pioneer farms in the Suomussalmi commune on the eastern boundary line of Finland, about $65^{\circ}$ Lat., $200 \mathrm{~m}$ above the sea level. In the calculations of the various alternatives, some results of agronomic and forest experimental research on the same or nearby regions are also utilized,

It has been presumed that the land would be used both in agriculture and in forestry up to an intensity level that would produce the highest gross margin level for the farmer himself and for his wife, who would use half of her available work time in agriculture (care of animals and field work when necessary). There would be an opportunity to have the help of a third family member during peak periods in the summer against a moderate payment. Two levels of techniques are assumed, one based on the use of a draft horse and respective implements, the other on the use of a $35 \mathrm{HP}$ tractor with appropriate own machines. The use of a combine, forage harvester and manure spreader, is also assumed, but only against payment covering the costs of cooperative use.

The average peat soils in North-East Finland need a liberal use of nitrogen fertilizers in order to give satisfactory crops of hay. Only the very best may give $3000-4000 \mathrm{~kg}$ without fertilizing. The farms in the study area have used rather heavy doses of artificial fertilizers.

A still heavier use of especially nitrogen fertilizers on timothy and meadow fescue leys is recommended by some researchers, who stress the increase of yields and crude protein content of the grass. The use of grass silage, which is not common in the study area, should be introduced in the opinion of certain research workers.

Utilizing the results of two series of three-year fertilizing experiments on grassland, established on average quality peat soil at Rovaniemi Experimental Station, Apukka $\left(67^{\circ}\right.$ Lat.), calculations of the variable costs of fodder units produced on four or five different levels of fertilizers, chemicals used in conserving and costs of silo and forage harvester were taken into account. The estimated variable cost of the working horse and tractor, estimated per used working time ( 0.25 resp. 1.85 per hour), as well as the cost of human labour, according to a preliminary estimate (2:- per working hour), were taken into account. The yields per hectare in fodder units and the quality indicators of the produced fodder units by different intensity levels are presented in Table 11, the total variable cost and its factor taking the two techniques into account, in Table 12.

The average yield on the study farms was $4200 \mathrm{~kg}$ (1680 f.u.) hay per hectare, grazing yield not included, while the use of $\mathrm{N}$ was $63.2 \mathrm{~kg}, \mathrm{P}_{2} \mathrm{O}_{5} 72.3 \mathrm{~kg}$ and $\mathrm{K}_{2} \mathrm{O} 94.4 \mathrm{~kg}$ per hectare in the whole field area. 
As milk production has been the main line in the region, it is anticipated that it will be included in the optimum plan. Taking into account its importance in utilizing the crops of grassland, some alternatives are assumed. The average milk yield of the North Finland milk recording herds is about $3200 \mathrm{~kg}$ per cow, with upper and lower limits of $3600 \mathrm{~kg}$ and $2800 \mathrm{~kg}$. These alternative production levels are taken under examination and a certain hypothesis is made about the shape of the lactation curve. The live weight of the animals is assumed to be $390 \mathrm{~kg}$ (the average of milk recording herds); the fat content of the milk 4.3 per cent (the average of milk deliveries to the local cooperative dairy).

The optimum feeding plan for the different alternatives of milk production per cow and the different alternatives of basic fodder, have been made using the Linear Programming method. The feeding plan meets the requirements of energy and digestible crude protein for every month, while the aconverted, dry matter content does not exceed $10 \mathrm{~kg}$ daily. In this calculation, suggested by recent research work (MÄKEL Ä 1956, HYPPöLÄ and HASUNeN 1970), the dry matter of concentrates and beets has accounted only for half the weight, as its addition to the ration is not limited to the same extent as the addition of dry matter of roughage. As to the concentrates, barley (price $32 \mathrm{p} / \mathrm{f} . \mathrm{u}$.) and a mixture of oil cakes and barley (1: 3 , price $37.7 \mathrm{p} / \mathrm{f} . \mathrm{u}$.) are taken into account. As milk production during the pasture period has been about $13 \%$ higher than average, the feeding plan has been made assuming the respective timing of this period.

The minimum cost combination of fodders, calculated by computer, is presented in Table 13. The preliminary cost estimates are also given. For comparison the actual use of fodder on the study farms keeping records is presented in Table 10.

The returns and variable costs of keeping milk cows, not including labour and home pro) iced seed, are presented in the tabulation on p. 404. The use of labour was estimated at 23p, 240 or 250 hours, depending on the production level.

Complementary to the milk production, rearing of beef calves or pigs are taken as alternatives. When the milk has been used for butter production, the returned skim milk is sufficient for 3.9 calves raised to e.g. 8-9 months, or 7.2 pigs, assuming the $3600 \mathrm{~kg}$ alternative milk production. Three alternative plans for beef production are assumed, one up to $120 \mathrm{~kg}$ slaughter weight in 10 months, another to $110 \mathrm{~kg}$ in 8 months, another to $235 \mathrm{~kg}$ in 24 months using small amounts of skim milk and more grain, and a third to $167 \mathrm{~kg}$ in 19 months, with liberal use of skim milk, litle grain and an effective use of pasture during two seasons. Rearing pigs of a light type up to $78 \mathrm{~kg}$ slaughter weight, through the use of $400 \mathrm{~kg}$ skim milk and $320 \mathrm{~kg}$ barley. The work time for a 6 month old calf is estimated at 40 hours and for a one year old at 54 hours; the work time for a 6 months old pig is correspondingly 12 hours.

The raising of sheep, an old line of production in North-East Finland, is taken as an alternative. 1.8 surviving lambs per ewe, with an average slaughter weight of $11.5 \mathrm{~kg}$, is assumed; further, $5.25 \mathrm{~kg}$ mutton and $4.55 \mathrm{~kg}$ wool per ewe, making a gross return of 108:- per ewe according to the 1959-63 prices and 194:- according to the prices in 1972 . The care of sheep has been estimated to demand 10 hours per ewe. (There may be doubts on the thriving of sheep on peat land).

Barley as well as potato are taken into account in the computations. As there is a big difference in the prices of potato for human consumption and for feed, two alternatives are presented the first one with a limitation of 0.24 ha for direct consumption at a price of $23 \mathrm{p} / \mathrm{kg}$, the other without limitation priced at $6 \mathrm{p}$ for feed. The barley price has been quoted as $30 \mathrm{p}$, which accords with that used in the feeding calculations. The crop yield of barley has been $1700 \mathrm{~kg} / \mathrm{ha}$, on mineral soils and $1200 \mathrm{~kg} / \mathrm{ha}$ on peat soils, that of potato $15000 \mathrm{~kg} / \mathrm{ha}$ on mineral soil.

The forestry resources of the region consist of about one half of predominantly pine stands growing on mineral soils, while the other half are rather weak pine or spruce stands on swampy soils. The former show a growth about three times larger than the latter. About one fourth of the total area is waste land, almost exclusively open peat land which through appropriate reclamation could be taken either for agricultural or timber production. The cost of peat land draining for improved tree growth is about $90:-$, the reclamation for agricultural use is estimated to a cost of about 650:- using modern technics.

The forests of the region have a relatively larger than average proportion of old tree 
classes, and a sustained yield principle would involve a purposeful felling policy during a number of years. The calculations are, however, based on an assumption that approximately equal size and quality cuttings are possible from year to year on mineral soils, which today represent the only economically productive part of the forest area. A situation in which the drained forest land can be regarded as fully productive area is also envisaged.

In the calculations of the gross margin of forestry on mineral soil types, a recent investigation (Ilvessalo 1967) on the development of natural normal forest stands in the region of Kainuu, covering also the study area, is taken as a basis. One of the two most prevalent pine forest types in the region, the Empetrum-Vaccinium-Type (EVT), with a dominant height of $20.8 \mathrm{~m}$ at theage of 100 years, has been chosen as applicable for calculations, although it is the more productive of the two. The total growth within e.g. a 100 year rotation period is according to the investigation $2.8 \mathrm{cu} / \mathrm{m}$ per year. It is difficult to make a direct comparison with the forests of the study farms; the cutting plans for the latter are admittedly on the same level, but the prevalence of old classes as well as the occurrence of unproductive areas make comparisons doubtful. On the other hand, the natural stands where no thinning operations are effected, scarcely give the best results especially when sawn logs are produced.

The calculations are made taking into account the final cuttings only for rotation periods of 80,100 and 130 years. The intermediate and accretion cuttings within observed diameter classes are then estimated. The cutting of logs into lengths has been estimated following the so-called sutdragning method, applied by a Swedish scientist (PETTERson 1963). The stumpage prices are those obtained by study farms 1959-1963, whereby a certain gradation by dimension is presumed.

It is assumed that the pioneer farmers themselves perform the delivery cuttings and the hauling of the cut timber thereby earning an income. This income has been estimated on the basis of local tariffs negotiated between employers' and workers' organizations. The normal use of work time is estimated by dividing the piece rates by the time rates set as a target.

In the tabulation on p. 428 the volume data and valuation results of the EVT-type pine stands are presented. The stumpage prices are for $8^{\prime \prime}$ saw logs $-: 83,6$ per $\mathrm{f}^{3}$, and for pine pulp wood 2:55 per $\mathrm{m}^{3}$. The negotiated tariff for a lumberman was 15:60 and for a log hauler 36:-

An estimation is made, furthermore, of the yield value of drained, pine growing peat soils. Some recent research results have also been utilized here although this estimate is made independently. A rotation period of 90 years is assumed. (Cf. p. 433).

The forests of the study area had to a large extent belonged to the State or to corporations, and the farmers had until recent years had adequate opportunities to find employment here. What would be the optimum use of the farmers' own, mainly agricultural resources in the circumstances, may be an interesting subject for a separate study (Cf. Prhkala 1968). In this study, however, it is assumed that the land resources are owned exclusively by farmers, in which case some kind of a ceiling should be taken into account as there is at least a relative scarcity of land. If this ceiling is determined by dividing the area of Suomussalmi parish by the number of families belonging to the farm population, it would give approximately 80 hectares of mineral soil and 125 hectares of peat soil. Accordingly, the use of these maximum areas of both soil types is examined.

Further, there are the alternatives of the use of present and the future resources. Peat land, if used for forestry purposes, can be made productive only in the course of several decades. The labour used for improvements, such as draining, and on swampy forest land for intermediate cuttings in various stands, can be rated economical if the discounted value of future increase from sales of stump covers the direct costs and reasonable demands of the owner; as there is no liquid income, its value seems often hypothetical. It is difficult to make reliable estimates of such type of income.

Some efforts were made to estimate the discounted value of the future income expected from improvements where the requirement of working hours is determinable, and the respective activities are taken into account.

The first experiment with the LP-method in planning an optimum combination of activities was made using aggregated production processes. Thus the activities in milk production, and the alternatives where beef and pork were combined with milk, as well as an independent alternative, 
mutton, were all aggregated with grassland activities. The cultivation of barley and potato were taken as independent activities, producing for farm use or for market. The results of these calculations are shown in Tables 15 and 16.

These calculations were made also with the assumption that the drained forest land is already yielding an increased output.

The results of these calculations show that the pioneer farmers of the study area would, under the prevailing price conditions, be able to increase the gross margin of the farm by applying mechanized methods and by keeping cows with a higher milk production capacity. Beef and pig production were not competitive, neither was sheep, if the milk price was maintained at the level of the 1959-63 situation. Forest resources were fairly well utilized. The mechanized alternative gave, however, to some extent unrealistic results of the grain production. It is scarcely possible to cultivate barley for market as the quality of the grain is not competitive. On the other hand, the seasonal restrictions of forest work were not aptly chosen so that, there was much labour time unused according to these results.

In consequence new calculations were made using a disaggregated method, described among others by $\mathrm{Z}_{\mathrm{APF}}(1964,60-63)$. With regard to milk production calculations, the author's recommendations to take into account the diminishing work requirements of larger herds were followed. The final calculations were made using also capital restrictions, which referred only to variable capital (not land and existing buildings). Before the computer work, some corrections and alterations were made in the data, which reduce the comparability of the results of these calculations to those of the former ones.

The results of the disaggregated programme did not substantially deviate from those of the first calculations, if the economics of scale was not taken into account (Table 17). There was, however, rather a large variation especially in technique II, in the cultivated grassland area, as well as in the number of cows, if the diminishing work use per animal was included in the data. Thus, the optimum plan presumed a cultivated area of about 21 hectares, thereof 16 ha peat land and 17 cows, while the gross margin was increased by $4000 \mathrm{mk}$, to $16000 \mathrm{mk}$. The family labour is already fully utilized, and evidently an increase in agricultural production would be possible only by a simultaneous neglect of forestry work.

If the interest of the marketable value of standing timber is taken into accorount as a variable cost (Cf. Tables 19 and 20), only the shortest rotation period, 80 years, appears in the optimum plan. The gross margins will be lowered by $2100-2900 \mathrm{mk}$ in Techn. I, 1300-1900 in Techn. II, in the price levels of $1959-63$ and 1972 .

Some calculations were made, e.g. on the effects of varying grassland yields or of the recent legal restrictions of weekly working hours, if applied to a farm family (Cf. Table 20). The effects on the gross margin were in the former case approxim. $500-1000 \mathrm{mk}$ per farm, at a $10 \%$ change of yield, in the latter case $860-3500 \mathrm{mk}$, assuming a $40 \mathrm{hrs}$ week. The price relations, determined to a large extent by the Government price policy, have to some extent changed after the time when the field study was made. The calculations which were based on the prices of 1972 led however, to about the same structure of production, and it is interesting to note that the farmers have generally developed their production plans along the lines indicated in this study. 


\section{Liitteet}

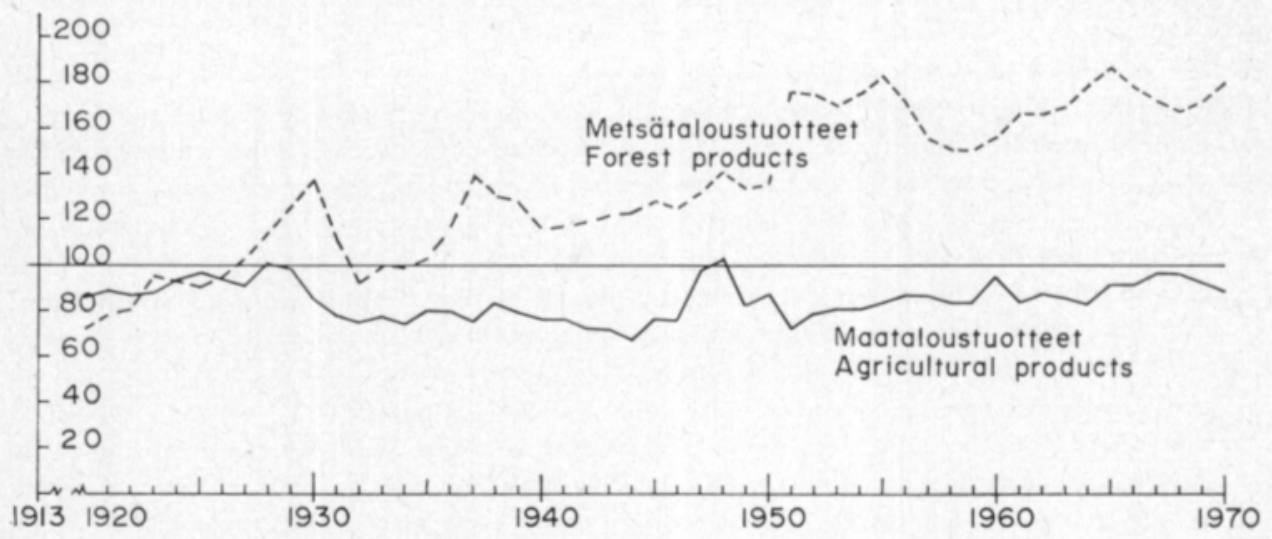

Liite 1. Maatalous- ja metsätaloustuotteiden suhteellisten tukkuhintojen kehitys 1920-1970 (Perusvuoden 1913 suhteelliset hinnat $=100$ ).

Appendix 1. Deflated indices of wholesale prices of agricultural and forest products in Finland.

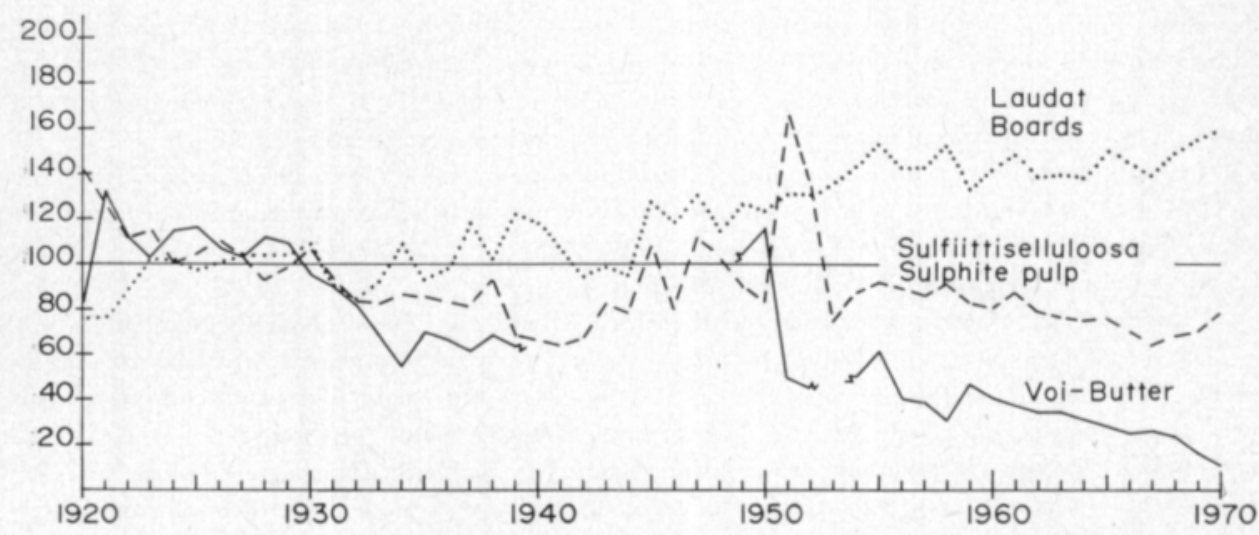

Liite 2. Eräiden tuotteiden suhteellisten vientihintojen kehitys $1920-1970 \quad(1913=100)$. Appendix 2. Trends of the deflated export prices of some products.

Appendix 3. Explanations to the abreviations used for soil types

Mineral soils:

$\mathrm{Mr}=$ Moraine soils

$\mathrm{HkMr}=$ Sand moraine soils

HHkMr $=$ Fine sand moraine soils

Hk = Sand soils

Swamp peat soils:

$\mathrm{BCt}=$ Bryales Carex peat

. $\mathrm{Ct}=$ Carex peat

LCt = Ligno Carex peat
LSCt = Ligno Sphagnum Carex peat

SCt = Sphagnum Carex peat

Bog peat soils:

$\mathrm{CSt}=$ Carex Sphagnum peat

LSt = Ligno Sphagnum peat

EuCSt $=$ Eutrophic Carex Sphagnum peat

ErSt $=$ Eriophorum Sphagnum peat

MSt = Ligno Sphagnum peat

St $=$ Sphagnum peat 